\title{
ROYAL POLIS POLICY IN THE SELEUKID HEARTLAND
}

by

Christopher Mark de L'isle

A thesis

submitted to Victoria University of Wellington

in fulfilment of the requirements for the degree of

Master of Arts

in Classics

VICTORIA UNIVERSITY OF WELLINGTON ANNO DOMINI NOSTRI MMXIII 



\begin{abstract}
In the Hellenistic Period most of the Greek poleis (city-states) came under the control of the Greco-Macedonian kings. The ideology of the poleis, which stressed the importance of autonomy, conflicted with the reality of royal domination. In Western Asia Minor, this conflict was resolved by presenting the relationship between king and polis as one of free association, in which the poleis were allowed a large amount of autonomy. The kings used ideas of reciprocity to tie the poleis to them and worked to make their rule as amenable as possible, while the poleis of Western Asia Minor continued to aspire to complete independence.
\end{abstract}

This was not the only possible resolution of the conflict between polis autonomy and royal dominance, however. In the Seleukid heartland of Syria and Mesopotamia the Seleukids founded and maintained new poleis. By means of names, myths, and symbols, the identities of these poleis were closely linked to the Seleukid dynasty. As a result, expressions of polis identity were expressions of loyalty to the dynasty, rather than of opposition. Their internal structures were based around an alliance between the royallyappointed epistates and the magistrates of the city, who represented a small civic elite. Royal support was thus important to the internal power structure of these poleis.

The poleis of the Seleukid heartland did not pursue full independence, even when the Seleukid royal power collapsed at the end of the Hellenistic period because, entirely unlike the poleis of Western Asia Minor, submission to a higher power was a central part of their identities and internal structures. 



\section{ANA@E $\Sigma I \Sigma$

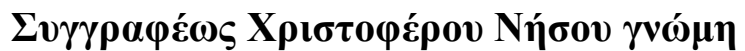

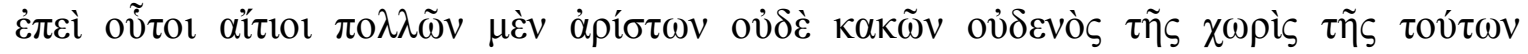
$\dot{\omega} \varphi \varepsilon ́ \lambda \varepsilon 1 \alpha \varsigma \dot{\alpha} \tau \varepsilon \lambda \varepsilon v \tau \eta \dot{\tau} \tau 0 v \tau \tilde{\eta} \sigma \delta \varepsilon \tau \tilde{\eta} \varsigma \theta \varepsilon ́ \sigma \varepsilon \omega \varsigma$,

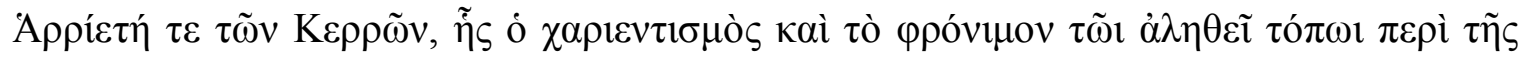

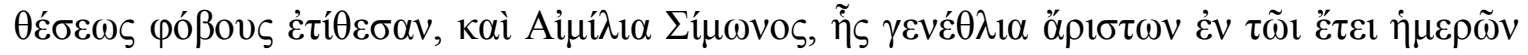

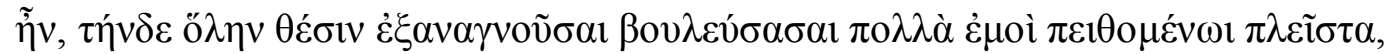

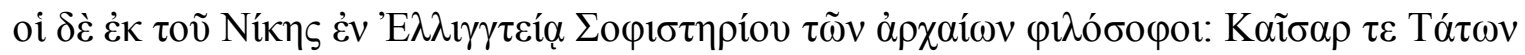

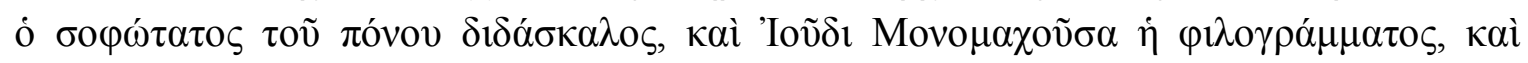

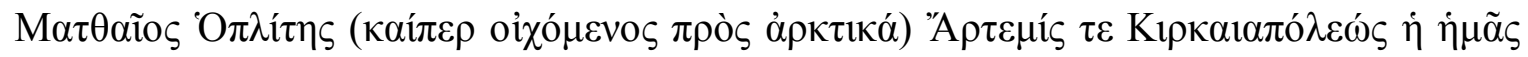

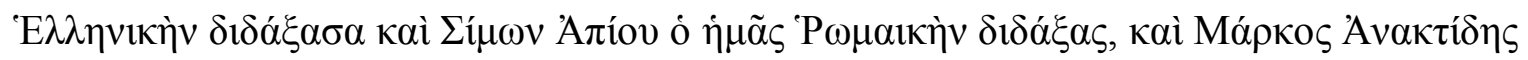

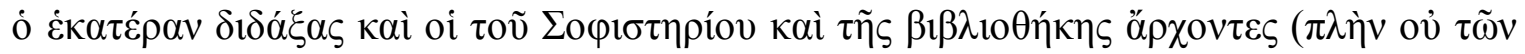

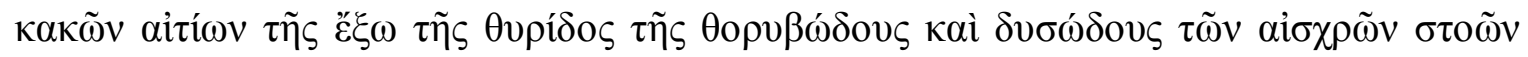

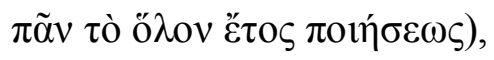

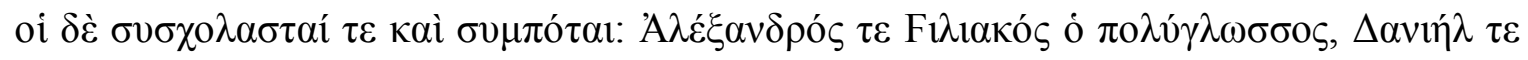

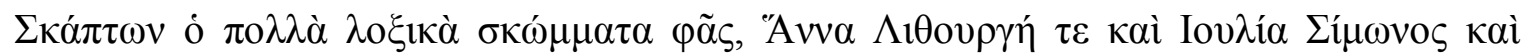

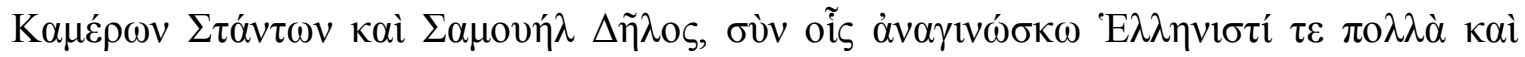
Р

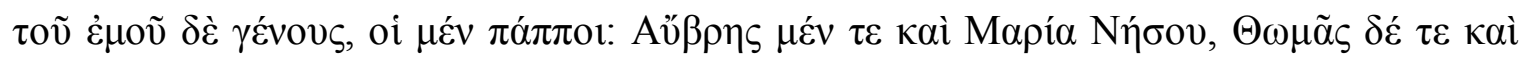

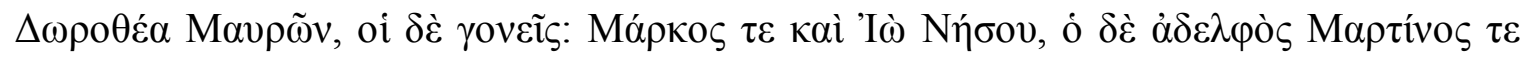

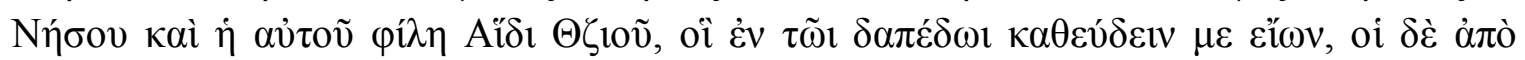

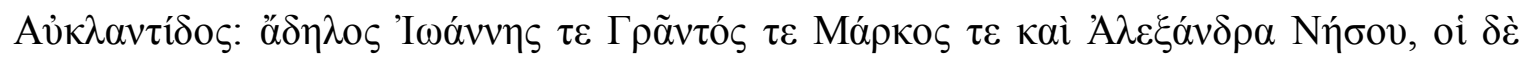

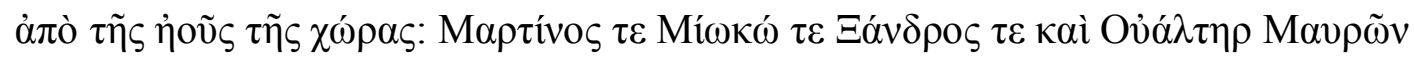

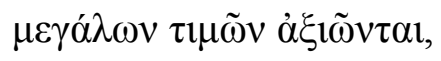

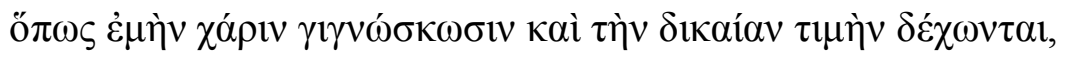

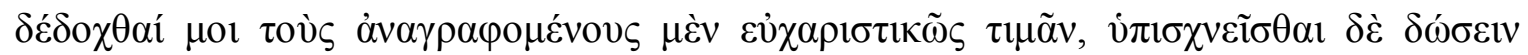

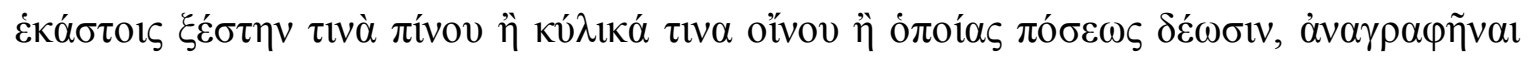

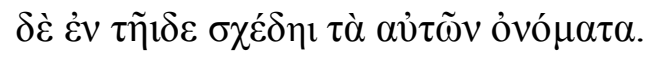

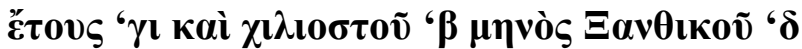





\section{CONTENTS}

Abbreviations: .viii

Figures:

One: Places Mentioned, Asia Minor................................................................. ix

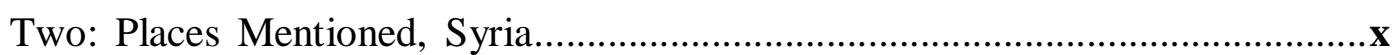

Three: Places Mentioned, Near East........................................xi

Four: Seleukid Genealogy............................................. xii

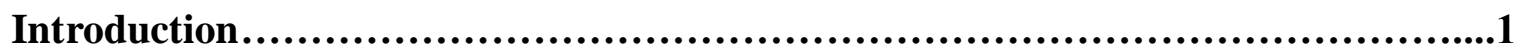

Chapter One: Kings and Cities in the Hellenistic Period..............................4

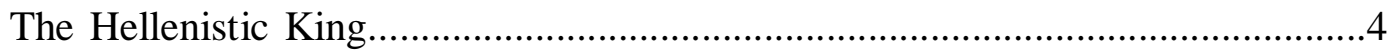

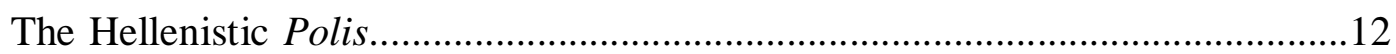

The Relationship between Kings and Poleis in Seleukid Asia Minor...................21

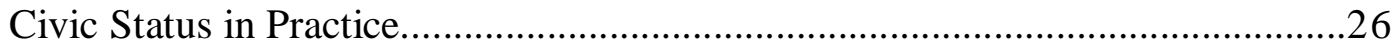

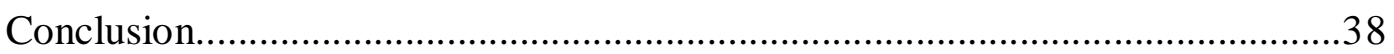

Chapter Two: The Seleukid Heartland \& Reasons for Colonisation..............................40

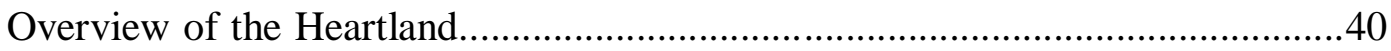

Were the Foundations of the Heartland Poleis?..................................................51

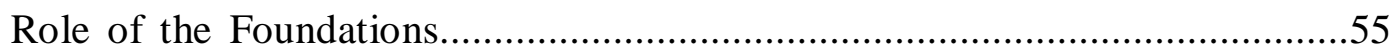

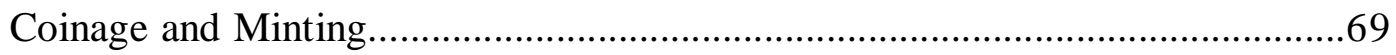

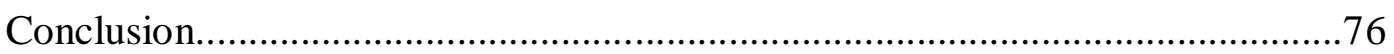

Chapter Three: The King \& His Poleis..........................................................................78

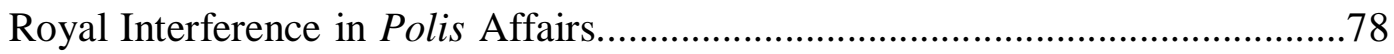

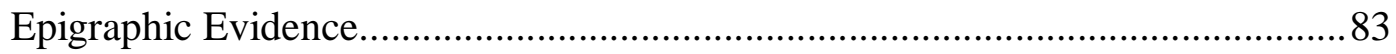

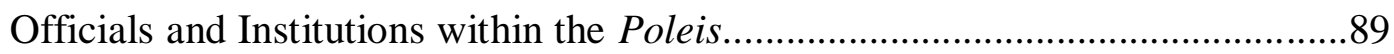

The End of the Seleukid Kingdom.....................................................................103

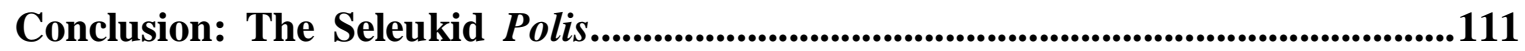

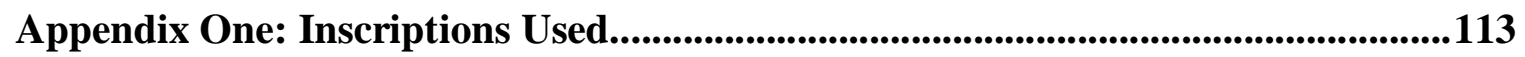

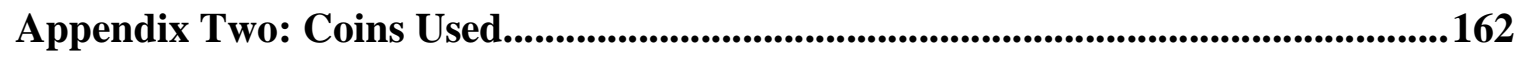

Bibliography :...........................................................................................................................................172 


\section{ABBREVIATIONS}

AD: Sachs \& Hermann Hunger. 1988. Astronomical Diaries and Related Texts from Babylonia. Vienna: Verlag der Österreichischen.

BCHP: Finkel I. \& R.J. van der Spek. Forthcoming. Babylonian Chronicles of the Hellenistic Period.

BMC: Gardner, Percy. 1878. A Catalogue of Greek Coins: The Seleukid Kings of Syria in the British Museum. London: British Museum Press.

ESM: Newell, Edward Theodore. 1938. The Coinage of the Eastern Seleucid Mints from Seleucus I to Antiochus III. New York, NY: American Numismatic Society.

F. Amyzon: Robert Jeanne \& Louis Robert. 1983. Fouilles d'Amyzon en Carie, I. Exploration, histoire, monnaies et inscriptions. Paris: De Boccard.

GCS: Wroth, Warwick William. 1899. Catalogue of the Greek Coins of Galatia, Cappadocia and Syria. London: British Museum Press.

Hefzibah: Landau, Y.H. 1966. "A Greek Inscription Found near Hefzibah.” Israel Exploration Journal 16(1): 54-70.

I. Erythrae: Engelmann, Helmut \& Reinhold Merkelbach. 1973. Die Inschriften von Erythrai und Klazomenai. Bonn: Rudolf Habelt Verlag.

I. Priene: Fredrich, C. et al. 1906. Inschriften von Priene. Berlin: Verlag von Georg Reimer.

IGLS: Jalabert, Louis, René Mouterde et al. 1870-1970. Inscriptions Grecques et Latines de la Syrie. Paris: Libraire Orientaliste Paul Geuthner.

Inscription d'Iran: Robert, Louis. 1949. "Inscriptions Séleucides de Phrygie et d'Iran." Hellenica 7: 5-29.

OGIS: Dittenberger, W. 1903-1905. Orientis Graeci Inscriptiones Selectae. Leipzig: Herzel.

P.Dura: Perkins, Ann. 1959. The Excavations at Dura-Europos: Final Report V Part I: Parchments and Papyri. New Haven, CT: Yale University Press.

$\boldsymbol{R C}$ : Welles, Charles Bradford. 1966. Royal Correspondence in the Hellenistic Period. Rome: "L’Erma" di Bretschneider.

SEG: Supplementum Epigraphicum Graecum.

SC: Houghton, Arthur \& Catharine Lorber. 2002. Seleucid Coins: A Comprehensive Guide. New York, NY: American Numismatic Society.

SdT: Le Rider, Georges. 1998. Séleucie du Tigre: Les Monnaies Séleucides et Parthes. Florence : Casa Editrice Le Lettere.

Syll ${ }^{3}$ : Dittenberger, W. 1915-1924. Sylloge Inscriptionum Graecarum. $3^{\text {rd }}$ Ed. Leipzig : Herzel.

WSM: Newell, Edward Theodore. 1941. The Coinage of the Western Seleucid Mints from Seleucus I to Antiochus III. New York, NY: American Numismatic Society.

All other abbreviations conform to those used by the $4^{\text {th }}$ edition of the Oxford Classical Dictionary. 


\section{FIGURE ONE: PLACES MENTIONED, ASIA MINOR}

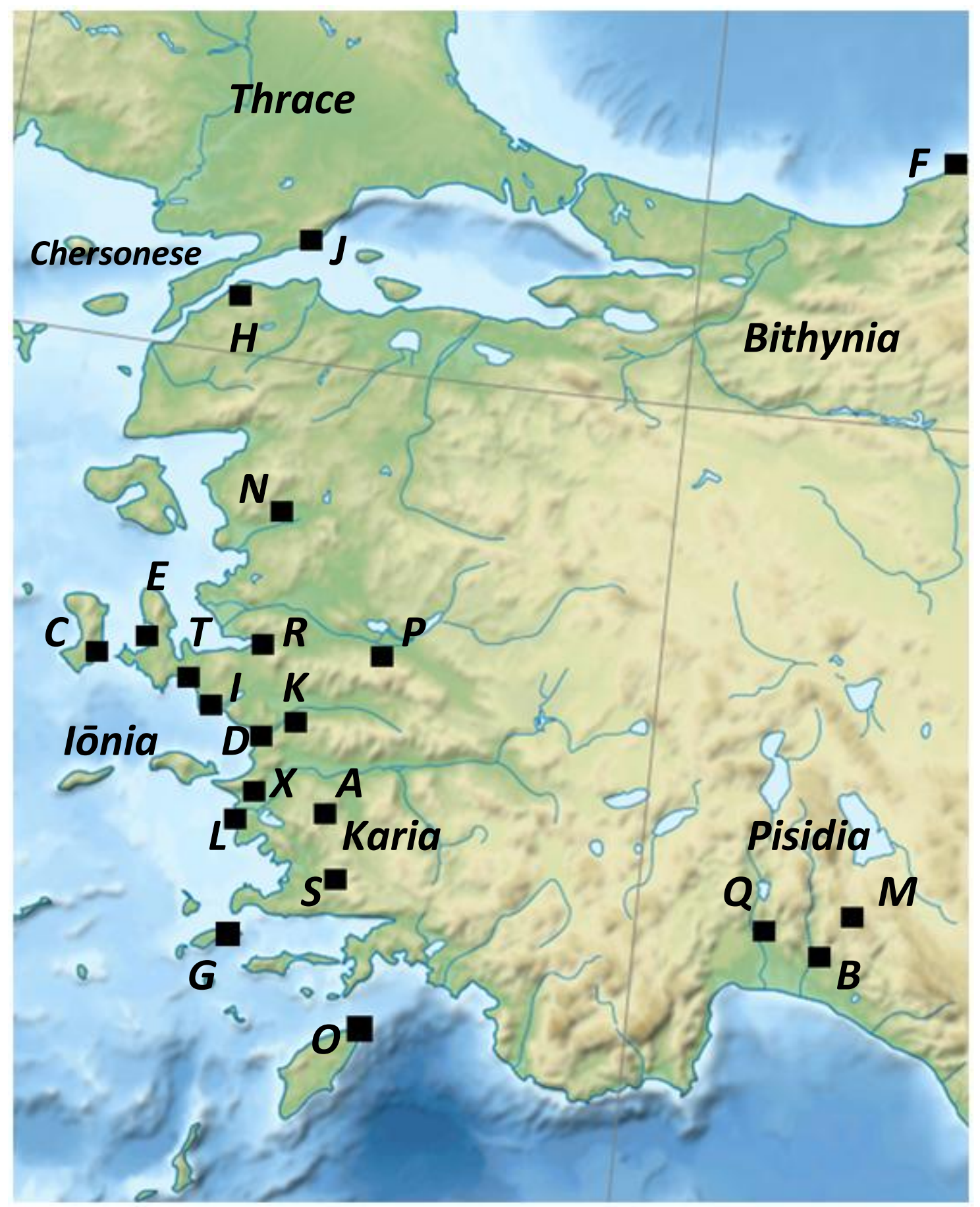

(base map sourced from http://commons.wikimedia.org/ Near_East_topographic_map-blank.svg)
A: Alabanda
B: Aspendos
C: Chios
D: Ephesos
E: Erythrai
F: Hērakleia Pontikē
G: Kōs

H: Lampsakos

I: Lebedos

J: Lysimacheia

K: Magnēsia

L: Milètos

M: Pednelissos

N: Pergamōn
X: Priēnē

O: Rhodes

P: Sardis

Q: Selgē

R: Smyrna

S: Stratonikeia

T: Teōs 


\section{FIGURE TWO: PLACES MENTIONED, SYRIA}

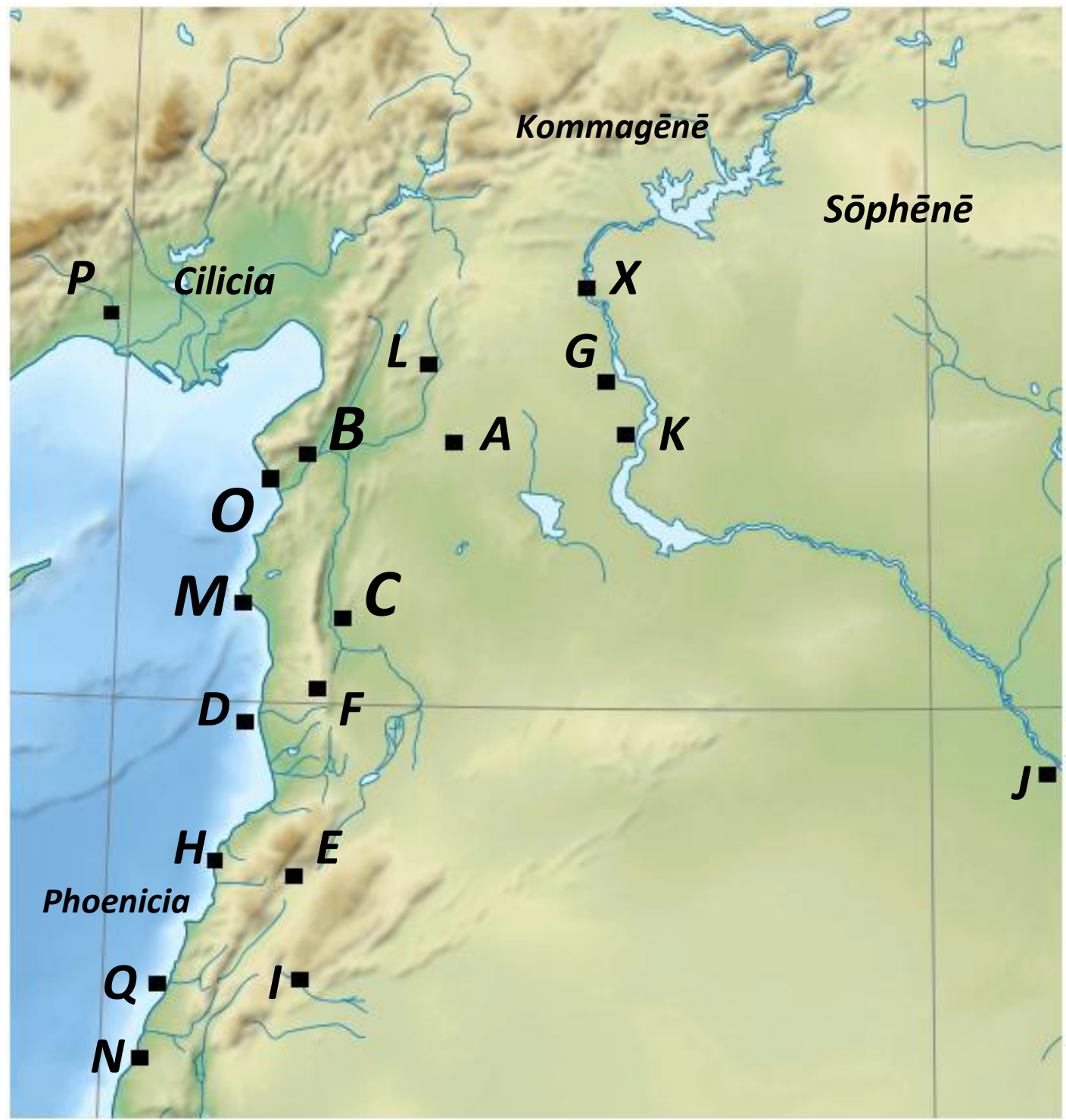

(Base map sourced from http://commons.wikimedia.org/wiki/File:Middle_East_topographic_map-blank.svg)
A: Aleppo (Beroia)
B: Antioch
C: Apameia
D: Arados
E: Baalbek
F: Baitokaikē

G: Bambykē

H: Byblos

I: Damascus

J: Doura-Eurōpos

K: Jebel-Khalid

L: Kyrrhos

M: Laodikeia-by-the-Sea

N: Ptolemais-Akē

X: Seleukeia Zeugma

O: Seleukeia-in-Pieria

P: Tarsos

Q: Tyre 


\section{FIGURE THREE: PLACES MENTIONED, NEAR EAST}

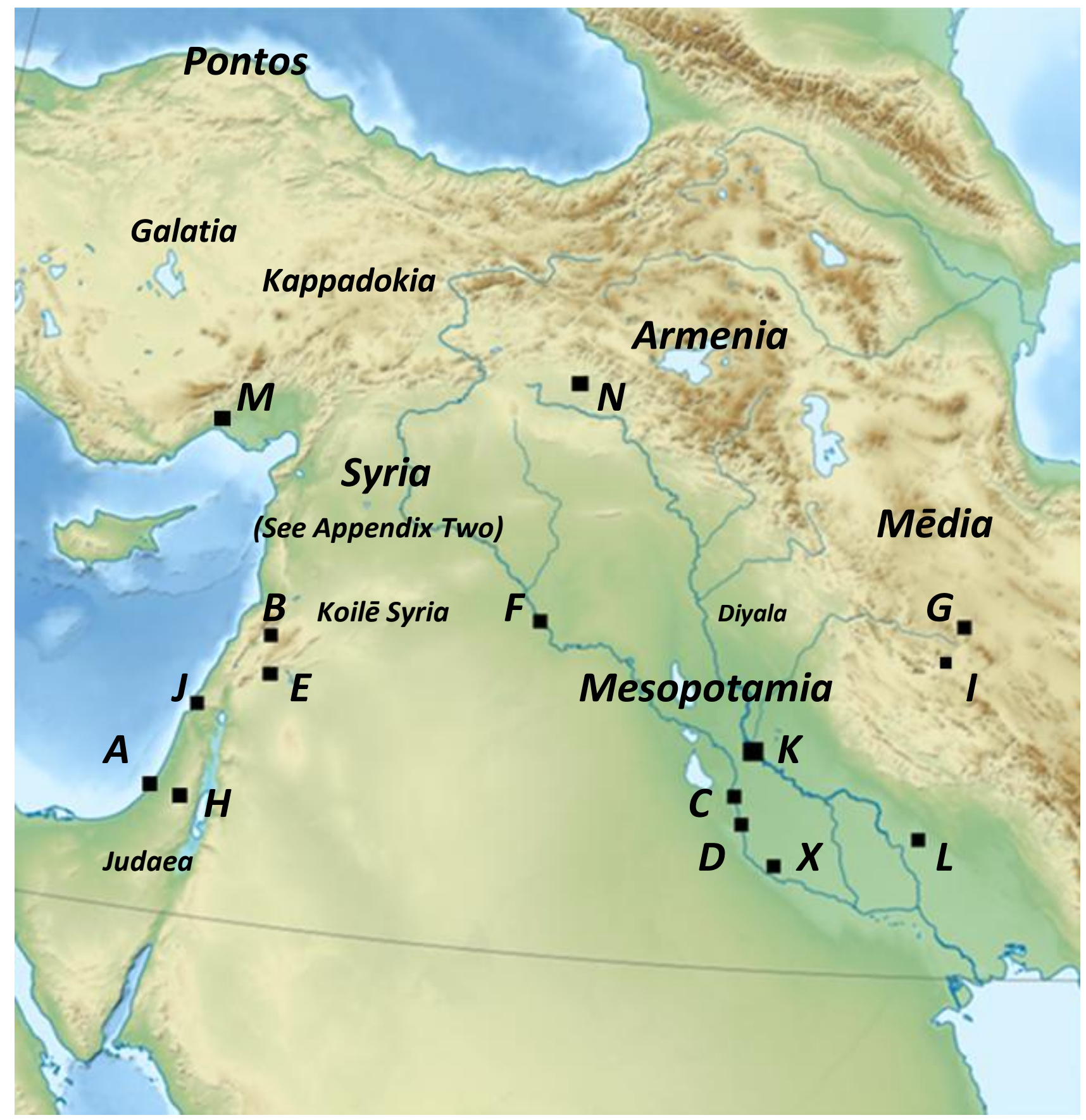

(Base map sourced from http://commons.wikimedia.org/wiki/File:Middle_East_topographic_map-blank.svg)
A: Askalōn
B: Baalbek
C: Babylon
D: Borsippa
E: Damascus

F: Doura-Eurōpos

G: Ekbatana

H: Jerusalem

I : Laodikeia-in-Mēdia

J : Ptolemais-Akē

K: Seleukeia-on-the-Tigris

L: Susa/Seleukeia-on-the-Eulaios

M:Tarsos

N: Tigranakerta

X: Uruk 
FIGURE FOUR: SELEUKID FAMILY TREE

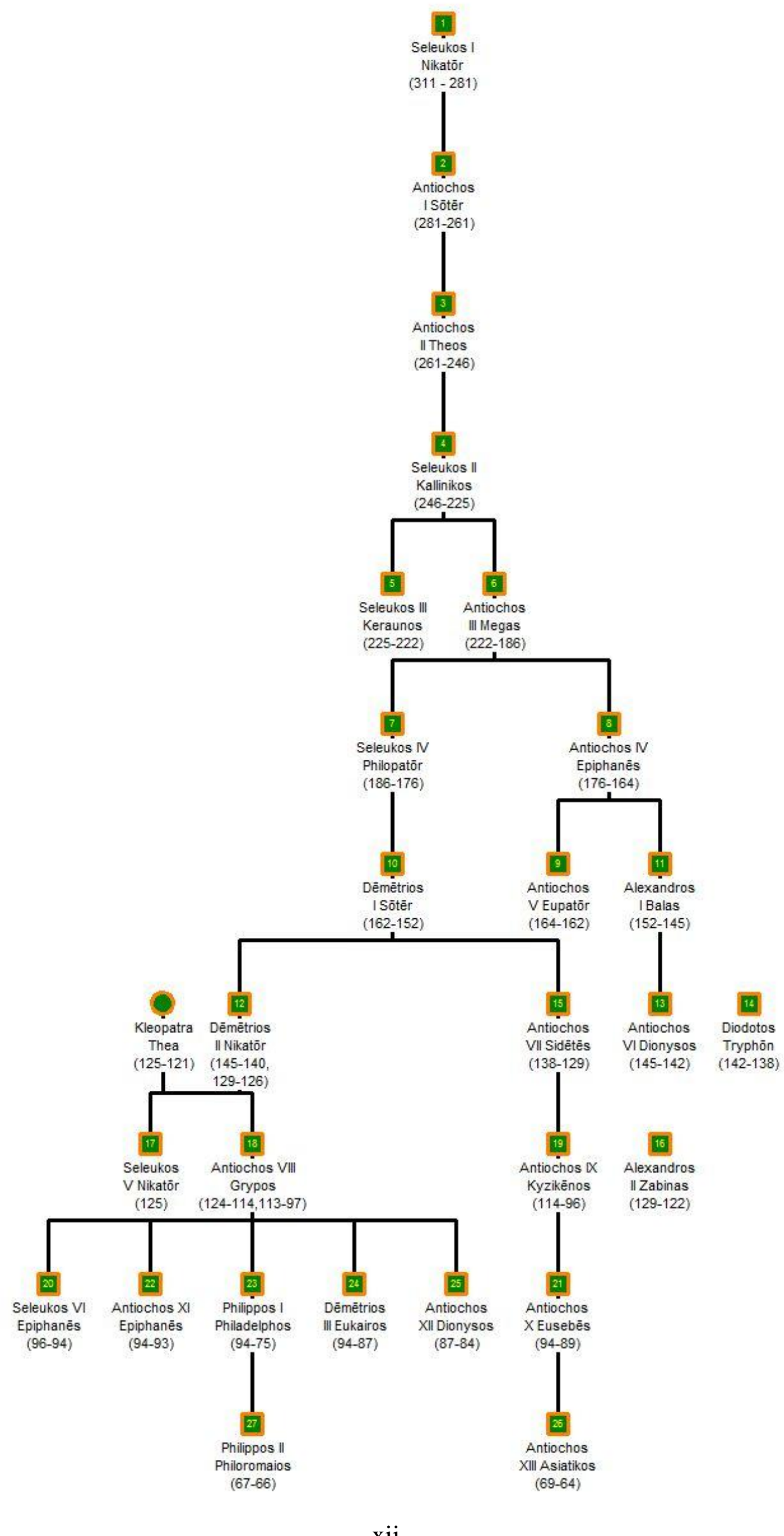




\section{INTRODUCTION}

In the Hellenistic period (323-30 BC) ${ }^{1}$ the Greeks spread across the east, taking their traditional political communities, the poleis ( $\pi$ ó $\lambda \varepsilon 1 \varsigma)$, with them. Poleis were traditionally self-sufficient and independent entities, but most existing poleis and all new poleis now came under the rule of the absolute monarchs ( $\beta \alpha \sigma \imath \lambda \varepsilon \tilde{i} \varsigma)$ of three vast kingdoms: the Seleukids in the east, the Ptolemies in Egypt, and the Antigonids in Macedon.

The relationship between the kings and poleis in Seleukid Asia Minor has long been the focus of scholarship on the Hellenistic polis (and a major focus of Hellenistic scholarship in general). This relationship was a complex one in which the poleis enjoyed a great deal of independence from the kings. This thesis argues that the relationship between the Seleukid kings and the poleis in the Seleukid heartland of Syria and Mesopotamia was very different. These poleis were institutionally and ideologically bound to the Seleukid dynasty to a degree that the poleis of Asia Minor were not.

The first chapter of this thesis is concerned with explaining the relationship between kings and poleis in Asia Minor. To that end, I first detail the ideological concerns of each party. The kings were primarily and personally concerned with warfare, had divine or semi-divine status, and modified their self-presentation in order to better suit individual groups of their subjects. The poleis highly valued their autonomia and eleutheria, flexible concepts which could imply total independence or be used to justify extensive interference within a polis. These ideological concerns shaped the unique relationship between the kings and the poleis of Asia Minor, alongside the practical difficulties the Seleukids had in maintaining control over the region. I use an inscription from Erythrai, OGIS 223, as an example of how this relationship was presented by the kings and the poleis. The king worked to depict himself as an ally, friend, and benefactor of the poleis, and the poleis worked to maintain as much independence as possible. When the poleis gave the king honours and resources, they represented them as motivated by gratitude for royal benefactions - not because they considered themselves the king's vassals. To maintain this relationship, the kings avoided interfering in the internal affairs of the poleis as a matter of course and they also offered frequent gifts to the poleis so that

\footnotetext{
${ }^{1}$ Unless otherwise noted, all dates in this thesis are BC. All names are transliterated from Greek according to the system used in Brill's New Pauly (minus the indication of stress accents), unless such would be truly intrusive, e.g. Alexander, Philip II, Antioch, Damascus - in these cases use of the traditional anglicisations also serves to differentiate them from homonymous individuals and cities.
} 
they remained in the royal debt. One particularly counterintuitive outcome of this relationship was that the kings often granted freedoms to poleis in Western Asia Minor in order to keep them in debt and therefore under control. These freedoms were not just a pretence - the poleis maintained control over their internal affairs and there is even evidence of them continuing to operate independently in foreign affairs and military matters. Thus the poleis in Asia Minor enjoyed a very large degree of freedom from the Seleukid monarch.

Chapter two moves the discussion to the Seleukid heartland of Syria and Mesopotamia, where Seleukos I founded (and his successors maintained) a system of cities, whose scale far exceeded the efforts of any of the other successor kingdoms. These cities formed two nodes: the Tetrapolis in Syria and Seleukeia-on-the-Tigris in Mesopotamia. These cities were poleis in the political sense; like the poleis in Asia Minor they possessed their own territories, their own sense of identity, and organs of selfgovernment. However, whereas the poleis in Asia Minor were difficult for the kings to control and were ultimately not essential to the kingdom, the poleis in Syria and Mesopotamia had a central role in the kingdom from their foundation. Several elements of the poleis were designed to tie them to the Seleukid dynasty: they contained large royal garrisons, were closely modelled on Macedon in order to discourage defections, and were given names, myths, and symbols which associated them with the Seleukid dynasty so that expressions of polis identity would also be expressions of loyalty and indebtedness to the dynasty. These Seleukid dynastic symbols were a major part of the poleis' identities, as shown by their survival in Syria well into Late Antiquity and by Antiochos IV's attempts to expand the system by giving similar names, myths, and symbols to native communities. A clear example of the way civic and royal symbols worked together is offered by the semi-civic semi-royal bronze coinages issued under Antiochos IV.

Chapter three moves on to consider the relationship between Seleukid kings and the poleis of the Seleukid heartland, paying especial attention to the civic institutional structures with which the kings interacted. The kings interfered in the internal affairs of these poleis both personally and institutionally, but IGLS 4.1261, an inscription from Laodikeia-by-the-Sea, shows that the poleis dealt with at least some internal matters themselves. Another inscription, IGLS 3.2.1183 from Seleukeia-in-Pieria, records an official interaction between king and polis. The submission of Seleukeia-in-Pieria to the king is made very clear: the king's letter is direct and the polis explicitly acknowledges it 
as a command. Within the royal aegis, however, Seleukeia-in-Pieria also presents itself as an autonomous actor. The crux of the relationship between the Seleukid kings and the poleis of the Seleukid heartland was the office of epistates, which the kings seem to have viewed as a royal official and the poleis as a chief magistrate. The epistatai maintained a close alliance with the civic archons, and together they controlled the polis - their power over the polis was based on the harmony between royal and civic spheres. The Syrian and Mesopotamian poleis' relationship with the king was thus a central part of their internal political structure as well as their civic identities. In the final, tumultuous years of the Seleukid dynasty, the kings became increasingly reliant upon the Syrian poleis and the poleis became more assertive in their interactions with the kings, but they did not seek complete independence. In fact, once the dynasty ceased to exist, the poleis invited Tigranēs of Armenia in as a replacement rather than become independent.

Thus, while still poleis, the cities of the Seleukid heartland were different from those of Asia Minor - their relationship with the king was a central part of the identities and political structure in a way which was inconceivable to the poleis of Asia Minor.

The thesis is followed by two appendices. Full text and translations of all the inscriptions quoted in this thesis are included in appendix one (page 113). Details of all coins cited are included in appendix two (page 160). 


\section{CHAPTER ONE: KINGS AND CITIES IN THE HELLENISTIC PERIOD}

The relationship between kings and poleis in the Hellenistic Period was shaped by the conflicting ideological interests of both parties. The kings desired both taxes to fund their campaigns and acknowledgement of their supreme status, but they were flexible about how that acknowledgement was to be given. On the other hand, the poleis placed enormous value on the idea that they were self-governing and autonomous, but they also had precedents which allowed them to reconcile those ideas with being under foreign rule. Kings and poleis were thus able to develop a unique relationship in which the king addressed the poleis as if they were his autonomous allies, rather than his subjects, and he allowed them to manage their own affairs. The poleis were even allowed to carry on a semi-independent foreign policy, so long as they continued to acknowledge that these freedoms were a gift of the king, to whom they were thus deeply indebted. This relationship has been reconstructed largely on the basis of evidence from Asia Minor, and many of the factors which encouraged its development were specific to that region: Asia Minor was distant from the royal centre of power, was contested with the other Hellenistic kingdoms, and frequently drifted out of royal control altogether. As a result, the Seleukid king's relationship with the poleis of Asia Minor need not have been typical of his relationship with the poleis elsewhere in his realm.

\section{The Hellenistic King}

All three Hellenistic monarchies mostly conformed to a single model of kingship, which coloured the actions and attitudes of those interacting with the king and of the king himself. $^{2}$ As a result, this model was a central factor in the relationships between kings and poleis. Under this model, the king was an absolute monarch, primarily and personally concerned with warfare, who held divine or semi-divine status and presented himself in a number of different guises depending on his audience. In many ways these characteristics were a natural development of the Macedonian kingship exercised by Philip II and Alexander, ${ }^{3}$ but they also reflect the process of experimentation which occurred during the diadochoi's struggle for power and survival after Alexander's death. ${ }^{4}$ The duties and rights which the kings held according to this model of kingship significantly affected the ways in which they interacted with their subjects, rivals, and poleis.

\footnotetext{
${ }^{2}$ Davies (2002) 1-4.

${ }^{3}$ Bell (2004) 116; Hammond (1993b) 12ff.; Pollitt (1986) $19 \mathrm{ff}$.

${ }^{4}$ Ehrenberg (1969) 159.
} 


\section{Military Prowess}

Alexander was the paradigm which the diadochoi and the later Hellenistic kings aspired to emulate. ${ }^{5}$ By dint of his ancestry and in particular his personal achievements, he had clearly out-ranked all other Macedonians and had therefore been able to exercise essentially absolute authority over them. After his death nobody was similarly dominant, so the top-ranking Macedonians were largely unwilling to obey anyone and began to act independently. ${ }^{6}$ This independent spirit passed down the ranks - why should the district governors and lieutenants obey the satraps and generals who had themselves refused to obey (and eventually slaughtered) Perdikkas, the Regent in Babylon? In order to assert their authority over their Macedonian subordinates (and those Macedonians whom they wished to make their subordinates) it was natural and necessary for the diadochoi to present themselves as dominant figures in the same mould as Alexander. ${ }^{7}$ To do that, it was necessary for them to stress their personal military prowess, even more than it had been for Alexander because they had no royal ancestry to emphasise. ${ }^{8}$ As one of the Suda entries on $\beta \alpha \sigma \imath \lambda \varepsilon v ́ \varsigma$, which has a Hellenistic source, ${ }^{9}$ puts it:

Neither individual character, nor justice gives kingdoms to men, but [they are given] to those who can lead an army and manage affairs sensibly: such were Philip and the successors of Alexander.

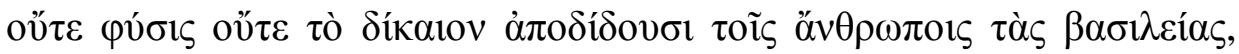

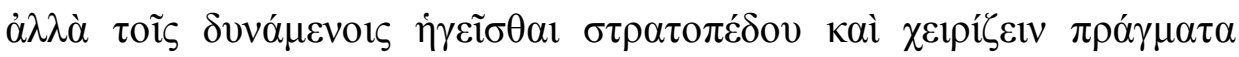

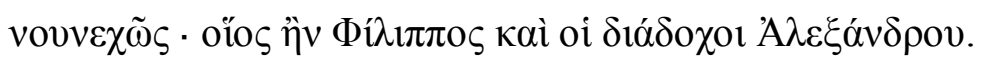

(Suda B147)

The test presented in this passage is a very practical one - those who received and kept kingdoms were those who managed to get their states operational and fight off the other diadochoi. Those diadochoi who failed to accomplish this were eliminated, regardless of how virtuous or noble they were. Hellenistic monarchy thus gained a distinctly military character, ${ }^{10}$ which never disappeared; every time a new Ptolemy or Seleukid came to the

\footnotetext{
${ }^{5}$ Ehrenberg (1969) 141.

${ }^{6}$ Dunn (2012) 9; Grainger (2010) 15; Heckel (2002) 81-96.

${ }^{7}$ Dunn (2012) 45; Sherwin-White \& Kuhrt (1993) 120.

${ }^{8}$ Kratēros and Dēmētrios Poliorketēs also emphasised their heroic youth as Alexander had - they were the only diadochoi young enough for this to be a realistic option.

${ }^{9}$ Billows (1990) 21; Sherwin-White \& Kuhrt (1993) 120 \& 129.

${ }^{10}$ Chaniotis (2005) 57; Ma (1999) 108.
} 
throne, they would launch a new war over Syria, largely in order to establish their right to rule within their own kingdom. ${ }^{11}$ Hellenistic kings regularly justified their authority over

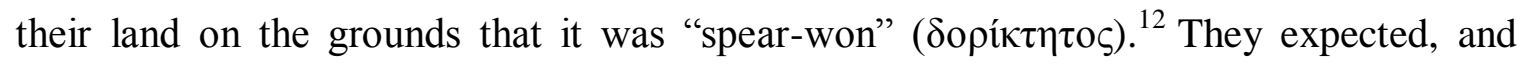
were expected to, lead from the front - their personal military ventures and credentials were emphasised in statues, ${ }^{13}$ paintings, ${ }^{14}$ inscriptions, ${ }^{15}$ and propaganda accounts. ${ }^{16}$ All other duties of the king were subordinate to his role as a military commander. ${ }^{17}$ For example, Antiochos III spent four or five years campaigning in the east, ${ }^{18}$ during which time his contact with the core of his kingdom would have been intermittent. ${ }^{19}$ Similarly, the Babylonian Astronomical Diaries imply that Antiochos IV was only intermittently in contact with Seleukeia-on-the-Tigris and Babylon during his campaign to Armenia, Iran, and the Persian Gulf in $165 .^{20}$ Thus, this focus on military expeditions had implications for the degree of control which the kings could exercise over the operation of their realm. ${ }^{21}$ The military campaigns must also have been enormously expensive in money, food, and men - and therefore had implications for what the kings demanded of their subjects.

\section{Royal Divinity}

The second important element of Hellenistic kingship was its divine element. Hellenistic kings were regularly portrayed as gods and given cult worship as gods. Links between royalty and the divine were rapidly adopted by Alexander's successors. ${ }^{22}$ When Dēmētrios Poliorkētēs entered Athens in 307, he was greeted by the Athenians as a god, complete with his own hymn. ${ }^{23}$ The kings also took epithets which implied divinity; the epithet "saviour" ( $\sigma \omega \tau \eta \dot{\rho})$, for example, was adopted by Ptolemaios I and Antiochos I,

\footnotetext{
${ }^{11}$ Grainger (2010) 89.

12 e.g. Polyb.18.51.4. Aalders (1975) 17.

${ }^{13}$ Smith (1988) 33; Pollitt (1986) 31ff.

${ }^{14}$ Pollitt (1986) $41 \mathrm{ff}$.

15 e.g. The Adulis Inscription (OGIS 54). Ptolemaios III recounts and aggrandises his personal role in events.

${ }^{17}$ Billows (1995) 20. have returned before 205. Ma makes it six years: (2003) 178. continued operation of his bureaucracy.

${ }^{20}$ Gera \& Horowitz (1997) 241, 244-5, analysing AD -164 Obv. B15, C13ff.

${ }^{21}$ Dmitriev (2005) 301.

${ }^{22}$ Dunn (2012) 53.

${ }^{23}$ Ath. 253C-F; Diod. Sic. 20.46 \& Plut. Demetr. 10-13.
}

${ }^{16}$ e.g. The Garoub Papyrus BNJ 160 F 1, a letter from the front during the Third Syrian War, in which

${ }^{18} \mathrm{He}$ is already in Mēdia fighting against Arsakēs at Polyb.10.27, simultaneous with the death of Claudius Marcellus in 208, and the siege of Bactra is at Polyb.11.34, after Hasdrubal Gisco was driven out of Spain in 206. After the conclusion of that siege he proceeded to India and then wintered in Karmania - he cannot

${ }^{19}$ Contrast, for example, Justinian who had to send Belisarios and Narsēs to fight his wars in Peria, Africa, and Italy because his presence at Constantinople to answer appeals and issue rescripts was essential to the 
which had previously been attached to figures like Dēmētēr, ${ }^{24}$ Apollo, ${ }^{25}$ and, especially, Zeus. ${ }^{26}$ Antiochos II's epithet left no room for doubt - he was literally called "god" $\left(\Theta \varepsilon \delta \delta_{\zeta}\right){ }^{27}$ The kings were not passive recipients of these divine honours; they actively propagated them. For instance, the story that Seleukos' father was Apollo (mimicking Alexander's descent from Zeus) was first revealed by Seleukos himself, and was actively referenced on his coins, a medium over which he had total control. ${ }^{28}$ At least initially, being depicted on coins at all implied divine status for, before Alexander, only civic deities, the Great King (who, so far as the Greeks were concerned, presented himself as divine), ${ }^{29}$ and the occasional (over)-ambitious satrap had been depicted on coinage. ${ }^{30}$ The divine implications are unmistakeable when the kings are depicted in the guise of a deity - with Heliote rays or horns projecting from their heads, for example. ${ }^{31}$ Moreover, like the gods, they engaged in boundary-crossing, as in Antiochos I's marriage to his stepmother Stratonike, Ptolemaic sibling-marriage, and the kings' lavish and conspicuous luxury - acts which marked them as superior beings, wielding great power and free from normal codes of conduct. ${ }^{32}$

Royal divinisation probably results from the same initial factors which lie behind royal militarism. In practice, the various Macedonians in positions of authority after Alexander's death had no more right to royal power than anybody else. ${ }^{33}$ Thus, each had to assert that they were the best candidate for rule on account of their personal superiority over their rivals. This was the portion of the Hellenistic kingship model which the philosophers concentrated their discussions on, following Aristotle's declaration about the only circumstance in which monarchy would be just:

Should it happen that either a whole family or even a single individual in a society bears himself with so much excellence that it exceeds that of

\footnotetext{
${ }^{24}$ e.g. Hymn. Hom. Dem. 22.5.

25 e.g. Soph. OT 150.

${ }^{26}$ e.g. Menander exclusively uses the word as an epithet of Zeus: Dys. 690; Epit. 907; F532.2; F536.7; F581.2; F656.7.

${ }^{27}$ App. Syr. 11.65 .

${ }^{28}$ Just. Epit. 15.4.3; Dunn (2012) 50; Grainger (1990b) 3; Howgego (1995) 66.

${ }^{29}$ Howgego (1995) 65.

${ }^{30}$ Erickson \& Wright (2011) 164.

${ }^{31}$ Dunn interprets the depiction of Alexander (for the first time) on coins of the Diadochoi as part of their apotheosis of him: (2012) 58; Pollitt (1986) 32ff.

${ }^{32}$ Ager (2006) 166, 176-178.

${ }^{33}$ Dunn (2012) 9; Grainger (2010) 15; Heckel (2002) 81-96.
} 
everyone else, then it is just for that family to be royal and in charge of everything or for that single individual to be king.

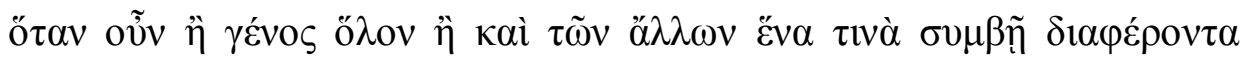

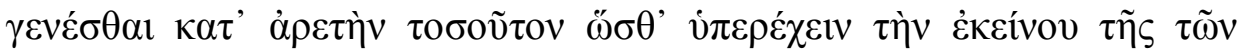

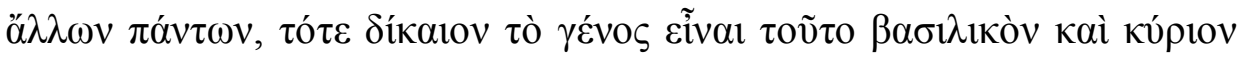

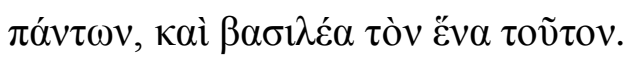

(Arist. Pol.1288a 15-19)

Alexander and the Hellenistic kings after him regularly presented themselves as men of this sort, who utterly exceeded everyone else in every way. ${ }^{34}$ Such constant assertion of superiority had been a major element of Alexander's kingship and exceeding Alexander in any matter, no matter how minor, was therefore very dangerous, as the page Hermolaos discovered when he killed Alexander's quarry in $327 .{ }^{35}$ Just like the emphasis on military prowess, this aspect of kingship flowed on and was amplified by the diadochoi - stories and images were produced which emphasised that the diadochoi were the strongest, ${ }^{36}$ the richest, ${ }^{37}$ the most generous, ${ }^{38}$ and the most merciful. ${ }^{39}$ They were presented as delivering justice with such perfection that they were "law in living form"

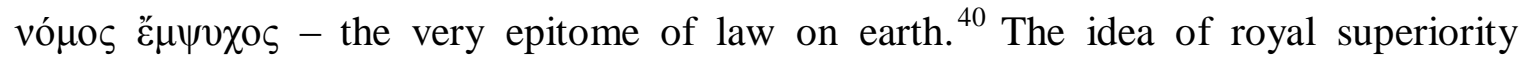
stressed the kings' competence was a source of legitimacy, just as the emphasis placed on military prowess did. However, this approach also attempted to make the case for moral legitimacy - that it was just for the kings to rule.

The kings' superiority was so marked compared to other people that it was as if they were gods. ${ }^{41}$ In fact, the gods who ruled over the universe presented a useful analogy for the new absolute kingship, especially as the Greeks had no earthly metaphor for power both absolute and legitimate. ${ }^{42}$ When people wielded absolute power in a polis, they were tyrants, unfairly dominating people who ought to be their equals; by definition

\footnotetext{
${ }^{34}$ Downey (1941) 165; Smith (1988) 38ff.

${ }^{35}$ Arr. Anab. 4.13.2. On the importance of hunting in particular for establishing royal excellence: Carney (2002) esp.68; Pollitt (1986) 38ff.; \& Plut. Alex. 40.4.

36 e.g. The story of Seleukos single-handedly wrestling a bull to the ground: App. Syr. 9.57.

${ }^{37}$ e.g. The opulent dinner at Daphnē of Antiochos VIII: Ath. 12.540a-b.

38 e.g. ibid., and also "[Ptolemaios I] said that enriching is more regal than being rich," $\tau$ oṽ $\pi \lambda$ ov $\tau \varepsilon \tilde{v} v$ है $\lambda \varepsilon \gamma \varepsilon$

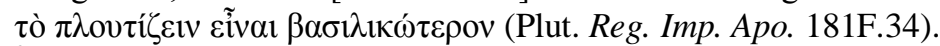

${ }^{39}$ e.g. Seleukos surrendering his wife to his lovestruck son: Lucian, Syr.D.18.

${ }^{40}$ Aalders (1975) 26; e.g. Ps.Archytas Frag.33; Ps.Philo De Vita Mosis 2.4

${ }^{41}$ Chaniotis (2003) 433.

${ }^{42}$ Aalders (1975) 31.
} 
their power was illegitimate. ${ }^{43}$ The absolute kingship which the Greeks perceived as the Achaimenid model was off-limits for similar reasons. ${ }^{44}$ Macedonian kingship had historically been one in which the king's power was open to at least some challenge by the nobility. ${ }^{45}$ Even the Homeric heroes failed to furnish a perfect model - the central tension of the Iliad is the result of Agamemnōn's illegitimate (and ineffectual) attempt to control Achilleus. On the other hand, a precedent for presenting a legitimate sovereign as divine already existed in the fifth and fourth century Athenian depictions of their demos as a divine king on the model of Zeus. ${ }^{46}$ Only one who was utterly superior, like Zeus or the lord of a household, ${ }^{47}$ could legitimately exercise absolute power over others. ${ }^{48}$

That this analogy was the central aspect of the kings' claims to divinity can be seen from the fact that the kings' divinity seems to have been mostly ideological and honorific. The kings' divine honours were often described as "equal to the gods," implicitly maintaining a distinction between the king and the gods. ${ }^{49}$ No polis would refer to, say, Apollo as receiving "honours equal to the gods." In life, the kings did not wear the horns and other accoutrements of divinity that they were depicted with in art, both of which suggest that they only took their claims to divine status so far. ${ }^{50}$ It was the metaphor that was essential, for while legitimate absolute monarchs were new, the gods were not - the metaphor gave the kings a precedent for the legitimate exercise of absolute power (one which also flattered their egos). As will be discussed on page 20 it also gave the kings' subjects a model for interactions with him, one which the poleis adopted eagerly.

\section{Combination of Roles}

The aforementioned military and divine elements were significant aspects of Hellenistic kingship. The third major aspect of the Hellenistic king was that he legitimated his power towards different audiences by tailoring his self-presentation to each audience's particular expectations of their ruler. ${ }^{51}$ Philip II foreshadowed this element in his combination of the

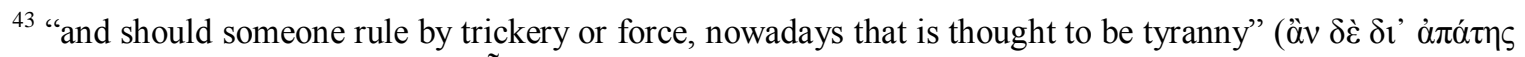

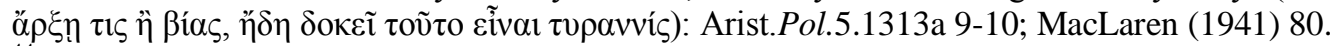

${ }^{44}$ Davies (2002) 4.

${ }^{45}$ Hatzopoulos (1996) 267.

${ }^{46}$ Ehrenberg (1969) 98; Glowacki (2003) 450ff.

${ }^{47}$ Arist. Pol. 1285b 31-33 (Frequently also paralleled with the gods).

48 Anagnostou-Laourtides (2012) 6; Bevan (1901) 632.

${ }^{49}$ Chaniotis (2003) 433. For a similar argument regarding Babylonian records: Linssen (2004) 128.

${ }^{50}$ Grant (1982) 98; Smith (1988) 38-39.

${ }^{51}$ Anagnostou-Laoutides (2012) 2; Bosworth (2002) 4; Ma (1999) 7.
} 
roles of hegemōn of the Corinthian League, Thessalian tagos, and Macedonian king, all of which remained quite separate offices. ${ }^{52}$ The Achaimenid kings were probably a major model, also. ${ }^{53}$ Each of the kings ruled over different sets of audiences and therefore each king combined different sets of roles. For example, the Seleukid king was simultaneously a Macedonian-style basileus and a Babylonian king (舀 LÚ.GAL / šarru), ${ }^{54}$ fulfilling the customary roles of that office. For example, Antiochos I personally moulded bricks and performed a traditional Babylonian foundation ceremony for the reconstruction of Nabû's Ezida temple at Borsippa. ${ }^{55}$ The Ptolemaic king ruled his Macedonian subjects as a basileus, like the Seleukid kings, but was a Pharaoh ( $\underset{\text { s }}{\mathrm{s}} n$ nswt-bjty) to his Egyptian subjects, and hegemōn to the Greeks of the Aegean Islands. ${ }^{56}$ In each role, the source and theoretical nature of the king's authority was different - as Pharaoh he was the son of Amen-Re and incarnation of Horus, personally sustaining the universe, ${ }^{57}$ while as hegemōn he managed a league according to treaty. ${ }^{58}$ The degree to which the king was able to keep all these roles separate is unclear; ${ }^{59}$ there was at least some permeance, especially as time went on. ${ }^{60}$ The different combinations of roles in each kingdom may thus account for the differences which developed between the three monarchies; the less absolute rule of the Antigonids reflecting the importance of hegemonies among their combination of roles, while the strongly institutional nature of Pharaonic kingship might be responsible for the degree to which the Ptolemaic kingdom centred on the institution of the king, rather than his person. The kings encouraged different audiences to view them according to their particular preferences, but they may not have had much choice; native Egyptians, who remained an important part of the Ptolemaic administration, ${ }^{61}$ would not easily accept - or even understand - a king who was not a Pharaoh. ${ }^{62}$

\footnotetext{
${ }^{52}$ Perlman (1985) 155. It is, in this respect, different from the 'policy of fusion' attributed to the late reign of Alexander, in which roles were merged.

${ }^{53}$ Briant (1990) 41, 53.

54 e.g. AD -260 Upper Edge 1; Boiy (2011) 3-4.

${ }^{55}$ Borsippa Cylinder 1.5-1.14, in Kuhrt \& Sherwin-White (1991) 74-77.

${ }^{56}$ Bagnall (1976) 156.

${ }^{57}$ Koenen (1993) 114; Lloyd (1982) 48.

${ }^{58}$ Bagnall (1976) 136ff.; Merker (1970) 157.

${ }^{59}$ Sherwin-White \& Kuhrt (1993) 144.

${ }^{60}$ e.g. Even depictions of the Ptolemies in traditional Pharaonic guise show some Greek influence from the reign of Ptolemy I: Bothmer (1952) 56; the Ptolemaic ruler cult, intended for a Greek audience, may be based on (a Greek interpretation of) the Egyptian Pharaonic cults: Dunn (2012) 61 n.321; Hellenistic royal palaces incorporate both Greek and Near Eastern elements: Kutbay (1998) 82, 140; .Nielsen (1996) 209212.

${ }^{61}$ Lloyd (2002) 180.

${ }^{62}$ Dundas (2002) 439, 442.
} 
Royal iconography sometimes emphasised a specific role - the depictions of Ptolemaios XII on the pylons of the Temple of Horus at Edfu, for example, put him in the traditional Egyptian role of the Pharaoh personally slaying the barbarians ${ }^{63}$ and are almost indistinguishable from Karnak and Abu Simbel's depictions of Ramesses II fighting at Qadesh, made a thousand years before. ${ }^{64}$ At other times royal iconography was constructed to appeal to multiple audiences simultaneously - common on silver and gold coinage, which could pass from one audience to another in the course of commerce. The widespread Seleukid coin-type depicting Apollo sitting on an omphalos is an example for Greco-Macedonian audiences the design recalled the Seleukid dynasty's relationship with Apollo (the aristocratic Greek god par excellence), for his Iranian subjects the image could also recall the Achaimenid royal archer, ${ }^{65}$ and for his Mesopotamian subjects the patronage of Šamaš (god of justice and the Sun). ${ }^{66}$ The result of this facet of Hellenistic kingship was that everybody understood that the king was in charge, but they understood him to be in charge for different reasons in different places. It was, therefore, completely open to the poleis to interpret the king in a role which fitted their needs - as long as they acknowledged his authority, he did not mind how they justified that acknowledgement.

Thus the Hellenistic royal ideology enabled and legitimised the absolute power of the kings. It also placed demands on them. Justification by military prowess, for example, required that the king spend a great deal of time on campaign. This meant that he needed as much money, resources and men as he could get from his subjects, including the poleis, while also limiting his ability to micromanage their affairs. He presented himself as superior in every way, encouraging his Greco-Macedonian subjects to make analogies between him and the divine, but allowed individual groups of subjects to negotiate how they would acknowledge his superiority according to their specific ideological needs and interests. Therefore, the particular ideological needs of the poleis are of central importance to understanding their relationship with the kings.

\footnotetext{
${ }^{63}$ Delia (1993) 203; Siani-Davies (1997) 333. Cf. also the careful identification of Berenikē II with the goddess Hathor in art and epigraphy intended for an Egyptian audience, Llewellyn-Jones \& Winder (2011) $257 \mathrm{ff}$.

${ }^{64}$ Personal Observation (2011).

${ }^{65}$ Erickson \& Wright (2011) 163 \& Iossif (2011) 257. contra. Zahle (1990) 133.

${ }^{66}$ Anagnostou-Laoutides (2012) 3, who proposes, also, that Zeus imagery would have recalled the Bēl Marduk.
} 


\section{The Hellenistic Polis}

The polis ( $\pi$ ó $\lambda 1 \zeta)$ was a cornerstone of Classical Greek civilisation, and, like all fundamental ancient concepts, it has proven exceptionally difficult to define. ${ }^{67}$ As pointed out by Mogens Herman Hansen and the Copenhagen Polis Centre, modern scholars speaking of the polis have a much more specific concept in mind than what the Greeks meant by $\pi$ ó $\lambda$ is. For the Greeks, the term had multiple topographical, urban and political meanings. As a result, they often used the term vaguely; they were perfectly comfortable referring to the Near Eastern cities, such as Babylon, as poleis, even though such cities were definitely not poleis in the political sense. ${ }^{68}$ For the political sense of the word, Pausanias 10.4.1 provides the best example of a Greek attempting to define the term - confronted with the polis of Panopeus in Phōkis, which was no more than a collection of shacks by a mountain stream, Pausanias was unsure whether it could rightly be called a polis. Pausanias noted that Panopeus lacked a town hall, gymnasion, theatre, agora, even a well. But he concluded:

Nevertheless, there are boundaries to their territory with their neighbours and they even send delegates to the Phōkian Assembly. And they say that the name of their polis comes from the father of Epeios, and that they are not Phōkeians, but Phlegyans in origin...

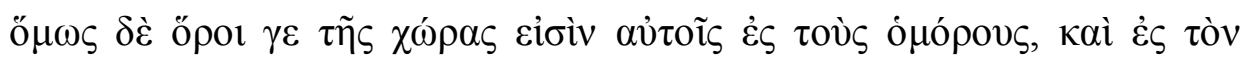

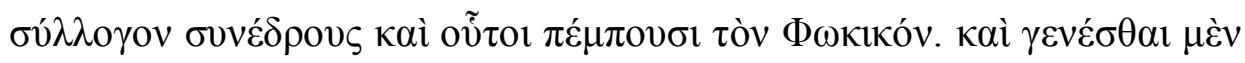

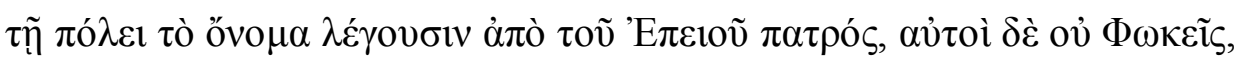

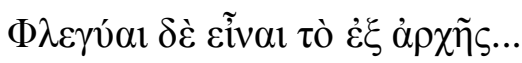

(Paus. 10.4.1)

These three factors: a defined territory, political agency manifested as self-government, and a communal mythic history, ultimately convinced Pausanias that this collection of hovels was indeed a polis politically, even if it seemed inadequately urbanised. ${ }^{69}$ When modern scholarship speaks of the polis, it is almost invariably this distinctively Greek

\footnotetext{
${ }^{67}$ Hansen, Polis (2006) is the definitive work, summing up twenty years of active investigation of this issue by the driving force behind the Copenhagen Polis Centre.

${ }^{68}$ Hansen (2000) 180-181.

${ }^{69}$ The passage is sometimes taken to be listing the buildings necessary for a settlement to be a polis: e.g Steele (1992) 59. I do not find that reading persuasive because Pausanias decides that, despite lacking those buildings, Panopeus is indeed a polis.
} 
socio-political institution which is meant - the city-state. ${ }^{70}$ In political terms, then, the polis had a territory, a sense of community, and self-government. ${ }^{71}$ The polis as a sociopolitical institution was not a static entity, but a dynamic one, which developed from the unique circumstances of the Greek Archaic Period. Initially dominated by aristocrats, the portion of the populace which was involved in government progressively widened throughout the Classical Period. In the Hellenistic period poleis continued to evolve, widening the franchise further in some ways, and narrowing it in others: for example, the public roles available to women and foreigners increased dramatically, ${ }^{72}$ but offices, duties, and major decision-making power were increasingly concentrated in the hands of the very richest citizens. ${ }^{73}$

The advent of the Hellenistic king caused a more fundamental change - poleis ceased to be the dominant political forces in the Greek world. But the polis did not become extinct: it remained "the normative political institution in international affairs,"74 and political philosophy continued to assume that the polis was the default, in part because it was dangerous to question the nature and limits of royal power, but largely because the polis continued to be what most Greeks experienced on a day-to-day basis. ${ }^{75}$ The poleis' continued vitality under the Hellenistic kings is not so surprising; the Anatolian poleis had survived, even prospered, under the rule of the Persian Empire and under the hegemonic leagues of the fifth and fourth centuries. ${ }^{76}$ However, the exact fate of a given polis in this new age of royal dominance could differ substantially. In many places, poleis were either strong enough or distant enough from centres of power that they remained free actors - Rhodes, ${ }^{77}$ Syracuse, ${ }^{78}$ and (to a lesser extent) Sparta fall into the former category, ${ }^{79}$ Hērakleia Pontikē, ${ }^{80}$ and Massalia into the latter. ${ }^{81}$ Other poleis

\footnotetext{
${ }^{70}$ Murray (2000) 233-235. Modern scholarly terms generally have more precise meanings than the equivalent terms in the classical languages - Nevett notes that the various terms for Greek pottery types were used far more flexibly by the Greeks than they are by modern scholars: (1999) 41.

${ }^{71}$ Hansen (2006) 56-65 is the definitive treatment of the issue.

${ }^{72}$ Hansen (2006) 132; van Bremen (1996) 1, 25 \& 34

${ }^{73}$ Jones (1940) 164ff.; Lambert (2012) 78 \& 83 provides an example in which both the trend towards widening and towards narrowing manifested simultaneously.

${ }^{74}$ Green (2007) xx.

${ }^{75}$ Hammond (1951) 30 \& 40f.; Manicas (1982) 678. Plut. Prae. Ger. Reip. \& An Seni show that polis politics remained philosophically important under Roman rule (and practically important - both are couched as advice for contemporaries engaging in polis politics). His fragmentary De Monarchia continues the standard Greek debate about monarchy, oligarchy, and democracy - apparently the discussion is still set in the polis.

${ }^{76}$ Starr (1975) 84-87.

${ }^{77}$ Berthold (1984) 44, 47 \& 199.

${ }^{78}$ Meister (1984) 384-411.

${ }^{79}$ Cartledge \& Spawforth (2002) 26-28.
} 
were subject to strong royal influence but still retained the ability to operate as independent actors some of the time - Athens ${ }^{82}$ and most of the Peloponnese fell in this category. ${ }^{83}$ Yet another group were subsumed within the new kingdoms; poleis in this category included Thessaly, ${ }^{84}$ Cyrene,${ }^{85}$ and, most significantly, the poleis of Western Asia Minor.

\section{Western Asia Minor}

It is these poleis in Western Asia Minor, subordinate to the Seleukid monarchs, on which scholarly discussion of the Hellenistic polis has focused. This focus has arisen in large part because there is a great deal of data for poleis in Asia Minor, in a period infamous for lack of data. The region is comparatively well-excavated ${ }^{86}$ and inscriptions are very common, allowing scholars to study the internal operations of the poleis and their interactions with the kings directly, rather than through references in the literary sources. As a result, the relationship between the king and the cities of Asia Minor is the most intensively studied element of all the aspects of the Seleukid kingdom - probably out of all proportion to its relevance to the actual operation of the kingdom as a whole (see Figure one for a map of Western Asia Minor). ${ }^{87}$

Further, the literary sources are sufficiently interested in Asia Minor that it is possible to construct a coherent narrative of the region's history - something which cannot be done in Syria, for example. The poleis of the region had been under foreign rule since the Archaic period - first of the Lydians and then of the Persians. Persian rule was frequently interrupted due to the great distances involved and the rebelliousness of the satraps. ${ }^{88}$ Even when the Persians were fully in control, they allowed the poleis significant self-government and patronised their temples. ${ }^{89}$ Nevertheless, the liberation of the poleis of Asia Minor came to be incredibly important in Greek political thought,

\footnotetext{
${ }^{80}$ Burstein (1976) 90.

${ }^{81}$ Morel (2006) 411.

${ }^{82}$ Ferguson, Hellenistic Athens (1911) is the foundational text.

${ }^{83}$ Larsen (1968) 215-312.

${ }^{84}$ Martin (1985) 132-165.

${ }^{85}$ Will (1982) 1.36-38.

${ }^{86}$ Ephesos, for example, was first excavated in 1863, and now lies almost entirely uncovered: Ephesus Foundation, "Excavation History," http://www.ephesus-foundation.org/about-ephesus-excavationhistory.aspx (accessed $7^{\text {th }}$ November 2012); Personal Observation 2010.

${ }^{87}$ Davies (2002) 4.

${ }^{88}$ Bevan (1902) $1.78 \& 1.87$; Starr (1975) 70.

${ }^{89}$ Lund (1992) 111; Starr (1975) 42.
} 
partially justifying the Athenian naval empire, Spartan expansion under Agēsilaos II, and the campaign of Alexander. ${ }^{90}$ Each of these attempts to liberate the poleis of Asia Minor from Persian rule saw them brought briefly under the control of Greek overlords who were at least as onerous as the Persians - often, once the lustre of liberation wore off, the Greek overlords looked unfavourable in comparison. ${ }^{91}$ Thus their experience under Persian rule conditioned the poleis' expectations of the sort of overlord which the new Hellenistic kings would be: distant, loosely in control, and willing to allow substantial or complete freedom.

After Alexander's death, Asia Minor was the base for Antigonos I Monophthalamos, and thus at the very heart of the conflict between the diadochoi ${ }^{92}$ It passed to Lysimachos after Ipsos $(301)^{93}$ and to Seleukos after Koroupedion (281), but Seleukos was assassinated a few months later. ${ }^{94}$ Seleukos therefore never had any opportunity to incorporate the territory into the Seleukid state in the way he had in Syria and Mesopotamia. ${ }^{95}$ Any organisation that might have been inherited from Antigonid rule was seriously damaged by the invasion of the Gauls (280) and by the reassertion of strong regional tendencies. Local potentates presided over defences against the Gauls, who continued to raid the lowlands from their stronghold in what came to be known as Galatia, which sat between Western Asia Minor and the Seleukid heartland, further complicating Seleukid attempts to control the territory. The local potentates quickly developed independent or autonomous kingdoms, such as Kappadokia, Pontos, Bithynia, and Pergamōn. Many poleis, notably Smyrna and Hērakleia Pontikē, acted similarly. Antiochos I retook parts of the region in the late $270 \mathrm{~s},{ }^{96}$ but his control remained highly contested and he never had the opportunity to properly settle matters in the region.

The remaining territories in Asia Minor centred on Sardis and Ephesos and were connected to the rest of the Seleukid Empire by the ancient royal road. Flanked on either side by potentially hostile tribes and kingdoms, this tenuous connection was easily severed. It was natural, therefore, that the territories tended to be entrusted to a single

\footnotetext{
${ }^{90}$ Bevan (1902) 1.87.

${ }^{91}$ Lund (1992) 111; Starr (1975) 84.

${ }^{92}$ Billows (1990); Will (1984a) 27 \& 39-61.

${ }^{93}$ Diod. Sic. 20.108-21.4; Plut. Demetr. 28-30; Will (1984a) 60.

${ }^{94}$ App. Syr. 10.62; Nep.21.3; Will (1984b) 113.

${ }^{95}$ Bevan (1902) 1.122.

${ }^{96}$ App. Syr. 11.65.
} 
viceroy, someone whom the king trusted deeply, often a relative. ${ }^{97}$ Inevitably, the personal relationship between king and viceroy did not pass on to the next generation, and, as a result, these governors tended to drift towards independence and outright rebellion after the death of the monarch who first appointed them. ${ }^{98}$ Thus with Antiochos Hierax, who was appointed by his father Antiochos II and later rebelled against his brother Seleukos II. Thus too with his replacement, Achaios, a maternal uncle of Seleukos III, ${ }^{99}$ who organised Antiochos III's succession but then drifted into rebellion against him. Had Asia Minor not been lost to the Romans in 189, the pattern might well have been repeated with Antiochos III's appointee, ${ }^{100}$ Zeuxis, whom Antiochos referred to as "father," 101 stressing the close personal relationship between them. In total, in the ninety-two year period between Seleukos I's conquest of Asia Minor and Antiochos III's loss of it, the region was actually under the control of the Seleukid monarchs for a little over fifty years, with two major intermissions and several minor ones. ${ }^{102}$

Even when Asia Minor was under royal control, that control was shaky and mostly exercised through the viceroy rather than directly. The region's distance from the major centres of royal power in Syria and Mesopotamia made it difficult to control either the viceroy or the poleis. For the king to enforce his will in person would require a major expedition, which proved difficult in several cases, ${ }^{103}$ and fatal in that of Seleukos III. Furthermore, control of the region was contested with the other kings, particularly the Ptolemies; if the Seleukid king offended a polis, it might switch sides, making it dangerous for the kings to assert their authority. ${ }^{104}$ On the other side of the equation, the poleis were old and, as a result of extended periods of foreign rule, were particularly sensitive to authority being asserted over them in unprecedented ways. As autonomous entities, they were among the most complex administrative structures in the ancient world - they could collect taxes, supply goods, and muster new troops and administrators for the king, freeing him from the need to expend time and money creating and maintaining

\footnotetext{
${ }^{97}$ Capdetrey (2007) 295.

${ }^{98}$ A persistent problem for the Seleukid dynasty: Mørkholm (1966) 103.

${ }^{99}$ Some claim that he was also an agnate Seleukid for which there is absolutely no evidence either way Grainger, for example, has taken both sides on this issue (1997) 5 vs. (2010) 68 n.30.

${ }^{100}$ In fact, the pattern seems to be an inevitable result of attempting to rule Western Asia Minor from Asia, for examples of the same pattern occur in earlier times, e.g. Cyrus the Younger under the Achaimenids, and in later times, e.g. the formation of Sultanate of Rūm under the Seljuq Turks.

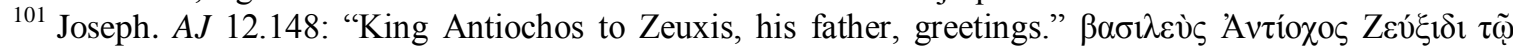
$\pi \alpha \tau \rho \grave{~ \chi \alpha i ́ p \varepsilon ı v . ~}$

102 Grainger (2002) 56.

103 Bevan (1902) 1.101.

${ }^{104}$ Billows (1995) 108; Jones (1940) 13.
} 
his own administrative structures. ${ }^{105}$ The poleis of Asia Minor also offered a less tangible commodity, the approval of Old Greece - of immense ideological importance in the contest between the Hellenistic kings, none of whom wished to be thought to have lost their Hellenicity and gone native. ${ }^{106}$ The poleis of Asia Minor were, therefore, an audience whose approval was important to the kings. ${ }^{107}$ Thus, as a result of the difficulties of controlling the region and the value of its approval for royal propaganda, Asia Minor was an atypical region, which had much to offer the kings, but which at times they struggled to command any authority over at all. ${ }^{108}$ If the kings wished to extract resources, troops, and deference from it, they had to be receptive to the particular needs and interests of its poleis. As these factors were in many ways unique to Asia Minor, the relationship between the king and the poleis of Asia Minor was also largely unique.

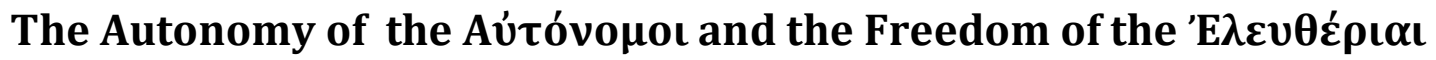

The negotiation of a relationship between the king and the poleis of Asia Minor was complicated by the assumption, shared by both parties, that a polis ought to possess

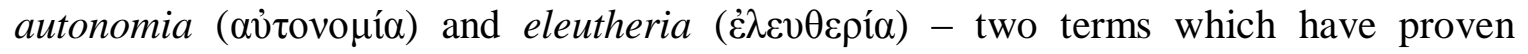
remarkably difficult to define, particularly because their meaning shifted over time. ${ }^{109}$ The word autonomia, the ancestor of our word autonomy, in the narrowest sense simply meant "the right of a city to use its own laws." ${ }^{110}$ In a wider sense, it entailed the freedom of the polis to decide for itself about the disposal of funds, control its own territory, have exclusive jurisdiction, and control of its foreign affairs. ${ }^{111}$ The closely aligned concept of eleutheria, in origin the opposite of slavery, meant freedom from any restriction on the polis' actions. It could include restrictions imposed indirectly - by debt, for example. ${ }^{112}$ In the widest definitions, it even included the right to limit the freedom of others. ${ }^{113}$ In narrower definitions, it simply signified non-subject status and could become little more

\footnotetext{
105 Bevan (1902) 1.101; Davies (2002) 6f.

106 Buraselis (1993) 259. The importance of Hellenism in the Hellenistic has often been over-stressed, particularly in the works of early scholars, but the desire of the far-flung Greeks of the Hellenistic for links back to Old Greece is clearly demonstrated by the set of Delphic maxims inscribed in the sanctuary of Kineas at Aï-Khanoum: Mairs (Forthcoming) 13.

${ }^{107}$ Bell (2004)115; Bevan (1902) 1.100.

${ }^{108}$ My presentation here is a middle ground between Bevan (1902) 1.150, for whom "[Asia Minor] was the part of their dominions to which the Seleukid kings attached the greatest value" and Sherwin-White \& Kuhrt, for whom Asia Minor while not minor, but had no special value to the Seleukid kings: (1993) 1

${ }^{109}$ Dmitriev (2005) 291.

${ }^{110}$ Idem. (2011) 118.

${ }^{111}$ Hansen (1995) 27.

112 e.g. Syll 344 l.87-88, from Teos: "so that the poleis might become free of those whom they owe" o $\pi \omega \varsigma$

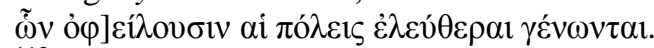

${ }^{113}$ Finley (1976) $7 \mathrm{ff}$.
} 
than a buzz-word. The flexibility of these terms was a central aspect of the relationship between kings and poleis - the poleis' autonomia and eleutheria were often maintained by shifting the definitions of the terms.

Theoretically, there was no reason why being in alliance with a stronger party should vitiate a city's autonomia, or even its eleutheria. From the time of the Peloponnesian War, free poleis had been joining larger leagues without foreseeing any impact on their status as free poleis. ${ }^{114}$ In practice, of course, completely autonomous allies were not necessarily very convenient for a league's hēgemōn. An example of this sort of objection is provided by Brasidas' exclamation on finding that Akanthos, a Spartan ally, had closed its gates against him:

If you have something else in mind or if you are going to act against your own freedom and that of the other Greeks, that would be a terrible thing. Not only would you yourselves oppose [me], but also, wherever I go on to, they will side with me less eagerly...

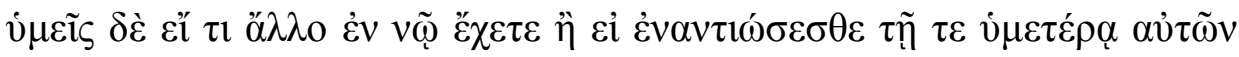

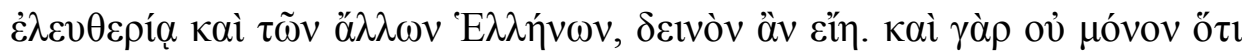

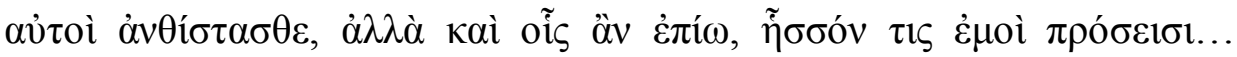
(Thuc.4.85.5-6)

Allowing subsidiary allies complete freedom was against Spartan interests - as hègemōn they wanted to be able to require their allies to help them. Brasidas' speech also shows how autonomia and eleutheria were developed in order to allow hegemones to demand obedience - by reference to the interests of the Greeks as a whole and the better interests of the polis itself. Brasidas eventually concludes that these causes will justify deploying force against Akanthos. ${ }^{115}$ Eleutheria was, thus, deployed against the polis.

Autonomia could also justify interference in the polis in order to remove a tyrant. It was frequently held that tyranny, even a tyranny chosen by the people, vitiated the right of a polis to use its own laws, since by nature tyrants overthrew and ignored the laws of the poleis they ruled. ${ }^{116}$ It was not a giant leap from there to declare, as Philip II did after Chairōneia, that the poleis' right to autonomia demanded that their laws be frozen as they

\footnotetext{
${ }^{114}$ Bosworth (1992) 122; Hansen (1995) 34.

115 Thuc. 4.87.2-3.

${ }^{116}$ Hansen (1995) 34. e.g. Arist. Pol. 5.1313a 9-10.
} 
were at that very moment - and to forbid anyone from changing them, even the polis itself. ${ }^{117}$ Protecting autonomia might even require such intensive intervention as the abolition of a polis' constitution in order to restore an ancestral one (which might never have actually existed). Alexander granted autonomia to many of the poleis of Asia but along with the grant he saw fit, in several cases, to determine what their ancestral laws were. ${ }^{118}$ SEG 35.925, for example, records his establishment of a democracy at Chios, in the course of rescuing one of his friends from local justice. In these cases, the poleis right to their own laws apparently justified making those laws for them. In 314, the diadochoi

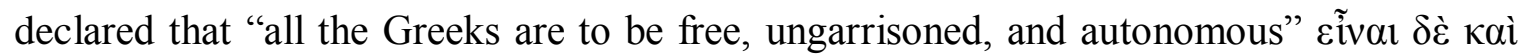

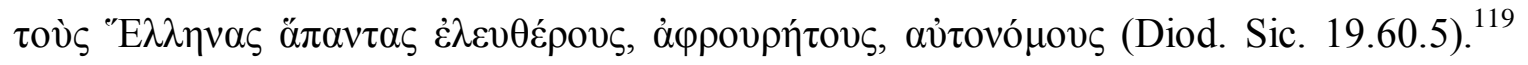
Thereafter, the freedom of the Greeks became a royal watchword, particularly for Antigonos Monophthalamos. ${ }^{120}$ Part of the reason why the kings were willing to make this sort of guarantee was that there were clear precedents that, as guarantors of the autonomia and eleutheria of the poleis, they were entitled to actively intervene in the poleis' internal affairs whenever they considered it necessary. ${ }^{121}$

So the cities of Asia Minor, which were at the core of Antigonos' domain, were thoroughly reassured of their freedom. But their freedom was definitely of the kind which was amenable to extensive royal interference - in a decree enforcing a synoikism and a constitution on Teōs and Lebedos against their wills, ${ }^{122}$ Antigonos noted, apparently without irony, that:

we are organising these things [relating to debt and grain supply]. For we think that we have made [you] free and autonomous in everything else...

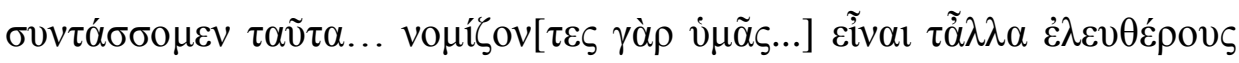

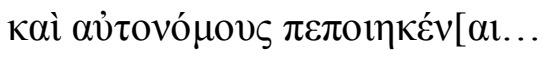

$\left(S y l l^{3} 344\right.$ l.88-89)

\footnotetext{
${ }^{117}$ Bosworth (1992) 147. Dem. On the Accession of Alexander, 8, 15.

${ }^{118}$ Carlsson (2010) 83. O’Neil (2000) 424f.

${ }_{119}$ OGIS 5, a letter from Antigonos to Skepsis reports the same event.

${ }^{120}$ Billows (1990) 189.

${ }^{121}$ Dmitriev (2011) 118.

${ }^{122}$ Ager (1991) 89, 97; Ager (1998) 6; Derow (1993) 329; Welles (1966) 25: "The many difficulties and excuses for delay show that the measure was far from popular with either city." Cf. Polyaenus, Strat. 8.57 for the homicidal rage that the Ephesians and Kolophonians bore against Lysimachos \& Arsinoē as a result of being synoikised.
} 
To Antigonos, then, utterly reconstituting the legal and physical nature of the cities of Teōs and Lebedos did not violate the poleis' eleutheria or autonomia, but was on the contrary justified by it. Moreover, Antigonos, Lysimachos, and finally Seleukos, all used the chaotic warfare of the times to justify acts that were universally agreed to violate autonomy, such as installing garrisons and extracting tax. ${ }^{123}$ After the wars were over, and Asia Minor was in Seleukid hands, the Gallic invasion occurred, then the Syrian Wars, and, somehow, the garrisons never left and the taxes never ended. ${ }^{124}$

\section{Royal Cults}

In many of these poleis, the kings were honoured not as overlords but as gods with their own dedicated cults, altars, and priests. The civic cults for the kings in the cities of Asia Minor were distinct from other royal cults. Civic cults were granted and administered by the cities and are attested from the very beginning of the Hellenistic Period, whereas royal cults were propagated by the kings and are first attested later. In the Hellenistic period, these civic cults were an exclusively Greek phenomenon, mostly attested in Asia Minor. ${ }^{125}$ They were, as discussed above (page 6), a development which the kings were clearly amenable to, since being compared with the divine both legitimated their power and flattered their egos.

However, treating the king as divine was also in the interest of the poleis. Because kings were a new phenomenon, the poleis had no precedent for how to interact with them. ${ }^{126}$ Having promoted the king to the status of a god, the poleis could use their interactions with the gods as a model for how to interact with the king. ${ }^{127}$ From the polis' perspective, interactions with the gods were a useful model because acknowledging the polis' subservience to the gods, and the gods' right to receive tribute from the polis was not mutually exclusive with the polis having autonomia and eleutheria - even the freest poleis had these obligations. ${ }^{128}$ On the contrary, being able to offer wealth to the god was

\footnotetext{
${ }^{123}$ Billows (1990) 231; Lund (1992) 116; Bevan (1902) 1.122.

${ }^{124}$ By the time Livy wrote, the disconnect between declaring a place free and garrisoning troops in it was not even noted: "[Q. Antonius] restored their city, fields and laws to them, and since winter was now taking hold, he chose the harbour of Phocaea for wintering of the fleet." urbem agrosque et suas leges iis restituit; et, quia hiems iam appetebat, Phocaeae portus ad hibernandum classi delegit (Livy 37.32.14)

${ }^{125}$ Sherwin-White dismisses the idea of a civic ruler cult in Babylon: (1984) 161. Linssen is more equivocal (2004) 125ff. Either way, this would probably be better understood as a third distinct type of ruler cult.

${ }^{126}$ Cf. Mitchell (1997) 164ff. for an analysis of how Athens utterly failed to work out how to interact with Philip II. Unlike the archaic tyrants who could b understood as a type of aristocrat: Price (1984) 25.

${ }^{127}$ Price (1984) 30.

${ }^{128}$ Bevan (1901) 632; Ehrenberg (1969) 76.
} 
a sign of the polis' prestige. ${ }^{129}$ Moreover, the poleis were used to having a beneficial relationship with the gods, ${ }^{130}$ in which the gods were expected to be efficacious, repaying worship with supernatural or financial support in times of trouble ${ }^{131}-$ money from the temple treasuries could be appropriated to meet expenses (as a loan) ${ }^{132}$ and if no one could afford to serve in an expensive magistracy, the patron god could be enlisted. ${ }^{133}$ The priests represented god and polis to each other with little power over either, ${ }^{134}$ in much the way the Hellenistic royal philoi were to mediate between king and polis. The use of the analogy of king with god, granted the kings a claim on the poleis' income and resources, but also imposed the obligation to interfere rarely and to support the polis in times of trouble. The clearest example of this dynamic seems to be the Athenians' interactions with Dēmētrios I Poliorkētēs, to whom the Athenians granted a residence in the Parthenon. ${ }^{135}$ The Athenians' (in)famous Ithyphallic hymn, just like a normal hymn to a god, welcoming Dēmētrios to the city, praises him, indirectly encourages him to be efficacious in general, and then makes a specific request - that he attack the Aitōlians. ${ }^{136}$ Seleukos received similar treatment, for a fragmentary inscription of a similar ithyphallic hymn addressed to him was found at Erythrai. ${ }^{137}$ These civic cults remained a central part of the poleis' interactions with the king throughout the Hellenistic Period, but increasingly those interactions were part of a new and unique form of relationship.

\section{The Relationship between Kings and Poleis in Seleukid Asia Minor}

The relationship which the kings and the poleis developed was a peculiar one, and its exact details remain the subject of scholarly debate. The usual model for the relationship between the king and polis in the Hellenistic was first formulated by A.H.M. Jones in The Greek City (1940). ${ }^{138}$ According to Jones' model, the kings had complete control of the cities and could crush them with their armies if the cities acted up. But, Jones argued, the king chose to maintain the illusion that the cities were his autonomous allies, not his

\footnotetext{
${ }^{129}$ Potter (2003) 414.

${ }^{130}$ Burkert (1995) $202 \& 206$.

${ }^{131}$ Chaniotis (2003) 433; idem (2011) 181. Antiochos II's efficacy as a liberator seems to have been responsible for Miletos hailing him $\theta \varepsilon o ́ c:$ Parke (1985) 57.

132 Kallet-Marx (1994) 232.

133 Sherk (1991) 229.

${ }^{134}$ Bremer (2012) 220; Horster (2012) 11.

135 Plut. Demetr. 23.3.

${ }^{136}$ Ath. 253C-F; Diod. Sic. 20.46 \& Plut. Demetr. 10-13; Chaniotis (2011) 173 \& 181.

${ }^{137}$ I. Erythrae 205.

${ }^{138}$ Although foreshadowed by Bevan (1902) 1.124 \& Rostovtzeff (1941) 3.1347 n.15.
} 
subjects, because he preferred to have his army free and bore a soft spot for the Greeks as his kinsmen. ${ }^{139}$ Therefore, the kings presented themselves not as ruling by force, but as a benevolent friend, ally, and donor - to whom, implicitly, the poleis were deeply indebted. ${ }^{140}$ Such circumlocutions were not necessarily new - P. Low has recently argued that even the relatively naked empire of the Athenians sometimes employed such diplomatic language in its interactions with its subject allies. ${ }^{141}$

A.H.M. Jones' model has not gone unmodified in the past seventy years, however. Recently, several critiques have appeared, mostly concentrating their criticism on the illusion aspect of Jones' hypothesis. Typical of this trend is Carlsson's (convincing) argument that the poleis continued to operate democratically; i.e., they were autonomous in the most literal sense, at least until the arrival of Rome in the region. ${ }^{142}$ The most recent major appraisal of the relationship between king and polis, John Ma's Antiochos III and the Cities of Western Asia Minor also takes this tack, using speech-act theory to stress the agency of the poleis in an ongoing negotiation of status. ${ }^{143}$ According to Ma, the poleis worked to maintain a degree of agency, by, for example, incorporating the king into their political and ideological structures. ${ }^{144}$ Their leverage was the fact that the king ultimately needed the poleis to acknowledge him as sovereign in order to actually be sovereign. This acknowledgement could only be obtained by maintaining the illusion that the poleis remained autonomous, which required the kings to actually treat the poleis, most of the time, as if they were autonomous. Thus, Ma's position significantly alters the tenor of Jones' model.

The Jones-Ma model is largely based on close analysis of inscriptions from the poleis of Western Asia Minor. Increasing sophistication in the way in which scholars interpret these inscriptions is largely responsible for the changing evaluation of the relationship between king and poleis. In the past, it was sometimes assumed that epigraphic evidence, unlike the literary record, was true primary evidence and could therefore be taken at face battle. In some ways this is true - inscriptions accurately reflect political decisions of poleis and kingdom, insofar as they are the actual decrees and edicts

\footnotetext{
139 e.g. Jones (1940) 111.

${ }^{140} \mathrm{Ma}(1999) 199$.

${ }^{141}$ Low (2005)

${ }^{142}$ Carlsson (2010).

${ }^{143} \mathrm{Ma}(1999)$ 158ff.; Shipley (2000)78;

${ }^{144} \mathrm{Ma}$ (1999) 227ff.; foreshadowed by Billows (1995) 75: "[it] should not be overlooked: that the cities in turn manipulated the kings."
} 
which resulted from those decisions. Because of their immediacy to the events they describe, inscriptions are less likely to be mistaken on matters of fact, ${ }^{145}$ though they might misrepresent them and they may leave out important matters which were obvious to their audience. ${ }^{146}$ Epigraphic evidence is not unbiased. ${ }^{147}$ Inscriptions represent the final, official, view of the decisions they record - their orders might not have been carried out, their claims might not have been sincere, and, ultimately, they reflect attitudes, not completely objective facts. ${ }^{148}$ The negotiations which led to an agreement are entirely obscured - identical inscriptions would be produced by a decision reached by genuine negotiation and by a decision imposed on a polis but presented as negotiation. ${ }^{149}$ Moreover, since the idea that the polis was free was important to civic pride and royal reputation, both the polis and the king had a vested interest in presenting a given city as a self-governing polis, regardless of whether that was the reality. ${ }^{150}$ Pursuant to this, poleis in Asia Minor seem to have avoided inscribing letters from the king, other than royal grants, which were inscribed as proof of grants. ${ }^{151}$ Thus, the main evidence in the discussion of the independence of the poleis is not a neutral record, but on the contrary, works to present a certain position on that very issue. Inscriptions must, therefore, be approached critically.

\section{An Exemplar: OGIS 223}

Thus, discussion of the Jones-Ma model requires careful analysis of the epigraphic material. OGIS 223 is an entirely typical example of the sort of inscription that the JonesMa model is based upon. It is an inscription from Erythrai (modern Litri in Western Asia Minor), originally inscribed in the time of Antiochos II (281-246). Erythrai had sent an embassy to Antiochos, with gifts, to ask him for privileges - perhaps at the time of his accession to the throne. He was persuaded and the Erythraians inscribed his response, which granted the Erythraians autonomy and tax-free status, on a stele. This background demonstrates the degree to which the poleis were active agents in the relationship - the interaction between king and polis was apparently initiated by the Erythraians, their envoys presented the polis' gift, flattered the king, emphasised the positive examples of

\footnotetext{
145 Cook (1987) 7-8; Walbank (1984a) 11.

${ }^{146}$ McLean (1972) 2.

${ }^{147}$ Bagnall \& Derow (2004) xxv-xxvi.

${ }_{148}$ Bodel (2001) 46f.; Woodhead (1967) 4.

${ }^{149} \mathrm{Ma}(1999) 21 \mathrm{f}$.

${ }^{150}$ Carlsson (2010) 18.

${ }^{151}$ Roueché \& Sherwin-White (1985) 34.
} 
his predecessors (presumably in the hope that he would imitate them), and presented the legal case for Erythrai's autonomy and exemption from tax. The king's role was largely reactive. Significantly, however, he reacted to the polis directly, which was not how he generally interacted with his subjects - in most cases the king sent orders down the chain of command and received reports in the same way. ${ }^{152}$ Not so with cities like Erythrai they apparently expected and merited direct royal attention. This attention reflects the close, personal relationship (or, at least, the appearance of one) which the king strove to maintain between himself and the Erythraians.

An essential part of this close personal relationship was the effort that the king's letter expended to conceal the power imbalance between the king and the city. When Antiochos announced his acceptance of the city's gifts, he said:

We have indeed accepted the honour and the crown, as is proper, and likewise also the presents, and we applaud you for being grateful in everything...

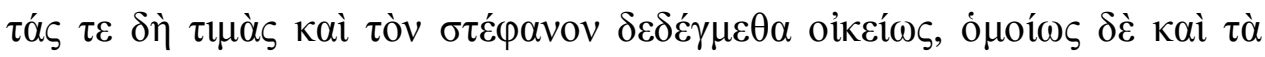

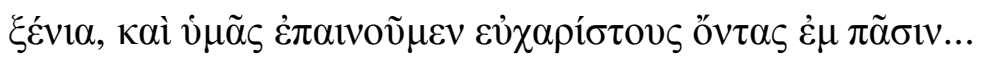

(OGIS 223 l.13-14)

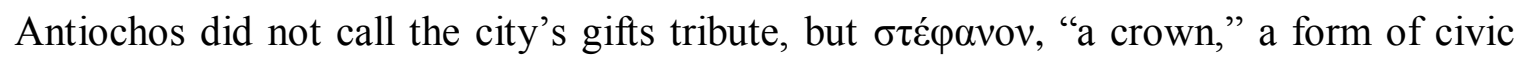
honour, and $\xi \dot{\varepsilon} v 1 \alpha$, gifts implying a friendly relationship with mutual duties. He thereby presented their relationship as one of friendship, in which the cities honoured the king rather than submitted to him. Since a relationship of this sort was exactly what the Erythraian envoys were seeking to have acknowledged, it seems likely that these were the terms which they had used for their gifts - in which case both parties were complicit in representing their relationship in this way. That the relationship between king and polis is a voluntary friendship was further emphasised by the way in which the king carefully phrased his wishes to avoid giving orders. This practice can be seen in Antiochos' use of phrases like "we encourage you to be mindful that" $\pi \alpha \rho \alpha \kappa \alpha \lambda o \tilde{v} \mu \varepsilon v \quad \ldots$ v $\mu \tilde{\alpha} \varsigma$

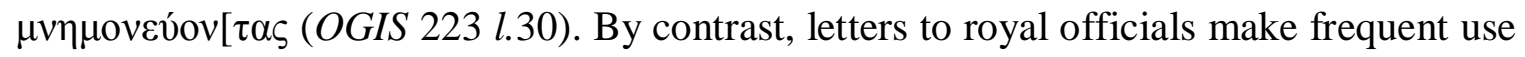
of imperatives - in a letter organising a land transfer near Kyzikos, for example, Antiochos II tells his official Mētrophanēs, “arrange to hand Laodikē's property over to

${ }^{152}$ Walbank (1984b) 71. cf. Hefzibah. 


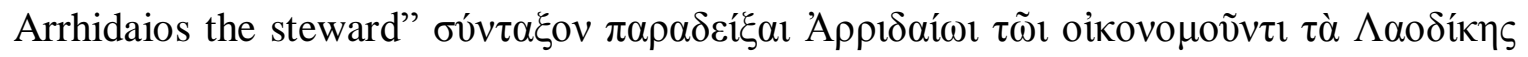
(OGIS 225 l.20), with an aorist imperative. ${ }^{153}$ Such imperatives are exceptionally rare in letters to the poleis of Asia Minor. ${ }^{154}$

On the other hand, the manner in which the king acknowledged the Erythraians' gifts also served to reinforce his superior position by emphasising the symbolic signification of the gifts - the special relationship he had with the city - rather than their economic value. The inscription carefully presents a relationship in which the city offers

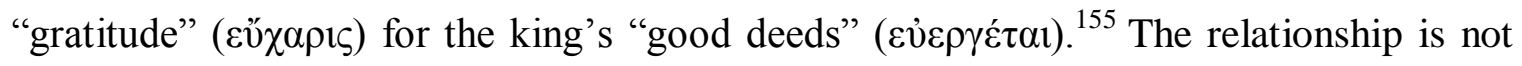
an equal one - Antiochos applauds the Erythraians for their gift, but he is not grateful. He gives no indication that he needs anything from Erythrai. Mitchell argues that the monarchies of the Persians and of Alexander were based on constantly doling out gifts to subordinates, so that they remained eternally indebted to the monarch. ${ }^{156}$ OGIS 223 is an excellent example of how this system of benefaction was a central part of the Hellenistic kings' relations with their subjects, too. ${ }^{157}$ Antiochos II, having received gifts from Erythrai, reciprocated with guarantees of privileged status, tax-exemptions, and autonomia - boons which the Erythraians could never repay. ${ }^{158}$ Thus, Antiochos established and maintained an uneven relationship in which he was the benefactor par excellence, ${ }^{159}$ and the Erythraians were his beneficiaries, honour-bound to support him. ${ }^{160}$

Evidence from Polybios suggests that contemporaries also interpreted this sort of interaction in this way. According to him, when, before the Syrian War, the Romans demanded that Antiochos III set free the poleis of Asia Minor, Antiochos responded that:

The autonomous poleis in Asia must not achieve freedom (eleutheria) through Roman command, but through his [i.e., Antiochos II's] own grace.

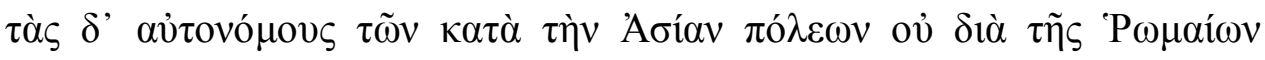

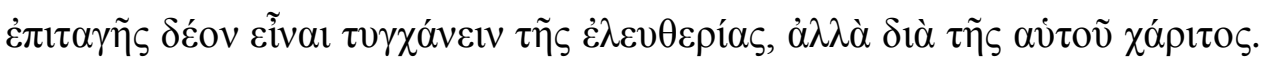

(Polyb.18.51.9)

\footnotetext{
153 cf. also Hefzibah l.2 \& 34.

${ }^{154}$ Ehrenberg (1969) 166.

$155 \mathrm{Ma}(1999) 185 \mathrm{ff}$.

156 Mitchell (1997) 172ff.

${ }^{157}$ Bringmann (1993) 24; idem (2001) 206; Parke (1985) 57; Walbank (1993) 120.

158 These grants have a potential parallel with the Assyrian grants of privileges (kidinnūtu) to Mesopotamian cities, analysed by Van De Mieroop (1997) 136ff.

${ }^{159}$ Erskine, (1994) 71.

${ }^{160}$ Capdetrey (2007) 212; Ma (1999) 153; Shipley (2000) 73.
} 
As Polybios has Antiochos present it, ${ }^{161}$ both parties wanted the cities of Asia Minor to be free - but it was vitally important to Antiochos that he be the emancipator. Raaflaub suggests that the newly freed cities would be considered free in the same way that freed slaves were - they would certainly have more rights, but an enormous obligation would remain. ${ }^{162}$ They could hardly support Rome or Pergamōn against the king who had freed them, which is why Polybios had Antiochos stress that the grant of freedom must come from him. Ironically, by freeing the Iōnian cities, Antiochos III would assert his sovereignty over them. This idea dominated the interaction between kings and poleis and stands behind much of the royal beneficence.

\section{Civic Status in Practice}

Since, despite their literal meaning, grants of autonomia and eleutheria could indicate a polis' dependence on the king, the relationship presented in the inscriptions does not necessarily reflect the degree of autonomy which the poleis enjoyed in reality. Whether they were highly autonomous or entirely dependent is contentious. Central to Jones' original formulation of the relationship between kings and poleis was the opinion that "the kings did all in their power to rob the cities of any effective means of rejecting [royal] advice," 163 and thus, in practice, the free cities were hardly different from the unfree ones. ${ }^{164}$ There is substantial evidence to support the idea that the Hellenistic kings' grants of freedom could be hollow. The clearest example is the omnipresence of royal garrisons. When Antiochos III arrived in Asia Minor to free the local cities:

The majority sided with him and let in his garrisons because of their fear of conquest, but the Smyrnaians, Lampsakans, and others still held out.

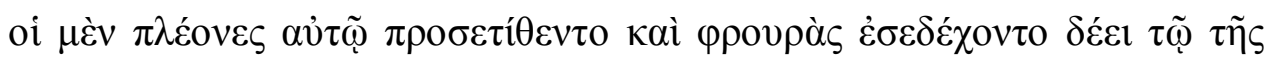

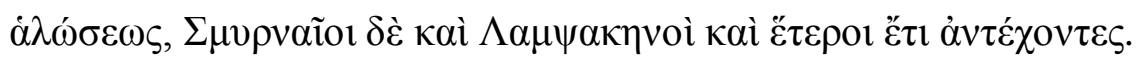

(App. Syr.1.2)

In addition to placing the poleis deeply in the king's debt, being freed by Antiochos apparently involved receiving a royal garrison. A polis with a royal garrison could not,

\footnotetext{
${ }^{161}$ There is good reason for thinking that, like many historical speeches, Antiochos' words reflect what Polybios thought that he ought to have said, rather than what he actually said: Grainger (2002) 93-95. This makes no difference to my argument.

${ }^{162}$ Raaflaub (2004) 171.

163 Jones (1940) 111.

${ }^{164}$ Ibid. 102.
} 
realistically, act independently of the king - even if the garrison did not actively interfere on the king's behalf, its passive influence would act as a check on the polis' freedom of action. The Smyrnaians and the Lampsakans wanted nothing of this kind of freedom.

The grants of autonomy themselves provide another indication that autonomia did not mean as much as it once had. When the king recognised the autonomy of cities, he often granted other freedoms as well, which ought to have been implicit in autonomous status but, apparently, no longer were. In the letter to Erythrai, for example, Antiochos declares that:

Since those with Tharsynōn, Pythēs, and Bottas demonstrated that your polis was autonomos and free from tribute under Alexander and Antigonos, and that our ancestors always pursued this ... we will carefully guard your autonomia and we agree for you to be exempt from all the other tributes and from the anti-Gallic levies.

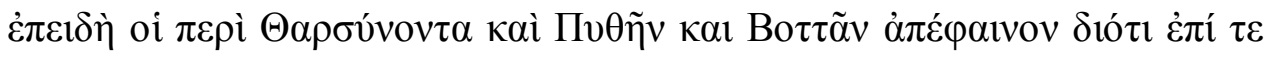

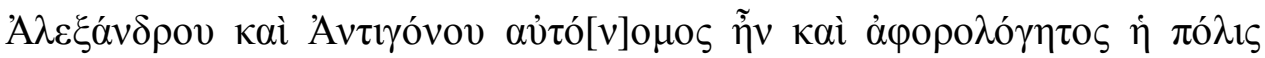

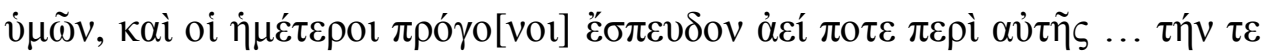

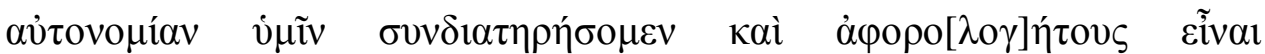

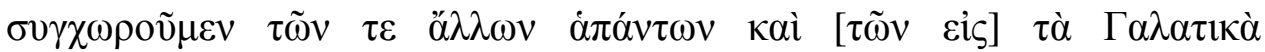

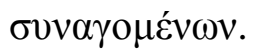

(OGIS 223 l.21-28)

In this inscription, Antiochos was, ostensibly, not granting autonomy, but recognising a

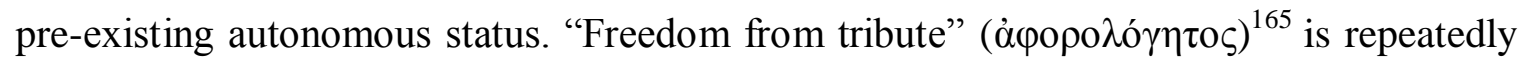
noted as separate from autonomy - though Erythrai was and allegedly had long been both, it was conceivable to the Erythraian envoys and the king for a polis to be autonomous without being exempt from tribute. Yet "tribute" ( $\varphi$ ópos) had been associated with vassal status since the Peloponnesian War and represented a real block on a polis' ability to dispose of its funds as it pleased - a central aspect of autonomia. ${ }^{166}$ Further, the king specifically freed the Erythraians from an obligation to supply him with troops - again, apparently, such an obligation could have been imposed on a polis with autonomia. Thus, OGIS 223 provides an example of how the term autonomia was increasingly restricted to

\footnotetext{
${ }^{165}$ Welles (1966) 319.

${ }^{166}$ Raaflaub (2004) 137; Ma (1999) 154f.
} 
its narrowest meaning - the right of the polis to its own laws. By the 250s it seems to have become so depreciated in value that it ceased to be used. ${ }^{167}$ Thereafter, royal grants either specify the exact exemptions which they grant or refer to eleutheria, often in

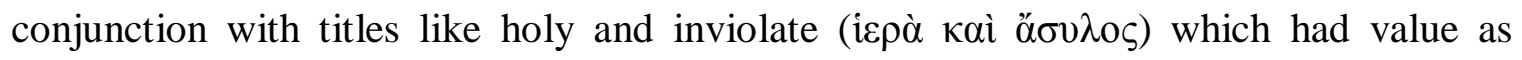
prestigious honours, but little if any practical significance. ${ }^{168}$ Grants of immunity from taxation were exceedingly rare, ${ }^{169}$ so if freedom from tribute were understood as a central part of autonomia, very few of the poleis of Western Asia Minor had autonomia.

This dismal picture of the practical freedom of the cities of Asia Minor flows from contrasting the wide theoretical definitions of autonomia with a narrower practical reality. However, even Jones accepted that the poleis of Asia Minor, though limited by the king, retained polis-style governments with a substantial amount of control over their internal administration and, thus, autonomia according to the narrower, more literal definitions. ${ }^{170}$ Poleis continued to possess their own laws, under which they were managed by assemblies, boulai, and collections of magistrates ${ }^{171}$ - Nawotka's study of Milētos demonstrates the type of complex civic constitution which continued to operate. ${ }^{172}$ At least in terms of their epigraphic output, polis organs of self-government appear to have been busier than ever. ${ }^{173}$ The exact degree to which the internal affairs of the polis were carried out independently of the king remains contentious, as does the degree to which the ostensibly democratic governments of the poleis were dominated by the civic elites. ${ }^{174}$ But the basic fact that the poleis of Asia Minor retained competence over their internal affairs is widely accepted. ${ }^{175}$ Since internal matters were most of the business of the poleis, this was probably the most important form of freedom to the poleis. But it is increasingly apparent that polis autonomy could also extend beyond internal self-government into the interstate relations and military affairs which were important to wider definitions of autonomia and eleutheria. ${ }^{176}$

\footnotetext{
${ }^{167}$ Carlsson (2010) 98.

${ }^{168}$ Rigsby (1996) 22.

169 Bikerman (1938) 148

${ }^{170}$ Jones (1940) 48.

${ }^{171}$ Dmitriev (2005) 13-15.

${ }^{172}$ Nawotka (1999) esp.130-171. They are well-attested in the Roman period too and even into Late Antiquity: Hansen (2006) 50.

${ }^{173}$ Dmitriev (2005) 32-33.

${ }^{174}$ Green (2007) xx; Hansen (2006) 132; Jones (1940) 166; Ostwald (2000) 390.

175 e.g. Billows (2003) 211; Parke (1985) 64; Shipley (2000) 3; Walbank (1992) 136.

176 e.g. Carlsson (2010); Ma (2000a).
} 


\section{Independence in Foreign Affairs}

Even historians who see Seleukid rule as light and essentially benevolent usually hold that it meant the end of independent foreign policies for the poleis. ${ }^{177}$ However, to a limited degree, the poleis of Asia Minor continued to interact with other poleis independently of the Seleukid monarch. Some poleis in Asia Minor maintained some form of foreign policy, at least some of the time. They formed and reinforced direct links with other poleis, stressing and reinforcing kinship links, arbitrating disputes, granting honours like asylia, and forming leagues, in much the same manner as free poleis would.

Poleis often sent envoys to each other, independently of the king - one particularly well-attested example is OGIS $233 .{ }^{178}$ This inscription records Magnēsia-onthe-Maiandros' establishment of quinquennial crown games for their local manifestation of Artemis and the result of a mission to Antiocheia-in-Persia, inviting them to adopt the

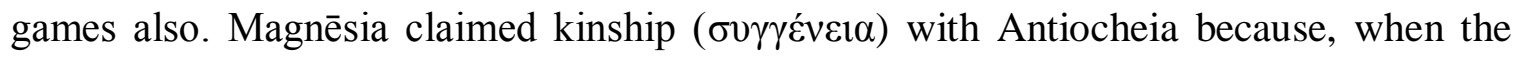
king had requested colonists for its foundation, they had contributed "enthusiastically to

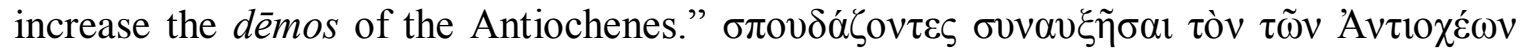
$\delta \tilde{\eta} \mu \mathrm{ov}$ (OGIS 233 l.20). Kinship between poleis was generally understood as colonial ties (whether real or mythical) ${ }^{179}$ and the Magnēsians were conforming to the traditional

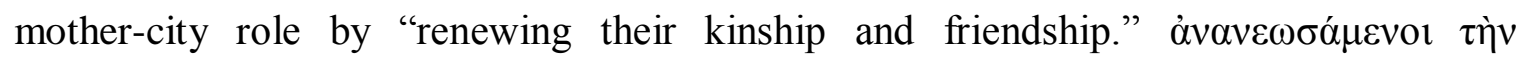

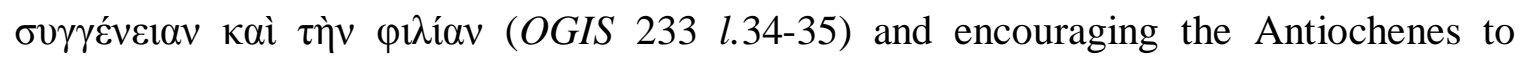
recognise their goddess and her games. The end of the inscription lists several other cities in Seleukid Mesopotamia and Iran which the Magnēsians contacted in a similar manner, including Seleukeia-on-the-Tigris and Seleukeia-on-the-Eulaios (Susa), ${ }^{180}$ demonstrating that this was a wide-ranging effort at building inter-polis relationships, apparently conducted independently of the king and his administration. Magnēsia's freedom in foreign affairs was not limited to interactions within the kingdom; Syll 560 records a similar Magnēsian embassy concerning the games for Artemis which was dispatched to Epidamnos in Illyria. Though this embassy used different points to make their case, emphasising the games' approval by Delphian Apollo rather than kinship through colonisation (obviously inapplicable to Doric Epidamnos), the decree is otherwise extremely similar to that which resulted from the mission to Antiocheia-in-Persia (OGIS

\footnotetext{
177 e.g. Grainger (2002) 58.

${ }^{178}$ Bikerman (1938) 142.

179 Jones (1999) 14 \& 60.

${ }^{180}$ Presumably, therefore, their citizens had been called upon to settle in those poleis, also.
} 
233), which suggests that both missions presented essentially the same case in essentially the same way. In both cases, three envoys (OGIS 233 l.31-32; Syll 560 l.5-6) explained

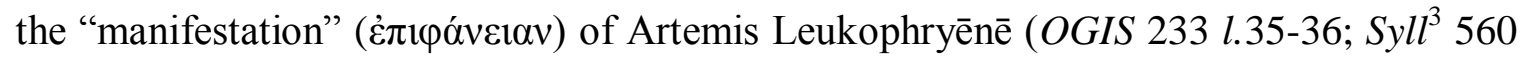
l.8), Magnēsia's connection with the target polis in particular (OGIS 233 l.14-20; hints of this at $\left.S y l l^{3} 560 l .3 \& 21\right)$ and the good things they had done for the Greeks generally (OGIS 233 l.20-25; Syll 560 l.8-14), with more emphasis on the former at Antiocheia-inPersia and on the latter at Epidamnos (probably reflecting the fact that there was little specific connection with Epidamnos to emphasise). This was followed by a request pursuant to a decree from Apollo at Delphi (OGIS 233 l.39; Syll 560 l.16-17), for the target polis:

"to recognise the sacrifices, festivities, holiday, and the Pythian-grade crown games in arts, athletics and horsemanship, which the Magnēsians celebrate for Artemis Leukophryēnē."

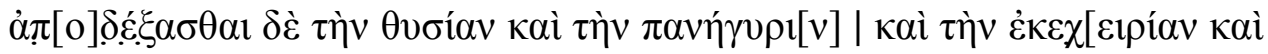

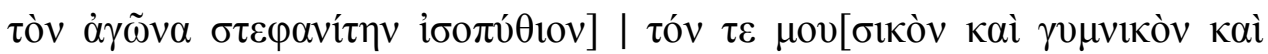

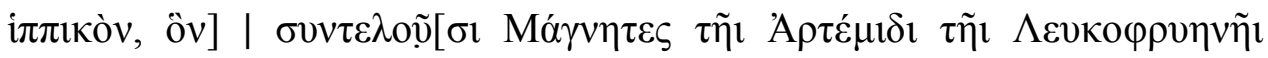
(OGIS 233 l.56-60)

Compare $S y l l^{3} 560 l .19-21,28-30$, which uses very similar wording. The image is of two missions sent out with very similar briefs and conducted in a very similar manner. Thus, the form of Magnēsia's interactions with poleis inside and outside the Seleukid sphere was much the same. ${ }^{181}$

Grants of asylia, another mainstay of Hellenistic civic interaction, support this conclusion. Between c.260 BC and AD 23, poleis throughout the Greek world regularly appealed to other poleis, kings, and the Romans to recognise their cities or their

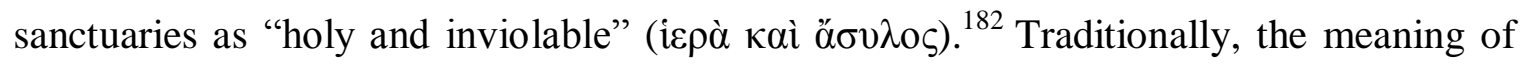
these grants has been difficult to pin down. Some argued that being named holy and inviolable granted freedom from arrest to those who made it to the city's altar. ${ }^{183}$ Others

\footnotetext{
${ }^{181}$ The Magnēsians did not limit their interactions in this matter to poleis, either. They requested and received recognition of the Pythian status of their games from Antiochos III (OGIS 282), Ptolemaios IV (RC 33), and Attalos I (OGIS 282).

182 Rigsby (1996) 3.

${ }^{183}$ Bikerman (1938) 149 \& Welles (1966) 53f.. on the basis of I.Macc.10.43, in which a fugitive seeks sanctuary at an altar but is nevertheless slaughtered by royal forces.
} 
argued that asylia marked a state off-limits to military depredation and piracy. ${ }^{184}$ Rigsby argues that the Hellenistic Greeks themselves had no consistent idea of what these titles meant, and that they were usually contradictory or redundant - a city's temples were, by definition, already holy and inviolable, and in practice no one seems to have displayed special compunction against violating the territory of poleis with asylia. He argued that the primary purpose of grants of asylia was honorific - to be recognised as asylos was to be recognised as important on the international stage. ${ }^{185}$ These grants regularly ignore the boundaries between the Hellenistic kingdoms. Kōs, for example, received recognition of its asylia from six different kings and thirty-six poleis in 242 (while a Ptolemaic vassal), including places like Naples, for which matters of asylum and depredation were unlikely to arise. ${ }^{186}$ There was great prestige for Kōs in receiving recognition from a figure as powerful and busy as the king, but there was also great prestige in receiving recognition from distant poleis like Naples, which suggested that Kōs' fame was widespread. Grants of asylia, therefore, provide an example of how poleis' foreign relations continued to cross kingdom boundaries.

The poleis could also operate on the international stage in more significant political matters, but the degree of independence they had in these matters is less clear. An example is provided by $S y l l^{3} 560$ 's praise of the Magnēsians for:

... the good deed which they carried out for the League of the Cretans [by] putting an end to the internecine war...

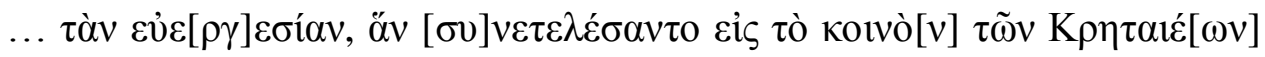

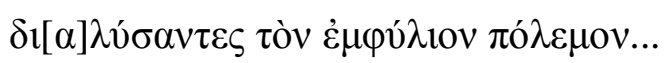

$\left(S y l l^{3} 560 l .10-12\right)$

Ager interprets this as a reference to peaceful arbitration of inter-polis disputes. ${ }^{187}$ The submission of conflicts to arbitration was one of the cornerstones of Hellenistic international relations - Ager's comprehensive compilation contains 171 attempted arbitrations between the 338 and 90 BC. ${ }^{188}$ In this process, the arbitrator chosen was usually a neutral power with enough prestige and power that its ruling would be respected

\footnotetext{
${ }^{184}$ Burkert (1995) 210.

185 Rigsby (1996) 20-23.

${ }^{186}$ Rigsby (1996) 112-153.

187 Ager (1996) 161.

${ }^{188}$ Ibid.
} 
by both parties - often one of the kings or the Romans. Magnēsia must have had significant prestige for the Cretans to accept it as an arbitrator, which is not consistent with Magnēsia being viewed by third parties as a subject community with no freedom in foreign affairs. ${ }^{189}$ Sometimes kings, when asked to arbitrate disputes, were willing to delegate the matter to subordinates, including subject poleis ${ }^{190}$ - that may be what happened in this case. However, arbitrating personally allowed a king to begin the cycle of beneficence and the enforcement of his decision gave the king a justification for further interference in the poleis' affairs. ${ }^{191}$ As Crete sat loosely within the Ptolemaic sphere at this time and arbitrating personally would have offered the Seleukid monarch the opportunity to bring Crete into his own sphere, it seems unlikely that the Seleukid king would have passed up the opportunity to arbitrate personally, if Eleutherna and the Cretan League had requested arbitration from him. Alternatively, the appeal may have come at a time when the Seleukid king was unwilling to antagonise the Ptolemies, but in that case it would be strange for the Cretans to approach the Seleukid king at all. Thus it seems likely that the Cretans approached Magnēsia directly and that they believed that it had sufficient independence in foreign affairs to respond. They thereby received an arbitration from a power which they could respect, without giving the Seleukid king a foothold on Crete.. There are more examples of subject poleis arbitrating - around 200 BC, a conflict between Hermionē and Epidauros was decided jointly by Milētos, subject to Antiochos III, and Rhodes, which was de jure and de facto independent, but allied to Rome. ${ }^{192}$ In this case, however, the two arbitrators were probably chosen so that the arbitration would have the backing of both of the major powers in the Aegean. Rhodes was frequently useful to the Romans as a proxy in matters of this sort, principally because it had a largely autonomous foreign policy. If Milētos was the Seleukid analogue, it might have enjoyed a similar degree of freedom in its foreign policy also. These two arbitrations thus provide evidence that, at times, the poleis of Asia Minor were able to interact with states outside the Seleukid realm in the manner of independent poleis, but especially in the latter case, the degree to which this interaction was actually conducted independently of the king is unclear.

\footnotetext{
${ }^{189}$ Dmitriev (2011) 105.

${ }^{190}$ Billows (1990) 232.

${ }^{191}$ Carlsson (2010) 110.

192 Ager (1996) 170ff.
} 
Some of the poleis in Western Asia Minor even organised themselves into leagues. The best attested of these is the Iōnian League. Leagues could be tools for royal control: ${ }^{193}$ the various incarnations of the Hellenic League established by the Tēmenid and Antigonid kings were intended to work this way; ${ }^{194}$ the Ptolemaic League of the Islanders actually did. ${ }^{195}$ However, leagues were not necessarily instruments for external control; they often took on polis-like characteristics, but, being larger, were far more capable of countering royal power, ${ }^{196}$ especially when they were able to rally their constituent poleis with common ethnic, religious, political, or historical traditions, as in the case of the Achaian and Aitōlian Leagues in Mainland Greece. ${ }^{197}$ The Iōnian League certainly had the potential to call on such traditions - it was a revival of the ancient religious and ethnic union of the Dōdekopolis, which had had met at the Paniōnion since the ninth century. ${ }^{198}$ That the League maintained an institutional identity separate of the king is suggested by OGIS 222, a decree issued for Antiochos I's birthday:

In order that [King Antiochos and] Queen Stratonikē [may] know [the goodwill of the league] of the Iōnians from these honours...

And [the League] will inscribe on a stele both this decree and the names and patronymics of the synedroi who came from the poleis and set it up in the sanctuary near the altar of the kings.

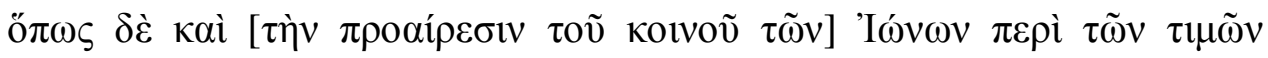

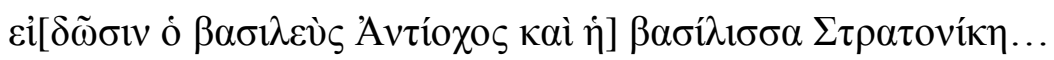

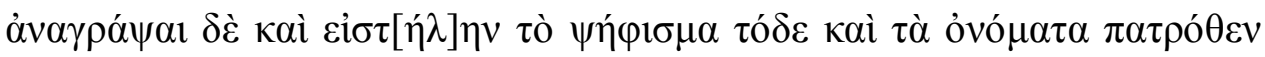

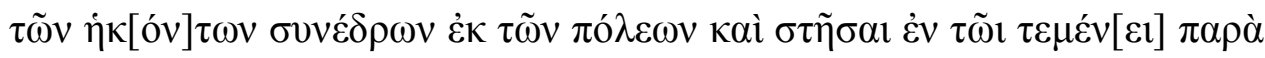

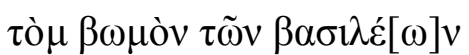

(OGIS 222 l. 6-8; 40-43). ${ }^{199}$

On the one hand, this decree suggests a League with substantial independence. The League refers to its decree as a psêphisma - the same term used to refer to polis decrees,

\footnotetext{
193 Jones (1940) 102; Rostovtzeff (1941) 1.154; Shipley (2000) 133, 139.

${ }^{194}$ Dmitriev (2011) 75-90.

195 Bagnall (1976) 156.

${ }^{196}$ Carlsson (2010) 106; Davies (2002) 10; Hammond (1951)30.

${ }^{197}$ Walbank (2000) 20ff.

${ }^{198}$ Roebuck (1959) 30.

${ }^{199}$ Piejko (1991) updates the reconstruction of this decree significantly, but these passages are unaffected.
} 
indicating that the League had taken on polis-like characteristics. Further, the League has its own councillors, the synedroi, who represent the individual poleis and are listed by name at the end of the decree. The decree makes no mention of any royal official overseeing the League's meetings as the nēsiarchos did in the League of Islanders (which was definitely under royal control). ${ }^{200}$ Together, these items suggest a large selfgoverning organisation, able to direct itself as it wished. On the other hand, the subject matter of the decree and the reference to an altar of the Seleukid kings in the League's sanctuary, do not imply that the League exercised great independence from the kings. ${ }^{201}$ There do not seem to be any later attestations of the League either, which might be an accident of preservation, but could indicate that it lapsed or was suppressed.

Scanty evidence relating to the Chrysaorian League in Karia, suggests that Leagues' relationships with the monarch could change over time. Under Antiochos I and II, the Chrysaorian League seems to have been subservient to the kings; during their reigns one of the League's centres, Alabanda, was renamed Antiocheia-of-theChrysaorians and a new foundation, named Stratonikeia after the Seleukid queen, ${ }^{202}$ was placed in charge of the League's main cult centre. ${ }^{203}$ After their reigns, however, when Seleukid power in Asia Minor waned, the League was maintained, presumably by the Chrysaorians themselves. It is hard to believe that the Chrysaorians would have done this if the League were simply a mechanism for royal control - compare the rapid disappearance of the League of Corinth after the death of Alexander. When strong royal power returned to Asia Minor under Antiochos III, the League's poleis were split between the Seleukid and Rhodian spheres, with its cult centre in Rhodian territory, but the League continued to be active ${ }^{204}$ - presumably independently of the Seleukid kings, or one would expect the Rhodians to have removed their cities from it. ${ }^{205}$ Thus, it seems that Leagues in Asia Minor could relate to the king in much the same way as individual poleis could - potentially subservient to, potentially independent of, the royal will. As they contained and organised multiple poleis, however, they potentially stood in a stronger position relative to the kings.

\footnotetext{
${ }^{200}$ Merker (1970) 157.

${ }^{201}$ Capdetrey (2007) 202.

${ }^{202}$ Strabo 14.2.25.

${ }^{203}$ Capdetrey (2007) 105; Sherk (1992) 237.

${ }^{204}$ F.Amyzon 16.

${ }^{205} \mathrm{Ma}(1999) 175$.
} 
Thus, the poleis of Asia Minor continued to pursue an independent foreign policy (or the form of one), when they could, grasping for as much autonomia as they could get. Poleis reached across the borders of the kingdoms regularly and apparently without compunction in matters of religion, ceremony, and prestige such as invitations to new games and grants of asylia. These matters can easily be dismissed as minor matters, irrelevant beside the paucity of evidence for poleis entering into treaty negotiations or carrying out arbitrations independently of the kings, which do point to limits on the poleis' freedom in foreign affairs. However, this under-rates the significance of matters of religion, ceremony, and prestige in ancient diplomacy. ${ }^{206}$ It remains significant that poleis received and sent embassies on their own and competed for prestige on their own behalf on the international stage.

\section{Independence in Military Matters}

While, as discussed above, many of the cities in Asia Minor received royal garrisons both at the time of Antiochos III's reconquest and on earlier occasions, in many cases these garrisons were transient. ${ }^{207}$ It seems that the Seleukids preferred to garrison strategic points in the countryside and only a few key poleis, such as Lysimacheia, Ephesos and Sardis. ${ }^{208}$ The ungarrisoned poleis were not left defenceless either. Most of the cities had walls, most of which were built during one of two periods of heightened negotiation between the kings and the poleis - the initial Wars of the Diadochoi (323-281) or Antiochos III's rule over Asia Minor (213-189). Carlsson, investigating the process concludes that, where the construction of these walls is attested, they mostly seem to have been motivated by the poleis not the kings. ${ }^{209}$ Maintenance of these walls also seems to have been carried out by the poleis in at least some cases. At Erythrai, for example, a very short inscription records that:

When Damalos was hieropoios, the overseers of the walls for dampproofing the wall were...

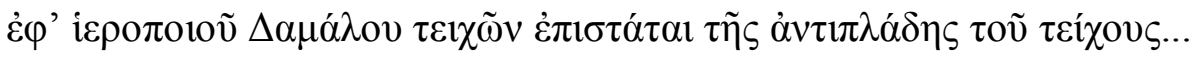

(I. Erythrae 23)

\footnotetext{
${ }^{206}$ Rigsby (1994) 24ff.

${ }^{207}$ Grainger (2002) 63.

${ }^{208}$ Bikerman (1938) 53; Ma (1999) 114f.; The Antigonids" "fetters of Greece" might offer a parallel.

${ }^{209}$ Carlsson (2010) 112-128; McNicoll (1997) 46.
} 
The fact that the eponymous official is mentioned means the overseers held an annual office, the hallmark of the civic official, ${ }^{210}$ and the context suggests a municipal liturgy. It is, perhaps, not surprising that the kings were content for the poleis to defray the expenses of their defences, but it might be expected that they would be less keen to see the poleis controlling those defense. Yet, at least in some cases, it is clear that the poleis did exactly this. In an inscription from Priēnē, for example:

Nymphōn, son of Prōtarchos who was formerly appointed phrourarchos of the citadel by the demos, maintained the guard attentively and correctly along with the guardsmen, and return[ed it] to the demos, just as he received it...

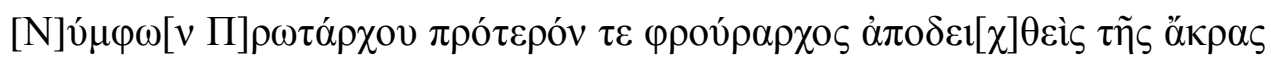

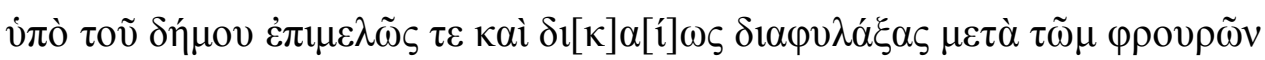

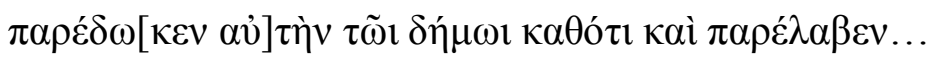

(I. Priene 22, l.2-7)

This inscription clearly indicates that Nymphōn was a civic official, required to maintain the city's garrison. The fact that he is said to have served alongside the guardsmen and to have returned the commission to the demos shows that "maintaining the garrison" meant commanding civic troops, not paying for a royal garrison. Part of the reason that Priēnē was allowed such control of its defences might be that it was a very minor settlement; ${ }^{211}$ if Priēnē acted up, the royal army could easily reduce it to submission (or to rubble). Therefore, allowing Priēnē to defend itself was the most economical option for the king. From the Seleukid king's perspective, though, this would be true of most poleis in Asia Minor, so it may be that the amount of control which Priēnē had over its defences was normal. It may also be that, while defences were maintained, they were not very good. In most poleis pre-existing walls were maintained, but were not modified to take account of third century developments in siege warfare, ${ }^{212}$ suggesting either that the cities could not afford to upgrade their walls or that the walls were more important for ideological reasons than military ones. Symbolically, walls could demonstrate a polis' ability to carry out a substantial public works project and to protect itself. By most definitions, a polis which was able to defend itself had autonomia and eleutheria and one that could not did

\footnotetext{
${ }^{210}$ McNicoll (1997) 64.

${ }^{211}$ Wycherley, (1951) 184.

212 McNicoll (1997) 74.
} 
not. ${ }^{213}$ Herodotos 1.164 offers an example of this attitude; in that passage, the Persians demand the demolition of a small section of Phōkaia's city wall as a symbol of submission and the Phōkaians refuse, abandon their whole city, and sail west, because

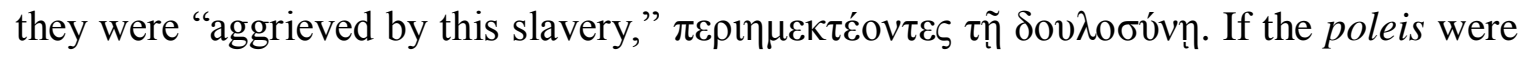
building and maintaining their own fortifications, then the kings were allowing the poleis a significant aspect of independence.

In addition to defences, the cities also retained their own offensive forces which engaged in attacks on rival poleis. ${ }^{214}$ Such forces were an important aspect of a free polis. ${ }^{215}$ One example of such forces in Asia Minor can be seen in Polybios 5.72-3, which recounts the siege of the Pisidian polis of Pednēlissos by Selgē, a neighbouring polis, during the period in which the Seleukid governor, Achaios, was ruling as king in Anatolia. The Selgians, "having sent out a general with a force" $\sigma \tau \rho \alpha \tau \eta \gamma o ̀ v ~ \varepsilon ̇ \xi \alpha \pi o \sigma \tau \varepsilon i ́ \lambda \alpha v \tau \varepsilon \varsigma \mu \varepsilon \varepsilon \tau \grave{\alpha}$ $\delta v v \alpha ́ \mu \varepsilon \omega \varsigma$ (Polyb. 5.73.1), attacked the army of Achaios, who was only able to defeat the

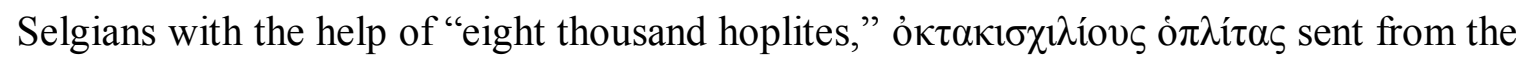
polis of Etenna, and four thousand from the polis of Aspendos (Polyb. 5.73.3-4). The poleis must have had a significant ongoing military organisation in order to train and equip such a substantial number of hoplites - clearly quite capable hoplites given Achaios' helplessness against the Selgian contingent and reliance on the Etennan reinforcements. These civic forces are not attested once Antiochos III had re-established control over Asia Minor, but they clearly were not abolished, because they reappear immediately after the Battle of Magnēsia and the withdrawal of the Seleukids from Asia Minor. Livy reports that, in 189, as Gnaeus Manlius Vulso marched through Pisidia on his way to Galatia, settling matters:

He reached the three fortresses of Taba ... as the forces of this region remained whole, it had men bruising for a fight. And then, an attack was made on the Roman column, [their] horsemen created confusion by their first, extraordinary assault.

ad Tabas tertiis castris perventum... integris viribus regionis eius feroces ad bellandum habebat viros. tum quoque equites in agmen Romanum eruptione facta haud modice primo impetu turbavere

(Livy 38.13.11-12).

\footnotetext{
${ }^{213}$ Ibid., 71; Wycherley (1962) 37f.

${ }^{214} \mathrm{Ma}(2000 \mathrm{a}) 343 \mathrm{ff}$.

${ }^{215}$ Hansen (2006) 116.
} 
It is difficult to believe that these horsemen were a newly formed regiment - they were competent and organised enough to (temporarily) throw the Roman army into disorder. ${ }^{216}$ It seems far more likely that these forces, and presumably the militias elsewhere, had been in existence throughout the period of Seleukid rule. ${ }^{217}$ Military roles were of central importance in Greek understandings of eleutheria, and the possession of an army - the ability to use force to defend against attack, avenge insults, and assert the city's will was basically the definition of civic freedom for the Greeks. ${ }^{218}$ Antiochos III's lightning conquest of the Thracian Chersonese, to almost no opposition, ${ }^{219}$ shows that civic forces could not oppose the full force of the Seleukid royal army, ${ }^{220}$ so poleis with their own military forces were not really capable of asserting their will against the king by force. Nevertheless the possession of walls and forces of their own gave the poleis some means of defending themselves and compelling others - a central aspect of eleutheria in theory and (potentially) in fact.

\section{Conclusion}

The ideological requirements of the kings and poleis thus shaped the relationship between them: the kings demanded recognition of their supreme status from the poleis, while the poleis desired freedom. These demands, though apparently antithetical, could be reconciled; the kings were flexible about how the poleis acknowledged their supremacy and the poleis were willing to settle for narrow definitions of freedom. The poleis initially modelled this relationship on their interactions with the gods, but increasingly developed a unique system. The kings were presented as benefactors and allies - superior partners rather than overlords. Polis loyalty was made conditional on continued royal efficacy and was based on honouring their debts to the kings, rather than on unconditional submission. The kings were complicit in this presentation of their relationship. Not only did Hellenistic kingship encourage kings to adopt multiple roles, but there were also personal reasons: it was flattering to be honoured as a god. Perhaps the idea that the poleis obeyed freely and willingly was even more flattering to the kings, whose every wish was a command.

\footnotetext{
${ }^{216}$ Xen. Eq. Mag. describes the intensive training that cavalry forces required to be effective.

${ }^{217} \mathrm{Ma}$ (2000a) 343ff.

${ }^{218}$ Austin \& Vidal-Naquet (1977) 126.

${ }^{219}$ Livy 33.38.9.

${ }^{220}$ Grainger (2002) 69.
} 
This presentation of the relationship coincided with reality to a certain degree, but not entirely. The poleis would not have been subject to the kings at all if not for the kings' overwhelming military power - they were fairly quick to switch their allegiances when it seemed more politick and those few poleis, like Smyrna, which considered themselves strong enough to pursue complete independence, did so regardless of their debts to the Seleukid dynasty. On the other hand, the kings theoretically could have retained the façade of a friendly relationship while actually demanding complete submission, as they did with their officials whom they referred to as their friends ( $\varphi$ í $\lambda \circ \mathrm{r}$ ) even as they gave them orders. ${ }^{221}$ But the kings actually did allow the poleis significant autonomy, even in such important spheres as foreign affairs and military matters. The reasons for this lie in the nature of Seleukid control of Western Asia Minor: intermittent, threatened by Ptolemaic and Gallic raids, and challenged by sheer distance. These factors, unique to Asia Minor, all encouraged the Seleukids to take a conciliatory approach to the poleis in fact as well as word.

${ }^{221}$ Herman (1982) 103. 


\section{CHAPTER TWO: THE SELEUKID HEARTLAND AND REASONS FOR COLONISATION}

In Western Asia Minor it is clear that poleis enjoyed substantial freedom in their internal and even external affairs. Except in extraordinary circumstances such as military campaigns, the kings took pains to treat these cities as if they were allies, not subjects. The poleis of Asia Minor were sometimes able to leverage that simulacrum of freedom into freedom in fact. But Western Asia Minor was in many ways aberrant and, while important to the empire, was only a province, not the heartland - that was Syria and Mesopotamia. Many of the factors which encouraged the Seleukids to take a hands-off approach in Western Asia Minor did not apply to Syria and Mesopotamia: distance was not a factor, royal control of (most of) the region was constant, and the region was far more important to the continued existence of the kingdom as a whole. The cities in this region, founded by Seleukos I and settled by Macedonian veterans and Greek migrants, did not have the same desire for independence as those of Asia Minor. They had no long history of autonomy and their communal identities were closely tied to their position within the Seleukid Empire. Nevertheless, the new foundations were indeed poleis, and from their foundation they were essential to the kings' control of the region. The sparse epigraphic, literary, and numismatic evidence suggests that the Greek cities in Syria and Mesopotamia, like those in Asia Minor, engaged in status negotiation with the Seleukid kings and achieved a degree of autonomy - but a significantly narrower degree than the cities in Asia Minor enjoyed. The poleis possessed their own civic institutions, but their internal affairs were subject to intensive, undisguised royal interference. In the final period of the Seleukid empire after the loss of Mesopotamia in 140 BC, the kings became increasingly reliant on the poleis, which gained more autonomy as a result but never sought to leave Seleukid rule altogether, even as the dynasty self-destructed around them.

\section{Overview of the Heartland}

There was no single capital of the Seleukid kingdom in the modern sense, ${ }^{222}$ nor even in the sense that the Ptolemies had Alexandria or the Attalids had Pergamōn. Polybios and Diodoros' accounts usually present Antiochos IV as residing at Antioch, ${ }^{223}$ because that is where visitors from the Western Mediterranean usually found him, but in fact the

\footnotetext{
${ }^{222}$ That degree of institutionalisation did not yet exist: Billows (1990) 242; Sherwin-White (1987) 16.

${ }^{223}$ Polyb. 26.1ff \& 30.25ff; Diod. Sic. 31.16ff
} 
Seleukid court was peripatetic. ${ }^{224}$ Antiochos III and Antiochos IV spent large portions of their reigns on campaign, and even in peacetime they tended to travel widely; the Babylonian astronomical diaries record the king residing in Seleukeia-on-the-Tigris and Antioch, ${ }^{225}$ and making ceremonial visits to Babylon. ${ }^{226}$ Tours elsewhere are mentioned in II Maccabees. ${ }^{227}$ Thus, rather than being based on a core city, the Seleukid kingdom was based on a core region. The prevailing view used to be that this core was Syria alone. ${ }^{228}$ But, it has become increasingly clear that, before the loss of Mesopotamia in 140, there was a dumbbell-shaped heartland with two central nodes, Syria and Mesopotamia, which were separate but very strongly linked (see Figure two for a map of Syria and Figure three for a map of Mesopotamia and the Near East). ${ }^{229}$

Both nodes were centred on new cities, founded by the kings in comparatively under-developed regions and settled by Greco-Macedonian elites; both nodes had a roughly comparable total population; and both nodes were surrounded by centres of the native populations, which continued to thrive. However, the two nodes of the dumbbell differed in a few important ways. Functions were more disparate in Syria, though Antioch clearly dominated; there were multiple mints and mint-standards in Syria, for example, as opposed to the single mint in Mesopotamia. The most important distinction, however, was the orientation of each node in relation to the wider world - people of the Syrian cities are well-attested in inscriptions from further west and later Greek and Roman sources tend to think of it as the core of the kingdom. By contrast, the Mesopotamian node looked east - Mesopotamian Greeks are very rarely attested in the west, and eastern sources, such as the Babylonian astronomical diaries, considered this region the core of the kingdom, calling Seleukeia-on-the-Tigris "the royal city" (URU LUGAL-tú / āl $\check{s} a r r \bar{u} t i)^{230}$ and very rarely mention Syria. Janus-like, the two nodes faced in opposite directions - a major strength of the empire. Significantly, while the Seleukids survived the loss of Asia Minor to the Romans without serious issue, they collapsed into utter chaos almost immediately after the loss of Mesopotamia. The system was based on the connection that bound the two cores together - the route passing along the Euphrates,

\footnotetext{
${ }^{224}$ Kuhrt (1996): 45; Ma (1999) 7.

${ }^{225} A D$-181 Rev. 8-9; -155 Upper edge 1-2

${ }^{226}$ AD -204 C Rev. 14-18.

227 II Macc. $4.18 \& 4.43$

${ }^{228}$ E.g. Bevan (1902) 1. 208-209; Seyrig (1970) esp. 301ff.; Welles (1966) 283. Cohen remains of this opinion: (2006) 81, as does Ma, to the extent that he allows the empire to have a heartland at all, (1999) 7.

${ }^{229}$ Billows (1995) xv; Ehrenberg (1969) 145; Invernizzi (1993) 234; Sherwin-White (1987) 17.

${ }^{230}$ e.g. AD, -273 B rev 31.
} 
through cities like Seleukeia Zeugma, Doura-Eurōpos, and Jebel Khalid. ${ }^{231}$ Bronze coins were not usually accepted far from their mint of origin, but at Doura-Eurōpos the majority of the bronzes were from Antioch - proof of the deep commercial links along the route. ${ }^{232}$ The route itself survived the division of the Seleukid kingdom between Rome and Parthia; Isidōros of Charax recorded it in detail in his itineraries around the time of Augustus. ${ }^{233}$

\section{The Tetrapolis of Syria}

The western end of the dumbbell, Syria, was composed of a system of cities centred on four major cities, known as the Tetrapolis, which consisted of two port cities: Seleukeiain-Pieria and Laodikeia-by-the-Sea, and two inland ones: Antioch by Daphnē and Apameia. ${ }^{234}$ All four cities were founded by Seleukos I in $300,{ }^{235}$ all, apparently, on a common plan - excavations show that the insulae at Antioch and at Laodikeia were of nearly identical dimensions. ${ }^{236}$ Seleukeia-in-Pieria and Antioch were clearly intended to be a pair - they are only half a day's travel from each other on foot, and the river Orontēs is navigable between them. Laodikeia and Apameia are sometimes taken as a second pair, but the Bargylos mountain range (the modern an-Nuṣayriyah / al-'Alawīyin) would have made communication between them difficult - they are better seen as a south-western and south-eastern extension of the northern pair, guarding the approaches from Ptolemaic Koile-Syria. Three further cities attached the Tetrapolis to the wider world: Kyrrhos to Kommagēnē and Armenia in the northeast, Arados to Phoenicia in the south, and Beroia (Aleppo) to Mesopotamia and the east. ${ }^{237}$

From Strabo 16.2.4-10, it is clear that the cities were carefully planned, with specific functions. The two coastal cities served as ports, while the two inland cities enabled communication with Mesopotamia. ${ }^{238}$ The northern pair, Seleukeia and Antioch, had administrative functions and each has been referred to, anachronistically, as Seleukos'

\footnotetext{
${ }^{231}$ Nixon (2002) 291; Seyrig (1970) 292.

${ }^{232}$ Bellinger (1949) 196.

${ }^{233}$ Isidōros of Charax, Parthian Stations 1.

${ }^{234}$ Strabo, 16.2.4 (on the Tetrapolis); 16.2.5-6 (on Antioch); 16.2.9 (on Laodikeia); 16.2.10 (on Apameia).

${ }^{235}$ Malalas 8.199 provides exact dates.

${ }^{236}$ The city blocks in Antioch and Laodikeia were of almost exactly the same size (Antioch: 112 x 58 metres and Laodikeia 112 x 57 metres): Downey (1961) 70. Due to modern cities on the sites of Antioch and Laodikeia and the complete reconstruction of all the cities after earthquakes in Roman and Late Antique times, excavations tell us practically nothing else about the state of the Tetrapolis in the Hellenistic Period.

${ }^{237}$ Seyrig (1970) 299.

${ }^{238}$ McNicoll (1997) 83 ; Rostovtzeff (1941) 478.
} 
intended capital. ${ }^{239}$ Laodikeia and Apameia, closer to the border with Ptolemaic KoilēSyria, had a pronounced military character; much of the fleet was berthed at Laodikeia, ${ }^{240}$ while Apameia and its satellite towns were the home barracks for much of the army and stabled the empire's elephants. ${ }^{241}$ Strabo reports that there was line-of-sight from the Bargylos Mountains to both Laodikeia and Apameia, ${ }^{242}$ and that this was known suggests the presence of watchtowers in the mountains. Laodikeia also had pronounced commercial functions, ${ }^{243}$ and minted a special coinage for Mediterranean trade. ${ }^{244}$

We have little indication of the population of these cities. By the time of the Roman Empire, Antioch was very large. Strabo puts Antioch in the top tier of settlements:

... not much behind Seleukeia-on-the-Tigris and Alexandria-by-Egypt in power and size.

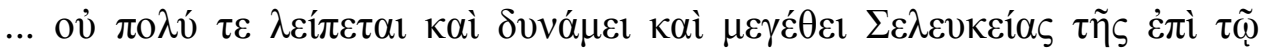

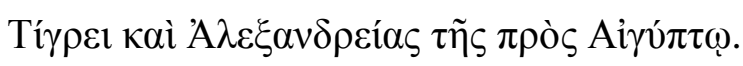

$(\text { Strabo 16.2.5) })^{245}$

This scale dates back at least as far as the reign of Antiochos IV (175-163), who doubled the size of the city when he added the new quarter, Epiphaneia. ${ }^{246}$ I Maccabees and Diodoros record (separate) massacres of Antiochenes under the later Seleukids, numbering in the hundreds of thousands ${ }^{247}$ - not accurate figures, obviously, but indicative of the authors' impressions of Antioch in their time as a very large city. On the other hand, the other cities of the Tetrapolis seem to have been quite small. Polybios reports that, when Antiochos III recaptured Seleukeia-in-Pieria after several decades as a Ptolemaic exclave:

\footnotetext{
${ }^{239}$ Grainger (1990a) 60; Seyrig (1970) 302.

${ }^{240}$ Cic. Phil. 9.4.

${ }^{241}$ Strabo 16.2.10.

242 Ibid., 16.2.9.

243 Ibid.

${ }^{244}$ Houghton (1999) 180.

${ }^{245}$ Diod. Sic. 17.52 claims that civic officials told him that the registers of Alexandria in his time recorded 300,000 free people, which Downey takes as an indication of the sort of scale that Strabo had in mind: (1958) 86. For logistical reasons, I doubt that Alexandrian officials would have been able to produce such a total with any degree of accuracy. Even if this number did accurately reflect the contents of the registers, it would be significantly larger than the free population residing in the city, for Alexandria's registers included most of the substantial number of Macedonians settled on kleruchies throughout the Egyptian countryside: McEvedy (2011) 5-6.

${ }^{246}$ Malalas, 8.205.

${ }^{247}$ I Macc. 11.45 \& Diod. Sic. 34/35.17.
} 
The king ... agreed to give safety to those who were free: these were around six thousand. After he took the city, he not only spared those who were free, but also brought back those who had fled from Seleukeia, and restored both their citizenship and their property.

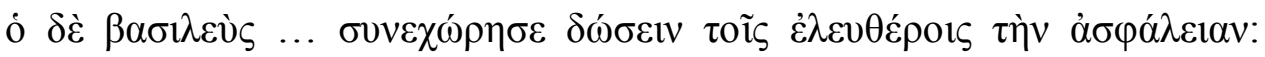

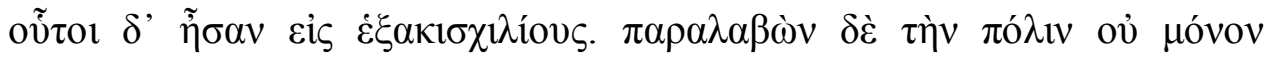

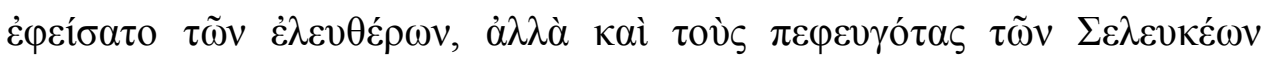

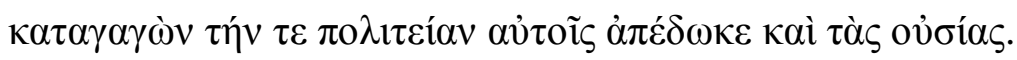

(Polyb. 5.61.1-2)

The natural meaning of $\dot{\varepsilon} \lambda \varepsilon v \theta \dot{\varepsilon}$ pors would be the free male population of the city, which would make Seleukeia relatively small. Perhaps the city had become heavily depopulated under Ptolemaic rule - Polybios' six thousand cannot include the exiles whom Antiochos resettled in the settlement, because they would not have needed a guarantee that they would be protected during the sack of a city which they were not in. The number of initial settlers at Antioch given by Malalas would seem to fit with the small number of free men Polybios reports at Seleukeia:

After the destruction of Antigonia, ${ }^{248}$ Seleukos made the Athenians living in Antigonia resettle to the polis of Antioch the Great, which he had built... as well as some Macedonian men: in total 5,300 men.

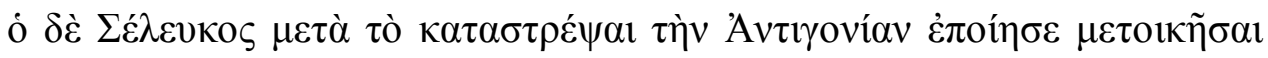

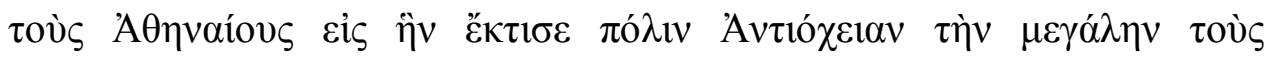

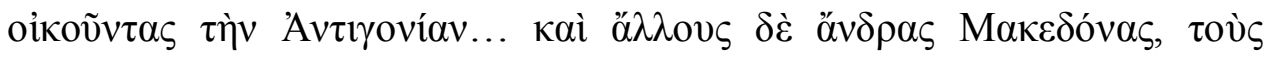

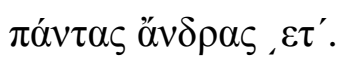

(Malalas 8.201)

So, the free population of Seleukeia, given a small amount of population growth and the absence of exiles, could be the descendants of a similar number of Greek and Macedonian colonists - assuming Malalas' figures are accurate. On the one hand, Malalas is late, muddled, and in his manuscripts the numbers are frequently corrupt. ${ }^{249}$ On the other hand, numbers are not necessarily as prone to corruption as is generally

\footnotetext{
${ }^{248}$ Antigonos I Monophthalamos' Syrian capital, upstream of Antioch. Exact location unknown.

${ }^{249}$ Jeffreys (1986) xxii.; Treadgold (2007) $721 f$.
} 
assumed, ${ }^{250}$ and the apparatus critici show no disagreement between the manuscripts on this particular figure. ${ }^{251}$ There are good reasons why Malalas might have had access to the correct figure: Antioch was Malalas' hometown and he or his sources used a local history which drew on an official record of the cities' foundation ${ }^{252}$ and also supplies such information as the exact date on which each of the poleis were founded. ${ }^{253}$

It is probable that each of the foundations received a similar number of settlers, which seems likely given that the four cities were otherwise built on the same plan and had similar initial intramural areas. ${ }^{254}$ This could be supported by the agreement between Malalas' figure and that of Polybios 5.61. In that case, at their foundations the total free male population of Tetrapolis would have been a little over twenty thousand and the total population could have been over a hundred thousand people, if Polybios and Malalas' figures exclude women, children, and slaves. ${ }^{255}$ This is a very large number of people to have been added to a region suddenly. Of the Tetrapolis, Antioch, at least, grew consistently, receiving new quarters under Seleukos II and Antiochos IV (the aforementioned Epiphaneia), as well as one built by "the mass of colonists,"

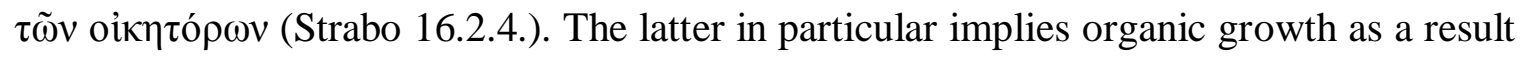
of urban migration. The other poleis show less signs of growth and the correlation between Malalas' foundation figure and Polybios' late third century BC one suggests that at Seleukeia, at least, population remained stable, rather than shrinking. That the new foundations maintained their populations and, further, that Antioch was able to grow indicates that Syria had proven capable of feeding the initial influx of settlers, with enough surplus for new migrants to survive also.

It is usually assumed that large non-free Syriac and Jewish populations lived in the poleis alongside the citizens of Greco-Macedonian descent. However, it is unclear how large these Syriac and Jewish populations were, and it seems likely that they formed

\footnotetext{
${ }^{250}$ Even the alphabetic numerals which Malalas uses: Develin (1990) 42. Many of the unreliable numbers in Malalas seem to arise from copyists trying to fix his chronology, which is not internally consistent. This pressure would not apply to the population figure under discussion here.

${ }^{251}$ Jeffreys (1986) 106; Thurn (2000) 152, n. 94.

252 Treadgold (2007) 737.

${ }^{253}$ Seleukeia on the $23^{\text {rd }}$ Xanthikos: Malalas 8.199, and Antioch on the $22^{\text {nd }}$ Artemisios: Malalas 8.200. Malalas does not offer exact dates often and never for events outside of the Tetrapolis. Note also that the order of the dates preserves the fact that Seleukeia was founded first, which a later invention would not be inclined to do.

${ }^{254}$ Cf. Antioch in McEvedy (2011) 20 and Laodikeia-by-the-Sea in Owens (1991) 82.

${ }^{255}$ Downey uses Malalas' figure to estimate 17,000-25,000 as the total population of Antioch at foundation: (1958) 85 .
} 
as the result of a slow process of urban migration rather than being settled in the poleis when they were founded. They could not have been pulled from native cities, for Syria under the Achaimenids seems to have been overwhelmingly rural. ${ }^{256}$ There is little question that Damascus in Koile Syria was a city under the Achaimenids, ${ }^{257}$ and almost everyone assumes some habitation at Aleppo, though the archaeological evidence for urbanisation is meagre. ${ }^{258}$ Otherwise, neither archaeology, nor contemporary Greek sources (principally Xenophon's Anabasis) provide evidence for large-scale settlements in Achaimenid Syria. ${ }^{259}$ Unlike anywhere else east of the Tauros Mountains, the smallerorder settlements received Greco-Macedonian names, implying that they were settled for the first time as Greek foundations, rather than being pre-existing Syriac towns. ${ }^{260}$ At Doura-Eurōpos, also a foundation of Seleukos I (indirectly), the first generations of settlers almost all had Macedonian names. ${ }^{261}$ The initial influx of Greco-Macedonian settlers into Syria would have been a heavy burden on Syria's carrying capacity without also decreasing the region's crop yields by pulling people off the land. The Syriac sanctuary sites of Baalbek and Bambykē already existed at the beginning of Seleukid rule, ${ }^{262}$ and it is probable that they formed central markets and administrative meeting places for an entirely rural Syriac population - just as the Temple in Jerusalem did in Achaimenid Judaea. ${ }^{263}$ Indeed, this is the role envisaged for the sanctuary of Baitokaike in a letter from an uncertain Antiochos which is inscribed there. ${ }^{264}$ From Seleukos I onwards, the Seleukids poured money into these sanctuaries, ${ }^{265}$ implying that the Seleukids wished for the sanctuaries to continue to perform their administrative role in a traditional manner, not to disrupt things by uprooting masses of Syriacs and moving them into the new poleis. Syriacs did move into the cities of the Tetrapolis over time (as did the

\footnotetext{
${ }^{256}$ Millar draws attention to the complete lack of data on the period: (1998) 111ff.. Several scholars take it as given that the area had not been urbanised hitherto: Grainger (1990a) 7: "exclusively rural" and "almost a blank when Alexander's army invaded," 28; Musti (1966) 185: "Esse [città nuove] sorgevano in quell'angolo settentrionale della Siria per cui non si conosce un notevole sviluppo cittadino, per l'età anterior alla conquista macedone..." (These [new cities] arose in the northern quarter of Syria, in which one does not perceive significant urban expansion during the period before the Macedonian conquest...)

${ }^{257}$ Arr. Anab. 2.11.9-10.

258 e.g. Shipley (2000) 303; Cohen (1978) 17; vs. Millar (1998) 112.

${ }^{259}$ Millar (1998) 116.

${ }^{260}$ Sherwin-White \& Kuhrt (1993) 114.

${ }^{261}$ Rostovtzeff (1941) 487.

262 Ragette (1980) 27-28; Bambykē had been issuing coinage for some time: Houghton \& Lorber (2002)1.1.27.

${ }^{263}$ Schaper (1995) 528-539; Sherwin-White \& Kuhrt (1993) 60. They did not become urban centres until the Late Seleukid or Early Roman period.

${ }^{264}$ IGLS 7.4028 l.26.

${ }^{265}$ Lucian, Syr. D. 19-21.
} 
Jews), but they did so gradually, as part of a process of urban migration. As such, they might have been more inclined to Hellenise than if they had arrived as a single large group. In this regard, it is notable that none of the cities of the Tetrapolis featured Syriac deities on their coinage at any stage, while the coins of Damascus, which definitely had a continuous existence as a Syriac city, and of the Syriac-dominated sanctuary sites did. ${ }^{266}$

Thus, it seems probable that at their foundation the cities of the Tetrapolis had a largely Greco-Macedonian demographic character. ${ }^{267}$ The initial influx of GrecoMacedonian settlers may have been fairly large and, at Antioch in particular, the population grew throughout the Hellenistic, with the migrants whether Greek, Jewish, or Syriac probably being largely assimilated into the dominant culture.

\section{Mesopotamia}

The Seleukid presence in Mesopotamia dates back even further than in Syria - Seleukos I had served at Babylon under Perdikkas and was appointed Satrap of Babylon at Triparadeisos in 322. ${ }^{268}$ The Seleukid calendar era counted the years from Seleukos' dramatic reconquest of the city from Antigonos in 311, indicating Mesopotamia's central importance to the Seleukid dynasty. In contrast to the Syrian Tetrapolis, Seleukos' colonising efforts in Mesopotamia were focused on the single city of Seleukeia-on-theTigris, founded on the site of Oppis. ${ }^{269}$ Some of the other cities in the region received some Greco-Macedonian settlers, as in the case of the old Persian capital, Susa (which was renamed Seleukeia-on-the-Eulaios), but many other pre-existing cities did not, including the important administrative and cultural centre of Uruk. ${ }^{270}$ Though the Seleukid colonising efforts in Mesopotamia were focused primarily on one foundation, it was a massive one. Archaeological surveys of the site show that, at its foundation, Seleukeia-on-the-Tigris covered 550 hectares and had exceptionally large insulae of 75x150 metres - Antioch-by-Daphnē at its foundation occupied only 75 hectares, with insulae of 58x120 metres. ${ }^{271}$ As mentioned above, Strabo cited Seleukeia-on-the Tigris as

\footnotetext{
${ }^{266}$ Wright (2009/10) 198-199.

${ }^{267}$ Rostovtzeff (1941) 1.487.

${ }^{268}$ Diod. Sic. 18.39.6; Phot. Bibl. 92.

${ }^{269}$ At the eastern end of the Royal canal which linked the Euphrates and Tigris and famous for the mutiny against Alexander which took place there in $324 \mathrm{BC}$.

${ }^{270}$ Uruk seems to have gradually absorbed some of the institutions of polis life, however: McEwan (1988) 413f.

${ }^{271}$ Seleukeia: Invernizzi (1993) 235; Antioch: Downey (1961) 20 \& McEvedy (2011) 20.
} 
an example of the largest order of city in the East, on par with Alexandria-by-Egypt. ${ }^{272}$ Pliny the Elder claims that in his time it was thought to have a population of six hundred thousand, ${ }^{273}$ which is improbable, ${ }^{274}$ but would reflect a general impression among its contemporaries that Seleukeia was a very large city indeed. In the time of Strabo and Pliny the city was primarily significant because of its connection with the Parthian winter capital, Ktēsiphōn, across the river, but Strabo saw the city as having had a major role within Seleukos' empire too, saying that:

... [Seleukos] and all those after him zealously supported that city and transferred the royal palace there...

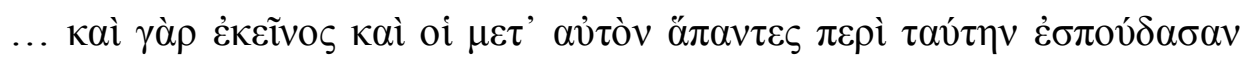

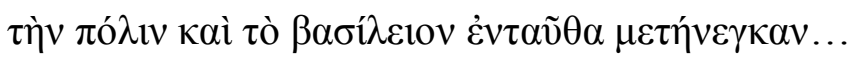

(Strabo 16.1.5)

$\beta \alpha \sigma i \hat{\imath} \varepsilon 10 v$, here, means the primary residence of the king and the administrative functions that went with that, particularly the treasury. ${ }^{275}$ This seems to imply that Strabo thought of Seleukeia-on-the-Tigris as the sole Seleukid capital. Since it was founded before the Syrian cities, for a time it may have been. It did not stay that way, for at 16.2.5 he mentions that there was also a basileion at Antioch, and the kings became highly peripatetic once their kingdom expanded beyond Babylonia. Since it was the capital of the satrapy of Babylonia, the Babylonians treated Seleukeia as the king's primary residence, consistently referring to it alone as "the royal city" (URU LUGAL-tú / āl $\check{s} a r r \bar{u} t i)$, a term for the king's main city which dated back to Neo-Assyrian times. ${ }^{276}$ This reflects the Babylonian diaries' highly parochial view of the world, rather than indicating that it was actually the Seleukids' sole capital. ${ }^{277}$ Nevertheless, the diaries and the archaeological evidence confirm the impression given by Strabo and Pliny of a

\footnotetext{
${ }^{272}$ Strabo, 16.2.5.

${ }^{273}$ Plin. NH. 6.122.

${ }^{274}$ Excavations to date suggest that Seleukeia continued to cover roughly 550 hectares, or $5.5 \mathrm{~km}^{2}$, a relatively large area for an ancient city. However, 600,000 inhabitants would give a population density of 109,000 people $/ \mathrm{km}^{2}$ - over six times the density of modern Hong Kong Island! $\left(16,230\right.$ people $/ \mathrm{km}^{2}$ : Hong Kong Census \& Statistics Dept. Population \& Vital Events, www.censtatd.gov.hk/FileManager/EN/ Content_803/population.pdf, accessed $27^{\text {th }}$ Oct. 2012). If there is any truth to Pliny's figure, perhaps it applies to the whole Parthian settlement complex, including Ktēsiphōn, Vologesocerta, and large (archaeologically unattested) outer suburbs.

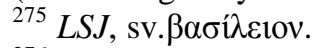

${ }^{276}$ Ikida (1979) $76 f$.

${ }^{277}$ Kuhrt (1996) 44; Sherwin-White (1983) 270. The extant diaries mention Antioch only twice: -155 A Upper edge 1-2 \& -149 A Rev. 3-13; less often than they report the presence of escaped dogs on the streets of Babylon.
} 
persistently enormous settlement - in the ancient world, such large-scale settlements could only be maintained by the on-going patronage of the central government. ${ }^{278}$

Mesopotamia, unlike Syria, was heavily urbanised and Seleukeia-on-the-Tigris was, from the first, settled in part by inhabitants from Babylon. A strong tradition, represented by Pliny, Pausanias, and Strabo, holds that Seleukos transferred the entire population of the city except for the priests to Seleukeia-on-the-Tigris. ${ }^{279}$ However, cuneiform records and archaeology show that, if Babylon declined during the Seleukid period, it did so gradually, ${ }^{280}$ and the extensive royal patronage of Babylon seems incongruent with a policy of depopulation. ${ }^{281}$ Further, Josephos mentions that a large group of Jews were driven out of Babylon by the Babylonians in the first century AD, which implies that the city remained populated well into Parthian times. ${ }^{282}$ Given that Babylon was not the only native city in Babylonia, it seems implausible that the new foundation would have drained Babylon exclusively. The story that Babylon had been depopulated by Seleukeia probably reflects the telescoping of a gradual process of population shift, ${ }^{283}$ first-century AD concerns among the Seleukeians about the Parthian patronage of the cities of Ktēsiphōn and Vologesocerta, ${ }^{284}$ and the power of the image as a symbol for the Hellenisation of the East.

While Babylon was not depopulated, it is nevertheless certain that Mesopotamians were resettled at Seleukeia (in addition to those who already lived at Ōpis); the scale of the initial foundation makes clear that Seleukos intended that Seleukeia-on-the-Tigris be a massive city, and it seems highly unlikely that he was able to ship the bulk of its inhabitants all the way from Greece and Macedon. Seleukos probably founded the city while he was still at war with Antigonos, and thus could not afford to settle vast numbers of his soldiers in the foundation. ${ }^{285}$ At that time, Antigonos still controlled Syria and the

\footnotetext{
${ }^{278}$ Van Dam (2010) 6-10.

${ }^{279}$ Plin. NH. 6.122; Paus. 1.16.3; Strabo 16.1.5.

${ }^{280}$ Boiy (2004) 136 \& 142; van der Spek (1993) 98;

${ }^{281}$ Kuhrt \& Sherwin-White (1991) 82; Sarkisian (1969) 319; Sherwin-White (1987) 18.

282 Joseph. AJ 18.373.

${ }^{283}$ McEwan (1988) 413.

${ }^{284}$ Plin. NH. 6.122 asserts that the Parthians only founded these cities (which were satellite settlements of Seleukeia) "to empty out [Seleucia] in turn" invicem ad hanc exhauriendam. There is no archaeological evidence for this and the population of the region grew throughout the period, so there the foundation of these cities need not have been at the demographic expense of Seleukeia. They did, however, take its political predominance.

${ }^{285}$ The foundation date of Seleukeia is uncertain. Invernezzi (1993) 235 dates it to before $306 / 5$ BC on numismatic grounds (ESM 1-8 = SC 115.2, 117.1, 125.1, 125.2, 126), but these coins have been redated to c.300 and after by Houghton \& Lorber (2002) 52ff.. Strabo 16.1.5, discussed above, says the Seleukos
} 
Levant, blocking Seleukos' access to the Mediterranean, so Seleukos could not import Greeks from the west either. ${ }^{286}$ The large Mesopotamian population is reflected by the enormous cuneiform archive in the city's agora - the largest archive from the Hellenistic period. ${ }^{287}$ Thus, unlike the Syrian cities, the bulk of the population of Seleukeia-on-theTigris was non-Greek from the start, and in choosing to found a city when he did, where he did, on the scale he did, Seleukos must have known and intended that it would be so.

Throughout the east, the natives must have far outnumbered GrecoMacedonians, ${ }^{288}$ whose numbers were very limited - Billows calculates that only twentyfive thousand Macedonian men were available to be settled in the new Hellenistic kingdoms. ${ }^{289}$ When the natives stayed in the countryside or in traditional cities, their taxes were redirected to profit the new Greek centres rather than the old Persian ones, but things otherwise remained much the same. ${ }^{290}$ When natives moved to the new Seleukid foundations (as at Seleukeia-on-the-Tigris) they were allowed to incorporate a politeuma (association) of their own under the aegis of the polis, giving them some civic rights and also a discrete identity. ${ }^{291}$ Relations between the Greek elite, who were full citizens, and these politeumata were often less than cordial; Josephos describes relations between Greeks and the Mesopotamians in Seleukeia-on-the-Tigris in the first century AD:

The norm much of the time is for there to be stasis and discord between the Seleukeian Greeks and the Syrians, ${ }^{292}$ and the Greeks dominate.

\footnotetext{
transferred the royal palace to Seleukeia, weakly implying that he was already king (i.e. after 306 BC) when he founded the city, and his assumption of the diadem would have been a natural time for Seleukos to found a city named after himself: Hopkins (1972) 5. Hadley (1978) 230, argues that the war with Antigonos makes a foundation before $300 \mathrm{BC}$ improbable, but Seleukos founded the Tetrapolis, including its coastal cities, when war loomed with Ptolemaios and was still ongoing with the sea-king Dēmētrios Poliorketēs. Grainger (1990b) 100, argues that the city was most easily founded after Antigonos' attack on Babylon (309 BC), when there would have been large numbers of refugees in need of settling. The only surviving Babylonian astronomical diaries for the period discuss, of all things, astronomy, and offer no assistance in resolving this issue.

286 Aperghis (2004) 94.

287 Centro Richerche Archeologiche e Scavi di Torino, "Seleucia on the Tigris: The Archives" http://www.centroscavitorino.it/en/progetti/iraq/seleucia-archivi.html. (Accessed 25/9/2012).

${ }_{288}$ Aperghis (2004) 94; Ehrenberg (1969) 153; Jones (1940) 161.

${ }^{289}$ Billows (1995) 154ff. But estimates vary widely, e.g. Jones (1940) 23-25 calculated that there were only fifteen thousand Macedonians available for colonisation, that each city must have had at least five thousand (Presumably on account of Malalas 8.201), that not many Greeks can have been settled because the sources are always emphasising the settlement of Macedonians, and that the Macedonians must therefore have been the majority of the colonists (which does not necessarily follow). He thus concludes that the kings cannot actually have founded very many cities at all.

${ }^{290}$ Eddy (1961) 110.

${ }^{291}$ Cohen (1978) 86.

292 Josephus calls the Mesopotamians "Syrians" because they were Aramaic speakers (i.e. Syriacs).
} 


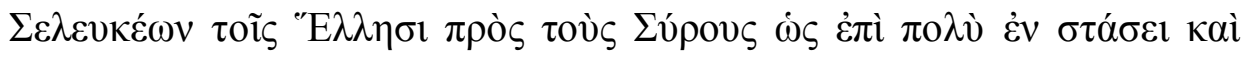

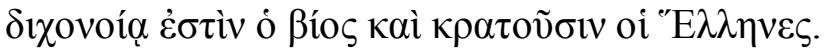

(Joseph. AJ 18.374)

The passage suggests that, by that time, Greek dominance was fragile, because the arrival of the aforementioned group of Jews from Babylon supposedly upsets the bases of Greek control. Cohen argues that the Greeks "functioned as an exclusive group" to avoid being absorbed, ${ }^{293}$ but this exclusion was not total, for later in Josephos' narrative above, the Greeks go out individually to speak to "their acquaintances among the Syriacs" $\tau \tilde{\omega} v$

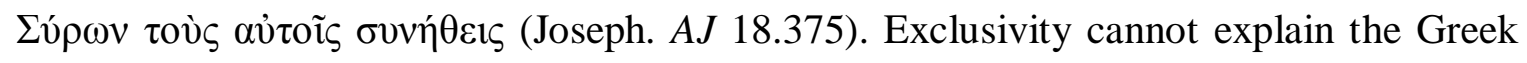
strength in the Seleukid period, either, since the passage shows that their power had weakened, but gives no reason to think that their expression of ethnic identity had changed. The Greeks' weakness by the time of Josephos is most naturally explained as a result of decreased support under Parthian rule - by then they were one ethnic group among many rather than the dominant culture of the empire. In that case, the Greeks' previous strength under the Seleukid rule indicates the importance of the military, ideological, and financial support which they received from the Seleukid king.

Thus, the new foundations of the Seleukid Empire fell into two major categories. In the west, there was the Tetrapolis of Syria, composed of four major settlements and several minor satellites, which were (initially) rather small and predominantly Greek, surrounded and supported by Syriac peasantry. In the east there was Seleukeia-on-theTigris, which was always massive, and, though ruled by a Greek elite, had a large Mesopotamian population. The two centres were linked by a chain of foundations along the Euphrates.

\section{Were the Foundations of the Heartland Poleis?}

All of the Seleukid foundations had Greek elites and a Greek flavour, but scholars differ substantially on whether they properly counted as poleis. Some early scholarship saw the Hellenistic foundations as full poleis, essentially mini-Athenses in the east, but an equally substantial current maintained that the polis, especially in the political sense, had become completely extinct after the Battle of Chairōneia in 338. More recent scholarship has tended to take a middle ground, emphasising continuity between the Classical and Hellenistic periods and the on-going vitality of the polis in the Hellenistic, while also

${ }^{293}$ Cohen (1978) 33; Jones (1940) 160. 
emphasising that most Classical poleis were not like Athens. These scholars interpret the new Hellenistic foundations, such as the cities of Syria and Mesopotamia, as being in much the same mould as less exceptional Classical poleis. However, the alternate view that either the polis was entirely extinct or, at least, that the new foundations were not poleis persists, and there is really no agreement in the literature. ${ }^{294}$

The cities were referred to as poleis both by themselves and by the Seleukid king. An example of this is $I G L S$ 1183, from Seleukeia-in-Pieria, which includes a decree of the city and a letter from the king. Both decree and letter explicitly refer to Seleukeia-inPieria as a polis. ${ }^{295}$ As mentioned on page 12 , this does not necessarily mean that the cities of the Seleukid heartland were poleis in the political sense, because the Greeks used the term with topographical and urban meanings aside from the specific socio-political meaning invariably meant by modern scholars. ${ }^{296}$ When the Greeks spoke of the polis in the socio-political sense, as discussed on page 12, they expected it to have the following characteristics: a territory, a sense of community, and self-government. I shall address these three aspects successively, arguing that the new Seleukid foundations also possessed each of these characteristics and were, therefore, poleis in the political sense.

\section{Territory}

There can be no question that the cities of Syria and Mesopotamia possessed territories of their own - a significant amount of modern scholarship is concerned with the distinction between royal and civic land. ${ }^{297}$ Though most of the evidence for the existence of civic land arises from Asia Minor or later periods, there is plenty of evidence that Syrian cities possessed their own territories in the Hellenistic Period. Strabo provides an example in the case of Apameia when he says that the usurper Diodotos:

... received his initial support from that polis and its dependent towns: Larisa, Kasiana, Megara, Apollōnia and others, which all paid tribute to Apameia...

\footnotetext{
${ }^{294}$ Foundations were poleis: Bevan (1902) 1.222; Giovannini (1993) 269; Jouget (1928) 89; Rostovtzeff (1941) 1.483; van der Spek (1987) 57.

Foundations were not poleis: Downey (1961) 112; Ehrenberg (1969) 203; Ma (1999) 229; Runciman (1990) 348.

${ }^{295}$ As does Ptolemaios III in the Garoub Papyrus: BNJ 160 col. 2 \& 3.

${ }^{296}$ Hansen (2000) 180-181.

${ }^{297}$ e.g. Aperghis (2004) 88ff.; Bikerman (1938) 160; Rostovtzeff (1941) 179, 465ff., 481, 493ff.
} 


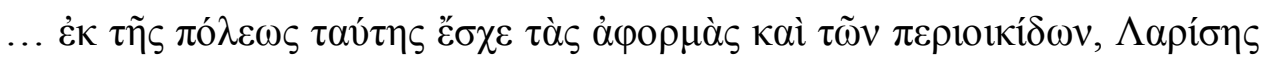

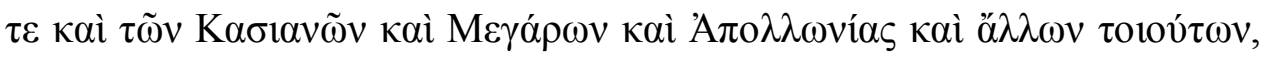

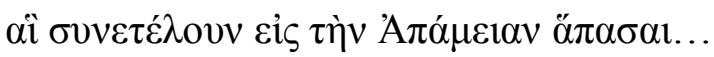

(Strabo 16.2.10)

While $\pi \varepsilon \rho 101 \kappa i ́ \delta \omega v$ on its own is capable of meaning simply 'neighbouring towns,'

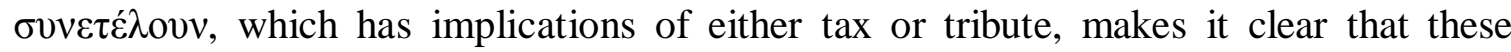
communities formed part of a civic territory of some sort. ${ }^{298}$ Polybios provides another example, which also shows that these hinterlands could be substantial, when speaking of Antiochos III's war prospects after capturing Tyre and Skythos:

...the territory subject to these poleis could easily supply his entire army and provide the full requirements for his expedition.

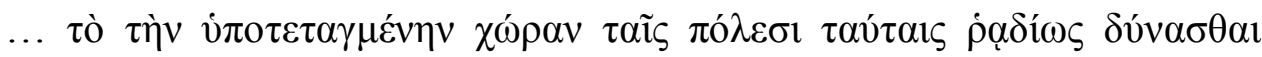

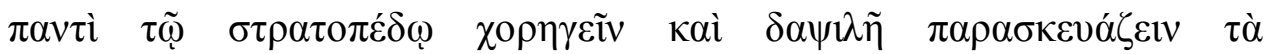

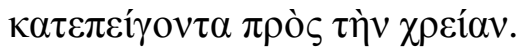

(Polyb. 5.70.5)

The idea of non-royal land was definitely not alien to the Syria-Mesopotamian context the large temples of the region had possessed significant land-holdings since at least the neo-Babylonian period (626-539). ${ }^{299}$ So, Greco-Macedonian precedent was for cities to have territory; local precedent did not contradict that, and there is plenty of evidence that Greek precedent was followed in the case of the Seleukid foundations.

\section{Community of citizens}

The cities of Syria and Mesopotamia, were without a doubt communities of citizens. ${ }^{300}$ In IGLS 3.2.1183, an inscription in Seleukeia-in-Pieria made in 186, Aristolochos, one of the king's friends is made a citizen of the city. This was accomplished by enrolling him in a tribe and deme, just as in Classical Athens:

... he is to be enrolled, by the secretary, as the son of Aristolochos, in the deme of Olympieus and the tribe of Laodikis.

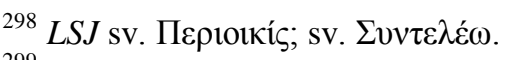

${ }^{299}$ Schaper (1995) 528.

${ }^{300}$ Giovannini (1993) $269 \& 283$.
} 


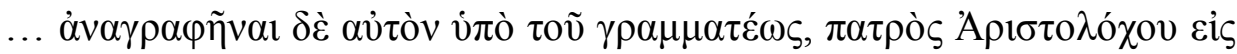

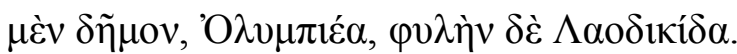

(IGLS 3.2.1183 l.24-25).

The fact that citizenship was given as an honour suggests that it was valued highly, and the need to record Aristolochos' patronymic when he was enrolled further implies that citizenship was determined by descent and was thus exclusive. The Syrian and Mesopotamian cities also regularly made use of ethnic designations, such as "the Antiochenes" and "the Seleukeians." The ethnics occur in inscriptions from the time of Antiochos III onwards and appeared on coins as soon as the first municipal bronzes were issued under Antiochos IV. ${ }^{301}$ Such ethnics are a strong indication that they viewed themselves as community of citizens, rather than simply people at a place. ${ }^{302}$ The case of Ptolemais-Akē provides an example of the strength of these civic identities. Captured from the Ptolemies in 198 and renamed Antiocheia-in-Ptolemaia, the old name of the city lived on and reasserted itself in the middle of the first century BC. ${ }^{303}$ The endurance of the old name suggests a communal identity entirely distinct from Seleukid rule, which the Seleukids were unable to suppress. ${ }^{304}$ Finally, the civic myths of Antioch, including successive foundations by Orestēs, Alexander, and Seleukos, which are well-attested in Libanios, Malalas, and in art, all date back to the Seleukid period, suggesting a desire for myths of identity in that period. ${ }^{305}$ It seems clear, therefore, that the new Seleukid foundations behaved as a community of citizens with a strong communal identity.

\section{Self-Government}

As discussed in chapter one, the classical Greek polis was by nature a self-governing community with some degree of independent action. Many communities of classical Greece which otherwise might have qualified as poleis were usually not viewed as such by their contemporaries because they were simply a subordinate part of a larger community, with no independent sovereign power. The settlements of the Spartan perioikoi are a well-known example. ${ }^{306}$ Strictly following such a definition, no settlement subject to a king, including those of the Seleukid heartland, could ever meet the

\footnotetext{
${ }^{301}$ BMC: Antiochos IV \#38 - 88 (These will be discussed at length in chapter three).

${ }^{302}$ Hansen (1996) $170 \& 190$.

${ }^{303}$ Akē, whence the modern day name of the city, Acre, is derived.

${ }^{304}$ Bagnall (1976) 238; Kindler (1978) 51-53.

305 See page $64 \mathrm{ff}$.

${ }^{306}$ Hansen (1995) 25.
} 
requirements to be a polis in the political sense. Even in the Classical Period, however, very few communities possessed eleutheria according to the wider definitions - most were subject, to a greater or lesser extent, to the most powerful poleis, such as Athens, Sparta, and Thebes. ${ }^{307}$ In practice, the Greeks used the political meaning of polis to refer to any settlement with at least some freedom of action in internal matters. ${ }^{308}$ This included the subordinate allies/subjects of Athens and the Greek cities under Persian rule. ${ }^{309}$ So long as a community had institutions of internal self-governance with some theoretical ability to act according to their own discretion, the community was considered to be a polis. ${ }^{310}$

It is clear that the cities of the Seleukid heartland contained an array of institutions for internal self-governance. ${ }^{311}$ Two decrees, one from Seleukeia-in-Pieria (IGLS 3.2.1183), and another from Laodikeia-by-the-Sea (IGLS 4.1261), indicate that these cities possessed magistrates and assemblies. Both decrees were (officially) enacted by their Assemblies, implying that, in theory, the latter possessed final decision-making power. The forms of a self-governing polis were maintained (the details and independence of these institutions will be discussed in chapter three). ${ }^{312}$ Thus, the Seleukid core cities display evidence of a sense of community, possession of a hinterland, and institutions of self-government. They were poleis, both in the general sense of large conurbations and in the specifically political sense.

\section{Role of the Foundations}

As the Syrian and Mesopotamian poleis were royal foundations, their very existence represents a royal polis policy - they were founded because Seleukos I and Antiochos I thought it to be in their interest to transplant the polis system to the east and they were maintained because their successors thought it in their interests to maintain that polis system. Exactly why they thought that that system was in their interest has been the subject of debate. It is clear that there was an element of self-aggrandisement, of mimicking Alexander and the other diadochoi, ${ }^{313}$ but the locations and scale of the

\footnotetext{
${ }^{307}$ Carlsson (2010) 61.

${ }^{308}$ Hansen (1995) 37.

${ }^{309}$ Ibid., 22, 24, \& 25

${ }^{310}$ Grainger (1990a) 63-65; Hansen (1995) 23.

${ }^{311}$ Bikerman (1938) 143; Mørkholm (1966) 110.

312 Bikerman (1938) 157.

${ }^{313}$ Dunn (2012) 119.
} 
foundations, which far exceed those of the other diadochoi, are not fully explained by this motivation alone. Several other factors have been mooted, none of which are satisfactory on their own and not all of which seem to have been in the minds of the founders, but which together demonstrate the essentiality of the Syrian and Mesopotamian poleis to Seleukid rule.

A common view in the nineteenth and early twentieth centuries was that Hellenistic foundations were primarily intended to spread Greek civilisation. The most notable proponent of this view in relation to the Seleukids was their first modern historian, Bevan, who saw a connection between the Seleukid foundations and the then contemporary colonial venture, explicitly stating "the work being done by European nations... in the East is the same work which was begun by Macedonia and Rome." 314 The popularity of this view declined in tandem with the popularity of the European colonial venture, and it was thoroughly attacked by Sherwin-White and Kuhrt, who were influenced by Edward Saïd's 1978 book, Orientalism. ${ }^{315}$ It can now be considered discredited, though it is unquestionable that the foundations were partially responsible for the spread of Greek art, culture, and technology to the east.

Another old view, partially inspired by analogy with the Roman Late Republic, holds that the foundations were intended for the retirement of veterans. ${ }^{316}$ The Seleukid colonists were indeed veterans, and their settlement did ensure that the Seleukids possessed a source of new Greco-Macedonian soldiers, rather than having to import them from the Aegean basin. ${ }^{317}$ But, Jones notes, there was no reason why they had to be settled in poleis ${ }^{318}$ in Egypt they were largely settled in rural estates. ${ }^{319}$ In the Seleukid system, it appears from evidence at Doura-Eurōpos that veterans received both an urban plot and a rural plot. ${ }^{320}$ That this was a general policy is supported by the letter in Josep. AJ 12.148-52 concerning the settlement of Babylonian Jewish colonists in Lydia and Phrygia under Antiochos III. ${ }^{321}$ In that latter case, the settlement was motivated by

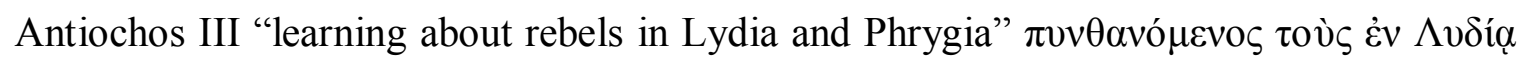

\footnotetext{
${ }^{314}$ Bevan (1902) 1.10 .

${ }^{315}$ Sherwin-White (1987); Kuhrt (1987); Sherwin-White \& Kuhrt, (1993).

316 Cohen (1991) 41.

${ }^{317}$ Billows (1995) 22. Cohen (1978) 8-9; Rostovtzeff (1941) 1.499ff.

318 Jones (1940) 9.

${ }^{319}$ Cohen (1991).

${ }^{320}$ P. Dura 12 \& 15; Cohen (1978) 51ff. discusses the controversies about whether the rural plot was alienable and whether it carried an obligation to military service.

${ }^{321}$ Cohen (1978) 5-9.
} 


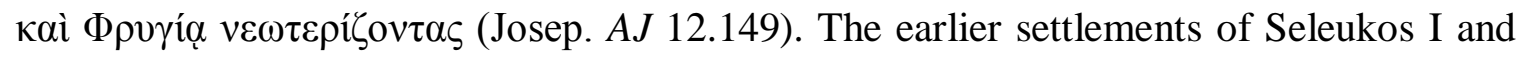
Antiochos I might have had a similar motivation and the fact that Antiochos III deployed colonisation to deal with rebellions in Lydia and Phrygia implies that they were at any rate perceived to have had a positive affect on maintenance of order in the Seleukid heartland. Once the decision had been made to settle the veterans in poleis and komai, however, these settlements became important to the Seleukid military and the need for soldiers was a major factor in the maintenance of these communities. However, both Doura-Eurōpos and Antiochos III's Jewish colonies were far smaller than the Tetrapolis and Seleukeia-on-the-Tigris; ${ }^{322}$ the settlement of veterans alone does not explain these foundations' scale, which as noted above, required that Greeks be imported from the west and natives be resettled in the new settlements alongside the colonists. Nor can the provision of soldiers really be seen as the sole function of the larger foundations for the Seleukid dynasty.

Aperghis argues that the foundations were concentrated in areas which were less heavily urbanised and were "part of a systematic effort to intensify economic activity and generate more silver for the royal treasury" by introducing coinage to the new territories and developing a cash economy which would allow the Seleukid king to collect tax in coin rather than produce. ${ }^{323}$ Aperghis shows that this was a result of the new foundations, in the locations where poleis were established. Aperghis' theory is not a complete explanation, however. It does not explain the foundation of Seleukeia-on-the-Tigris, for Mesopotamia was already full of cities, and surely it would have been cheaper to spearhead the development of a cash economy in Mesopotamia using the mint at Babylon, which had been important since Alexander. Instead the Babylonian mint was phased out in favour of Seleukeia-on-the-Tigris and the Babylonian Astronomical Diaries, which include the daily price of goods at the market, and the cuneiform contracts from Uruk show that the Babylonians continued to use their old system, based on weights of silver rather than coins, throughout the Seleukid period. ${ }^{324}$ Nevertheless, Aperghis demonstrates that the poleis were central to the form of the Seleukid economy in Syria and in northern Mesopotamia - two regions which under the Achaimenids had not been economically important became essential parts of the Seleukid royal economy as a result of the poleis.

\footnotetext{
${ }^{322}$ Doura-Eurōpos was about 45 hectares at its height - a bit over half the size of the Tetrapolis cities at their foundations: Aperghis (2004)

${ }^{323}$ Aperghis (2005) 27; idem (2004) 89-99. Foreshadowed by Rostovtzeff (1941) 157-160.

${ }^{324}$ AD passim, but especially volume 3; Doty (1979) 52.
} 
Grainger took a similar, but more generalised and less economic, approach when he argued that the new foundations were principally intended to solidify control over the new Seleukid territories. ${ }^{325}$ At the foundation of the Tetrapolis, Syria had only just come under Seleukid control, having previously been an Antigonid territory, and was open to attack from Ptolemaic Koile Syria. It was essential for Seleukos to solidify his control over Syria, ideologically, administratively, and militarily, especially as Antigonos' heir Dēmētrios remained at large. ${ }^{326}$ All accounts emphasise that the inhabitants of Antigonos' Syrian capital, Antigoneia, were resettled in either Seleukeia-in-Pieria or Antioch. The fact that the sources cannot agree which city they were resettled in perhaps indicates that they were split among the new settlements. The foundation legends recorded by Malalas and Libanios also mention a large number of local Greeks who were resettled into the new foundations. ${ }^{327}$ Although there had been some Greek settlement along the coast since the eighth century (and some presence since Mycenaean times), ${ }^{328}$ the large number of local Greek settlements which Malalas records is difficult to accept. Perhaps they were actually smaller Antigonid settlements, dressed up with mythic pasts by later generations. The presence of such settlements is supported by the case of Apameia, which was founded on top of a pre-existing settlement called Pella, the Macedonian name of which implies that it was an Antigonid settlement. ${ }^{329}$ By splitting the Antigonid partisans in the region among the new foundations and settling them alongside Seleukid veterans, Jews, and some native Syriacs, ${ }^{330}$ Seleukos diluted their influence in Syria, while working to transfer their loyalty to him. ${ }^{331}$

This factor was probably not at play in the foundation of Seleukeia-on-the-Tigris, because Babylon was notably loyal to Seleukos, revolting in his favour in $311 .^{332}$ Perhaps, however, Babylon's loyalty was constricting. ${ }^{333}$ Babylonian history provided many

\footnotetext{
${ }^{325}$ Grainger (1990a) 54ff \& idem (2010) 57ff. Followed by Billows (1990) 304; Capdetrey (2007) 60; Cohen (2006) 24 \& Sherwin-White \& Kuhrt (1993) 158; Shipley (2000) 289.

${ }^{326}$ Will (1984b) 103-108.

${ }^{327}$ Malalas, 8.202 \& Lib.Or. 11.91

${ }^{328}$ Boardman (2002) 2-3.

${ }^{329}$ Cohen (2006) 94.

${ }^{330}$ Diod. Sic. 20.47.6 \& 21.1.6; Lib. Or. 11.92; Malalas 8.201.

${ }^{331}$ The process has parallels with the transportation and resettlement of conquered populations practiced by the Assyrian and Neo-Babylonian kings.

Dunn suggests Seleukos adopted Dēmētrios' symbols (particularly bull iconography) as his own: (2012) 79. This could reflect Seleukos' efforts to transfer the Antigonid partisans' loyalty to him, alongside his eventual marriage to Dēmētrios' daughter Stratonikē.

332 Diod. Sic. 19.90.

${ }^{333}$ Grainger (1990b) 100.
} 
precedents for the acceptance of foreigners as kings of Babylon, ${ }^{334}$ but a high degree of assimilation to Babylonian mores was expected. ${ }^{335}$ The Seleukids were keen to play the part of a Babylonian king, ${ }^{336}$ but they probably did not want to do so constantly, especially as that would interfere with fulfilling the kingship roles expected by their other subjects. Moreover, the city had not had a king permanently in residence since Nabonidus abandoned the city over two hundred years earlier. ${ }^{337}$ Since that time, the priests of the Esagila and the citizenry had been able to run the city on a day-to-day basis without direct royal involvement. ${ }^{338}$ As a result, they might also have had mixed feelings about the return of the king. ${ }^{339}$ Finally, by moving his palace to a new foundation, Seleukos could avoid giving the other Mesopotamian cities the impression that they were controlled by Babylon. ${ }^{340}$ So, the foundation of Seleukeia was unlikely to displease any party.

Seleukeia was established right on the very edge of the inhabited region in Mesopotamia, bordering the Diyala Plain, between the Tigris and the Zagros Mountains. The meticulous programme of archaeological surveys collated by Robert McC. Adams shows that the Diyala Plain was then almost entirely depopulated and had been for over a thousand years, since the Kassite invasions of the sixteenth century BC. ${ }^{341}$ In the Seleukid-Parthian period, however, its population exploded, increasing by almost $1500 \%$ and its inhabitants moving from nomadic pastoralists to intensive agriculturalists. ${ }^{342}$ The Diyala Plain's transformation from wasteland to breadbasket ${ }^{343}$ was enabled by the improved irrigation technology developed in the Hellenistic and the demand for food created by Seleukeia. Whether Seleukos foresaw that his new foundation would cause the

\footnotetext{
${ }^{334}$ Nearly all Babylonian royal dynasties were of non-Babylonian origin, including that of Hammurabi (Amorite) and Nebuchadnezzar II (Chaldean).

${ }^{335}$ Van De Mieroop (1997) 46.

${ }^{336} A D$-245 A Obv.12-13; BCHP 5 Obv. l.9; BCHP 6; Rostovtzeff (1941) 1.437; Kuhrt \& Sherwin-White (1991) 71-86; Linssen (2004) 19, 85, 108.

${ }_{337}$ Van De Mieroop (1997) 224.

${ }^{338}$ Ibid., $137 \mathrm{ff}$.

${ }^{339}$ The story of the foundation of Seleukeia-on-the-Tigris, in which the priests attempt to mislead the king, have often been taken to represent conflict between Seleukos and his priesthood: Bevan (1902) 253.

${ }^{340}$ On the parochialialism of Mesopotamian cities: Van de Mieroop (1997) 43. The last Babylonian ruler, Nabonidus had held unorthodox religious views and took the gods of all the Mesopotamian cities to Babylon, which posterity viewed very unfavourably (with Achaimenid encouragement): Nabonidus Chronicle: Grayson (1975) 7.iii.9-12; Cyrus Cylinder: Lendering et al. (2010) 32-33; Beaulieu (1993) 243, 254.

${ }^{341}$ Adams (1965) 53ff.

${ }^{342}$ Ibid., 63. This transformation had massive long-term consequences - the centre of gravity in Mesopotamia permanently shifted north, and its produce fed, in turn, Seleukid Seleukeia, Parthian \& Sassanid Ktēsiphōn, Umayyad Kufa, and Abbasid Baghdad.

${ }^{343}$ Plin. NH. 6.122 calls it "the most fertile farmland in the whole east" agrum totius orientis fertilissimum.
} 
development of the Diyala Plain is uncertain - it was not an obviously fertile region and the pre-existing settlement of Ōpis had not had such an affect. ${ }^{344}$ If Seleukeia-on-theTigris was founded while Antigonos was still a major threat, shorter term goals may have been important also. ${ }^{345}$ In that case a major motive for the foundation would have been to rival Antigoneia, which was founded in Syria in 307 (itself, in part, a response to Ptolemaios' Alexandria). ${ }^{346}$ The foundation's placement also allowed it to form part of Seleukos' eastern policy, with the city at the terminus of a redirected Royal Road, which would henceforth pass directly from Babylonia, along the Diyala River through Ekbatana to Mẽdia and Bactria. ${ }^{347}$ The location was particularly appropriate on account of the presence of the royal canal, which connected it to the more heavily populated Euphrates valley. ${ }^{348}$ Bactria and Mēdia supplied essential troops and resources (particularly gold), ${ }^{349}$ so the routes from these territories to Seleukos' borders with the other diadochoi needed to be as efficient and secure as possible. The fact that further poleis were subsequently founded in Mēdia and Bactria supports this analysis. ${ }^{350}$ The foundation of Seleukeia, thus entrenched the shift of the administrative centre of the Near East from Susa and Persis to northern Mesopotamia, which had been begun under Alexander. There was no longer any reason for the royal road to detour through Susa and Persis, or to have administrative machinery in those locales. ${ }^{351}$

Thus, many factors encouraged the foundation and maintenance of poleis, most of which boil down to establishing control and establishing structure in military, political, and economic spheres. The network of fortified settlements created and maintained the essential artery of the kingdom - the route which linked the Mediterranean to Inner Asia,

\footnotetext{
${ }^{344}$ The region is alternately dry and very wet, requiring a great deal of irrigation to conserve water, manage floods, and prevent rises in salinity: Adams (1965) 3ff. There is one potential Mesopotamian precedent for founding a city to develop a new region, in Sargon of Assyria's description of the foundation of DurSharrukin: Van De Mieroop (1997) 60. That city did not outlast its founder and it is unlikely anyone knew of it in Seleukos' day.

${ }^{345}$ On the uncertainty surrounding the date of Seleukeia's foundation see page 49, note 285 , above.

${ }^{346}$ Grainger (1990b) 100; Rostovtzeff (1941) 157.

347 The Ekbatana route, "one of the few natural east-west passes through the long barrier of the Zagros range," had long been in use, but the Seleukids lavished attention on it, razing Ekbatana to the bedrock and rebuilding it from the ground up Stronach (2012) $53 \& 55$.

${ }^{348}$ Hopkins (1972) 5.

${ }^{349} A D-273$ B obv. 31 mentions the passage through Seleukeia of several war elephants from Bactria during the First Syrian War. The enumeration of troops before the Battle of Raphia, at Polyb.5.79, makes clear the reliance of the Seleukid army on forces from Mēdia and northeastern Iran. Seleukid gold mostly derived from Siberia: Rostovtzeff (1941) 1.447.

${ }^{350}$ Ibid., 1.479 .

${ }^{351}$ Which became something of a backwater in this period, but remained part of the Seleukid realm: Wiesehöfer (2011) 110f.
} 
not just militarily, but also commercially and socially. Seleukos' colonisation programme may also have included shorter-term goals, which explain the differences between the two ends of the dumbbell: the desire to match Antigoneia (and Alexandria) encouraged the foundation of a single megalopolis in Mesopotamia, while the need to dilute the Antigonid settlers and block both invasion routes from Koile Syria encouraged the foundation of several smaller poleis in Syria. The foundations had long-term macrohistorical consequences: the introduction of currency to the east and the revitalisation of the Diyala Plain and these long term benefits were also significant to the poleis' foundations and to the kings' continued patronage of the poleis.

\section{Tying Polis to King}

If these poleis were intended to solidify and maintain Seleukid control over new regions and potentially unruly populations, then we might expect to see elements in the poleis designed to ensure loyalty and obedience to the Seleukid dynasty. Such elements do exist: the cities were designed so that they could not easily withstand royal force; to recall Macedon so that the colonists would have less inclination to desert; and their civic identities were tied closely to the Seleukid dynasty, such that expression of polis identity could be achieved by loyalty to the dynasty rather than through opposition to it.

The very design of the cities ensured that the royal garrisons were in control. None of the Syrian cities were defenceless - Ptolemaic armies and Arab raiders frequently ravaged the region, after all. But in all cases, Grainger observed, the citadel, which was home to a royal garrison, commanded by an epi tōn akrophthlakiōn ${ }^{352}$ or an akrophylax, ${ }^{353}$ was external, such that it could be reinforced from outside the city in the case of revolt (unlike, for example, the Athenian acropolis). ${ }^{354}$ The citadel of Antioch, provides an example. A plan of the city in the Roman period sourced from McEvedy is supplied at right. ${ }^{355}$ The city of Antioch sat at the bottom of the steep slope of Mount Silpios. The citadel was located at the top of the slope, so a force threatening the citadel

\footnotetext{
${ }^{352}$ OGIS 254.

${ }^{353}$ Joseph.AJ.13.388; Polyb.5.50.10f. Bickerman (1938) 54 claims that the title phrourarchos was also used, but none of his citations support that.

${ }^{354}$ Grainger (1990a) 62. The only exception is the citadel of the small town on the Euphrates at Jebel Khalid, (just barely) within the city walls on a huge limestone bluff, which provides the best position for monitoring river traffic: Clark (2002a) viii \& 47.

${ }^{355}$ McEvedy (2011) 20. The walls of Tiberius, Theodosius II and Justinian all post-date the Seleukid period, but the wall of Tiberius largely reflects the boundaries of the city by the end of the Seleukid period, except that they (and the walls of Justinian) also enclose a large portion of the slope of Mount Silpios, which has never been inhabited owing to its steepness.
} 
from the city would be utterly unable to dislodge the garrison. ${ }^{356}$ The slope on the other side of Mount Silpios is very shallow, making it easy to reinforce the citadel from outside the city, but also meaning that the citadel was only really effective for countering attacks from the city. Antioch was completely indefensible against external attack - down to the time of the Crusades, there is not a single example of the city withstanding a siege. ${ }^{357}$ It is difficult to believe that Seleukos, hardened general that he was, unintentionally established an indefensible city - apparently, the ability to dominate the settlement was more important than being able to defend it against external attack (it is the furthest of the Tetrapolis from the Ptolemaic border, so this would not be entirely unreasonable). In Mesopotamia Seleukeia-on-the-Tigris seems to have been poorly defended - it could not have survived very long under siege on account of its size, anyway. ${ }^{358}$ In other cases, defence against external attack appears to have assumed a higher priority. For example, Seleukeia-in-Pieria's citadel, sitting atop the Koryphaion, a massive massif, was "a remarkable stronghold, and too strong to be

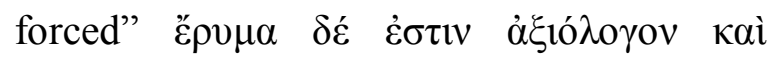

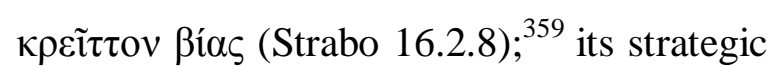
position made such defences a necessity. ${ }^{360}$

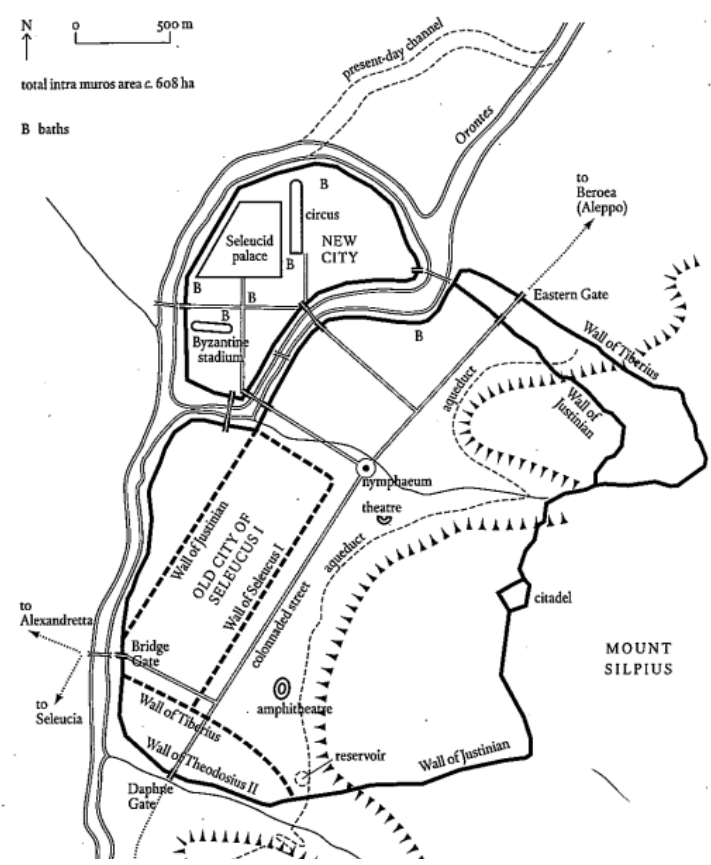

Antioch in the Roman period:

McEvedy (2011) 20

But again, the prime defensive position was occupied by the citadel, which would have held a royal garrison. The city was far below and separately walled, linked to the citadel by a single narrow staircase carved into the cliff-face ${ }^{361}$ - a situation which Antiochos III

\footnotetext{
${ }^{356}$ Downey (1961) $17 \& 65$; an Arabic chronicle of the eight century incorrectly assumes that the entire mountain must have been included within the walls from the beginning, because the alternative (the reality that at its foundation the citadel was fortified separately) was unbelievable on tactical grounds: Codex Vaticanus Arabicus 286, 2.5ff.

${ }^{357}$ Downey (1961) $17 \& 65$.

${ }^{358}$ McNicoll (1997) 102. He suggests that mudbrick walls probably existed (none have yet been found) and that the Tigris would have formed a defensive barrier against attacks from the east. There is no evidence for a citadel - the land is too flat (aside from what is either a free-standing theatre or a ziggurat). Mesopotamian practice would be to garrison troops in the (as yet unexcavated) palace - perhaps that model was followed at Seleukeia.

${ }^{359}$ Cf. Polyb. 5.59.4-10.

${ }^{360}$ Downey (1961) 62; McNicoll (1997) 83; Pompey refused to even attempt a siege: Strabo 16.751.

${ }^{361}$ Elderkin, Stillwell \& Waage (1941) 3.5.
} 
was able to exploit to recapture the city from Ptolemaic control in $219 .^{362}$ The design of the cities, fortified against their own inhabitants as much or more than against external attack, thus "says volumes about the expectations of king and citizens." ${ }^{363}$ Should it come to it, the design of the poleis would enable the king to compel them by force.

However, compulsion by force is hardly a sustainable long-term policy - it tends to cause a great deal of collateral damage, beget further unrest, and occupy armies which could be better deployed elsewhere - it was a last resort, not the ideal. ${ }^{364}$ Seleukos worked to make the new poleis not gaols but homes to the settlers - Syria would be a New Macedon. ${ }^{365}$ Making Syria feel familiar would prevent homesick colonists from defecting, as the Bactrian colonists had after the death of Alexander. ${ }^{366}$ The Seleukids thus strongly identified themselves, their foundations, and their regime with Macedon their efforts are reflected by later historians' frequent references to the Seleukid realm as "Macedonian," a term which they did not use for the Ptolemaic kingdom. ${ }^{367}$ Many landmarks, places and sub-regions were renamed after Macedonian analogues, such as Pieria, named after the region around the Axios delta in Macedon. ${ }^{368}$ The place names perhaps owe as much to the colonists as Seleukos, but the Macedonian elements were not limited to place names; the cities were poleis on the Greek model (with which the Macedonians were familiar by the fourth century), ${ }^{369}$ and made use of Macedonian magistrates like the epistatēs and the peliganes (discussed in detail in chapter three). These elements also existed at Seleukeia-on-the-Tigris, but from the beginning, the latter also had non-Greco-Macedonian elements. That city was, from the outset, settled in part by inhabitants of Babylon and many aspects of the city were designed to appeal to them there was an archive for cuneiform contracts, for example. ${ }^{370}$ These aspects represent the same policy with a different audience ${ }^{371}-$ a New Babylon as well as a New Macedon. ${ }^{372}$

\footnotetext{
362 Polyb. 5.60.

363 Grainger (1990a) 87.

364 Ma (1999) 9.

365 Dunn (2012) 123; Rostovtzeff (1941) 479.

${ }^{366}$ Diod. Sic. 18.7.

${ }^{367}$ Edson (1958) 164. Musti strongly criticises taking this as indicating the Seleukid empire had a greater "grado di macedonicità" (degree of Macedonian-ness) than the other kingdoms, but accepts Edson's conclusions as far as I have taken them here: (1966) 112-138.

${ }^{368}$ Cohen (2006) 26; Jones (1940) 9; Rostovtzeff (1941) 479.

${ }^{369}$ Hatzopoulos (1996) 70, 108, \& 219.

${ }^{370}$ Centro Richerche Archeologiche e Scavi di Torino, "Seleucia on the Tigris," www.centroscavitorino.it/en/progetti/iraq/seleucia.html (Accessed 25/9/2012).

${ }^{371}$ An example of the king's willingness to conform to the expectations of multiple audiences, as discussed above, pages 9-11.
} 
Essentially then these new settlements had everything that the colonists might miss from home, but bigger and better, ${ }^{373}$ encouraging the settlers to remain in place rather than attempt to return to Macedon.

\section{Giving the Poleis a Seleukid Identity}

It was important that the colonists stay put, but it was vital that they did so as loyal subjects of the Seleukid dynasty. To that end, Seleukos and his successors worked to connect the poleis' identities to the nascent Seleukid dynasty, so that expression of polis identity and loyalty to the dynasty could be one and the same thing. An obvious but important manifestation of this strategy was the very names of the communities. Of the Tetrapolis, Seleukeia and Antioch were named after Seleukos and his son, the future Antiochos I. ${ }^{374}$ Each came to be the cult centre for one of dynasty's patron deities: Zeus at Seleukeia and Apollo at Antioch, who were identified with Seleukos and Antiochos respectively. ${ }^{375}$ The other two poleis were named after Seleukos' mother Laodikē and his wife Apama (Antiochos' mother). All used the Seleukid royal dating system. ${ }^{376}$ Most of the many other foundations received similar names, with the populace referring to

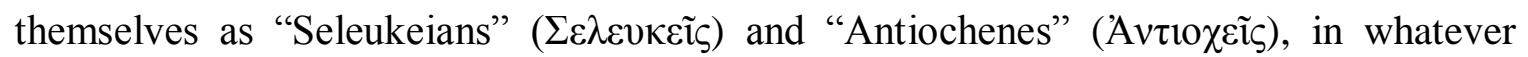

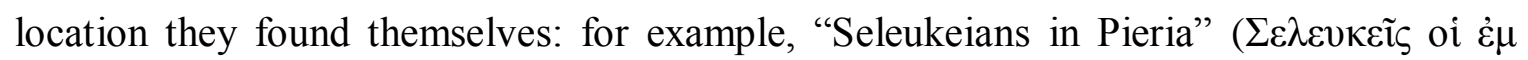

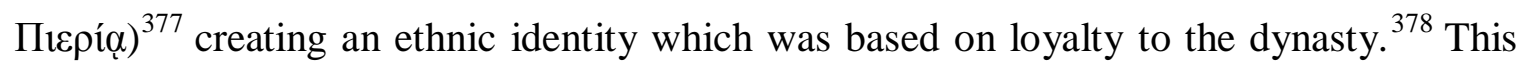
strategy is also visible in the ongoing Seleukid practice of renaming native cities as Seleukeia or Antiocheia, which did not necessarily involve actually settling many (or any) Greeks in the city. ${ }^{379}$

This loyalist identity was more than just a name: a nexus of myths was established emphasising the Seleukid role as founders. These myths are most fully recorded in the sixth century chronographer Malalas, who represents a local tradition, as discussed above

\footnotetext{
${ }^{372}$ The lack of similar Syriac elements in the poleis of the Tetrapolis would then suggest that Syriacs were not resettled thither in the same quantity.

373 Poseidonios, FHG 3.258.

${ }^{374}$ App. Syr. 57 and Strabo 16.2.4 say that Antioch was originally named for Seleukos' father, but he was an absolute historical non-entity, and if the city ever was identified with him, that identification co-existed with an identification with Antiochos I from the reign of Antiochos I. The Antiochenes' foundation legend identified Antiochos I as their namesake: Malalas, 8.200.

${ }^{375}$ IGLS 3.1184 lists a priest of "Seleukos Zeus the Victor and Antiochos Apollo the Saviour ( $\Sigma \varepsilon \lambda \varepsilon v ́ \kappa o v$

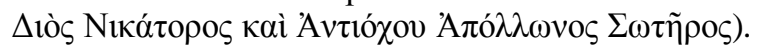

${ }^{376}$ Laodikeia: IGLS 3.2.1183; Seleukeia-in-Pieria: IGLS 4.1261.

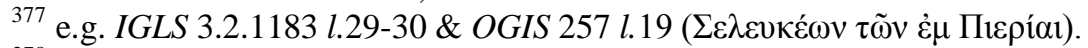

${ }^{378}$ Compare the use of similar ethne for actual ethnic groups, e.g. "The Sidonians at the Port of Jamnia"

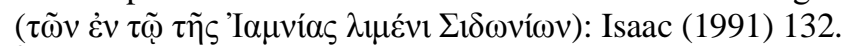

${ }^{379}$ E.g. Susa (Seleukeia-on-the-Eulaios), Jerusalem (Antiocheia), Ptolemais-Akē (Antiocheia in Ptolemais).
} 
(page 45). His account of the Tetrapolis foundation myths is in accord with the more abbreviated versions found in art and Libanios Oration 11. Of the foundation of Seleukeia-in-Pieria, Malalas records:

[Seleukos] came to sacrifice on Mount Kasios to Zeus Kasios, and having completed the sacrifice and cut the meat, he prayed, asking where he ought to found a polis. Suddenly, an eagle snatched [the meat] away from the sacrifice ... Seleukos ... ran down after it and found the meat thrown by the sea below the ancient polis, in the trading station of the area called Pieria. Immediately he surrounded it with walls, threw down foundations, and named this polis Seleukeia - after his own name.

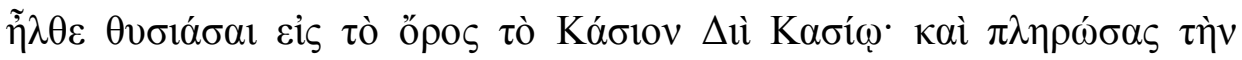

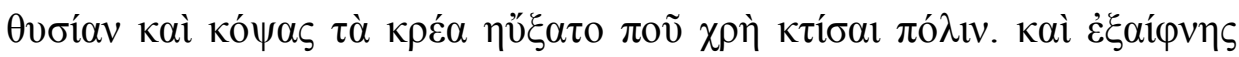

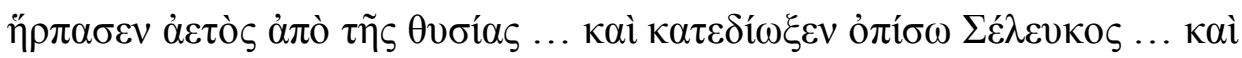

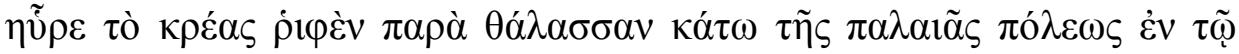

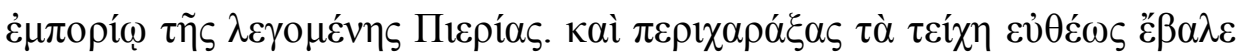

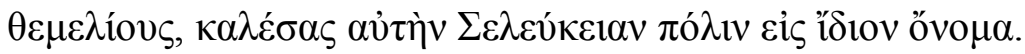

(Malalas 8.199)

The same story is repeated, with slight variations, for each of the poleis. The account does a couple of important things. Firstly, it associates the local cult of Mount Kasios with Seleukos and his dynasty - Seleukos and his foundations are divinely favoured. ${ }^{380}$ Secondly, it associates the polis with the eagle, which as the animal of Zeus was a prominent Macedonian and Seleukid symbol. ${ }^{381}$ Libanios adds that Seleukos used elephants, another prominent Seleukid symbol, to mark out the walls of the new city of Antioch. ${ }^{382}$ Both animals were already Seleukid symbols, for they regularly appear on royal coinage from the time of Seleukos I. ${ }^{383}$ The link between these symbols and the cities was commemorated by monuments and on items associated with the city, such as

\footnotetext{
${ }^{380}$ Rostovtzeff (1941) 1.437.

${ }^{381}$ Dunn (2012) 48, who cites Just. Epit. 12.16.4-5 as an example of the eagle's earlier use to legitimise Alexander.

${ }^{382}$ Lib. Or. 11.90: "Sketching out the city, he stood his elephants at intervals throughout the territory of

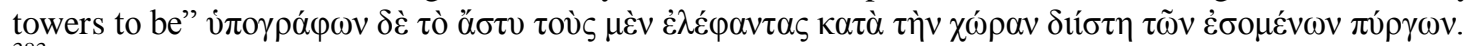

${ }^{383}$ Early examples: eagle, SC 36 (Seleukos I, Laodikeia-by-the-Sea); elephant: SC 35 (Seleukos I, Apameia) \& SC 14 (Seleukos I, Antioch). Both symbols also serve to link Seleukos with Alexander, Dunn (2012) 48 $\& 63$.
} 
weights. ${ }^{384}$ Each king was added to the foundation cult in their lifetimes - the obligations which the cities owed to Seleukos as founder thus vested in Seleukos' successors. ${ }^{385}$ The depth to which these myths and founder cults penetrated the civic psyche can be seen by their endurance - in the second century AD, Laodikeia-by-the-Sea and Doura-Eurōpos still had priests of the Seleukids, ${ }^{386}$ at which time the name Seleukos was still popular among the leading families of Doura-Eurōpos; ${ }^{387}$ monumental representations of the Seleukid foundation myth have been found from the first or third century AD near Laodikeia-by-the-Sea and at Doura-Eurōpos; ${ }^{388}$ and Malalas himself lived in the sixth century.

There is some evidence for Seleukeia-on-the-Tigris and Mesopotamia (none of it narrated by a local, unfortunately), from which it seems likely that the same strategy was used there as well. For example, Pliny claims that:

The placement of the walls [of Seleukeia-on-the-Tigris], truly, [resembles] the outstretched wings of an eagle...

situm vero moenium aquilae pandentis alas...

(Plin.NH.6.122)

In fact, the outline of the polis bears very little resemblance to an eagle, ${ }^{389}$ so it seems likely that the resemblance was not a natural observation, but an idea propagated by the Seleukid kings. Seleukeia-on-the-Tigris also had its own foundation legend, mentioned by Appian, in which the magi give an inauspicious hour for the foundation of the city, but Seleukos' soldiers are miraculously inspired to begin building the city on the auspicious hour. ${ }^{390}$ This story, then, also focuses on showing that the king and his new foundation are favoured by the local gods, but, as preserved by Appian, contains no Seleukid symbols. Nevertheless, this myth (and those told in Syria) firmly tied the poleis' identities to the Seleukid dynasty and served to remind the poleis of the enormous debt which they owed to the dynasty. Later kings stressed their links with the founding kings of the

\footnotetext{
${ }^{384}$ Rostovtzeff (1941) 1.452 and eventually coins, see page 69-76.

${ }^{385}$ IGLS 3.1184, a priest list from Seleukeia-in-Pieria in the reign of Seleukos IV includes two priests of the kings from Seleukos I to Seleukos IV, who are listed in full in the priests' titles.

${ }^{386}$ Laodikeia: OGIS 263; Doura-Eurōpos: Rostovtzeff (1935) 58.

387 Johnson (1932) $17 \mathrm{ff}$.

${ }^{388}$ Seyrig (1940) 343; Rostovtzeff (1941) 1.424.

${ }^{389}$ Hopkins devotes a whole paragraph and a diagram (of an eagle trussed rather than rampant!) trying to work out how the outline of Seleukeia's walls could possibly be taken for an eagle: (1972) $1 \mathrm{f}$.

${ }^{390}$ App. Syr. 9.58.
} 
dynasty by reusing the names Seleukos and Antiochos and the early Seleukid epithets and thereby maintained this personal relationship. ${ }^{391}$ Whereas the dynasty had to make gifts of special status to put the cities of Asia Minor deep in their debt (as discussed in Chapter one), the Syrian and Mesopotamian poleis were constantly reminded that they were indebted by the very fact of their foundation.

\section{Antiochos IV's New Foundations}

It seems that the desire to extend this special relationship throughout his realm was behind Antiochos IV Epiphanēs' renaming of a number of Mesopotamian and Syrian native cities as Antiocheias and Epiphaneias. ${ }^{392}$ The significance of these name changes is hotly debated; they were once held up as evidence of Antiochos' efforts to spread Hellenism, ${ }^{393}$ but it is now often doubted whether they were anything more than a rebranding exercise. ${ }^{394}$ They seem to have indicated at least the nominal refoundation of these cities as Seleukid poleis (or the foundation of poleis within the native city), ${ }^{395}$ and they were accompanied by building works, such as the renovation and expansion of the theatre at Babylon. ${ }^{396}$ Whether they involved the settlement of Greeks is unclear; Antiochos potentially had partisans to resettle from Asia Minor, which had been lost to the Romans under his father. The Babylonian Astronomical Diaries make reference to a group called lúpu-li-ța-nu, ${ }^{397}$ a transliteration of the Greek politēs ( $\pi \mathrm{o} \lambda \dot{i} \tau \eta \varsigma$ ), citizen, suggesting a group of Greek speakers in a polis. ${ }^{398}$ In other cases, however, there seem to have been only Hellenising locals. ${ }^{399}$ Although this is the context from which the verb

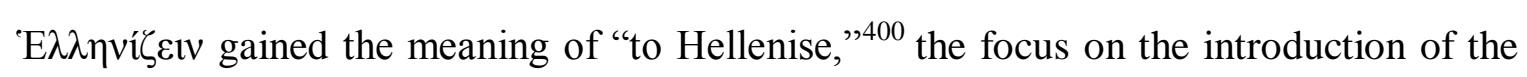

\footnotetext{
${ }^{391}$ e.g. OGIS 253, discussed below, in which Antiochos IV is given the epiphets $\Theta[\varepsilon 0 \tilde{v}]$ and $\sigma \omega \tau \tilde{\eta} \rho \circ$, shared with Antiochos II and I respectively.

${ }^{392}$ Mørkholm (1966) 116.

${ }^{393}$ Rostovtzeff (1941) 1.64.

${ }^{394}$ Musti (1984) 200.

${ }^{395}$ Rostovtzeff (1941), 2.703.

${ }^{396}$ Mørkholm (1966) 118.

${ }^{397} A D-162$ Rev. 11-12 (163 BC) is the earliest instance.

${ }^{398}$ Kuhrt (1987) 66. The continued activity of the traditional Babylonian officials and of the Esagila Temple implies that for the city's native inhabitants, Babylon continued to operate much as before, leading Sherwin-White \& Kuhrt to suggest that Babylon had not been refounded as a Greek polis, but had had a polis founded within it: (1993) 256-258.

399 The most conspicuous example is Jerusalem, whose refoundation as an Antioch is described in I Macc. 1.13-15 and II Macc. 4.9-14. Like everything relating to Jerusalem, the meaning and accuracy of these accounts is extremely contentious. There are many discussions, but most treat Antiochos' Jerusalem policy in isolation from his policy to other centres and assume that Jerusalem loomed as large for Antiochos as it does for us, e.g. Gruen (1993); Morgan (1993).

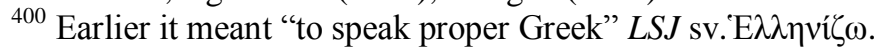


dynastic names, the cult of Zeus Olympios, ${ }^{401}$ and the Macedonian-style petasos hat $^{402}$ suggest that the process is better understood as Seleukidisation; ${ }^{403}$ the intention seems to have been to create the same coincidence of civic and dynastic identities which had already been established in the Tetrapolis and Seleukeia-on-the-Tigris. The clearest example of the centrality of this link to the whole project is OGIS 253, which was inscribed somewhere in north or central Mesopotamia ${ }^{404}$ to commemorate games held in conjunction with the Festival at Daphnē, ${ }^{405}$ says:

During the reign of Antiochos [IV] the g[od], saviour of Asia and foun[der] of the polis, at the thanksgiving games of the year [1]44, on the [third day] from the end of Hyperberetaios, Philip dedicated a [gift] to [Antiochos] the god manifest[t]...

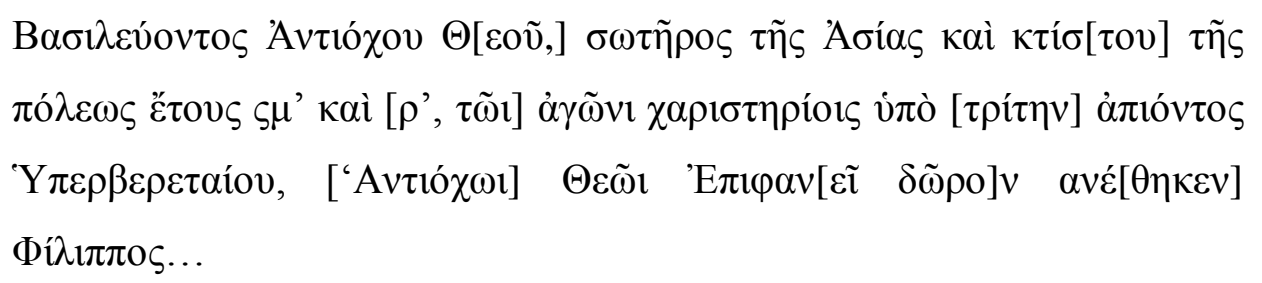

(OGIS 253 l.1-7)

This inscription makes clear the central role which the king could have in a polis as its founder: it is an inscription about an offering made to Antiochos, during a festival for Antiochos, dated by reference to the reign of Antiochos, and it especially emphasises his role as founder (and saviour - an inflated reference to his failed invasion of Egypt). The reception of this policy among the native populations who made up the majority of the inhabitants of these cities varied. In the Mesopotamian cities, it might have suggested an equation of the Seleukid king with the local patron deity, the traditional founders of these cities, with whom their fates were intimately intertwined. ${ }^{406}$ At Jerusalem the local

\footnotetext{
${ }^{401}$ II Macc. 6.2. There is dispute about whether this cult was insitituted in all Antiochos IV's refoundations, or just at Jerusalem, for the same passage reports that the sanctuary of the Samaritans at Gerezim was reconsecrated to Zeus Xenios: Gruen (1993) 252.

402 II Macc. 4.12.

${ }^{403}$ Rigsby (1980) 238.

404 This inscription, along with OGIS 254, is traditionally attributed to Babylon. However, as it was purchased from a dealer in Baghdad in the nineteenth century (who would profit for items from Babylon more than from elsewhere), that provenance is not at all secure: Sherwin-White (1982) 65.

${ }^{405}$ Mørkholm (1966) 100.

${ }^{406}$ Van De Mieroop (1997) 47. All Mesopotamian cities were understood to have been founded by their gods - There was no native tradition of mortals founding cities (Sargon of Assyria's description of the foundation of Dur-Sharrukin represents only a partial exception in that though he stressed his role as founder, the city did not survive him): ibid., 53-61.
} 
response, especially among those who dwelt in the city's hinterland was extremely negative. ${ }^{407}$ There, the policy sparked the Revolt of the Maccabees and ultimately led to the complete independence of Judaea from Seleukid control. Jerusalem seems to be the only place where the policy provoked such a strong negative response, however. Even if things did not go according to plan in Jerusalem, the fact that Antiochos IV tried to extend the Seleukid polis model from the new foundations to the native settlements implies that the model was functioning to encourage loyalty to the dynasty in the new foundations. He would hardly try to spread the polis model if it had proven disloyal elsewhere.

\section{Coinage and Minting}

Coinage was a potential indicator of polis identity which became increasingly important in the Hellenistic period. Significantly, coinage of Syria and Mesopotamia was overwhelmingly royal in iconography and minting was controlled by the kingdom. A result of the way that the Seleukid kingdom was stitched together from the realms of several different diadochoi was that, from the very beginning, there were mints throughout the Seleukid realm - Houghton and Lorber identify at least thirty-nine separate mints operating under Seleukos I, which were slowly consolidated under his successors. ${ }^{408}$ Most scholars agree that, for the Greeks, the minting of coinage was bound up with ideas of the eleutheria and autonomia. ${ }^{409}$ It is important, therefore, that these early Seleukid mints produced their coins in the name of the king. Production of coinage in the early Hellenistic seems to have been instigated by the kings, controlled by the kings, and for the benefit of the kings, whether the specific benefit be the payment of mercenaries, encouraging colonisation, ${ }^{410}$ assertion of authority, ${ }^{411}$ or as part of an effort

\footnotetext{
${ }^{407}$ Why this should have been so is well beyond the purview of this thesis (Jerusalem is not in the Seleukid heartland) and has been discussed inconclusively and at length in the scholarship. For a review see Shipley (2000) 307-312.

${ }^{408}$ Houghton \& Lorber (2002) 1.1.11ff.

${ }^{409}$ An influential exception, Martin (1985) will be addressed on page 74.

${ }^{410}$ Houghton \& Lorber (2002) 1.1.5.

${ }^{411}$ Ibid. e.g. Seleukos I's issues in Syria, which had already been flooded with Alexander-types by a succession of diadochoi and "had no particular need for new money." Asserting sovereignty in this way was an especial concern for illegitimate rulers: Antiochos Hierax (SC 873-886), Molōn (SC 949-951), and Achaios (SC 952), all took care to produce silver/gold issues of exceptional quality. By contrast, Antiochos III did not even bother to mint silver in his newly spear-won territories of Koilē-Syria \& Judaea: Houghton \& Lorber (2002) 1.1.409.
} 
to replace the payment of tax in kind. ${ }^{412}$ There were no civic coins in the Seleukid heartland until late in the period, and then only very erratically.

There is some evidence that there was local demand for coinage: during the disordered period following the death of Seleukos I, the minor, but well-excavated, colony of Doura-Eurōpos seems to have run out of bronzes and "a crude and possibly unofficial local mintage" ${ }^{413}$ was issued locally to fill the gap. This implies that even at this very early stage in Doura-Eurōpos' history, coinage had already established itself as an economic necessity and minting cannot, therefore, be viewed as an entirely ideological phenomenon. Local factors did have important practical impacts on coinage, as demonstrated by Kitt's massive statistical analysis of all the Seleukid royal bronzes, which shows that the denominations issued varied wildly, both geographically and chronologically. In Kitt's view, this must indicate the influence of local and temporal circumstances. ${ }^{414}$ Nevertheless, the supply of these coins was entirely controlled by royal officials, as demonstrated at Doura-Eurōpos by the fact that every coin was countermarked by royal officials before entering circulation. ${ }^{415}$ The picture, then, is one of royal dominance and control of minting.

However, there is some regional variation in coin designs, often taken to indicate some kind of local involvement or control over the minting process, which could then have been connected to polis sovereignty. It is clear that Greeks of Asia Minor took pride in being able to put their own civic symbols on their coins - a decree from very early Roman Sestos in Asia Minor records that the decision to mint bronzes was taken,

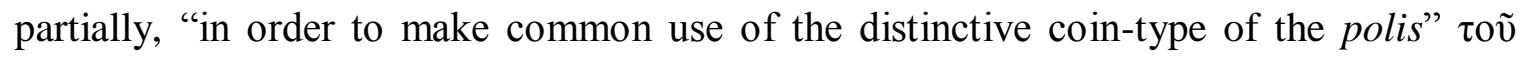

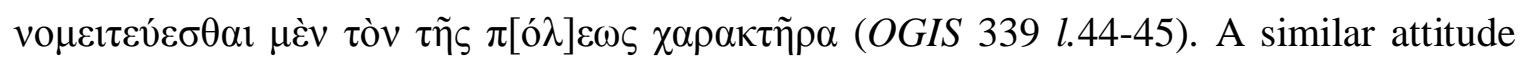
presumably existed elsewhere. ${ }^{416}$ There are two kinds of regional variation on Seleukid coins: variation of the main motifs and the use of local civic symbols as mintmarks. Variation of the main obverse and reverse motifs is common on issues from Asia Minor and Bactria - especially from the reign of Antiochos II. $^{417}$ In the case of Bactria, they indicate the gradually increasing independence of the satrap Diodotos from royal

\footnotetext{
${ }^{412}$ Aperghis (2004) 29-32.

${ }^{413}$ Kitt (2002b) 1.2.41.

${ }^{414}$ Idem (2002a) 1.2.6-36.

415 The fact of local issue is based on the uniqueness of the countermarks and their discovery at, and only at, Doura-Eurōpos: Bellinger (1949) 197; SC 363-368.

${ }^{416}$ Melville-Jones (1972) 40.

${ }^{417}$ Houghton \& Lorber (2002) 1.1.168.
} 
power. ${ }^{418}$ Unlike these loosely-held regions, the issues of the Seleukid heartland almost always used standard royal motifs for their main images. Minting and the selection of main motifs was directed from the centre, as shown by the fact that the same motifs often occur throughout all or most of the kingdom. ${ }^{419}$ Central control of numismatic motifs is further demonstrated by the kings' ability to quickly change coin motifs throughout the empire - for example, Antiochos II completely replaced the Apollo-omphalos type with the Apollo-tripod type throughout the realm almost immediately after his accession. ${ }^{420}$ The main motifs, then, were firmly under the control of the Seleukid kings.

The second type of variation was the use of parasema (civic emblems) as mintmarks on the royal silver minted at a particular centre and was particularly common in Asia Minor. ${ }^{421}$ These tiny symbols appear only at some mints and only under some kings. For instance, they all spontaneously disappear at the beginning of Seleukos II's reign, only to reappear in some cases under his rebellious brother, Antiochos Hierax. ${ }^{422}$ The implication is that they reflect an ongoing process of status negotiation, undertaken afresh with the accession of each new king. ${ }^{423}$ There are relatively few cases of this practice east of Taurus - mostly from old native communities: the foreparts of a horse at Ekbatana in Mēdia, ${ }^{424}$ a bucranium at the sanctuary of Bambyke ${ }^{425}$ and a grape cluster or a club on Tarsian coins. ${ }^{426}$ The most persistent of these, the Ekbatanan horse, was also a Seleukid royal symbol. ${ }^{427}$ The only example from a new foundation is Laodikeia-by-the-Sea, which displayed a dolphin mintmark from its foundation in 300 until c. $245 .{ }^{428}$ But Laodikeia-by-the-Sea's coins are generally unusual - they were consistently modelled on the types issued under Alexander and were issued in greater quantity than any other mintage of the period; oddities which are probably related to their status as the Seleukid

\footnotetext{
${ }^{418}$ Holt (1999) 97ff.

${ }^{419}$ e.g. Seleukos I's bronze bull \& Medusa-types found in the 280s at almost every mint between Sardis (SC 6) and Aï Khanoum, Bactria (SC 290).

${ }^{420}$ Houghton \& Lorber (2002) p. 232.

${ }^{421}$ e.g. Lysimacheia's lion (SC 481-483); Ilion's Athena Ilias (SC 488) vs. Sardis, which under Antiochos II had no mintmark on silver and gold (SC 517-19) and various royal symbols as mintmarks on bronzes (SC 520-31).

${ }^{422}$ Houghton \& Lorber (2002) 1.1.231; examples: 239ff \& 297ff.

${ }^{423}$ Ibid., 1.1.166.

${ }^{424}$ SC 200-216 onwards: Horses from Nēsaia in Mēdia had been famous since Achaimenid times: e.g. Hdt. $3.106 .2 \& 7.40 .4$

${ }^{425}$ SC 38: Continuing a pre-Seleukid local coinage issue: Houghton \& Lorber (2002)1.1.27.

${ }^{426}$ SC 330 \& SC 332.1, respectively

${ }^{427}$ The Seleukid horned horse motif, in particular, however, seems to be concentrated at first in the issues from Ekbatana - perhaps it was a local emblem which was rapidly appropriated by the dynasty?

${ }^{428}$ Beginning with SC 36-37 and ending with SC 576. Image of SC 36 overleaf, from WildWinds.com http://wildwinds.com/coins/greece/seleucia/seleukos_I/SC_036@4.jpg (Accessed 23/06/2013)
} 
trade currency in the Eastern Mediterranean. ${ }^{429}$ In place of parasēma, many royal bronze issues from the Seleukid heartland were countermarked with the Seleukid anchor - if the

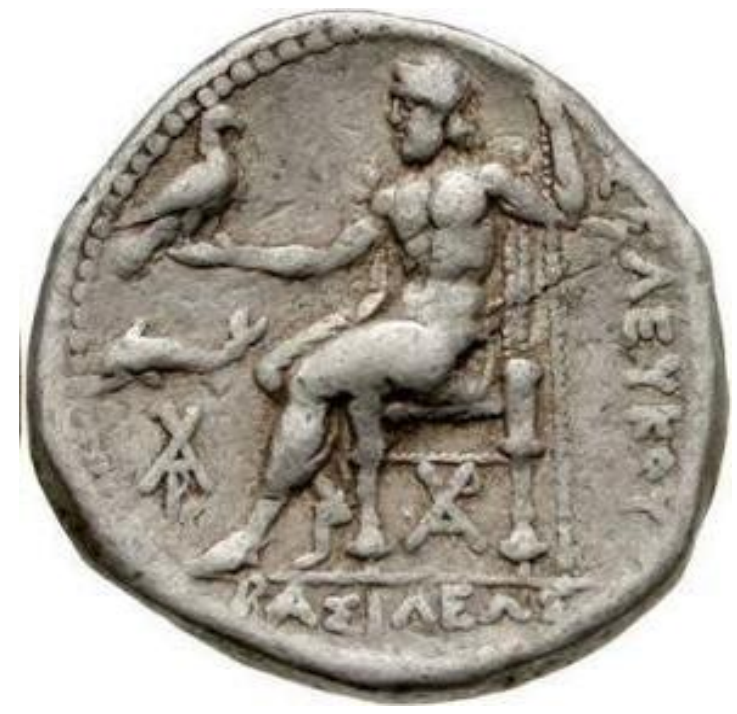

Dolphin at left: $S C 36$ obverse, from wildwinds.com

grant of parasēma indicates some sort of sovereignty, then these Seleukid emblems would presumably indicate the opposite. ${ }^{430}$ However, the parasema are tiny and to take them as central indications of civic status seems to exaggerate their importance. More likely, their absence from the coins of the new foundations simply reflects the fact that the new foundations had no traditional civic emblems aside from Seleukid symbols like the anchor. Thus the presence of anchors and other Seleukid symbols in place of parasèma may be a result of the the Seleukid dynasty's efforts to make royal symbols a central part of civic identity.

\section{Civic Coinage}

The significance of using local parasema on coins for the cities of Asia Minor is believed

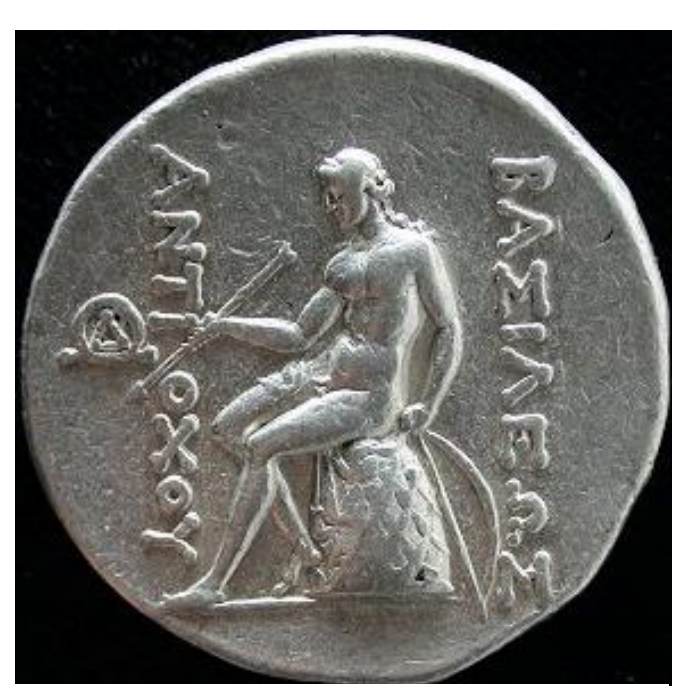

One of the monograms at left: $S C 335.4 \mathrm{c}$ obverse, from wildwinds.com.

to be the fact that they symbolised some sort of civic involvement in the minting process. Despite lacking parasēma, it appears from Antiochene issues under Antiochos I and II that the new foundations did sometimes enjoy such involvement in fact. Each year's issue of these coins bears a unique monogram. ${ }^{431}$ Monograms usually indicate the royal official in charge of the mint in question. They typically appear for several issues and are often attested from multiple mints as the official was transferred from one mint to another. Thus, the consistently annual monograms at Antioch are quite

\footnotetext{
${ }^{429}$ Houghton (1999) 180.

${ }^{430}$ e.g. SC 339 from Antioch under Antiochos II.

${ }^{431}$ SC 335; SC 571-2. Image of SC 335.4c from WildWinds.com http://www.wildwinds.com/coins/greece/ seleucia/antiochos_I/SC_335@4c.jpg (accessed 24/06/2013)
} 
odd. Houghton and Lorber argue that they point to a period in which there was an annual mint magistracy - and annual terms are the hallmark of civic magistracies. ${ }^{432}$ These coins, then, indicate some civic involvement in the production of the royal coinage at Antioch. ${ }^{433}$ If such a boon was granted by kings Antiochos I and II, then it was targeted at the civic elite, who could potentially hold the magistracy and advertise themselves. The kings before Antiochos IV pointedly did not grant a civic coinage bearing the community's symbols and ethnic, which would have proclaimed that the polis was in control of its own finances.

The only possible examples of civic coinage of that type in the Seleukid heartland, at this early stage, were minted from $300 \mathrm{BC}$ at Arados, the Phoenician island city, and they are the exception that proves the rule. A number of factors, including its naval power, defensible island location, and the Seleukid conflict with Dēmētrios Poliorkētēs, had allowed Arados to gain extensive autonomy from a very early date. ${ }^{434}$ It also had preexisting traditions of self-rule and civic coinage, ${ }^{435}$ which Seleukos' foundations lacked. ${ }^{436}$ Further, the early Seleukids had some interest in allowing Arados some autonomy, in order to act as an intermediary in the trade between the Seleukid realm and the other cities of Phoenicia, which were wealthy but under Ptolemaic control. ${ }^{437}$ Despite all these factors, in the early period, even the Aradian coins were blazoned with the Seleukid anchor, and the ethnic of the community did not appear. Seleukos II granted Arados autonomia in 242, in the aftermath of the war he waged to take the Seleukid throne. Thereafter, Arados issued coins in the name of Alexander (SC 927), dated by a unique Aradian era. ${ }^{438}$ By 138/7 Arados was issuing its municipal silver coins on its own weight standard and in its own name. ${ }^{439}$ These coin issues were thus fairly clearly civically organised. However, Arados is the only city in the Seleukid heartland for which coinage suggests an early and complete movement towards independence from the

\footnotetext{
${ }^{432}$ Houghton \& Lorber (2002) 1.1.xxi.

${ }^{433}$ Rostovtzeff (1941) 1.448

${ }^{434}$ Capdetrey (2007) 212; Grainger (1990a) 65 \& 145ff.

${ }^{435}$ Grainger (1990a) 53.

${ }^{436}$ Rostovtzeff (1941) 1.156.

${ }^{437}$ Seyrig (1970) 300.

438 These coins might have been permitted by the king, in part, to replace the Alexander-type trade coins of Laodikeia-by-the-Sea which had ceased by this time, though those had always been issued in the name of the Seleukids: Houghton (1999) 181.

${ }^{439}$ Mørkholm (1984) 102.
} 
Seleukid monarchy ${ }^{440}$ and this movement reflects circumstances which did not apply to the other poleis of the heartland.

\section{Semi-Civic Coins of Antiochos IV and Alexandros I}

The only comparable phenomenon for the other cities of Syria is some brief but enigmatic issues of Antiochos IV. These appeared, suddenly and briefly, in 169/8 at the beginning of Antiochos IV's reign. Nineteen of the Syrian cities began issuing bronze coins bearing their civic ethne and civic symbols (in some cases quite unusual) on the reverse, and the king's image, but not his name, on the obverse. ${ }^{441}$ Before this issue there had been no civic coinage in Syria, and the issues only lasted a few years in most places and none lasted into the reign of Antiochos V. A second batch was issued between 151 and 148, in the early reign of Antiochos IV's supposed son, Alexandros I Balas. ${ }^{442}$ That they were issued all at once implies an initiative of the central government; that the designs and weights differ implies that the individual cities chose the designs.

The connotations of these issues are debated. According to the so-called lex Seyrig, Greek cities only issued coins in their own name if they were free or highly autonomous. ${ }^{443}$ Downey, therefore, thought that these issues represent weakening Seleukid control over the Syrian cities and prefigure the collapse of the Seleukid realm. ${ }^{444}$ It is difficult to believe that these coins represent grants of complete independence because all these civic coins depict Antiochos IV on their obverse, because many of the mints continued to issue normal royal bronzes alongside these civic issues, ${ }^{445}$ and because of the short duration of the issues. ${ }^{446}$ Martin attacked the lex Seyrig, using evidence from Macedonian-ruled Thessaly to argue that coinage was issued primarily for economic reasons and had almost no ideological significance whatsoever. ${ }^{447}$ In that case, there ought to be clear economic reasons for these issues. Bronzes could be lucrative for the poleis, because the nominal value of the coins exceeded the cost of the materials and labour required to make them, a link which the Greeks were aware of, as demonstrated by

\footnotetext{
${ }^{440}$ Grainger (1990a) 145.

${ }^{441}$ BMC: Antiochos IV \#58-85; Mørkholm (1966) 129.

${ }^{442}$ BMC: Alexander I \#59-69; Hoover (2001) 23.

${ }^{443}$ Thus named by Mastrocinque (1980-1981) 62, and popularised/attacked by Martin, (1985).

444 Downey (1961) 121.

445 Mørkholm (1961) 66.

${ }^{446}$ Idem (1984) 101.

${ }^{447}$ Martin (1985) esp. 163; Accepted by Oliver, "Politics of Coinage," 38.
} 
an inscription from early Roman Sestos in Asia Minor. ${ }^{448}$ The coins might then represent a royal gift of this means of income to the cities. ${ }^{449}$ However, Heuchert notes that, in general, the profits from issuing bronzes might not be spectacular, as they were "only small change." ${ }^{450}$ Profits would have been particularly limited in this case, because the kings continued to issue royal bronzes alongside the civic ones (eating into the potential profits) and because many of these issues were extremely limited: those of Cilicia and Askalōn are now attested by only one or two coins each. ${ }^{451}$ Nor does it explain the novel iconography. ${ }^{452}$ As discussed above, civic officials seem to have been put in charge of minting royal bronzes in earlier times - why not simply do this again and assign the profits from those issues to the cities? It thus seems unlikely that potential profits were the sole reason for the production of the coinage.

Thus, the imagery on these coins must be significant. The audience for this imagery must have been the polis of origin in most cases, because bronze coinage generally circulates locally. ${ }^{453}$ Significantly, the imagery recalls both the royal and civic spheres simultaneously. For example, the obverses all display the image of Antiochos IV, a clear expression of loyalty to him. However, on most of the issues Antiochos is depicted wearing a radiate crown, a symbol of divinity, ${ }^{454}$ which for the Syrian poleis was closely linked with his status as their founder's heir. Most of them depict Zeus on the reverse, ${ }^{455}$ a patron of the Seleukid dynasty, in forms familiar from royal coinage. He was also identified with the gods of the many Syriac cult centres of the region, including that of Zeus Kasios who features prominently in Malalas' rendition of the Tetrapolis' foundation myths and could therefore be interpreted as a local symbol. ${ }^{456}$ Other poleis' issues have reverses which are apparently civic emblems. For instance, some of Seleukeia-in-Pieria's coins feature the thunderbolt, ${ }^{457}$ which was the object of a civic cult. The issues of Laodikeia-by-the-Sea consistently depict Zeus-Poseidon holding a

\footnotetext{
${ }^{448}$ Bellinger (1949) 6.188; OGIS 339 l.45: gives, as one reason for minting, "the accompanying profit from

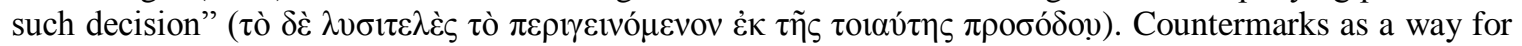
local administrations to protect these profits: Kitt (2002b) 1.2.42.

${ }^{449}$ Hoover (2001) 23; Mørkholm (1984) 102.

${ }^{450}$ Heuchert (2005) 32.

${ }^{451}$ Mørkholm (1961) 64.

452 The issues of the Phoenecian cities and Syrian sanctuaries, in particular, feature many unprecedented symbols: Wright (2009/2010) 296.

${ }^{453}$ Of the Syrian poleis, the only exception is Antioch, whose bronze issues were used by smaller settlements, even at some distance, such as Doura-Eurōpos: Bellinger (1949) 11.

${ }^{454}$ Pollitt (1986) 32ff; Smith (1988) 42.

${ }^{455}$ BMC: Antiochus IV \#61-81; 86-87; Alexander \#59, 63-65; 68-69.

${ }^{456}$ Malalas 8.199.

${ }^{457}$ BMC: Antiochus IV \#83-84
} 
dolphin, ${ }^{458}$ appropriate for a city whose connection with the sea was embedded in its very name. Several of Alexandros' issues from Seleukeia-in-Pieria and Antioch bear the legend "of the brother demoi" $\dot{\alpha} \delta \varepsilon \lambda \varphi \tilde{\omega} v \delta \eta \dot{\mu} \mu \omega v$ on the reverse, and busts on the obverse, which may be Zeus and Apollo and/or personifications of the two dēmoi. ${ }^{459}$ All of these images would resonate as civic symbols, but also as royal symbols. The Seleukeian cult of the thunderbolt had been founded by Seleukos I at that polis' foundation, ${ }^{460}$

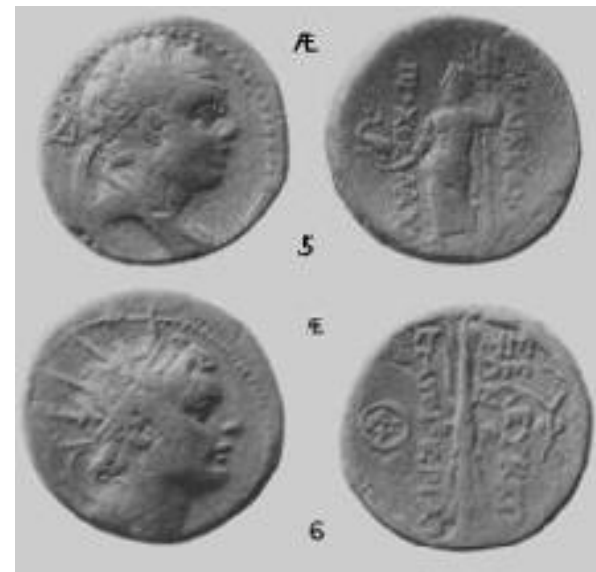

Top: Laodikeia-by-the-Sea:

$B M C \# 82$ courtesy of BMC

Bottom: Seleukeia-in-Pieria:

$B M C \# 83$ courtesy of BMC Laodikeia's Zeus-Poseidon and dolphin recalled a similar image used on her royal bronzes, ${ }^{461}$ and Seleukeia and Antioch were only brothers because of their shared foundation by Seleukos I. ${ }^{462}$ These images contrast quite strikingly with the simultaneous issues of the Phoenician cities which were part of the same phenomenon and likewise featured Antiochos IV on the obverse, but largely featured images recalling their pre-Seleukid history and cults on the reverse. ${ }^{463}$ The imagery on the Syrian poleis' coins is significant, therefore, as an example of how the Syrian poleis could express their identity as poleis and their loyalty to the Seleukid dynasty simultaneously. They affirm the centrality of Seleukid-ness to the Syrian poleis' identities.

\section{Conclusion}

There were three aspects to the Seleukid polis policy. The garrisons and structure of civic fortifications meant that obedience could be maintained by force, if necessary, but this was a poor basis for ensuring ongoing loyalty to the dynasty. That was better achieved by structuring the new foundations in the familiar form of the polis and particularly by

\footnotetext{
${ }^{458}$ BMC: Antiochus IV \#82; Alexander I \#66-67.

${ }^{459}$ GCS: Antioch on the Orontes \#1-11. Rigsby convincingly quashes the idea that these represent an ephemeral Syrian League: "Seleukid Notes" $242 \mathrm{ff}$.

${ }^{460}$ App. Syr. 9.58.

${ }^{461}$ From $S C 36$ (her very first issues) onwards.

462 "the four poleis $[\pi$ ó $\lambda \varepsilon 1 \varsigma]$... which were called siblings of each other on account of their concord, as

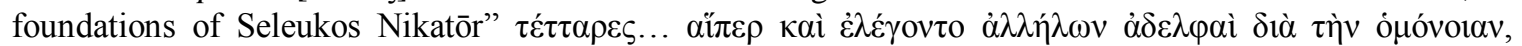

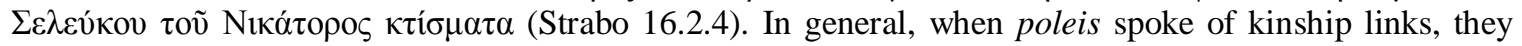
understood those links as reflecting colonisation: Jones (1999) 14 \& 60 .

463 e.g. Byblos' issues featuring Kronos-El in the strikingly non-Seleukid and non-Greek form of a seraph: Wright (2009/2010) pl.6.5.
} 
linking symbols of polis identity to the Seleukid dynasty so that expressions of polis identity were also expressions of loyalty and indebtedness to the dynasty. The program was extended to a number of native cities under Antiochos IV. The semi-civic coins of Antiochos IV and Alexandros I are a clear example of this form of expression in practice. While the dynastic names of the foundations of Alexander and the other diadochoi might reflect a similar policy, the Seleukid programme far exceeds these others in scale. It would only be matched by the coloniae founded in the names of Caesar and the Roman emperors in the Imperial period. 


\section{CHAPTER THREE: THE KING AND HIS POLEIS}

This chapter analyses the ways in which the relationship between the new foundations and their king functioned. Although the Seleukid foundations were poleis in form, and by their nature were therefore entitled to a degree of self-government, ${ }^{464}$ it is, as Grainger notes, "remarkably difficult to find any Syrian city which acts in an independent way." "465 To a certain extent, this depends on the degree of independence we look for; if compared to Classical Athens, the Seleukid foundations are always going to look subservient; if on the other hand they are compared to what we know of Alexandria and Ptolemais-Hermiou in Ptolemaic Egypt, which apparently had no organs of self-government whatsoever, ${ }^{466}$ the Seleukid foundations look significantly more independent. The king could and did interfere deeply with the inner operations of the poleis, apparently without outcry, ${ }^{467}$ but the cities sought - and achieved - a degree of independent agency. In this respect they were similar the poleis of Asia Minor, but unlike the poleis of Asia Minor they sought only limited self-government, not full independence.

\section{Royal Interference in Polis Affairs}

The most obvious manifestation of royal power in the poleis were the Seleukid garrisons. As discussed above, the garrisons were the ultimate means of ensuring royal control over the poleis. In Western Asia Minor, some cities were left ungarrisoned, ${ }^{468}$ but in Syria and Mesopotamia garrisons seem to have been everywhere and were often massive. They exercised a great deal of control over their communities. An example is offered by Polybios, who recounts that, at the beginning of Antiochos III's reign, the chief minister Hermias plotted against Epigenēs, a prominent royal friend and resident of Apameia by planting a treacherous letter in his house:

After this had been done, Alexis [the garrison commander, or akrophylax, of Apameia] was on the scene immediately and cross-examined Epigenēs, asking whether a letter had been brought from [the rebel] Molōn. When Epigenēs strongly denied this, Alexis asked to search the premises. Quickly entering, he found the letter, which he used as grounds to execute

\footnotetext{
${ }^{464}$ Mørkholm (1966) 110.

${ }^{465}$ Grainger (1990a) 65.

466 Bagnall (1976) 8.

${ }^{467}$ Musti (1984) 205.

${ }^{468}$ Ma (1999) 118f.
} 
Epigenēs on the spot. Afterwards, the king was persuaded that Epigenēs had been justly killed and the men of the court, though suspicious of the affair, stayed silent out of fear.

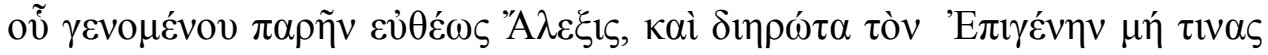

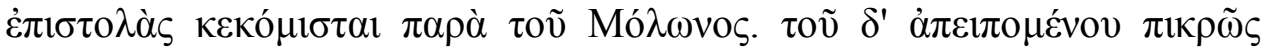

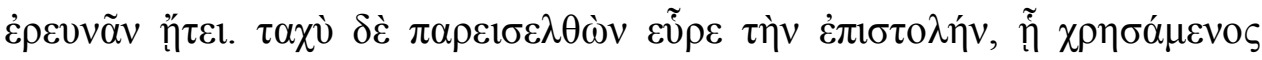

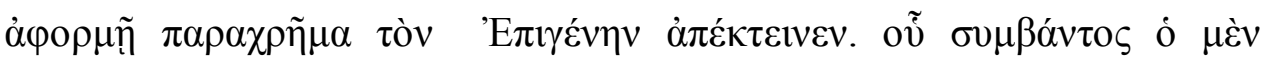

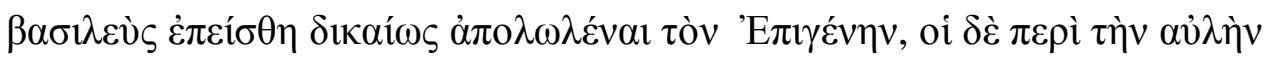

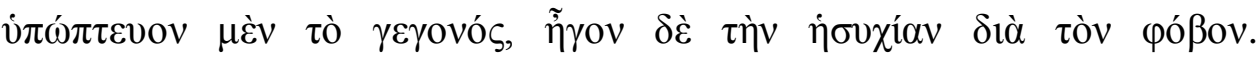
(Polyb. 5.50.10-14)

The tenor of the passage and, particularly, its repeated emphasis on the speed with which Alexis acted $(\varepsilon \dot{\theta} \theta \dot{\varepsilon} \omega \varsigma \ldots \tau \alpha \chi \grave{v} \ldots \pi \alpha \rho \alpha \chi \rho \tilde{\eta} \mu \alpha)$ make it clear that Alexis' actions were inappropriate. However, the affair is presented as an outrage on account of the disregard shown for natural justice, not because royal forces had interfered in the civic sphere. Further, the decision of what to do about the outrage fell entirely to the king, which does not bespeak civic freedom. The lack of response from the Apameians might indicate that such interferences were normal or unobjectionable to them, ${ }^{469}$ or it might simply be that Polybios did not care to record the city's response. That the case was brought to the attention of the king probably reflects the fact that Epigenēs had been a royal friend rather than any concerns about Alexis' jurisdiction. Thus, the passage demonstrates how severely royal agents could interfere in the polis, but not whether this instance was typical or atypical.

\section{Antiochos IV, Agoranomos}

Royal intervention was not limited to acts of terror. Kings could also engage in campaigns of official interference. The reign of Antiochos IV provides several examples of such interference. The most infamous are Antiochos' attempts to be elected as a municipal official of Antioch:

And often, disregarding kingliness and donning the toga, he went through the agora, canvassing for a magistracy and, shaking hands with some and embracing others, he exhorted them to give him their vote, sometimes to

\footnotetext{
${ }^{469}$ Bikerman takes this passage as evidence that the akrophylakes had authority over civic justice: (1938) 163
} 
be agoranomos, sometimes to be demarchos. Having achieved the magistracy and sitting on an ivory chair, according to Roman custom, he witnessed the contracts of those who happened to be in the agora and made judgments with great zeal and enthusiasm. By these things, he led the reasonable people into confusion: Some assumed that he was stupid and others that he was insane.

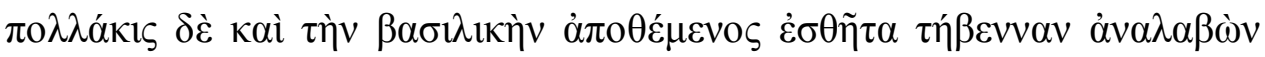

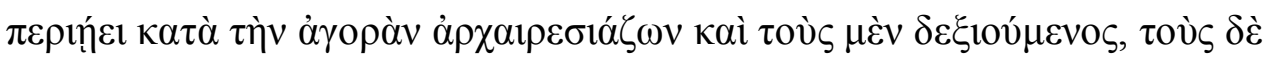

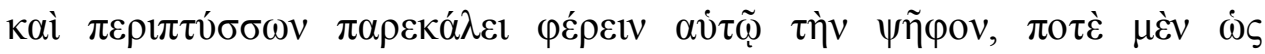

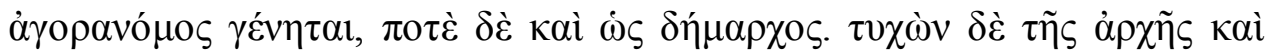

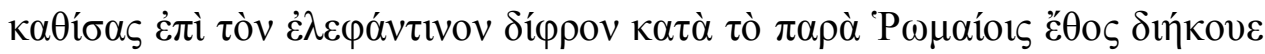

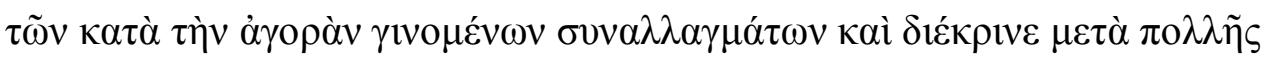

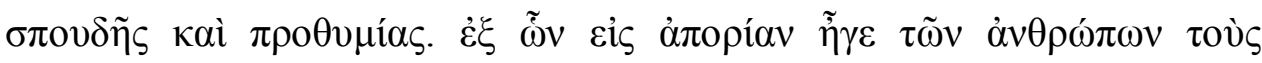

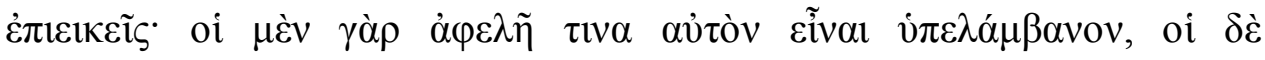

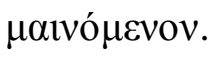

(Polyb. 26.1.5-7).

Mørkholm saw this is part of an effort "to instil in the minds of the citizens that kind of public spirit which [Antiochos] had seen in Rome" ${ }^{470}$ and, thus, a deep intervention into Antioch's civic sphere. However, it is hard to know how seriously to take this story - the conclusion of the passage, "some assumed that he was stupid and others that he was insane" does not inspire confidence in the account's neutrality. If someone had wished to subvert Antiochos, this story was an effective way to do it, for it neatly combines the two major criticisms of his character - that he did not behave with sufficient dignity and that he was a Roman sympathiser. Both charges are highlighted in the opening line of Polybios' rendition of the story, "disregarding kingliness and donning the toga..." Moreover, the civic roles which Polybios says Antiochos took on were low status and labour intensive. The description of Antiochos "witness[ing] the contracts of those who happened to be in the agora and mak[ing] judgments," broadly agrees with the description of the agoranomoi in Aristotle ${ }^{471}$ and with their presence on a number of

\footnotetext{
${ }^{470}$ Mørkholm (1966) 40.

${ }^{471}$ At Athens, according to Arist.[Ath.Pol.] 51.1, agoranomoi were appointed "to manage all the sales"

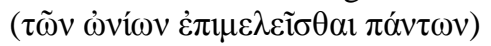


Seleukid civic weights. ${ }^{472}$ It is hard to believe that Antiochos would take on such a mundane role or that he would have had the time to fulfil its duties. However, in the Hellenistic Period, agoranomos could be given as an honorific title to someone who provided grain for the populace - the city might (speculatively) have awarded him the title in gratitude for a gift of grain and the appointment have been twisted subsequently by his enemies. Finally, even if Antiochos did do these things, it is unclear that Antioch was the main audience. Like his later Festival at Daphne, this pageant might well have been intended for a Roman audience. ${ }^{473}$ If, for example, the event's place in Polybios' narrative reflects its chronology, Antiochos IV might have been intending to advertise his philo-Romanism so that the Romans would not object to his seizure of the throne or his campaign against Egypt.

\section{The Chreophylax and Royal Tax}

As a slur, the story could also indicate dissatisfaction with another, more institutional, type of royal intervention in the polis. This was the requirement, extended by Antiochos IV, that certain types of contract be witnessed - and taxed - by a royal agent, called the

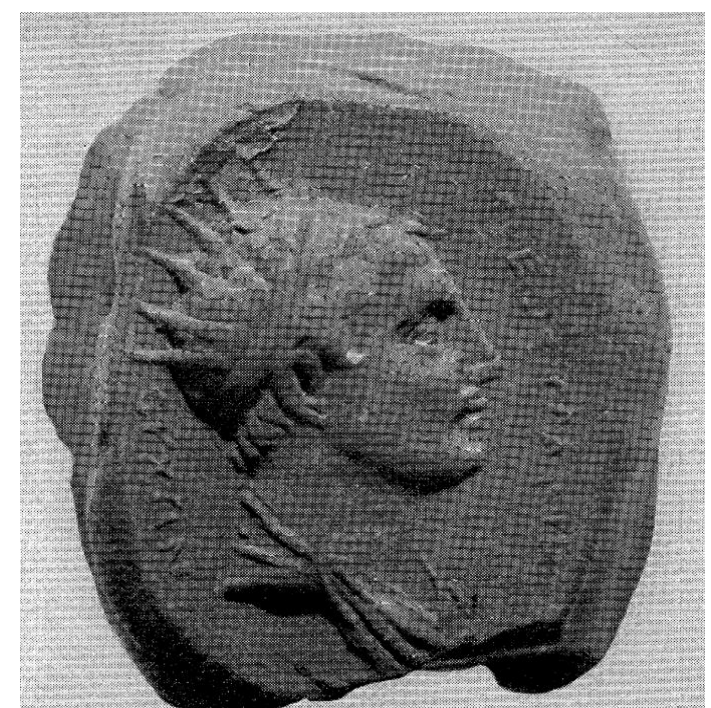

Seal on clay bulla: Rostovtzeff (1932) \#67 chreophylax. We know of this arrangement from archaeological evidence: bullae belonging to chreophylakes have been found at Uruk, and roughly ten thousand more in the archive at Seleukeia-on-the-Tigris; these bullae are rolls of clay which were wrapped around papyrus contracts in order to seal them - they are essentially sealings. ${ }^{474}$ The practice of sealing contracts with bullae was limited to Babylonian communities (and Seleukeia-onthe-Tigris), but a regular sealing found at Jebel Khalid demonstrates that the office of chreophylax was more widespread. ${ }^{475}$ Many of the bullae from Uruk and Seleukeia-on-the-Tigris also bear stamps reflecting taxes on transactions, though not all - for which reason, Aperghis argues that the chreopylakes

\footnotetext{
${ }^{472}$ Rostovtzeff (1941) 1.454.

${ }^{473}$ Antiochos IV seems to have been frequently concerned with Roman opinion: Morgan (1990) 51.

${ }^{474}$ The Uruk seals are collated in Rostovtzeff (1932). On the Seleukeia-on-the-Tigris bullae see Bollati, Messina \& Mollo. 2004. Seleucia al Tigri: Le impronte di sigillo dagli Archivi. Alessandria, Italy: Edizioni dell'Orso, which I have not been able to consult.

${ }^{475}$ Clark (2002b) 202.
} 
were just municipal witnessers of contracts, like those known from Parthian DouraEurōpos, whom contracting parties could optionally make use of in order to provide greater surety to their transactions. ${ }^{476}$ However, the seals clearly belonged to a royal official - not only do many depict Antiochos IV, but they do so in the same style as royal coins, as in the example at left. ${ }^{477}$ Furthermore, there are references at Uruk to " ${ }^{\text {li }}$ mukin šarri, "royal witnessers" 478 - either the chreophylakes were municipal officials and the lum mukin šarri were a separate set of royal witnessers at Uruk (who would then have left no archaeological trace), or "lú mukin šarri was the Akkadian term for the chreophylakes (who would otherwise be unattested in cuneiform records). ${ }^{479}$ The latter seems far more likely - in which case, the meaning of the Akkadian title confirms that the chreophylakes were royal officials. The contracts which the chreophylakes' bullae sealed do not survive, but Doty correlated the sealings on bullae with the sealings on contemporaneous cuneiform contracts stored in the temple archive at Uruk and shows that different types of seal (which also appear on the bullae) reflect different types of contract. Doty notes that the cuneiform contracts for the sale of slaves disappear suddenly in the reign of Antiochos IV, while bullae for slave sales continued, and suggests that this disappearance was caused by Antiochos IV making the witnessing of contracts for sale of slaves obligatory in order to facilitate a royal tax on the slave trade. ${ }^{480} \mathrm{He}$ further notes that the variety of contract types represented in the later cuneiform contracts is very limited, suggesting that the number of kinds of contract which did not have to be registered in Greek on papyrus with the chreophylax was eventually highly restricted. ${ }^{481}$ Especially given that cities had their own civic institutions for witnessing contracts, forcing the use of a royal system represented a substantial interference in the everyday life of the poleis.

The Seleukid kings, then, could interfere in the inner life of the new foundations with an impunity that strongly contrasts with their careful approach to the poleis of Asia Minor. The cases of Alexis at Apameia and Antiochos IV at Antioch are prominent examples of the king and his officials interfering in the civic sphere, though it is difficult to judge how typical they are. In practice, the kings clearly felt no compunction interfering deeply in the internal affairs of these poleis by installing their own agents to

\footnotetext{
${ }^{476}$ Aperghis (2004) 286.

${ }^{477}$ Rostovtzeff (1932) 63.

${ }^{478}$ Kuhrt (1996) 54.

${ }^{479}$ Kuhrt (1996) 54.

${ }^{480}$ Doty (1977) 333.

${ }^{481}$ Ibid.
} 
oversee civic commerce and collect royal taxes. However, though royal interference could be deep and intensive, it was limited. The new foundations all possessed their own, non-royal institutions and, therefore, had the ability to administer themselves and their affairs independently of the kings.

\section{Epigraphic Evidence}

While the tentacles of the Seleukid monarchy undoubtedly interfered in the internal functions of the Seleukid foundations, both arbitrarily and institutionally, the Seleukid foundations did have their own internal institutions mimicking those of the traditional poleis (as discussed above, page 54). However, those institutions did not necessarily operate as they had in Classical poleis. The extent to which these institutions possessed jurisdiction over important matters and operated independently of the kingdom is unclear.

Two decree inscriptions, IGLS 4.1261 from Laodikeia-by-the-Sea and IGLS 3.2.1183 from Seleukeia-in-Pieria, are of particular relevance for determining the independence of the poleis' institutions. The two decrees show a number of parallels which suggest that the institutional systems of the two poleis were broadly similar. IGLS 4.1261 concerns the implications of a civic tax, and provides evidence for civic autonomy in internal matters. IGLS 3.2.1183 of $186 \mathrm{BC}$, already referred to above on page 54, concerns honours to Aristolochos, a royal friend and official granted by Seleukeia-inPieria in response to a letter from the king; in the process, several institutions are mentioned or seen in action. The decrees were both ostensibly issued by the polis in question. They both take the structure of an ordinary civic decree. In and of itself, this need not be deeply significant - in the Hellenistic Period, many polis-like communities, such as military colonies, produced inscriptions vaguely modelled on civic decrees. ${ }^{482}$ The spread of the decree model testifies to the vitality of the polis ideology and its infiltration of new and lower-order communities, but the forms found in such smaller order communities tend to be far less elaborate and generally interact with satraps and hyparchoi (district governors) of the kingdom's hierarchy than the decrees of full poleis.

IGLS 4.1261 and IGLS 3.2.1183, on the other hand, are not shallow imitations of civic decrees, but as elaborate as any decree of Hellenistic Athens or Milētos. ${ }^{483}$ Both

\footnotetext{
${ }^{482}$ E.g. Wörrle (1975) 59-87. Further discussion: Cohen (1978) $25 \mathrm{ff}$.

${ }^{483}$ On the formulae of Hellenistic decrees, Cf. Ma (1999) 183; McLean (1972) 218-232; Woodhead (1967) 38-39.
} 
consist of a single, exceptionally long sentence, presented as the indirect speech of the decree's proposer, who is named at the head of the decree. The language used in such decrees is very elaborate and formulaic - particularly for honorific decrees, like IGLS 3.2.1183, in which the impressiveness of the decree's language formed part of the honour. Both consist of a preamble in two very long clauses, the first, which begins with غ̇ $\pi \varepsilon i$ ("whereas" or "since"), provides specific background for the decree, while the second, beginning with ö $\pi \omega \varsigma$, is the hortatory, which provides the general reason for action, e.g. why the city honours people; by its nature this section tends to be very formulaic. The hortatory is followed by an enactment formula, usually $\varepsilon \delta o \xi \varepsilon v \tau \tilde{\omega} \delta \eta \dot{\eta} \mu \omega$ ("it seemed good to the people"), which officially brought the decree into force. Often, as in both of these decrees, this enactment formula was elided into the following section, which begins with the citation formula $\delta \varepsilon \delta \delta$ ó $\theta \alpha$ ( ("be it resolved"), and states what action the polis has decided will be taken. Both decrees are dated by the Seleukid calendar and era, another indication of the way in which Seleukid symbols were incorporated into the identities of these poleis - cities in Asia Minor generally used their own individual dating systems, or a special Anatolian calendar. ${ }^{484}$ Thus, IGLS 4.1261 and IGLS 3.2.1183 are proper civic decrees of some complexity, not mere imitations - yet more evidence that the Seleukid foundations were actual poleis.

\section{IGLS 4.1261 of Laodikeia-by-the-Sea}

IGLS 4.1261, from Laodikeia-by-the-Sea is the less elaborate of the two decrees, probably because it is concerned with an internal legal matter, whereas IGLS 3.2.1183 is a flowery gift of honours. Sosin reconstructed the context for the decree as follows: the polis had passed a law, requiring people to pay a fee for dedicating theoric statues on public land. Rather than comply, people flocked to dedicate their statues in a private sanctuary, whose owners, fearing that their sanctuary would be ruined by overcrowding, petitioned the civic magistrates and the epistatēs to act. The decree itself is the response of the epistatēs and magistrates - they amended the law so that a fee would also have to be paid to dedicate statues in the private sanctuary. ${ }^{485}$ The inscription thus demonstrates that the Laodikeians were permitted to make and amend laws on some internal matters, including religion and taxation. This control was real enough for the owners of the sanctuary, who were in need of real relief, to appeal to the polis officials in the first place.

\footnotetext{
${ }^{484}$ Bikerman (1938) 145; McLean (1972) 169.

${ }^{485}$ Sosin (2005).
} 
This should not be seen as just jurisdiction over matters too minor for the king to care about. The ability to levy taxes implies control over a treasury (potentially substantial given that the decree was motivated by the vast amount of dedications being made). ${ }^{486}$ Moreover, religious matters were of central importance to classical poleis, ${ }^{487}$ as they were essential to the prosperity of the community and included often contentious matters of public welfare and entertainment. ${ }^{488}$ Thus, Laodikeia possessed real power to act autonomously in regard to matters of central concern to its inhabitants. ${ }^{489}$

\section{IGLS 3.2.1183 of Seleukeia-in-Pieria}

IGLS 3.2.1183 is also a decree, honouring Aristolochos, a royal friend, with citizenship and a statue in the bouleuterrion. Unlike IGLS 4.1261, it is the response to a letter from king Seleukos IV - and therefore provides evidence of the degree of independence that Seleukeia-in-Pieria had in its interactions with the king. It demonstrates both explicit submission to royal authority, and a limited assertion of civic sovereignty.

In the decree, Seleukeia-in-Pieria makes its submission to royal authority very clear. The decree refers to the letter from the king which motivated it as a prostagma

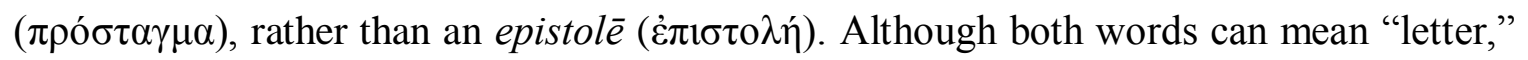
in the language of Hellenistic chanceries, epistole was used for letters in general, including those written to other kings, states and autonomous entities (such as the cities of Western Asia Minor), while prostagma specifically referred to letters sent to officials and other subordinate entities. ${ }^{490}$ Regardless of whom he was addressing, the king usually referred to his own letters as epistolai, ${ }^{491}$ but for a recipient to use the term prostagma, as the Seleukeia-in-Pieria decree does, was to explicitly acknowledge an inferior status. ${ }^{492} \mathrm{~A}$ particularly clear example of this distinction comes from an inscription of Laodikeia-inMēdia (modern Nahāvand), concerning the establishment of a cult for Queen Laodikē. In that, King Antiochos III wrote a letter to an official, which he expressly refers to as an epistolē. When, however, the official passed that letter on to Laodikeia-in-Mēdia he said,

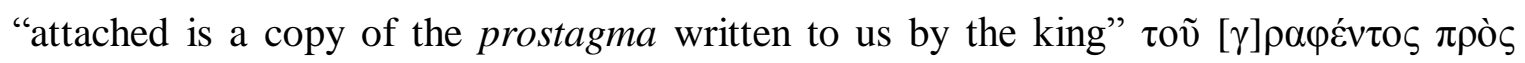

\footnotetext{
${ }^{486} \mathrm{Cf}$. the importance of the theoric fund in classical Athens.

${ }^{487}$ Hansen (2006) 118ff.

${ }^{488}$ Sosin (2005) 139.

489 The degree to which it actually was autonomous depends on one's interpretation of the office of epistatēs (to be discussed below, page 89ff.).

${ }^{490}$ Bikerman (1938) 145; Holleaux (1933) 14; Cotton \& Wörrle (2007) 195; Ma (1999) 107.

${ }^{491}$ e.g. Hefzibah 1.34

492 Cotton \& Wörrle (2007) 195; Ma (1999) 104.
} 


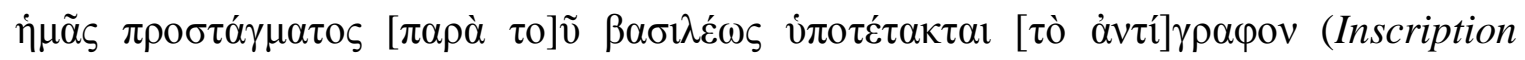
d'Iran, l.2-5). Laodikeia-in-Mēdia simply inscribed the order without even passing a decree, demonstrating its lack of choice in the matter. No doubt many of the decrees of cities in Asia Minor were also issued in response to royal letters, but as the poleis there went out of their way to disguise royal influence, they generally did not include letters from the king except to keep a record of royal benefactions (useful should an official or later king attempt to ignore or rescind the gift). The poleis in Asia Minor always refer to royal letters as epistolai, and they very rarely acknowledge them as a motivating factor in civic decision-making. Thus, scholars such as Capdetrey have interpreted IGLS 3.2.1183, in which the royal letter is included on the inscription and referred to as a prostagma as representing "the integration of Seleukeia-in-Pieria into the Seleukid power structure and the total submission of the subject cities. ${ }^{493}$

Further evidence of Seleukeia-in-Pieria's subjugation might be seen in the king's letter, which proclaims:

Because Aristolochos of our honoured friends furnished the needs of our father, brother, and ourselves with total goodwill, and in most fraught times has eagerly demonstrated his devotion to our affairs, and in other respects we consider him worthy of the goodwill which he embodies and we have honoured him with a bronze statue...

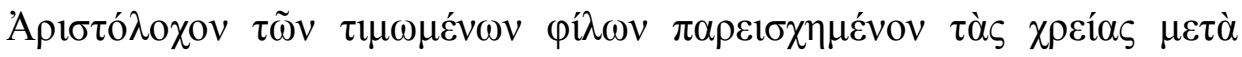

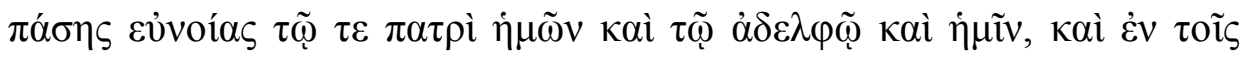

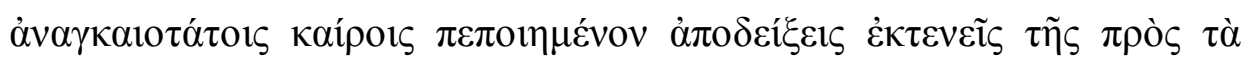

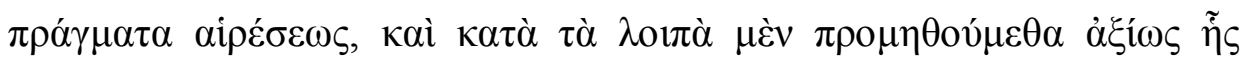

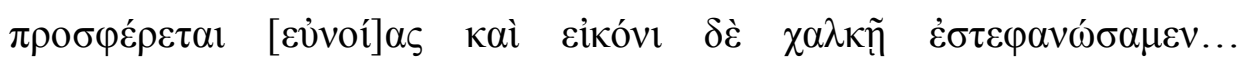

(IGLS 3.2.1183 l.31-37)

All of these reasons for honouring Aristolochos are related to his service to the Seleukid king and dynasty. The letter is not phrased as a recommendation to the city - there is no indication that Seleukeia-in-Pieria has any option other than obedience. The king's perspective was clearly that the city had no choice. ${ }^{494}$

\footnotetext{
${ }^{493}$ Capdetrey (2007) 217: «l'intégration de Séleucie de Piérie à la structure de pouvoir séleucide et la totale soumission des cités sujettes.»

494 e.g. Holleaux (1933) 15: "it is clear that the decree has been brought about by command and was only passed by vote in order to satisfy the wishes more or less expressly declared by the king in his letter" «il est
} 
As the main decree shows, the city did obey the king's command and it acknowledged that that was what it had down by using the word prostagma in the preamble. However, the preamble's justification of the honours voted to Aristolochos does not leave it at that. Instead, it claims that Aristolochos deserved honour because:

in many cases [he] has both been of advantage to the city and has voluntarily aided the citizens publicly and individuals privately, and, moreover, Konōn, Zēthos, Androklēs, [and] Artemidōros, the ambassadors who were sent to the King and have returned, reported how much trouble he went to with the King regarding the matters for which they were sent...

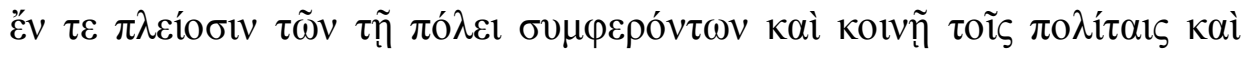

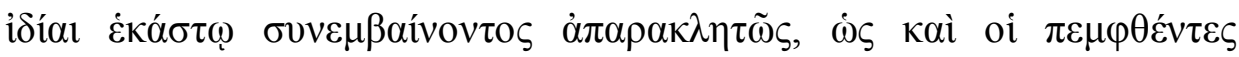

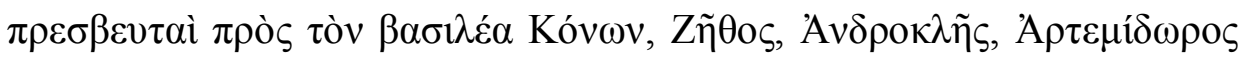

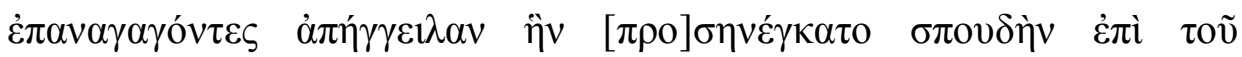

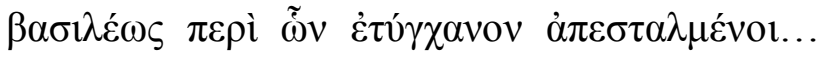

(IGLS 3.2.1183 l.7-14)

The central idea is that Aristolochos was worthy of honour, not for services to the king which are left unmentioned, but for his services to the city, both general and specific. Despite the concession that honouring Aristolochos is the king's command, the decree expends much more effort establishing that it is also in the city's interest. The trend continues in the hortatory section, where it is said that Seleukeia-in-Pieria honours people:

in order that others also (learning what comes from our city to those who endeavour to love goodness) might become imitators of [him in] aiding the citizens...

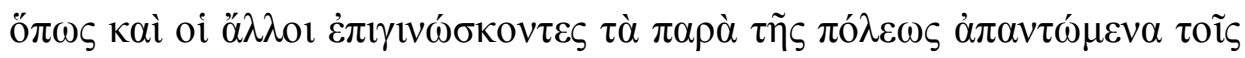

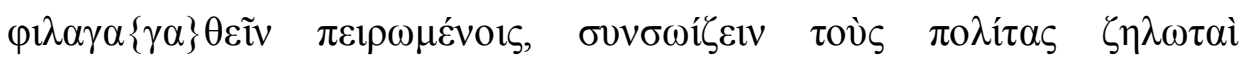
$\gamma \mathrm{ivó} \mu \varepsilon v 01 . .$.

(IGLS 3.2.1183 l.16-19)

manifeste que le décret a été rendu par ordre et n'a été voté qu'afin de satisfaire aux volontés plus ou moins expressément signifiées par le roi dans son écrit» 
Though hortatory sections are usually extremely formulaic, this hortatory still demonstrates a focus on the reasons why the city chooses to honour Aristolochos. The decree never claims to honour him "for his services to the king" or "so that others also might seek to emulate him by rendering service to the king." Thus Seleukeia-in-Pieria here claims independent agency, just as a city of Western Asia Minor might. ${ }^{495}$ When it comes to the actual action, the city goes even further:

It is resolved by the people to commend Aristolochos for such conduct and to grant our citizenship to him.

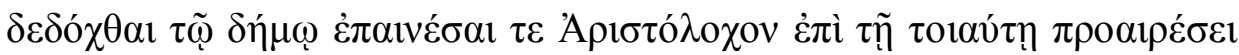

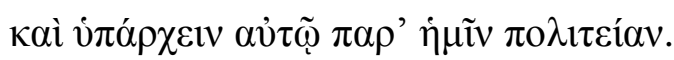

(IGLS 3.2.1183 l.20-22)

The decision to grant Aristolochos citizenship is presented as deriving from the city. It is not mentioned in the extant portion king's letter and the verb vं $\pi \dot{\alpha} \rho \chi \varepsilon 1 v$ is typically used in Hellenistic inscriptions to indicate that something granted by the authority of the issuer of the decree. ${ }^{496}$ This implication is strengthened by the contrast with the dedication of the statue, mentioned immediately thereafter, and explicitly identified as a grant of the king:

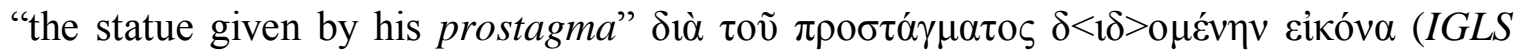
3.2.1183 l.22-23). The decree then finishes by discussing the logistics of enrolling Aristolochos as a citizen. Thus all focus is on the city as an independent actor, which suggests a desire on the city's part to be such an actor. The decree as a whole suggests a process of negotiation between royal and civic wills, like the decrees of the poleis of Western Asia Minor, but with the balance falling far more in the king's favour than in Asia Minor. The polis' presentation of itself as an autonomous actor would be pleasing to all parties: Aristolochos received honours from two groups instead of one, the city was

\footnotetext{
${ }^{495}$ Note the parallel phrasing of OGIS 339 l.90 from Sestos: "that they might become emulators of his

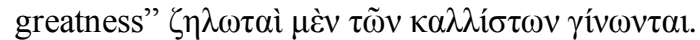

${ }_{496}$ e.g. OGIS 223 l.28, from Seleukos II to Erythrai “... also will be granted to you and whatever other

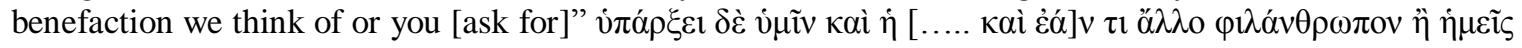

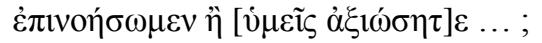

$R C 25$ l.36-39 from Ziaêlas of Bithynia to Kōs "to consider those who dock at the places which we rule in

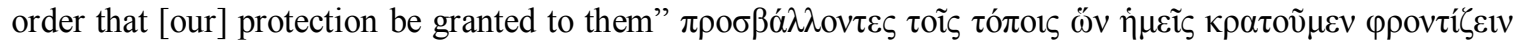

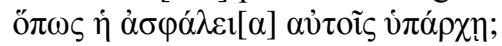

RC 26 l.8-12, from (probably) Seleukos II to Kōs, "they asked that asylia be granted from us to those

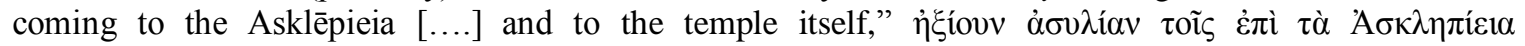

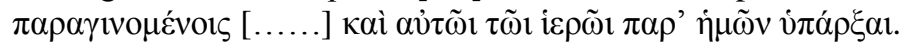

This usage is independent of the meanings "pre-existing" and "friendship/relationship," which only occur in Hellenistic inscriptions when the verb is an appositive participle and a substantive participle respectively.
} 
able to claim agency, and, if the king ever had occasion to hear the decree, he would be gratified to hear that the wishes and interests of the polis coincided with his own.

\section{Officials and Institutions within the Polis}

The decrees and the civic coins both suggest a desire to act as free agents under the kings. They also provide insight into the political structure of the poleis. IGLS 3.2.1183 and IGLS 4.1261 both mention an epistatès, who acted as interface between king and city; a group of magistrates, the archons; and a small Assembly. These similarities make it fairly likely that both decrees represent a similar constitutional system. It is not surprising that two cities of the Syrian Tetrapolis should show constitutional similarities given that they were founded on the same physical model at the same time. ${ }^{497}$ The similarities between their constitutional structures presumably date back to their initial foundation. ${ }^{498}$ Supplemented by other, shorter inscriptions and incidental references in the literary evidence, it is possible to make some generalisations about the internal political structures of the Seleukid foundations, the way those structures functioned, and the degree to which they were dependent on the king and his officials.

\section{The Epistatēs}

For the purpose of understanding the relationship between king and polis, the epistatess and archons are the most important officials. The epistatēs has often been understood as a royal governor and commander of the local royal garrison. ${ }^{499}$ This is an inaccurate characterisation. ${ }^{500}$ The epistatēs did not generally have command of military forces and his position was more complex than 'governor' implies. He was, at once, both the royal representative appointed over the polis and a magistrate of the polis exercising power according to the laws.

The epistatai are prominent in the two decrees discussed above (IGLS 3.2.1183 and IGLS 4.1261). The epistatēs of Seleukeia-in-Pieria, Theophilos, was an addressee of the Seleukos IV's letter, alongside the archons of the city. With them, he drafted and officially proposed the decree. The Laodikeia-by-the-Sea decree was also proposed by

\footnotetext{
497 See discussion of insulae above (page $42 \& 47$ ).

${ }^{498}$ Rostovtzeff (1941) 1.487.

${ }^{499}$ E.g. Holleaux (1933) 27; McDowell (1972) 152; Mørkholm (1966) 110ff.; Musti (1966) 186; Roueché \& Sherwin-White (1985) 31; Sherwin-White \& Kuhrt (1993) 165; Shipley (2000) 75; Walbank (1984) 72; On the lack of criticism in the scholarly literature on this point: Haztopoulos (1996) 377.

${ }^{500}$ Grainger (1990a) 62; Hammond (1999) 374 sees the epistatēs as more of a 'royal agent', which seems more accurate, as will be discussed below.
} 
the city's epistatēs, Asklēpiadēs, along with the archons. Epistatai are also attested at Seleukeia-on-the-Tigris, ${ }^{501}$ Doura-Eurōpos, ${ }^{502}$ and Jerusalem from the time of Antiochos IV. ${ }^{503}$ Recipients of royal letters at other cities also appear to be epistatai: the inscription from Laodikeia-in-Mēdia has identical phrasing to IGLS 3.2.1183 and is therefore likely addressed to an epistatês. ${ }^{504}$ The pahatu at Babylon and the šaknu at Uruk have been interpreted as epistatai or analogues. ${ }^{505}$ In most cases, however, the identification is uncertain, as the Seleukid kings rarely employed the titles of their subordinates in correspondence. The office seems to have been associated with the new foundations, for there is no evidence of epistatai in the old cities of Asia Minor. ${ }^{506}$

It seems highly likely that the Seleukid epistatai derive from the homonymous office in the cities of coastal Macedon in the fourth century, itself a continuation of an office in the Chalkidian League. ${ }^{507}$ Hatzopoulos' definitive study of Macedonian institutions concluded that in fourth-century Macedon, these epistatai were eponymous annual civic magistrates, citizens of the city in question, whose role was to chair a board of magistrates (usually called archons, like the magistrates at Seleukeia-in-Pieria and Laodikeia-by-the-Sea) and to receive messages from the king and others on behalf of that board and the city. ${ }^{508}$ In Hatzopoulos' schema, then, the epistatēs represents a city with substantial self-rule.

Hatzopoulos denies that the Macedonian epistatai were royal officials, on account of the number of cities that had them and the annual nature of the office. The nature of Macedonian and Hellenistic officialdom means that the king simply cannot have had enough officials within his court: in the Hellenistic system, royal officials were presented

\footnotetext{
${ }^{501}$ Polyb. 5.48.12.

${ }^{502}$ P.Dura \#16B; \#17A; \#17C; \#25: These are all of Parthian date, but presumably reflect the continuation and development of an earlier office: Rostovtzeff (1941) 856.

${ }^{503}$ II Macc. 5.22.

${ }^{504}$ Inscription d'Iran l.1.

${ }^{505}$ Babylon: Hammond (1999) 374. The pahatu is always associated with the politai of Babylon and one Babylonian chronicle refers to an official who is apparently the epistatēs of Seleukeia-on-the-Tigris as a pahatu: Boiy (2004) 206. It therefore seems highly likely that he was the epistatês of the Greek community within Babylon.

Uruk: Walbank (1957, 1967, 1979) 1. 579; Doty (1977) 24, is more cautious. Even if the šaknu were the analogue of an epistatēs from the king's perspective, Uruk was not organised on the polis model and its internal political structure remained largely as it was before the Macedonian conquest: Linssen (2004) 168, so the šaknu cannot be used as evidence for the internal role of the epistatēs in the Seleukid poleis.

${ }^{506}$ Bikerman (1938) 145; Cohen (1978) 81. There were epistatai at Miletos, but they formed a board, predate the Hellenistic period, and are not the same magistracy: Nawotka (1999) 104. They are also attested in Asia Minor as sanctuary managers: Aperghis (2004) 284.

${ }^{507}$ Hatzopoulos (1996) 156-166 \& 371-427.

${ }^{508}$ Hatzopoulos (1996) 156-166 \& 371-427.
} 
as royal friends or philoi ( shameful implication that they were servants. ${ }^{509}$ Since royal officials derived their authority from the strength of their personal friendship with the king, the number of officials in the kingdom was limited by the number of personal friendships which the king could possibly have. In light of Hatzopoulos' argument, Bikerman's interpretation of the Seleukid epistatai as citizens of their poleis seems reasonable. ${ }^{510}$ But Hatzopoulos' point need not hold for the Seleukid epistatai. The Seleukid kings had a far larger pool of courtiers than the Tēmenids and, increasingly, the idea that these courtiers were just friends helping the king out was more notional than actual. ${ }^{511}$ Moreover, whereas the Macedonian epistatai had to be annual positions because their names were used as the name for each civic year, the Seleukid cities used the Seleukid royal dating system instead and could therefore have the same epistatēs indefinitely. ${ }^{512}$ The trend was definitely towards long term tenures: by AD 51, the epistatēs at Doura-Eurōpos was a hereditary dynast. ${ }^{513}$ When the office became hereditary is unclear, but Doura-Eurōpan epistatai's frequent use of the name Seleukos and maintenance of the Seleukid cults strongly suggests that their family traced their roots to the Seleukid period. It would not be surprising if the Seleukid epistatai were basically hereditary in general; several important Seleukid royal governorships were de facto hereditary. ${ }^{514}$ Therefore, it seems likely that the Seleukid epistatai, unlike their earlier Macedonian forebears, were in charge of their poleis for long periods of time, potentially inheriting the office for many generations.

The Seleukid kings consistently maintain a distinction between the epistatēs and the cities' magistrates, marking the epistatēs as separate from the city. ${ }^{515}$ For example, the salutation of Seleukos IV's letter to Seleukeia-in-Pieria in IGLS 3.2.1183, firmly separates the epistatès, Theophilos, from his city and magistrates, by both a kaì and an intervening genitive:

\footnotetext{
${ }^{509}$ Herman (1982) $119 \mathrm{ff}$.

${ }^{510}$ Bikerman (1938) 163.

${ }^{511}$ Herman (1982) $124 \mathrm{f}$.

512 Bikerman (1938) 145. The royal dating system can be seen in use in IGLS 3.2.1183 l.27; IGLS 4.1261 l.1; OGIS 257 l.18.

513 Johnson (1932) 17.

514 The best attested example is the line of Thrasead governors in Cilicia (later promoted given control of all Koilē-Syria): Jones \& Habicht (1989) 342.

${ }^{515}$ Hammond (1999) 374, e.g. IGLS 3.2.1186.
} 
King Seleukos to Theophilos and to the archons and city of the Seleukeians-in-Pieria, greetings.

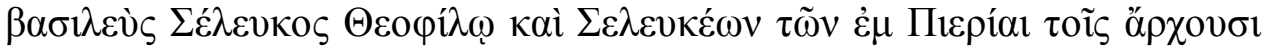

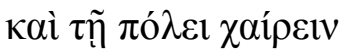

(IGLS 3.2.1183 l.28-29)

Referring to an individual at all is unusual - letters to poleis in Asia Minor were

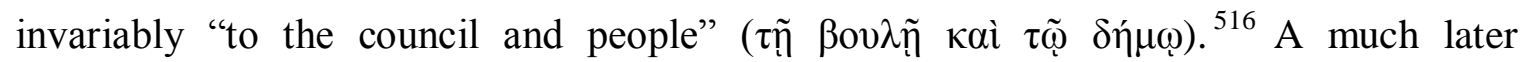
inscription, which purports to free Seleukeia-in-Pieria and will be discussed in more detail below, follows this format, implying that the kings viewed the office as incompatible with civic freedom. Further, the king's letter refers to Theophilos without a title, the usual way for the king to refer to his officials; using titles would imply shameful servitude and an impersonal relationship, not the friendship which was supposed to exist between a king and his philoi. As a result, kings addressed their officials only by name and terms of endearment. ${ }^{517}$ There is a strong implication, then, that Seleukos viewed Theophilos as a royal philos, which is not necessarily mutually exlusive with Theophilos also being viewed by the polis as a civic magistrate.

There are three parallel cases which suggest that the Seleukid kings viewed civic leaders as royally appointed philoi. These cases also suggest, however, that the kings selected these leaders from among the inhabitants of the polis in question. The first of

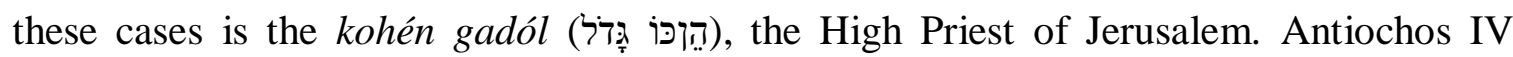
appointed a series of individuals to this office, ${ }^{518}$ all drawn from the group eligible as (alleged) descendents of Aaron, brother of Moses. When Antiochos mentions one of his appointees, Menelaos, in a letter to Jerusalem, he is untitled, in the manner of a royal friend. ${ }^{519}$ However, it is unclear how far the unique situation at Jerusalem can be generalised. The second example comes from the Astronomical Diaries, which explicitly mention that the pahatu of Babylon was appointed from among the pulite (i.e. politai). ${ }^{520}$ If the pahatu was the epistatēs of the Greek/Hellenised community of Babylon, then this

\footnotetext{
${ }^{516}$ e.g. OGIS 214; 223; 227; 231; 232.

517 e.g.; Joseph.AJ 12.148 to Zeuxis (in charge of Asia Minor); Hefzibah letters to stratēgos Ptolemaios and other local officials; Inscription d'Iran to Menedēmos (stratēgos?); OGIS 221 to Meleagros (stratēgos of the Hellespontine satrapy).

518 e.g. Joseph. AJ 12.237-240.

${ }^{519}$ II Macc. 11.29 \& 11.32. Habicht, argues persuasively that the letter is genuine, "Royal Documents in Maccabees II," 12.

${ }^{520} \mathrm{AD}-129 \mathrm{~A}_{2}$ Obv.17,
} 
offers fairly explicit evidence for the epistatēs as an official appointed from the local populace. $^{521}$ The pahatu is repeatedly mentioned in the diaries as the person to whom messages from the king were read, ${ }^{522}$ so this evidence might also support the idea that the epistatēs was a philos from the king's point of view. Again, though, it is difficult to know whether it is possible to generalise from Babylon. The third piece of evidence is OGIS 254, an inscription of Mesopotamian provenance, in which the Epistatēs Dēmokratēs is honoured by the (unidentified) city in which he serves. ${ }^{523}$ Dēmokratēs is called the son of Byttakos, an exceptionally rare name which is otherwise only attested in Polybios, ${ }^{524}$ as the name of one of Antiochos III's generals during the Fifth Syrian War, Byttakos the Macedonian, who led a contingent of troops from throughout the kingdom and was certainly a royal philos. ${ }^{525}$ His son would have been likely to become one too, so this inscription would be good evidence that the kings appointed philoi as epistatēs. Like the other two examples, there is a slight snag in that the date on the inscription is partially destroyed. Some have argued that the inscription actually dates to the Parthian period (129 BC-AD 228), on the grounds that Dēmokratēs also holds the title of stratēgos, and the combination of that title with epistatès is otherwise attested only at Parthian DouraEurōpos. ${ }^{526}$ But stratēgos is a very common title and the combination of offices could have Seleukid roots or have occurred independently in Dēmokratēs' case. ${ }^{527}$ Thus, though these three items of evidence are individually rather weak, together they make a strong case for the epistatai having been royal philoi. They also suggest that the epistatai tended to be locals, could form part of a dynasty, and could be civic officials from the polis' perspective.

Of the epistatai of the new foundations the only one about whom we have any evidence at all is the aforementioned Theophilos of Seleukeia-in-Pieria and he seems to conform to this pattern insofar as he seems to be addressed as a royal philos, as discussed above. It is possible that he was an inhabitant of the polis before his appointment like Menelaos and the Babylonian pahatu. A Theophilos is honoured for holding games in an inscription of $197 \mathrm{BC}$ as a native of Seleukeia: "Theophilos, son of Diogenēs, the

\footnotetext{
${ }^{521}$ Hammond (1999) 374.

522 e.g. AD -132 B Rev. 23-25, -124 B Rev. 17.

${ }^{523}$ Sherwin-White (1982) 65.

${ }^{524}$ And in inscriptions relating to an Athenian family of the first century BC: Lambert, "Greek Inscriptions on Stone," 507.

${ }_{525}$ Polyb. 5.79.4. Identification derives from Köhler, “Zwei Inschriften aus der Zeit Antiochos’ IV,” 1107.

${ }^{526}$ P.Dura \#16b; \# 17A \& C; \#25 ; Johnson (1932) 17ff.; Rostovtzeff \& Welles (1931) 54.

${ }^{527}$ Rostovtzeff (1941) 856.
} 


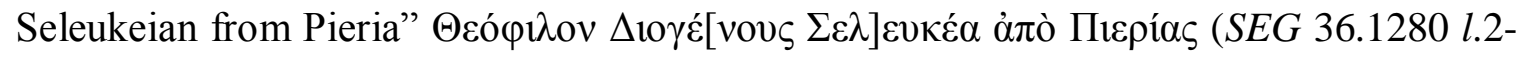

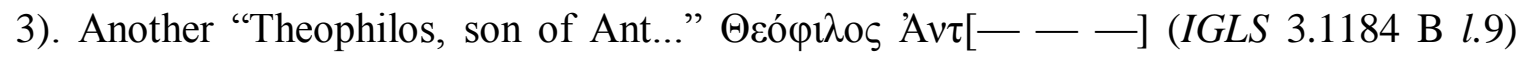
occurs as the polis' annual priest of Apollo in an inscription from the reign of Seleukos III (187-175 BC). Unfortunately, these two examples only serve to underline the fact that Theophilos is a very common name; either of these could have later become Theophilos the Epistatēs, or he could be a third individual. If the office was, as suggested above, a semi-hereditary one, however, the possibility of Theophilos the Epistatēs being a local is increased, however. As we shall see, however, there is a fair amount of evidence supporting the idea that, as in the three cases above, Seleukeia-in-Pieria viewed its epistatēs as in some manner a local magistrate.

\section{Role within the City}

What, then, was the role of the epistatai within the poleis? On this point, Cohen frankly declared, "we do not know what, if any, powers... [they] had." ${ }^{25}$ One reason for this uncertainty is that epistatēs is a vague word. Its literal meaning, "one who is set over," is a concept capable of many meanings. In Classical Athens it was the title of several magistrates, including annual chairmen of various boards, managers of extra-ordinary projects, and the daily president of the prytany. ${ }^{529}$ In all these cases it was a civilian office with limited, constitutional, authority, but the word could also indicate strong commands with an autocratic military flavour. Many authors use it to refer to someone in charge of a body of troops, ${ }^{530}$ it was the title of the rulers of the region of Kommagenē while they were still marcher vassals of the Seleukid king, ${ }^{531}$ Josephos uses the word to translate the title of the Roman Prefects of Syria, ${ }^{532}$ and Diodoros uses it to refer to the royallyappointed dictator of Athens, Dēmētrios of Phalēron. ${ }^{533}$ So the term has a wide range of meanings - from chairman or manager through to master and commander. As a result, the term on its own could be taken to indicate a city with either a great deal of autonomy, or absolutely none. Nevertheless, Cohen's statement is overly pessimistic. It is possible to draw out a limited idea of how epistatai operated in practice from the source material. In

\footnotetext{
${ }^{528}$ Cohen (1978) 81.

${ }^{529}$ Hammond (1999) 370.

${ }^{530}$ e.g. Xen. Anab. 3.11; Arr. Tact. 6.4.

${ }^{531}$ Diod. Sic. 31.19a.1.

${ }^{532}$ Joseph. AJ 16.280 .

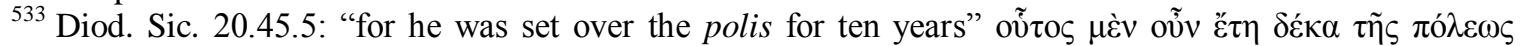

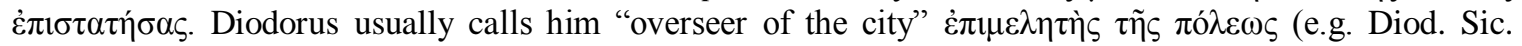

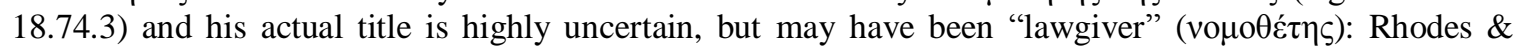
Lewis (1997) 40.
} 
doing so, it is important not to be too legalistic, for neither the epistatēs nor any other Hellenistic official had codified powers - their competencies contracted and expanded as circumstances and personalities allowed. ${ }^{534}$

It does not appear to have been the norm for the epistatēs to hold military duties or the command of any soldiers - as discussed on page 78f., command of the garrison seems to have belonged to separate officials, such as the epi tōn akrophthlakiōn or the akrophylax. ${ }^{535}$ Apparently, there was an intention to keep administrative and military powers separate, which, however, was not necessarily maintained in practice. On the contrary, the Seleukid kings regularly invested as much power as possible in individuals whom they trusted entirely - the viceroys of Asia Minor are an example of this tendency. ${ }^{536}$ In the civic sphere, the multiple offices held by Dēmokratēs of OGIS 254 are evidence for the same practice - not only was he epistatēs and stratēgos, as discussed above, he was also epi tōn akrophthlakiōn (commander of the city's garrison). However separate all these offices might have been in theory, together Dēmokratēs' offices would have given him near absolute power over the city.

But when epistatai did not hold military authority, they were not necessarily very powerful officials. Philippos, epistatēs of Jerusalem, shared authority over the city with a stratēgos appointed over the region, and the Kohén Gadól Menelaos. ${ }^{537}$ It is clear from the subsequent narrative in II Maccabees that the prime movers in Jerusalem were Menelaos and the strategos. Epistates Philippos reappears only to support Menelaos in enforcing Antiochos IV's law against Judaism and later to beg the central government for aid when the Jews rebel. ${ }^{538}$ Philippos is not mentioned in any of the royal letters to Menelaos and the Jews found in II Maccabees at 11.27-33, which are very likely to be genuine. ${ }^{539}$ In such circumstances, the epistatēs' only source of power and authority might be his personal connection with the king as a royal philos. ${ }^{540}$ But that personal connection cannot have been strong in all instances - the king can only have had a strong personal connection with a limited number of people, and there were many cities in the

\footnotetext{
${ }^{534}$ Badian (1968) 198. Cf. Billows (1990) $243 f$.

${ }^{535}$ Polyb. 5.50.10; Walbank (1957, 1967, 1979) 1.579.

536 See page 16.

${ }^{537}$ II Macc. 5.22.

${ }^{538}$ II Macc. 6.11; 8.8.

${ }^{539}$ Habicht (1976) 12.

${ }^{540}$ Even that seems to have been pre-empted in the case of Philippos at Jerusalem, because, as mentioned above, Menelaos the kohén gadól was apparently a royal philos himself.
} 
Seleukid heartland. The kings would have had so-called philoi in a number of cities, many of whom they might have met only once, if ever - Dēmokratēs of OGIS 254, for example, might have been a philoi more on account of his accomplished father, Byttakos, than any personal connections of his own. Thus, the degree to which any given epistatess would have been able to have recourse to a personal relationship with the king might have been very limited. Those with very little personal relationship with the king (i.e. those who could least rely on this as a source of authority) would also have been, by that very fact, the ones whom the king would be least likely to entrust with substitute sources of authority, such as troops. In that case, they had to look for support within the civic sphere to buttress their royal authority.

The civic archons seem to have been that buttress. The king viewed them as entirely civic magistrates, not philoi - insofar as the salutation of the king's letter to Seleukeia-in-Pieria in IGLS 3.1186 separates the epistatês Theophilos from the city, it associates the archons with the city. However, the polis makes very little distinction between the epistatēs and the archons. In both the Seleukeia-in-Pieria decree and that from Laodikeia-by-the-Sea, the epistatess is consistently mentioned before the archons and is the only civic official whose name is recorded - he clearly had primacy. However, he is only depicted acting in unison with the archons. Both decrees were proposed by the

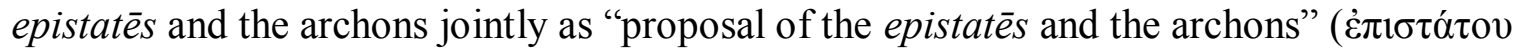

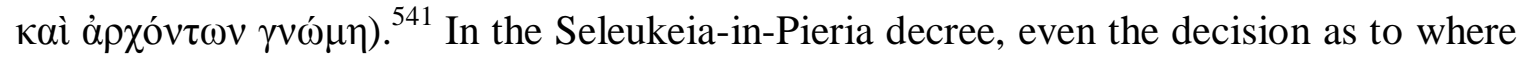
the statue shall go was to be made jointly:

The epistatēs and the archons shall assign a place for the statue given by [the royal] prostagma, in the town hall...

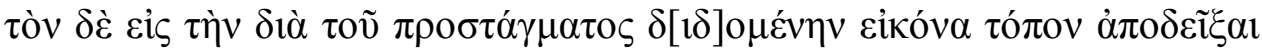

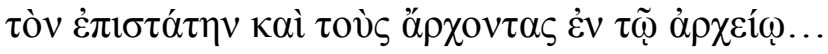

(IGLS 3.2.1183 l.23-25)

Does this close co-operation indicate that the epistatês completely dominated the archons or does it represent a true partnership between them? This probably depended on the specific personalities involved, but the different royal and civic perspectives in IGLS 3.2.1183 (discussed above, pages 85-89) imply that the epistates and the archons were

${ }^{541}$ IGLS 3.2.1183 l.1 \& IGLS 4.1261 l.2. 
genuinely working together - otherwise, whence came the civic perspective? Further, the amount of stress put on demonstrating concord between epistatēs and archons implies that they might not always have agreed in fact.

By working together, the epistatēs and the archons were able to dominate the rest of the polis. Their dominance is suggested by the phrase "proposal of the epistates and

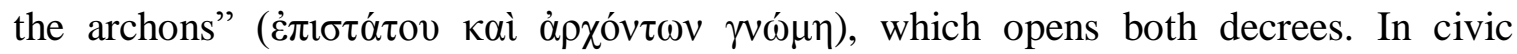
decrees, the word $\gamma v \omega ́ \mu \eta$ indicated the decree's origin as a proposal put to the Assembly, ${ }^{542}$ but it came to be associated particularly with probouleusis, the procedure whereby a matter had to be discussed by the boule, or a section of it, before it could be discussed in the Assembly. ${ }^{543}$ Often, though not inevitably, probouleusis gave the smaller body extensive control over the Assembly - the smaller body would write up a decree and present it to the Assembly, which would be given no opportunity to discuss or amend the proposal, only the bare power to accept or reject it. ${ }^{544}$ The magistrates and epistatess seem to have held this dominance at Seleukeia-in-Pieria, ${ }^{545}$ considering the prominence which Seleukos IV's salutation to the city gives to its archons, rather than to its démos. ${ }^{546}$

The central feature of the office of epistatess, then, with regards to the relationship between king and polis, was that the office was perceived and presented very differently by king and polis. The king acted as if the epistatai were his trusted philoi, but they were often locals of their poleis, which presented them as part of their civic system. Together with the archons, the epistatēs bridged the gap between royal and civic spheres acting as the agent of each to the other. This role as an intermediary made the epistatai important to both parties, and was their avenue to independent power. By the Parthian period they had turned this influence into hereditary rule at Doura-Eurōpos and possibly elsewhere still stressing their close personal link to the Seleukid dynasty. ${ }^{547}$

\footnotetext{
${ }^{542}$ This is the reason why decrees are in indirect speech, hanging off, "the opinion of the epistates and

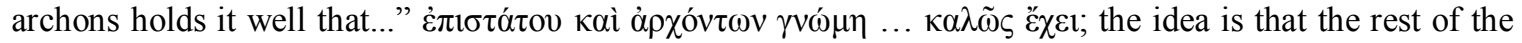
decree reports the words that they spoke to the assembly.

${ }^{543}$ Rhodes \& Lewis (1997) 487.

${ }^{544}$ Rhodes \& Lewis (1997) 488; Ehrenberg (1969) 58.

${ }^{545}$ Cohen (2006) 127.

${ }^{546}$ IGLS 3.1183 l.29.

${ }^{547}$ Johnson (1932) 18ff.
} 


\section{Peliganes and Restrictive Citizenship}

Typically, the final decision-making power ${ }^{548}$ in a polis belonged to some form of assembly of citizens, with a boule administering the polis' day-to-day affairs. These two organs appear to have existed in the new foundations as well, but the archons and epistatès seem to have dominated them. The existence of some sort of Assembly is implied by the citation formula "it has been resolved" ( $\delta \varepsilon \delta \delta$ ¿ $\chi \theta \alpha \mathrm{l}$ ), in IGLS 3.2.1183 and 4.1261. This formula is a standard element of decrees indicating what action is to be taken and under whose authority. ${ }^{549}$ But the two decrees use different words for the body which is responsible for the legislation.

At Laodikeia-by-the-Sea the assembly was called the peliganes $(\pi \varepsilon \lambda \imath \gamma \tilde{\alpha} v \varepsilon \varsigma),{ }^{550}$ an obscure word of Macedonian origin, which is only attested elsewhere in Hēsychios, a fragment of Strabo, and Polybios. The fifth century lexicographer Hēsychios defines peliganes as "The notables - among the Syrians, the councilmen" oi દ̌voo

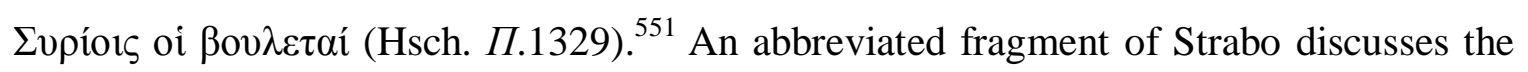
use of the word in Macedon, connecting the term with similar words used for elders among the Thesprōtians and Molossians, and equating them with the gerontes, the members of the Spartan gerousia. ${ }^{552}$ The word is not attested in Macedonian epigraphy and its relationship to Molossian and Thesprōtian terms suggests that it derived from northwest Macedon, which is a poorly attested region even by the standards of Macedon. A far later inscription from AD 193 shows that the tiny communities of this region combined the roles of boule and ekklesia in a single body - perhaps the peliganes were the members of such councils - if having a council at all was not a later development. ${ }^{553}$ Peliganes probably existed, also, at Seleukeia-on-the-Tigris, if Roussel is correct that the

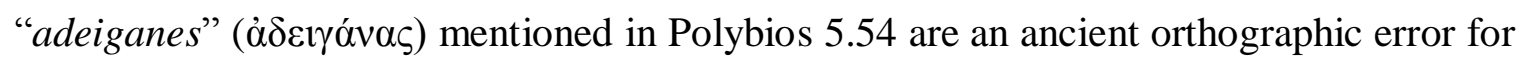
peliganes ${ }^{554}$ as has been widely accepted. ${ }^{555}$ They also seem to occur in a chronicle at Babylon, in which they apparently confront a Parthian prince shortly after the Parthian conquest, alongside Babylon's Greco-Macedonian pulite/politai (Notably, both politai

\footnotetext{
548 Not the same as sovereignty in the sense used in modern political science: Davies (1994) $53 \mathrm{ff}$.

${ }^{549}$ McLean (1972) 223; Rhodes \& Lewis (1997) 5.

${ }^{550}$ IGLS 4.1261 l.21-22.

${ }^{551}$ Roussel (1942-1943) 28ff; followed without acknowledgement by Cohen (1978) 81.

552 Strabo 7 fr.2. Hammond (1972, 1979. 1988) 2.648; Roussel (1942-1943) 28ff.

${ }^{553}$ Hatzopoulos (1996) 79ff. Making reference to earlier, more fragmentary inscriptions, Hatzopoulos speaks frequently of the "remarkable continuity" of institutions in this region.

${ }^{554}$ Roussel (1942-1943) 28ff.

${ }^{555}$ Cohen (1978) 81; Walbank (1957, 1967, 1979) 1.583. Hammond (1993) $53 \mathrm{n} .12$ is alone in dissenting and he does not offer any rationale.
} 
and peliganes are written with the determinative for things connected with the king). ${ }^{556}$ The fact that the term is attested separately in Syria (by Hesychios) and Mesopotamia (by Polybios and the Astronomical Diaries) suggests that the peliganes were among the Macedonian institutions introduced to the Seleukid poleis at the time of their foundations, like the epistatess. The implication, then, is that the Seleukid foundations were founded with and retained assemblies and councils of a Macedonian flavour. ${ }^{557}$

Important as the link with Macedon is, the Seleukid peliganes cannot have been identical to the tiny village councils of Upper Macedon - the massive cities of the Seleukid heartland were an entirely different sort of polis. In IGLS 4.1261, as mentioned above, the peliganes are the ultimate legislative organ, while the epistatēs and archons appear to be the ones performing the role of boule in exercising probouleutic powers over it, implying that the peliganes were the supreme legislative body of the polis. And yet, the evidence from the Babylonian chronicle implies that they were distinct from the

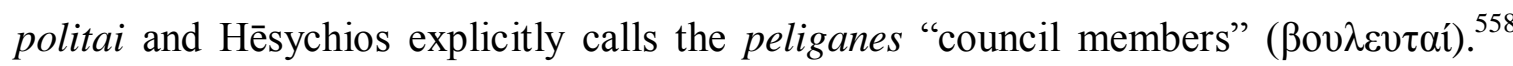
Further, Polybios' narrative at 5.54 implies that the peliganes were relatively few in number. He mentions them in the aftermath of Antiochos III's re-conquest of Seleukeiaon-the-Tigris from the rebel Molōn, when Hermeias was charged with settling matters in Seleukeia-on-the-Tigris. Among many harsh measures, Hermeias attempted to banish the peliganes, presumably for collaborating with Molōn. This was considered too harsh and King Antiochos rescinded the order. The fact that the peliganes were singled out for banishment implies that they bore particular responsibility for Seleukeia-on-the-Tigris' collaboration (i.e. that they held some sort of power) and that they were a small enough group for banishment to be contemplated - they cannot have been a general assembly of all inhabitants of Seleukeia-on-the-Tigris. This would tend to indicate that they were the members of Seleukeia-on-the-Tigris' boule. The importance of Seleukeia's boule as the main institutional organ of the city is demonstrated by the series of Parthian coins from

\footnotetext{
${ }^{556}$ BCHP 18.B3, “"ú pe-li-ga-na-a-n[u...].”

${ }^{557}$ Billows sees an Antigonid precedent: (1990) 304 \& 323, of which Derow is highly critical: (1993) 330.

${ }^{558}$ Musti notes this as "an issue of interest for determining the political structure of Laodikeia, Seleukeia, and those other Seleukid cities in which such an institution may have existed..." "un problema d'interesse per la valutazione della struttura politica di Laodicea come di Seleucia, come delle altre città seleucidiche in cui tale organo sia esistito..." but instead addresses his attention to the implications of the peliganes' survival for the ethnic composition of the new foundations: (1966) 124.
} 
the early first century $\mathrm{AD}$ which bear name and image of an anthropomorphised boule ${ }^{559}$ and also by Tacitus, who says of Seleukeia-on-the-Tigris:

Three hundred are selected as a senate for their power or wisdom, while the people have their own strength...

trecenti opibus aut sapientia delecti ut senatus, sua populo vis...

(Tac. Ann. 6.42)

The implication of the latter half of the sentence is that, while the multitude were politically active, their power was not institutionalised. If Tacitus' three hundred senators are the peliganes, then it was a very small body indeed and institutional power within this very large polis was concentrated in the hands of a very restricted elite (and, presumably, likewise at the other Seleukid foundations). However, the Roman senate was also traditionally composed of three hundred members, ${ }^{560}$ and this, along with the overall narrative of the passage, in which division between senate and people leads the city to fall under the control of a tyrant, suggests that Tacitus' Seleucenses have more to do with Rome than Seleukeia-on-the-Tigris. So Tacitus' senate need not indicate that the peliganes were so few as three hundred. Nevertheless, it does seem likely that the peliganes were a relatively small subset of the city's inhabitants.

It further seems likely that the peliganes were a comparatively small body, because they formed a subset of the citizen body, which itself seems to have been restricted to a small portion of the new foundations' inhabitants. After all, an everincreasing number of the inhabitants in the new foundations would have been immigrant Syriacs, Babylonians, and Jews, who enjoyed only limited enfranchisement in their own politeumata - generally not citizenship. ${ }^{561}$ Greek migrants were probably not citizens automatically, either. The large number of non-citizen inhabitants of these poleis is demonstrated by a reference in the Suda. Praising Antipatros of Late Hellenistic Damascus it mentions his beneficence to "thousands, not only his common citizens, but

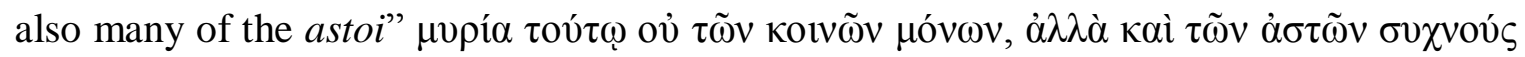
(Suda, A2705), indicating that there were many people who belonged to the settlement

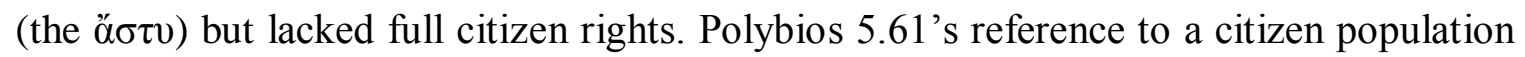

\footnotetext{
${ }^{559}$ SdT 1\#31-32, 2\#542-554 \& 2\#602-625.

${ }^{560}$ Livy 2.1.

${ }^{561}$ Cohen (1978) 86.
} 
of a mere six thousand at Seleukeia-in-Pieria in the time of Antiochos III, roughly the same as the number of initial settlers (as discussed above, pages 43-45) implies that very few immigrants after the initial foundation received citizenship. Likewise, Dio Chrysostomos called on the Tarsians to enrol a dangerously large, similarly

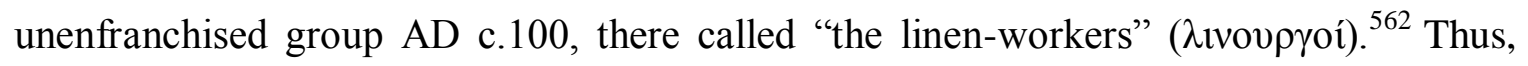
the picture of the internal structure of the new foundations is of a tiered structure. There was a mass of unenfranchised natives and Greeks. Above them were the actual politai, who presumably had rights of some sort, but did not necessarily get any right to make decisions. Above or drawn from the citizens were the peliganes in the supreme decisionmaking body. The peliganes themselves seem to have been dominated by the epistatess and archons. These were communities in which power was ultimately concentrated in the hands of a very small elite.

Another indication of the Seleukid foundations' small elites is the size of their militias. In Classical poleis, service in the militia was correlated with prestige within the polis. This can only have been more so in the Seleukid kingdom, where prestige derived from Macedonian status, ${ }^{563}$ which was theoretically determined by descent, but in practice came to include all those equipped and able to fight in the Macedonian fashion. ${ }^{564}$ The civic militias seem to have been small. During the procession preceding Antiochos IV's great games at Daphnē, "three thousand citizen... horsemen" i $\pi \pi \varepsilon \tilde{\imath} \varsigma$...

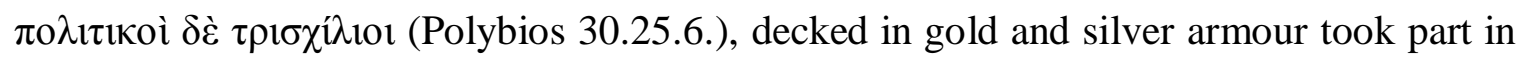
the parade. Their provenance is not indicated: Bikerman takes them as Antiochene alone, while Griffith takes them to represent a wider array of settlements throughout Syria. ${ }^{565}$ In the former case the three thousand horsemen imply a rather large militia, since cavalry was traditionally reserved for the wealthiest members of the polis. ${ }^{566}$ But Griffith's position that the horsement represent the civic cavalry of all the settlements of the Syrian Tetrapolis seems more likely, because limiting participation in the festival at Daphne to the Antiochene militia would have been a slight to the other cities of Syria. ${ }^{567}$ In that case,

\footnotetext{
562 Dio. Chrys. Or. 34.21.

${ }^{563}$ Edson (1958) 164.

${ }^{564}$ Cohen (1978) 31; Musti (1966) 121.

565 Bikerman (1938) 59; Griffith (1935) 146.

${ }^{566}$ However, pasturing horses was less expensive and there was more money available for it in Syria than it had traditionally been in Classical Athens. On the wealth of the Syrian poleis see: Ath. 12.527e-f.

${ }^{567}$ OGIS 253 seems to attest parallel festivals held in Mesopotamia, but Daphnē was the main event and the elites of the Tetrapolis could easily have made it to Daphnē, which is is only half a day's walk from Seleukeia-in-Pieria and not that much more distant from the other Syrian cities.
} 
the foundations' militias look a lot more modest - suggesting that very few people belonged to the upper ranks of the poleis of the Seleukid heartland.

There is a further complication in this discussion of the Seleukid foundations, for,

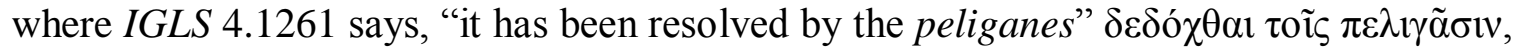
the inscription from Seleukeia-in-Pieria instead uses the far more normal phrase, "it has been resolved by the dèmos" $\delta \varepsilon \delta o ́ \chi \theta \alpha 1 \tau \tilde{\varphi} \delta \eta \dot{\mu} \mu$ (IGLS 3.1183 l.19). This is exactly the same phrase as used in old poleis such as Athens and Miletos and it could be that the phrase refers to the same body as the peliganes at Laodikeia, with a more classically Athenian turn of phrase. However, dèmos generally means the entire citizen body, which the peliganes seem not to have been, so it would be a little strange if the terms were interchangeable. The Seleukeian Assembly could have been a more open one, allowing all citizens like the Athenian and Milēsian Assemblies, which would not be entirely surprising as Athens' forms were influential and the initial colonists at Seleukeia-inPieria probably included a large contingent of the Athenians who had been settled in Syria by Antigonos I. ${ }^{568}$ But, even if Seleukeia-in-Pieria had an Assembly open to all citizens, that Assembly clearly did not wield the power of the Athenian and Milessian Assemblies - as discussed above, the archons and epistatess seem to have used their probouleutic powers to control the polis. Nor would an Assembly open to all citizens have been a very large body, because the number of citizens at Seleukeia-in-Pieria was very small. ${ }^{569}$ Moreover, the sort of Athenians who would settle in Syria in the first place might very well be the sort of Athenians who had left Athens on account of a partiality to a more oligarchic style of government. Thus, even if Seleukeia-in-Pieria's dèmos signifies a different, broader institution than the peliganes, it is unlikely to indicate a popular democracy which institutionally incorporated the masses.

From an analysis of the poleis' internal structure, then, it appears that power was concentrated in the hands of a small elite, itself dominated by the epistatēs and archons. A small elite would have looked to the king for support in controlling the masses - they had nothing to gain and potentially everything to lose from challenging the status quo. The king would have had an investment in maintaining that small elite's position of power. As a tactic for controlling cities, there was nothing new about this - it was

\footnotetext{
${ }^{568}$ Diod. Sic. 20.47.6 \& 21.1.6. Other sources (mostly Antiochene) say the Athenians were moved to Antioch: Malalas 8.201.

${ }^{569}$ Polyb.5.61, though that tally did follow a siege and an extended period as a Ptolemaic exclave. Walbank notes that this is surprisingly small: $(1957,1967,1979) 1.587$.
} 
essentially the same philoligarchic strategy used or attempted in Asia Minor by the Achaimenids and in Mainland Greece by the Spartans in the fifth century, the Antipatrids in the fourth, and the Antigonids in the third. But in the Seleukid foundations, where there was no tradition of popular democracy, ${ }^{570}$ and the masses were divided into many different cultures, it proved a much more successful tactic than it had in mainland Greece.

\section{The End of the Seleukid Kingdom}

The final phase of Seleukid history, from the loss of Mesopotamia to Elymais and Parthia in 140, was marked by the restriction of the kingdom to Syria and increasingly intensive civil war. In the twenty years between 115 and 96, Antiochos VIII and IX each seized Antioch from the other on three different occasions. ${ }^{571}$ After their elimination in 96, five separate individuals laid claim to the Seleukid throne simultaneously. ${ }^{572}$ The final result was the kingdom's complete implosion sometime around $80 \mathrm{BC} .^{573}$ There are two competing schools of thought on how the kings and poleis interacted in this final period. In the older view, advanced by Jones and Rostovtzeff, the poleis used the civil war to extract increasing privileges from rival kings, to the detriment of the kingdom - that is, the self-serving behaviour of the cities was partially responsible for the final collapse of the Seleukid realm. ${ }^{574}$ Jones' position was largely inspired by the narrative of $I$ Maccabees, in which the Hasmonean kings of Judaea use the Seleukid civil war to extract ever more independence from rival Seleukid kings. ${ }^{575}$ Grainger's position is effectively the opposite - he argues that the Seleukid foundations showed conspicuously little desire for independence and that what autonomy they did assume was either illusory or forced upon them as a result of the breakdown of order. ${ }^{576}$

The final period is marked by grants of special status, freedom, and minting rights to the poleis of Syria. OGIS 257 provides evidence of the sort of grants which kings were making in this final period. This inscription preserves two letters of $109 \mathrm{BC}$ from an Antiochos (VIII or IX), ${ }^{577}$ one to both Ptolemaios IX and X and part of one to Seleukeia-

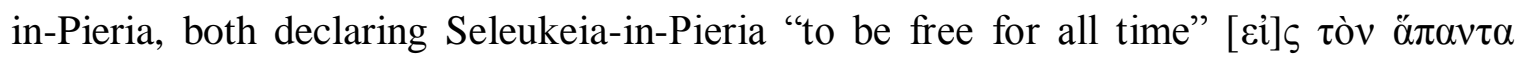

\footnotetext{
${ }^{570}$ Rostovtzeff (1941) 1.156.

${ }^{571}$ Hoover (2007) 284ff.

572 Ibid., $288 \mathrm{ff}$.

573 82 BC: Sherwin-White (1994) 238; Mid-70s BC: Hoover (2007) 290ff..

${ }^{574}$ Jones (1940) 26; Rigsby (1996) 21; Rostovtzeff (1941) 2.843.

${ }^{575} \mathrm{E}$.g the bidding war between Demetrios II and Alexandros II for Jonathan Maccabee's favour: I Mac. 10.

${ }^{576}$ Grainger (1990a) 164. Followed by Rigsby (1996) 28.

${ }^{577}$ Both were reigning in various parts of Syria in 109. Grainger prefers Antiochos VIII: (1990a) 171.
} 


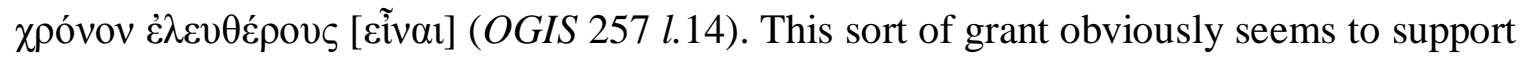
the view that the cities were tearing the kingdom apart. ${ }^{578}$ There are a number of reasons why either Antiochos might have wanted to buy Seleukeia-in-Pieria's loyalty - as a rich port and ideologically important centre Seleukeia would be a valuable prize for either of the kings, but, because they were locked in a civil war and it was unusually well-fortified, neither king was really capable of forcing it to join their camp. Further, by accepting the grant, the Seleukeians would implicitly accept the donor as the legitimate king, rather than one of his rivals. This factor led Ma to characterise these Late Seleukid decrees as "pleas for recognition." $" 579$ There is probably some of that in this decree, but it was not its primary purpose. ${ }^{580}$ If it had been, then one might expect, given that both contenders for the throne were named Antiochos, that the inscription would specify at some point whether the grantor was Antiochos VIII or IX (either by patronymic or by epithet). If the decree is the end result of a bidding war between the two cousins, then it is also fairly restrained - the king does not explicitly release Seleukeia from tax duties, which probably means that he did not, and, therefore, that Seleukeia retained tax obligations towards him - in decrees elsewhere, it was usual to make such a grant explicit, because in the Hellenistic Period being politically free did not mean being tax-free. ${ }^{581}$

That OGIS 257 was found on Cyprus suggests that its primary audience was not Seleukeia-in-Pieria at all, but the Ptolemies. This grant of freedom was an assertion of sovereignty. The letter to the Ptolemies stresses the city's ongoing links to the Seleukid dynasty, saying that the Seleukeians:

... were attached to our father and retained their goodwill [towards hi]m to the end, [and they maintain]ed their affection towards us and showed th[is through many] good deeds and especially in those most [desperate] times...

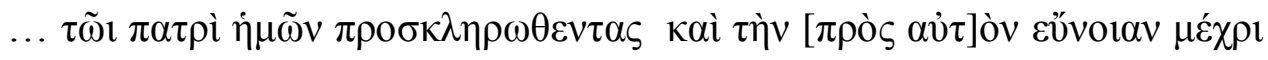

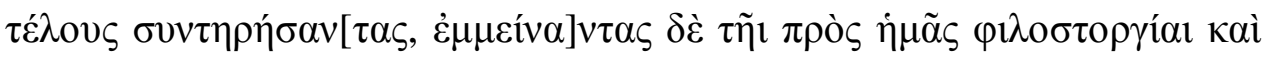

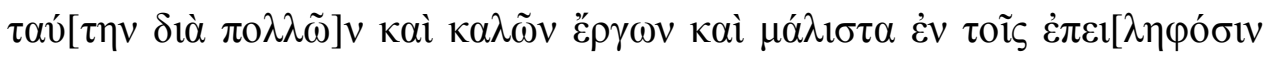

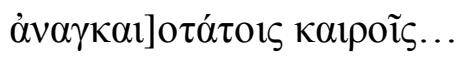

(OGIS 257 l.5-10)

\footnotetext{
${ }^{578}$ Rostovtzeff (1941) 2.846.

${ }^{579} \mathrm{Ma}(2000 \mathrm{~b}) 101$.

${ }^{580}$ Grainger (1990a) 171.

${ }^{581}$ E.g. OGIS 223, or I Mac. 10.25-45.
} 
Later in the inscription, Antiochos strengthens this impression further by calling Seleukeia his "fatherland" $\pi \alpha \tau \rho i ́ \delta \alpha$ (OGIS 257 l.16.). The assertion of these links is particularly significant because Seleukeia-in-Pieria had been ruled by the Ptolemies from 246-219. Thus, Ptolemaios IX actually had a claim to the place as his dynasty's spearwon land, ${ }^{582}$ and the middle of a "most desperate" civil war in Syria would have been an opportune time to act on that claim. Therefore, Seleukeia-in-Pieria might not be the primary audience of the grant in OGIS 257. Other cities that were less vulnerable received fewer gifts and show fewer signs of autonomy. Antioch only began to mint its own silver coins in $92 / 91,{ }^{583}$ a step which Downey interprets as a royal concession, ${ }^{584}$ and as there were four rival Seleukid pretenders in that year, ${ }^{585}$ it is certainly plausible that one of them granted Antioch coining rights in exchange for support or funding. Alternatively, the mintmaster at Antioch may have decided that minting coins in the name of the polis was easier than trying to pick a winner from the four pretenders. Thus, the same phenomenon can be interpreted as the polis seizing power or reluctantly assuming it.

\section{Increased Military Reliance}

There is some evidence that the cities were increasingly asserting themselves against the kings. I Maccabees 11.45 records the earliest instance of mass-action by the people of a polis of the Seleukid heartland. According to the passage, King Dēmētrios II faced a rebellion from the multitude of Antioch and was only saved by the intervention of the Jews. The focus of the passage is clearly on the military strength of the Jews and, as a result, the passage, without doubt, exaggerates the number of Antiochene rebels (who, exactly, was counting them?) and perhaps also the seriousness of the revolt, while offering little context, except that Dēmētrios had replaced his troops with mercenaries and that Tryphōn's revolt was ongoing. ${ }^{586}$ If there is a causal relationship between the dismissal of the soldiers by Dēmētrios and the Antiochenes' revolt against him, then the dismissed soldiers might have been locals. It does seem that the Syrian cities provided

\footnotetext{
${ }^{582}$ Hellenistic kings regularly employed such claims. In Polyb. 18.51.4, for example, Antiochos III asserts his ownership of Thrace based on Seleukos I's supposed conquest of the region in 281 BC. It seems that spear-won land remained spear-won even once lost to the spears of others.

${ }^{583}$ Hoover (2007) 289f.

${ }^{584}$ Downey (1961) 134.

585 Antiochos X Eusebēs, Antiochos XI Epiphanēs, Dēmētrios III Eukairos, and Philippos I Philadelphos. The extreme disorder left ancient and modern historians extremely uncertain as to which of these were in charge of Antioch in that year: Hoover (2007) 290.

${ }^{586}$ I Mac. 11.38-44.
} 
large numbers of troops to the king in the final years of the Seleukid kingdom. For example, when Antiochos IX died in battle in 96, Diodoros claims that:

Three hundred thousand had died, including those who had gone along outside of the battle-array [i.e. as camp followers], such that no house could be found without a part in the misfortune.

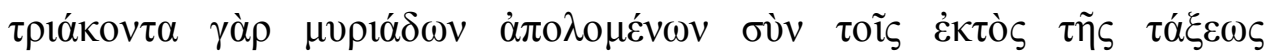

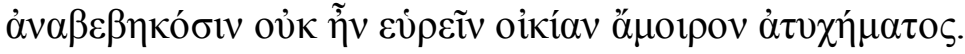

(Diod. Sic. 34/35.17)

The number of dead must be very greatly exaggerated, but there is no reason to dismiss the idea that the city provided a great deal of the royal troops. More Antiochene soldiers were taken as prisoners of war in 95 when Dēmētrios III was defeated by the Parthians. ${ }^{587}$ Another example is found in I Mac. 10.71, when Apollōnios the governor of Koilē-Syria is campaigning against Jonathan Maccabee for Dēmētrios II, he boasts, "the force[s] of

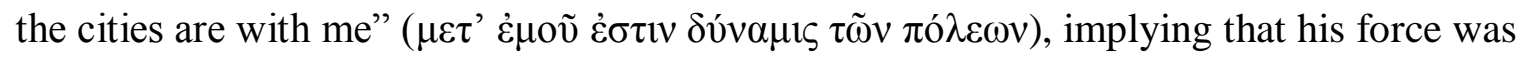
mainly or entirely recruited from the Syrian cities.

This contrasts strongly with the Seleukid army in earlier periods. Polybios' outline of Antiochos III's army during the Fourth Syrian War (219-217) is a good example of this earlier army. ${ }^{588}$ Out of a total of 62,000 infantry and 6,000 cavalry, about half - the "10,000 men, armed in the Macedonian fashion, called from all parts of the

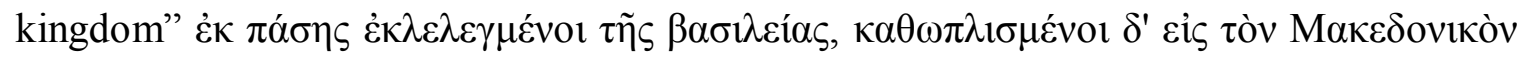
$\tau \rho o ́ \pi$ ov, ớ$v \delta \rho \varepsilon \varsigma \mu$ ṕpır (Polyb. 5.79.4.), and the 20,000 mass of the phalanx were probably drawn in whole or in part from the foundations of the Seleukid heartland. The cavalry are not provenanced - but the cavalry at the festival at Daphnē in 166 consisted of both Mēdian and citizen horsemen. ${ }^{589}$ There is no reason to think that the source of the cavalry in Antiochos III's army was different. Antiochos III, then, could wage a perfectly good war without the Syrian and Mesopotamian cities. But, once Asia Minor (189 BC), Iran and Mesopotamia (139? BC) had been lost, the kings were forced to rely more heavily on their Syrian cities for troops. So the royal polis policy became increasingly conciliatory, and the poleis increasingly assertive, because the kings needed the poleis

\footnotetext{
${ }^{587}$ Joseph. AJ 13.385.

588 The numbers are "beyond dispute," Bar-Kochva (1976) 8.

${ }^{589}$ Polyb. 30.25.6. On the Festival at Daphnē as a reliable guide to the Seleukid army: Paltiel (1979) 32.
} 
more. But the poleis were still negotiating their status under the Seleukid king as before, not trying to free themselves from him.

\section{Tigranēs the Seleukid King}

The way in which the Syrian and Mesopotamian poleis reacted to the final collapse of the Seleukid dynasty indicates that they remained interested in maintaining the status quo, not in obtaining full independence. The civil war in Syria becomes extremely difficult to follow after 95 BC, as Syria grows ever more fragmented between ever more pretenders, but it is clear that Tigranēs the Great of Armenia (95-55 BC) gained control of the region sometime around 80 BC. ${ }^{590}$ Justin, summarising the account of Pompeius Trogus for whom these events would have been within living memory, records:

There was mutual hatred between the brothers and then their sons continued the hostilities of their parents, until the kings and kingdom of Syria were consumed by unquenchable war. So the people sought outside aid and began to investigate foreign kings for themselves. And so, although some proposed the Pontic Mithridates [VI Eupatōr] and others Ptolomeus [IX] of Egypt, in the end everyone agreed on Tigranes, King of Armenia, because Mithridates was entangled in war with the Romans and Ptolemeus had always been an enemy to Syria. Moreover, in addition to his personal power, [Tigranes] had both friendship with Parthia and a marriage alliance with Mithridates. So he was called to the kingdom of Syria and ruled over a peaceful kingdom for 17 years...

Mutuis fratrum odiis et mox filiis inimicitiis parentum succedentibus cum inexpiabili bello et reges et regnum Syriae consumptum esset, ad externa populus auxilia concurrit peregrinosque sibi reges circumspicere coepit. Itaque cum pars Mithridatem Ponticum, pars Ptolomeum ab Aegypto arcessendum censeret, occurreretque quod et Mithridates inplicitus bello Romano esset, Ptolomeus quoque hostis semper fuisset Syriae, omnes in Tigranen, regem Armeniae, consensere, instructum praeter domesticas vires et Parthica societate et Mithridatis adfinitate. Igitur accitus in regnum Syriae per $X$ et VII annos tranquillissimo regno potitus est... (Just.Epit. 40.1)

${ }^{590} 82$ BC: Sherwin-White (1994) 238; Mid-70s BC: Hoover (2007) 290ff.. 
So, once existence free from the Seleukid yoke was achieved, the Syrian poleis reacted by searching for a new overlord. ${ }^{591}$ If the Syrian poleis desired and pursued full independence like the poleis of Western Asia Minor, they would not have brought in a new king. On the contrary, it suggests that they viewed existence under the Seleukid royal aegis as normative and desirable. The candidates were all affiliated with the Seleukid line: Ptolemaios IX was a cousin of the Seleukids and also the brother and exhusband of Kleopatra Selēnē, who had become a symbol of legitimacy, married in turn to Antiochos VIII, IX, and X; ${ }^{592}$ Mithridatēs VI was a maternal grandson of Antiochos IV ${ }^{593}$ Tigranēs is not known to have had a genealogical link to the Seleukid dynasty, except as Mithridatēs VI's son-in-law (a point which Justin specifically draws attention to). However, Tigranēs' family tree is very uncertain and it is therefore possible that he was also a Seleukid by descent ${ }^{594}$ - perhaps via the daughter of Antiochos III who was married to Xerxēs of Sōphēnē. ${ }^{595}$ Not only were the poleis seeking a king, they were specifically seeking a Seleukid king.

The tenor of Justin's account is contradicted by the most extended account of Tigranēs' rule, Plutarch's Life of Lucullus which depicts him as a stereotypical Oriental tyrant and enemy of the Seleukid dynasty, whose subjects want rid of him. This characterisation cannot be taken as accurate. ${ }^{596}$ Plutarch's Tigranēs is introduced thus:

Over Armenia sits Tigranēs, King of Kings, possessing forces with which he deprives the Parthians of Asia, carries the Greek poleis away to Mēdia, rules over Syria and Palestine, slaughters the Seleukid kings and takes their daughters and wives inland.

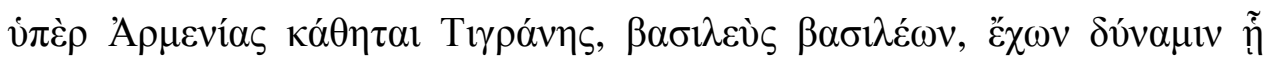

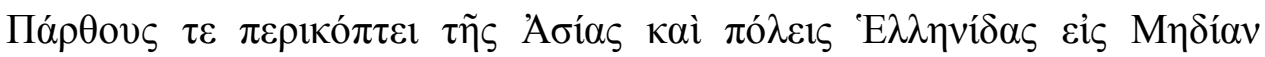

\footnotetext{
${ }^{591}$ Downey argues that this invitation was mostly motivated by the native Syriacs, with many of the Greeks working for independence: (1961) 137. However, populus probably reflects $\delta \tilde{\eta} \mu \circ \varsigma$ and the context appears to be a debate in the Assembly or Council, all institutions which were largely restricted to elite Greeks (see page 98-103 above).

592 Kleopatra apparently maintained a claim on behalf of her son (subsequently a Roman client king, who reigned as Antiochos XIII between 69 and 64), since Tigranēs besieged her in Ptolemais-Akē (an obvious stronghold for a Ptolemaic princess) some time in the reign of Alexandra Salōmē of Judaea (76-67 BC): Josephos AJ. 13.419-420, and she visited Rome to press her sons' claim to the Seleukid throne in the late 70s: Cic.Verr.2.4.61; Downey (1951) 146.

${ }^{593}$ Ogden (1999) 143.

${ }^{594}$ Lang (1970) 130.

${ }^{595}$ Polyb.8.23.

${ }^{596}$ Lang (1970) 136; Redgate (1998) 75.
} 


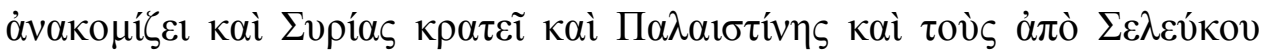

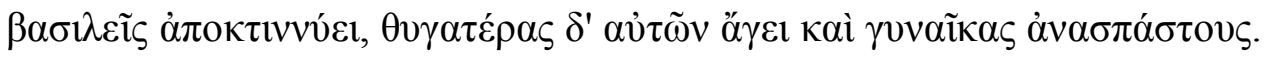

(Plut. Luc. 14.6)

Tellingly, this is part of a speech of Lucullus, Tigranēs' eventual conqueror. Lucullus' characterisation of Tigranēs is upheld throughout the rest of Plutarch's narrative. ${ }^{597}$ Throughout the Life, Tigranēs is presented as a case study in the self-destructive tendencies of barbarian tyranny. ${ }^{598}$ His pomposity towards Appius Clodius brings the Roman onslaught upon him, ${ }^{599}$ his savagery towards his subjects prevents him from being properly informed and encourages his subjects to betray him, ${ }^{600}$ and his inability to control his passions or to distinguish friends from flatterers leads him to defeat. ${ }^{601}$ Ultimately, Tigranēs is saved only by dissension among the Romans. ${ }^{602}$ Depicting Tigranēs thus helps establish parallelism between Lucullus and Kimōn, whose war against Xerxēs, the Oriental tyrant par excellence, was similarly interrupted by dissension among the Greeks. ${ }^{603}$ Plutarch appears more concerned with making moral points about barbarian despotism and the proper character of a statesman, than with portraying Tigranēs' rule accurately. ${ }^{604}$

The limited contemporary evidence for Tigranēs' rule supports Justin's account, indicating that Tigranēs behaved as a typical Seleukid king in his relations with the Syrian poleis. ${ }^{605} \mathrm{He}$ adopted the common Seleukid epithet "god" ( $\left.\Theta \varepsilon o ́ \varsigma\right)$ for his Syrian coins and restricted the title "king of kings" ( $\beta \alpha \sigma i \lambda \varepsilon v ́ \varsigma \beta \alpha \sigma \lambda \lambda \varepsilon ́ \omega v)$, which had Achaimenid or Parthian connotations, to the coins he issued in Armenia. ${ }^{606}$ Tigranēs' Syrian coinage generally follows Seleukid models very closely, ${ }^{607}$ but his Antiochene issues innovate, by depicting the famous Tyche of Antioch carved by Eutychidēs in the reign of Seleukos I (depicted at left courtesy of wildwinds.com). ${ }^{608}$ This prominent Antiochene civic symbol

\footnotetext{
${ }^{597}$ Swain (1992) 311.

${ }^{598}$ This fits naturally into the philosophy of Plutarch, who generally equates Hellenisation with virtue and coined the derisive term $\varphi$ ı $о \beta \alpha ́ \rho \beta \alpha \rho \circ$ for Herodotos: Duff (1999) 59, 298ff. Mossman (2010) 159.

${ }^{599}$ Plut. Luc. 21.7.

${ }^{600}$ Ibid. 22, 25.1, 29.2.

601 Ibid. 26.

602 Ibid. 34.

${ }^{603}$ On the importance of moral and thematic unity between the pairs in Plutarch's Parallel Lives, see Tatum (2010) $2 \mathrm{ff}$.

${ }^{604}$ Cf. Plut. Alex. 1; Pelling (2011) 102.

${ }^{605}$ Rostovtzeff (1941) 2.856.

${ }^{606}$ Lang (1983) 528; Redgate (1998) 75.

${ }^{607}$ Rostovtzeff (1941) 2.856.

${ }^{608}$ Stansbury-O’Donnell (1994) 55.
} 
had not previously appeared on coinage, but it became closely associated with Tigranēs; he also depicted it on coins issued at his new capital, Tigranokerta. ${ }^{609}$ Thus, Tigranēs identified the Tyche , an expression of polis identity, with himself - allowing it to also be an expression of loyalty to him as king, just as the early Seleukids had with their symbols. In accordance with the practice of Hellenistic kingship, Tigranēs adapted his selfpresentation to accord with the expectations of the Syrian poleis and adopted the same sort of relationship with the Syrian poleis as they had had with their Seleukid overlords. To Plutarch, this relationship probably did not look very different from Oriental tyranny, but if the poleis had not appreciated Tigranēs' style of rule, they could have acted against him. In their interactions with Tigranēs, the Syrian poleis had many of the advantages which Asia Minor had possessed relative to the Seleukid kings: Syria was a newly absorbed territory of the Armenian kingdom, distant from the kingdom's core, and contested with a number of other powers (Parthians, Ptolemies, Nabataeans, and various Seleukid pretenders). If the poleis had wanted Tigranēs to treat them as independent allies, they were in as good a bargaining position as the poleis of Asia Minor had been under the Seleukids. Tigranēs presented himself to the Syrian poleis in the manner of a Seleukid king because that was still the style of rule which they desired. Thus, while the poleis clearly became more assertive in their interactions with the kings as the Seleukid dynasty weakened, they still wished to exist under the aegis of Seleukid royal power.

${ }^{609}$ Ibid. 


\section{CONCLUSION: THE SELEUKID POLIS}

For the poleis of the Seleukid heartland, dependence on the king seems to have had a value which outweighed its disadvantages. These disadvantages were not inconsiderable: the kings interfered deeply in their affairs both informally and institutionally. This interference affected everyday life in a substantial way: royal soldiers were garrisoned in the cities and royal officials witnessed - and taxed - everyday commercial transactions. Aside from these practical expenses, subordination had an ideological cost which the poleis of Asia Minor found very expensive. In Asia Minor, the kings and the poleis worked very hard to present Seleukid overlordship as alliance - the kings recognised the poleis' right to extensive freedom of action and the poleis strove to act as independently as possible. In Syria and Mesopotamia, however, the poleis were on a far shorter leash and did not strain on it nearly as hard.

For most of the Hellenistic Period, the poleis of Syria and Mesopotamia did not really have a choice. Sitting in the heartland of the Seleukid realm, they were essential to the kings' rule in a way that the poleis of Asia Minor simply were not. The poleis of the heartland were essential hubs for the transport of resources, money, and troops across the empire. They were showcases for the prosperity of their overlords. They became centres from which the wealth of the countryside could easily be extracted and converted into cash wealth. They were a place where defeated peoples could be integrated into the realm. For these poleis to be or have striven to be independent would have threatened a major basis of Seleukid royal power. The kings installed massive garrisons, to force the cities' loyalty, but from their foundation the kings also endeavoured to make the poleis amenable to royal control, so that control did not require force. They constructed their new foundations to be like the poleis of Asia Minor and Mainland Greece in form and institutional structure, but built concord between city and king into their ideological and administrative structures.

Subordination to the kings was not absolute: the poleis of the Seleukid heartland were allowed a limited degree of agency. IGLS 4.1261 from Laodikeia-by-the-Sea shows that the poleis were generally allowed to manage their own affairs in matters in which the king was not interested, which might nevertheless be matters of great import to the polis in question. When the king interfered directly, as in IGLS 3.2.1183 from Seleukeia-inPieria, the poleis acknowledged royal letters as commands, but they could still assert 
agency by presenting obedience as being in their own interest. Thus, the poleis exercised sufficient internal self-government to consider themselves poleis.

The identities of the poleis in Asia Minor were based on a long history of local names, myths, and symbols. These referred to a time (mythical or historical) when the poleis had been independent and their expression was thus in opposition to the kings. The Seleukids' new poleis in Syria and Mesopotamia were different. They were named after the kings, their founder-myths centred on their settlement by the kings, and their symbols were largely those of the dynasty. These symbols did not recall an independent existence. On the contrary, they reinforced the idea that the poleis were dependent on the kings and that they were Seleukid. When the poleis asserted their local polis identity, they expressed a Seleukid identity as well, not their independence. The semi-civic coinage issued under Antiochos IV and Alexandros I is a clear example of this synthesis of civic and royal symbolism in practice. The endurance of these Seleukid symbols and myths long after the Seleukid dynasty had fallen indicates how entrenched they were as part of the poleis' identities.

Furthermore, subordination to the kings was in the interest of the civic elites. The civic governments of the poleis were based upon a partnership between the royallyappointed epistatès and the civic magistrates. The epistatēs straddled the royal and civic spheres - voice of the king to the city and voice of the city to the king, his power in each sphere predicated on the idea that he was the representative of the other sphere. The magistrates represented a small citizen body and needed the support of an external source of authority, too, to help maintain their position. Concord between epistatēs and the magistrates - between the royal and civic spheres - was thus essential for both parties and is therefore stressed in IGLS 3.1183 and IGLS 4.1261.

The Seleukids had not killed the polis in bringing it to Syria and Mesopotamia, but they had significantly altered it. The Syrian and Mesopotamian poleis were, therefore, distinct from those of Asia Minor - their symbols of identity and internal structures encouraged them to desire subordination to an external sovereign, in a way that the poleis of Asia Minor found very difficult. It was this new Seleukid model, which allowed the polis to have a local identity and to submit to a higher power which represented the poleis' future - they would continue to enjoy wealth and prosperity on a scale hitherto undreamt, but they would never be completely free again. 


\section{APPENDIX ONE: INSCRIPTIONS USED}

\begin{tabular}{|c|c|c|c|c|}
\hline & Source & Date(BC) & Concordance & $\begin{array}{c}\text { Full Text } \\
\text { on Page }\end{array}$ \\
\hline F. Amyzon 16 & Amyzon, Karia & c. $200 \mathrm{BC}$ & PH 256814 & 117 \\
\hline Hefzibah & Jordan River Valley & $202-195$ & Landau (1966) & 118 \\
\hline I. Erythrae 23 & Erythrai & $330-315$ & SEG 19.697 & 120 \\
\hline I. Erythrae 205 & Erythrai & 281 & PH 251553 & 120 \\
\hline I. Priene 22 & Priēnē & 262 & PH 252959 & 121 \\
\hline $\begin{array}{l}\text { IGLS 3.2.1183 } \\
\text { Theophilos } \\
\text { Decree }\end{array}$ & Seleukeia-in-Pieria & 186 & $\begin{array}{l}\text { Holleaux (1933); Köhler } \\
\text { (1900) ; PH 243366; } \\
\text { RC 45; SEG } 7.62\end{array}$ & 122 \\
\hline IGLS 3.2.1184 & Seleukeia-in-Pieria & $187-175$ & OGIS 245; PH 243367 & 124 \\
\hline IGLS 4.1261 & Laodikeia-by-the-Sea & 174 & $\begin{array}{l}\text { PH 243485; Sosin } \\
(2005)\end{array}$ & 125 \\
\hline IGLS 7.4028 & Baitokaikē & $? ? ? ?$ & $\begin{array}{l}\text { OGIS 262; PH 245340; } \\
\text { RC } 70\end{array}$ & 126 \\
\hline $\begin{array}{l}\text { Inscription } \\
\text { d'Iran }\end{array}$ & Laodikeia-in-Mēdia & 193 & $\begin{array}{l}\text { PH } 314705 \& 314706 ; \\
\text { Robert (1949) }\end{array}$ & 128 \\
\hline OGIS 222 & Klazomenai & $268-262$ & $\begin{array}{l}\text { I. Erythrae 504; Piejko } \\
\text { (1991); PH 251881 }\end{array}$ & 130 \\
\hline OGIS 223 & Erythrai & $261-246$ & $P H 251595 ; R C 15$ & 132 \\
\hline OGIS 225 & Didyma (Milētos) & 253 & PH 247011; RC 18 & 134 \\
\hline OGIS 233 & $\begin{array}{l}\text { Magnēsia-on-the- } \\
\text { Maiandros }\end{array}$ & c. 195 & PH 260454 & 136 \\
\hline OGIS 253 & Mesopotamia & 166 & PH 321688 & 140 \\
\hline OGIS 254 & Mesopotamia & $? ? ? ?$ & PH 314545 & 140 \\
\hline OGIS 257 & Seleukeia-in-Pieria & 109 & PH $310762 ; R C 71$ & 141 \\
\hline OGIS 339 & Sestos & $133-120$ & PH 166666 & 142 \\
\hline SEG 35.925 & Chios & c. 330 & $\begin{array}{l}P H 246413 ; \text { SEG } 22.506 ; \\
S_{l l l^{3}} 283\end{array}$ & 148 \\
\hline SEG 36.1280 & Seleukeia-in-Pieria & 197 & & 149 \\
\hline Syll $^{3} 344$ & Teos & 303 & PH 256448; RC 3/4 & 150 \\
\hline Syll $^{3} 560$ & $\begin{array}{l}\text { Magnēsia-on-the- } \\
\text { Maiandros }\end{array}$ & c. $195 ?$ & PH 260467 & 158 \\
\hline
\end{tabular}




\section{Epigraphic Corpora}

F. Amyzon: Robert Jeanne \& Louis Robert. 1983. Fouilles d'Amyzon en Carie, I. Exploration, histoire, monnaies et inscriptions. Paris: De Boccard.

Hefzibah: Landau, Y.H. 1966. "A Greek Inscription Found near Hefzibah.” Israel Exploration Journal 16: 54-70.

Holleaux, Maurice. 1933. "Une inscription de Séleucie-de-Pierie." Bulletin de Correspondance Hellénique 57: 6-67.

I. Erythrae: Engelmann, Helmut \& Reinhold Merkelbach. 1973. Die Inschriften von Erythrai und Klazomenai. Bonn : Rudolf Habelt Verlag.

I. Priene: Fredrich, C., H. Von Prott, H. Schrader, T. Wiegand \& H. Winnefeld. 1906. Inschriften von Priene. Berlin: Verlag von Georg Reimer.

IGLS: Jalabert, Louis, René Mouterde et al. 1870-1970. Inscriptions Grecques et Latines de la Syrie. Paris: Libraire Orientaliste Paul Geuthner.

Inscription d'Iran: Robert, Louis. 1949. "Inscriptions Séleucides de Phrygie et d'Iran." Hellenica 7: 5-29.

Köhler, Ulrich. 1900. “Zwei Inschriften aus der Zeit Antiochos' IV Epiphanes." Sitzungsberichte der koniglich Preussischen Akademie der Wissenschafte zu Berlin 51: 1100-1108.

PH: The Packard Humanities Institute. Searchable Greek Inscriptions. http://epigraphy. packhum.org/inscriptions/

Piejko, F. 1991. "Decree of the Ionian League in Honor of Antiochus I, CA 267-262 B.C." Phoenix 45: 126-147.

RC: Welles, Charles Bradford. 1966. Royal Correspondence in the Hellenistic Period. Rome: "L'Erma” di Bretschneider.

OGIS: 1903-1905. Orientis Graeci Inscriptiones Selectae. Leipzig: Herzel

Sosin, Joshua D. 2005. "Unwelcome Dedications: Public Law and Private Religion in Hellenistic Laodicea by the Sea." The Classical Quarterly, N.S. 55: 130-139.

Syll ${ }^{3}$ : Dittenberger, W. 1915-1924. Sylloge Inscriptionum Graecarum. 3rd Ed. Leipzig. 


\section{F. Amyzon 16 : Amyzon, Karia : c.200 BC}

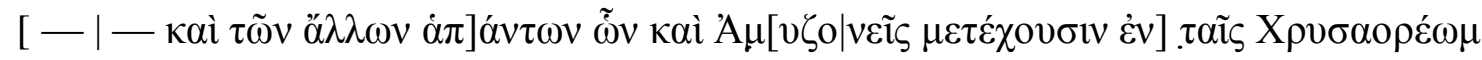
$\pi \hat{\lambda} \varepsilon[\sigma \mathrm{\sigma} v \cdot$

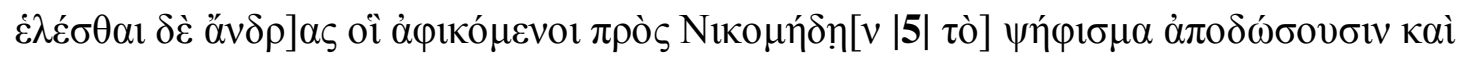

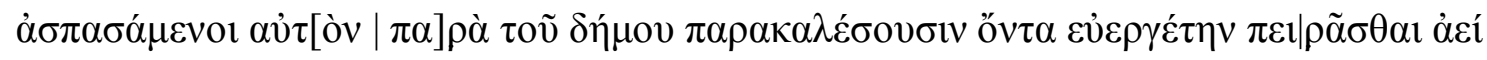

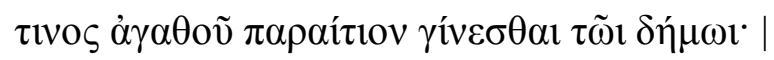

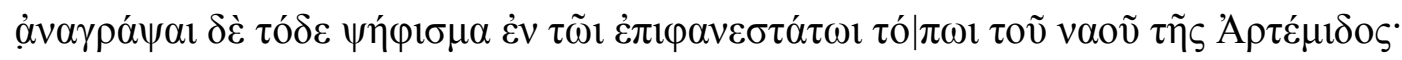

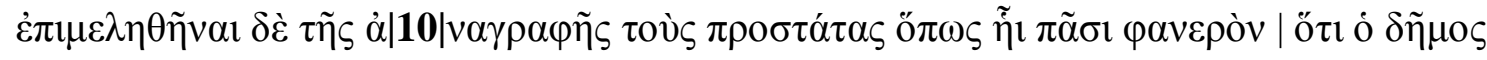

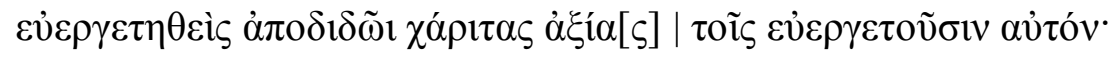

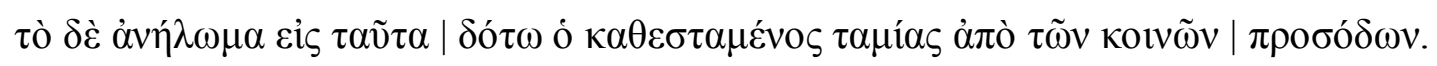

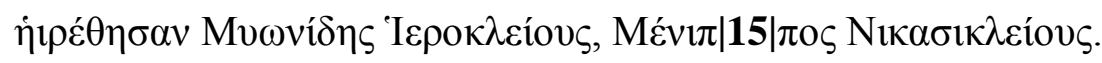

[The dèmos decides]:

- [To grant Nikomēēes citizenship? and all other] things also which the Am[yzonians share with] the poleis of the Chrysaoreans

- To choose men] who will go to Nikomēdēs and give him this decree and greeting him kindly on behalf of the demos will encourage him, as a benefactor, to always try to be the cause of something good for the demos,

- To inscribe this decree in the most prominent place in the temple of Artemis

- That the prostatai are to take care of the inscription so that it may be apparent to all that when the dèmos receives beneficence it repays the benefactor with gratitude worthy of itself

Let the man who has been appointed treasurer provide the cost of these things from the common income.

The men chosen: Myōnidēs of Hierokleios, Menippos of Nikasikleios 


\section{Hefzibah : Jordan River Valley, south of Galilee : 200-195 BC}

A

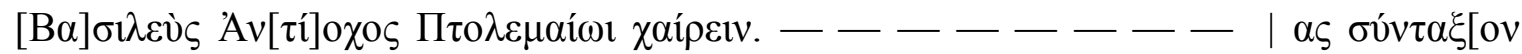

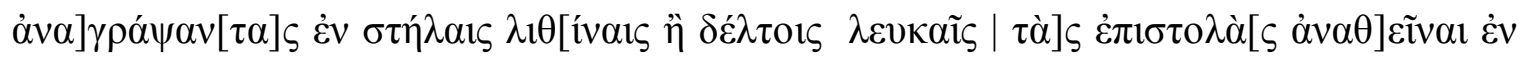

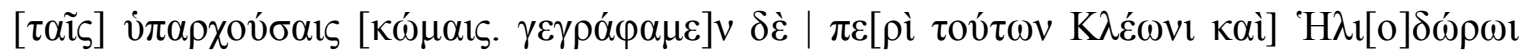

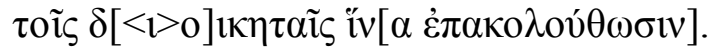

$\beta \imath \rho^{\prime} \mathrm{Y} \pi \varepsilon \rho \beta \varepsilon \rho \varepsilon \tau \alpha[$ íov - ]

King Antiochos to Ptolemaios, greetings. $-\ldots-\ldots-\ldots-$ arrange for the epistolai to be engraved on stone steles or [white tablets] and se[t up] in the [villages] under your control. [We have written] abo[ut these things to Kleōn and] Hēliodōros the dioiketai, in order to follow it up.

- Hyperberetaios, 112 SE [200 BC]

B

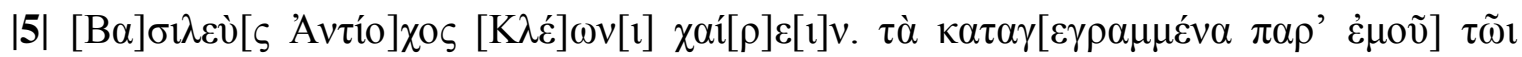

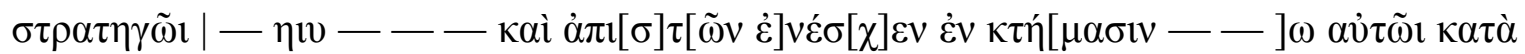

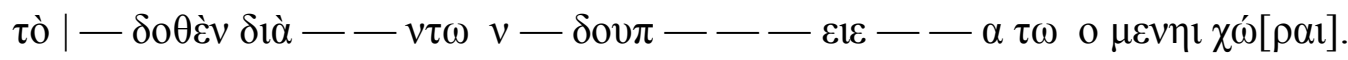

[K]in[g Antio]chos [to Kle]ōn, Greetings. The things w[ritten] below to the stratēgos [by me] — _ _ - and he, disobeying, held on to the properties — - to him below - thing given by $-\ldots \ldots-\ldots-\ldots-\ldots-$ la[nds].

\section{C}

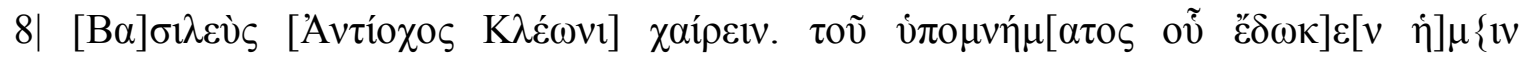

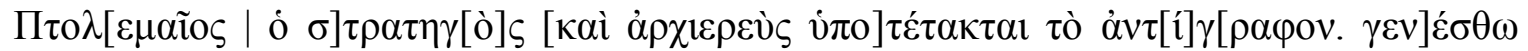

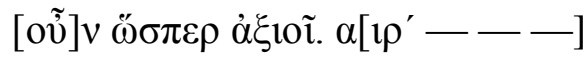

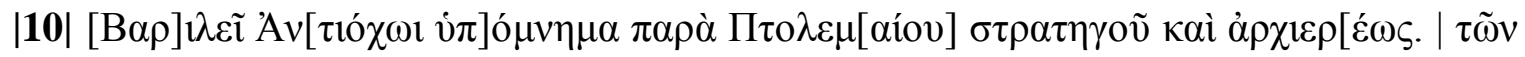

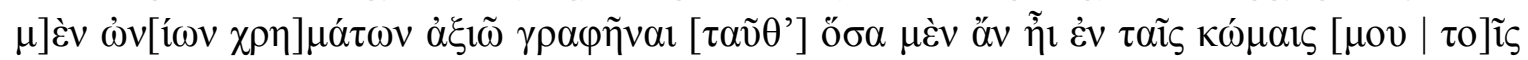

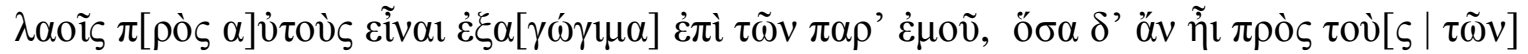

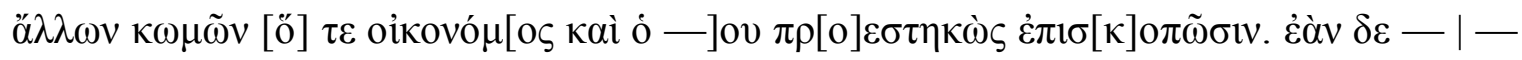

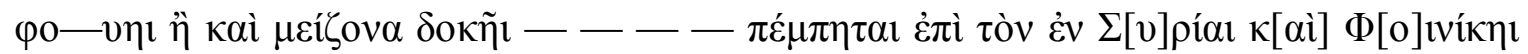

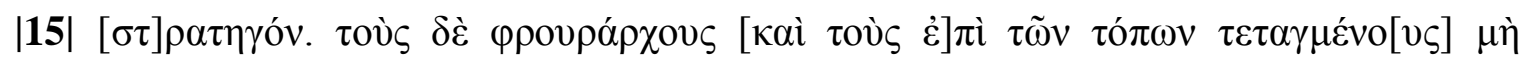

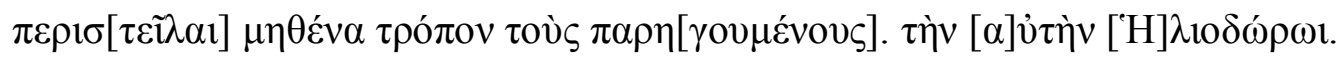

[K]ing [Antiochos to Kleōn], greetings. Attached is a copy of the hypomnēma which [Ptolemaios the] stratēgos and archpriest [gav]e to us. So, let it be done as he thinks best [11]1 SE [201 BC]

Hypomnēma to [Kin]g An[tiochos] from Stratēgos and Archpriest Ptolemaios. About goods on sale, I think best to write [these things]: whatever is exp[orted] by the commoners in [my] villages to themselves be administered by my officials, but the oikonomos and the - administrator would oversee whatever is [exported] to commoners of other villages. And if $-\ldots-$ or he wishes more $-\ldots-\ldots$ he would send to the stratēgos of Syria and Phoenicia. And that the phrourarchoi and those set over the places should not pro[tect] in any way those who are led astray. The same (letter) to Hēliodōros. 
D

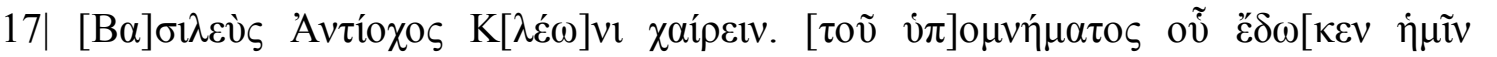

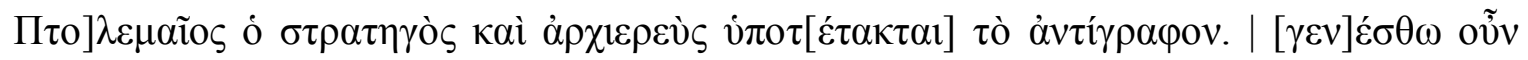

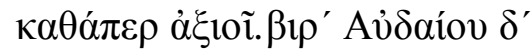

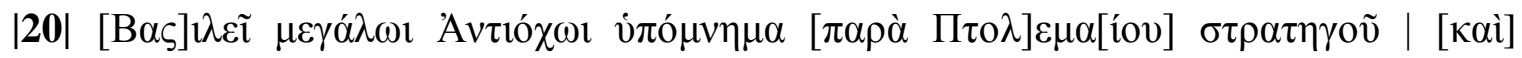

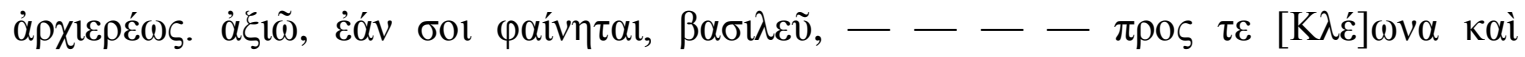

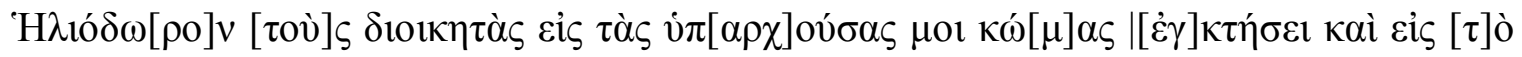

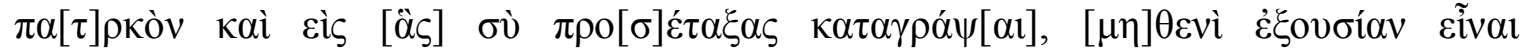

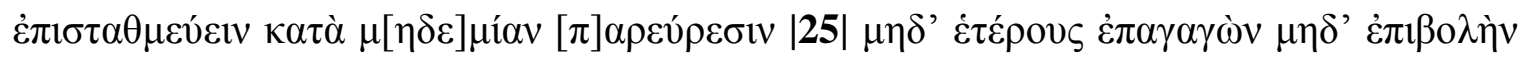

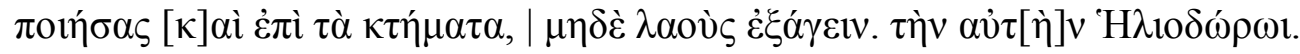

[K]ing Antiochos to $\mathrm{K}[\mathrm{leo}] \mathrm{n}$, greetings. Attached is a copy of the hypomnēma which [Ptolemaios the] stratēgos and archpriest [gav]e to us. So, let it be done as he thinks best. $4^{\text {th }}$ Audanios, 112 SE $[200 \mathrm{BC}]$

Hypomnèma to King Antiochos the Greatest [from] Stratēgos [and] Archpriest Ptol]ema[ios]. I think best, if it should seem so to you, King, — — — that there be no authority for the dioikêtai [Kle]ōn and Hēliodō[ro]s to billet in the villages belonging to me by tenure, in my hereditary land, and in the land which you commanded to be deeded to me under any pretext, nor for bringing in others, nor for making requisitions (even for property), nor to take away the commoners. The same (letter) to Hēliodōros.

E

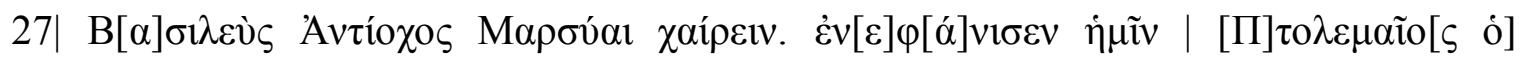

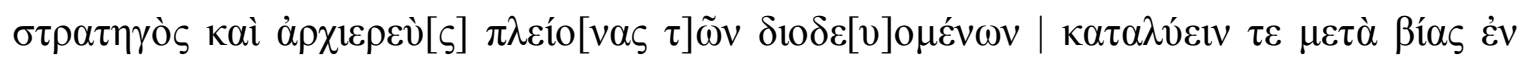

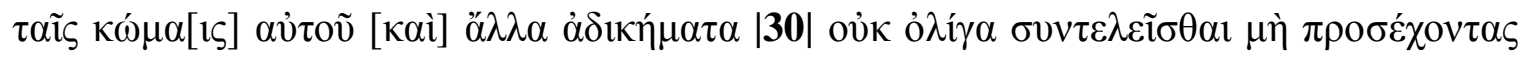

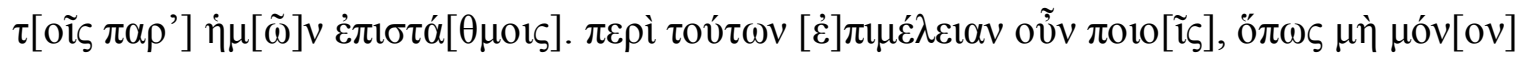

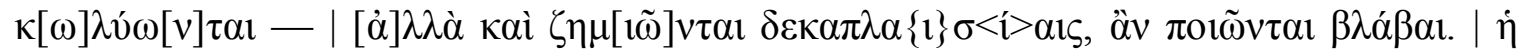

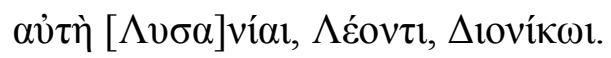

$\mathrm{K}[\mathrm{i}] \mathrm{ng}$ Antiochos to Marsyas, greetings. [P]tolemaio[s the] stratēgos and archpries[t] reported to us that the majority of those passing through ignored our quartermasters and encamped by force in his villages and carried out not a few other crimes. So you should issue an order about these things that not only are they to be stopped - but also that they are to be fineded tenfold, should damage be done. The same (letter) to [Lysa]nias, Leōn, Dionikos.

\section{$\mathbf{F}$}

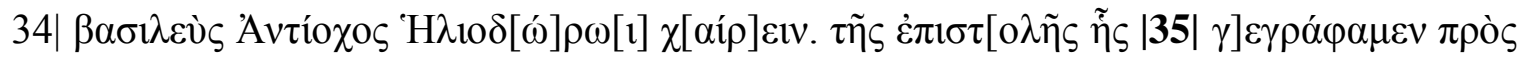

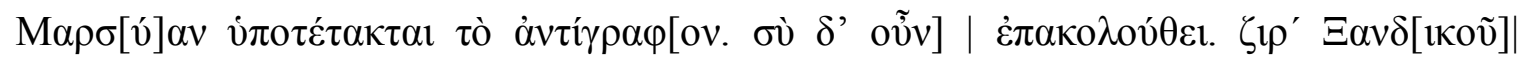

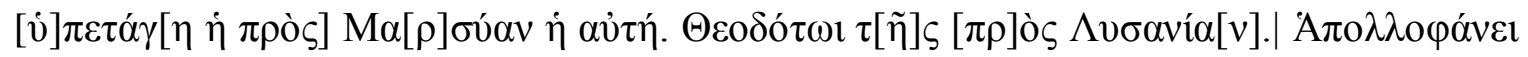

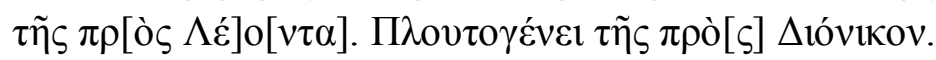

King Antiochos to Hēliodōros, greetings. Attached is a copy of the epistol[e $\bar{e}$ which] we have written to Marsyas. [So] comply with it. Xandikos, 116 SE [195 BC] The same (letter) to Marsyas (attached above); to Theodotos of the one for Lysanias; to Apollopanēs of the one to Leōn; to Ploutogenēs of the one to Dionikos. 


\section{Erythrae 23 : Erythrai : 330-315 BC}

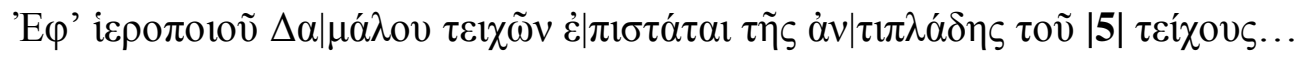

When Damalos was hieropoios, the overseers of the walls for damp-proofing the wall...

\section{Erythrae 205 : Erythrai : 281 BC}

Appended to an early fourth century BC inscription on the cult of Askleppios and Apollo

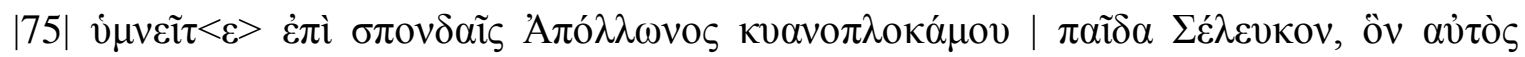

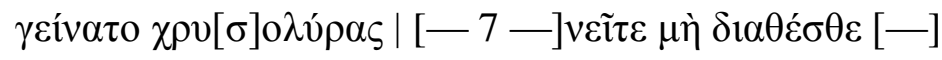

Sing with libations of Seleukos, son of dark-haired Apollo, who himself made golden lyres — - lest you arrange - 


\section{Priene 22 : Priēnē : 262 BC}

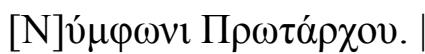

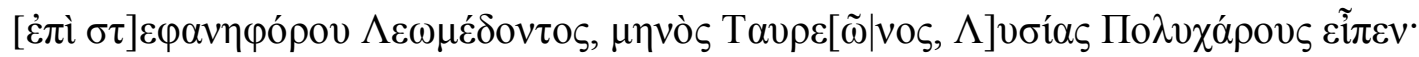

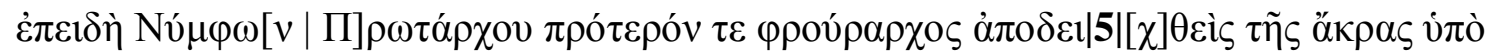

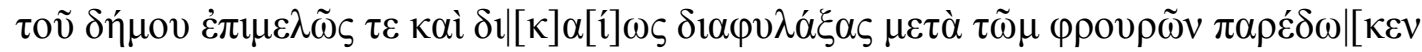

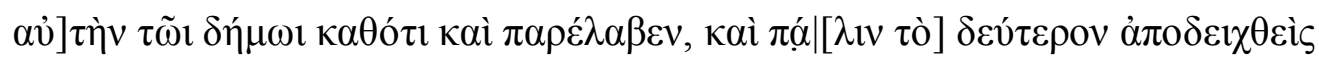

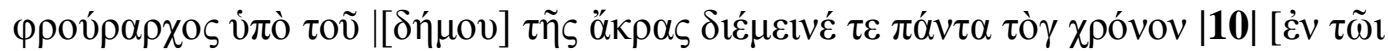

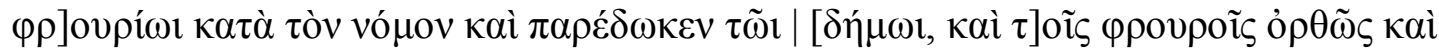

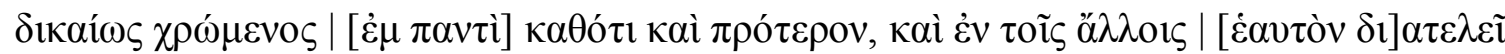

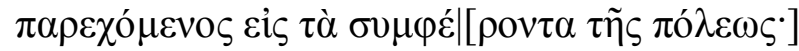

$\tau u ́ x \eta \imath \dot{\alpha} \gamma \alpha \theta \tilde{\eta} \imath$.

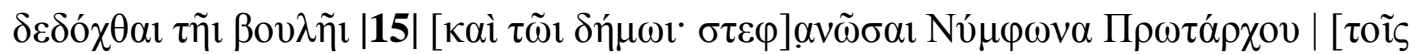

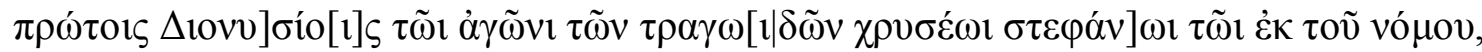

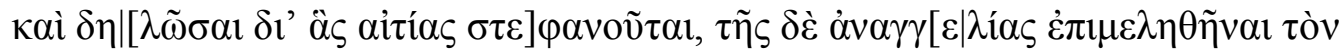

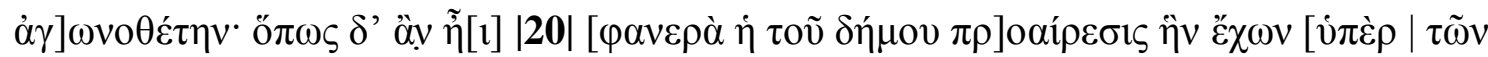

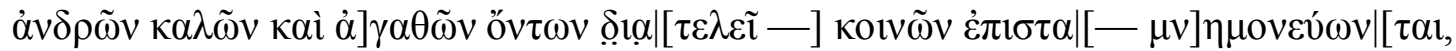

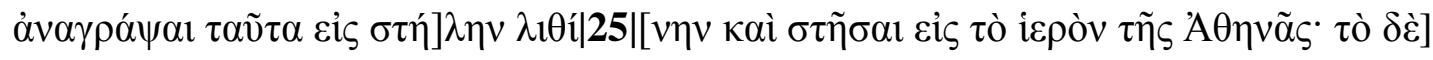

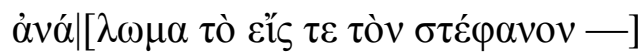

For Nymphōn son of Prōtarchos.

[When] Leōmedōn was crownbearer, in the month of Taureōn, Lysias son of Polycharos said:

Since Nymphōn son of Prōtarchos who was formerly appointed phrourarchos of the citadel by the demos, maintained the guard attentively and correctly along with the guardsmen, and return[ed it] to the dēmos, just as he received it and again, when appointed phrourarchos of the citadel by the demmos a second time, continued to behave according to the law for the whole time in the garrison and returned it to the [demos, and] managed the guards correctly and justly [in everything] just as before, and in other matters continued to offer [himself] for the benef[it of the polis].

Good Fortune!

It has been resolved by the boulē [and the dēmos] to crown Nymphōn son of Prōtarchos [in the first days of Dionysios] at the tragedy contest, [with a gold] crown as from custom, and to make known the [the reasons why] he is crowned, and for the organiser of the contest to organise the proclamation. And so that [the dēmos'] goodwill, which it continues to have [for men who are well and good] may be apparent — [and so that that these deeds?] may be remembered in common know[ledge? -, to write these things on a] stone stel[e and set it up in the temple of Athena. And the expense for the crown and - 


\section{IGLS 3.2.1183, Theophilos Decree : Seleukia Pieria : 186 BC}

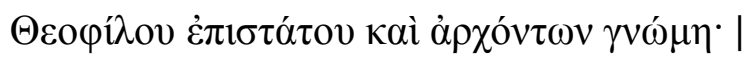

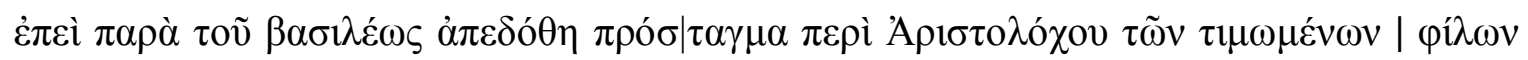

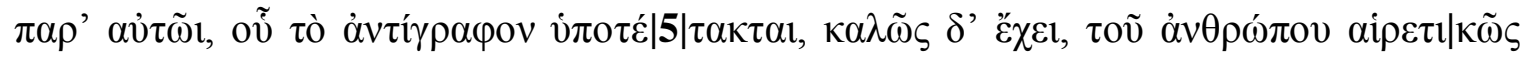

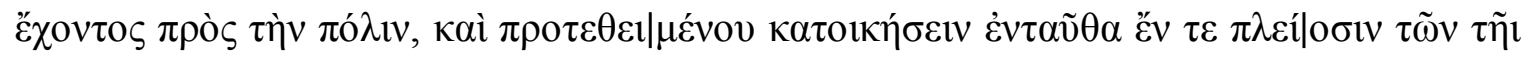

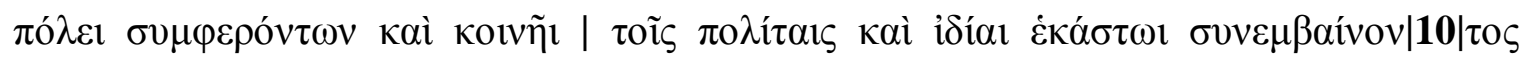

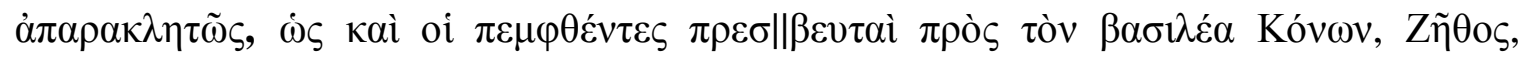

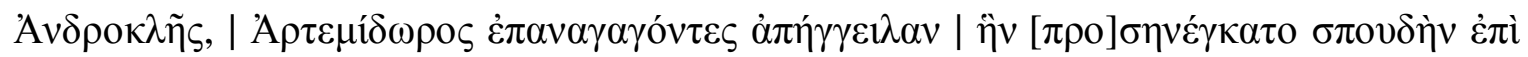

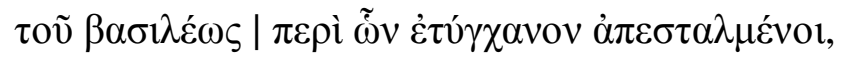

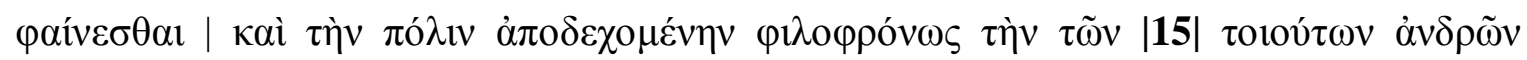

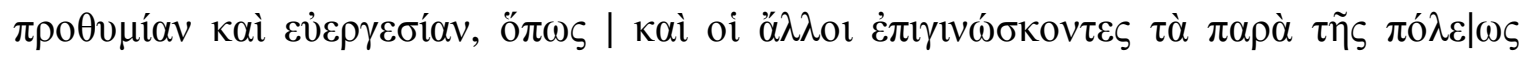

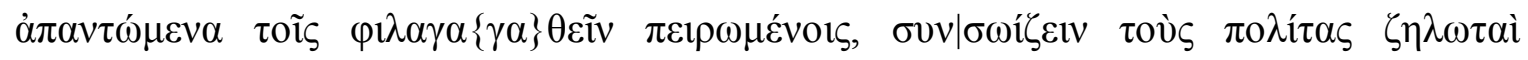

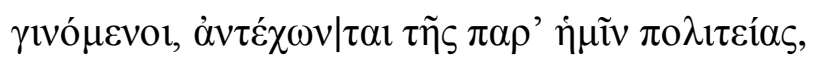

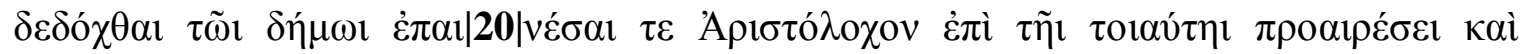

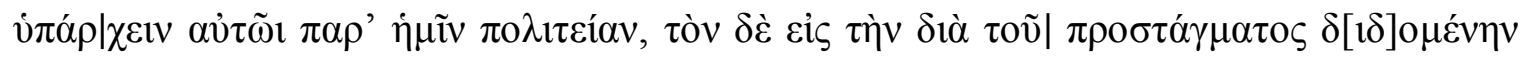

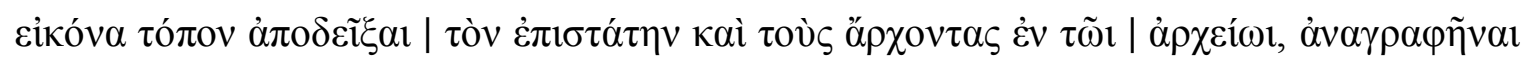

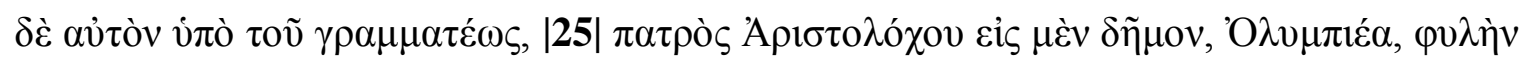
| $\delta \dot{\varepsilon} \Lambda \alpha o \delta \iota \kappa i \delta \alpha . \mid$

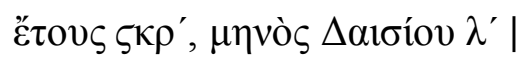

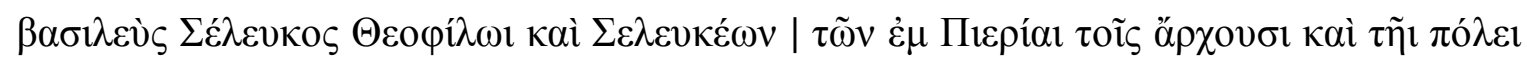

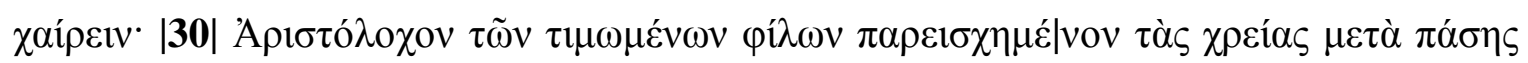

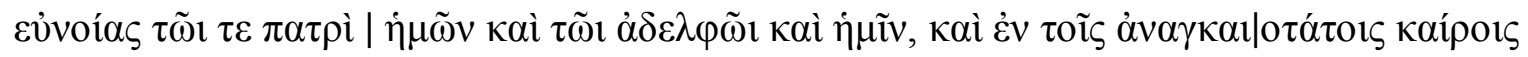

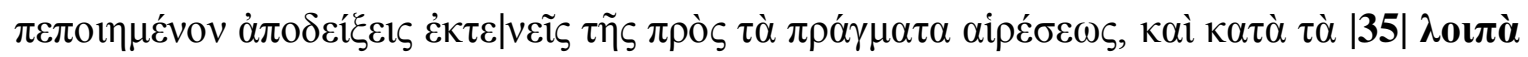

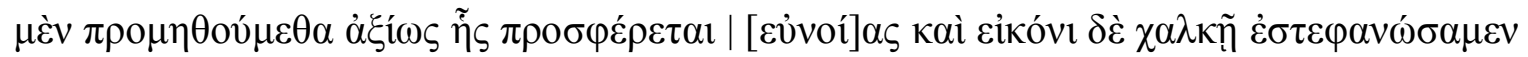

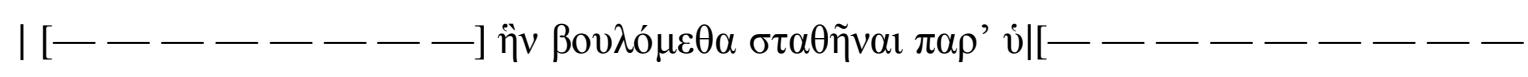

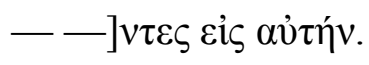


Proposal of Epistatēs Theophilos and the Archons:

Since a prostagma was delivered from the king concerning Aristolochos, one of the honoured friends near to him (of which a copy is appended below) it is appropriate that, as this man, acting with goodwill to this city and having chosen to settle down here, in many cases [he] has both been of advantage to the city and has voluntarily aided the citizens publicly and individuals privately, and, moreover, Konōn, Zēthos, Androklēs, [and] Artemidōros, the ambassadors who were sent to the King and have returned, reported how much trouble he went to with the King regarding the matters for which they were sent,

And, so that the polis be seen to welcome the goodwill and beneficence of such men, in order that others also, learning what comes from our city to those who endeavour to love goodness and becoming imitators of [him in] preserving the citizens, might care for our community,

It has been resolved by the dèmos:

- To commend Aristolochos for such conduct and to grant our citizenship to him,

- To consecrate, for the statue given [to him] by your command, the place [of] the epistatēs and archons in the Town hall,

- And that he is to be enrolled, by the secretary, as the son of Aristolochos, in the deme of Olympieus and the tribe of Laodikis

Year 126, $30^{\text {th }}$ of Daisios

[186 BC, $31^{\text {st }}$ May]

King Seleukos to Theophilos and to the archons and city of the Seleukeians-in-Pieria, greetings. Because Aristolochos of our honoured friends furnished the needs of our father, brother, and ourselves with total goodwill, and in most fraught times has eagerly demonstrated his devotion to our affairs, and in other respects, we consider him worthy of the goodwill which he embodies and we have honoured him with a bronze statue [-

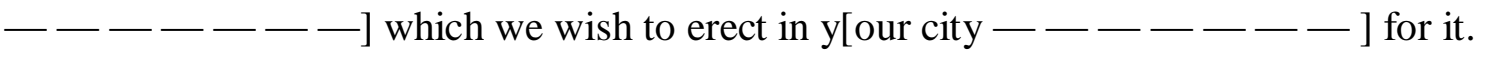


A

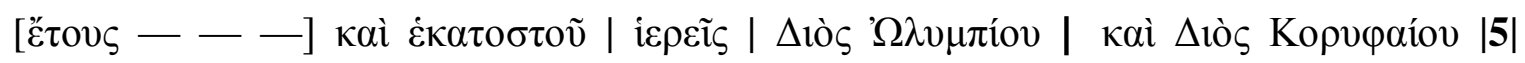

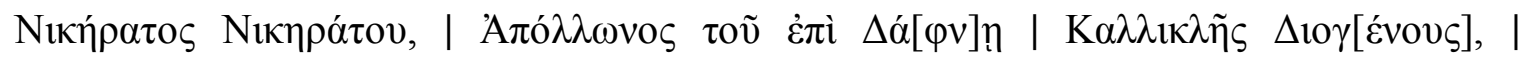

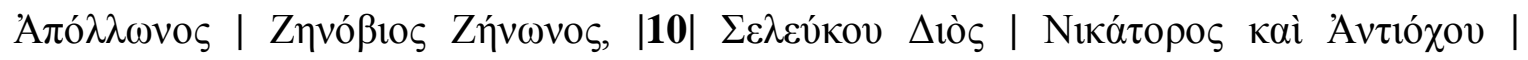

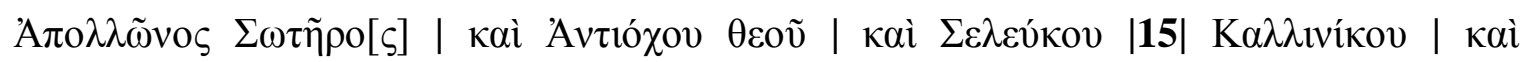

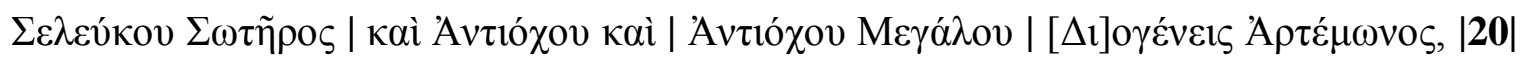

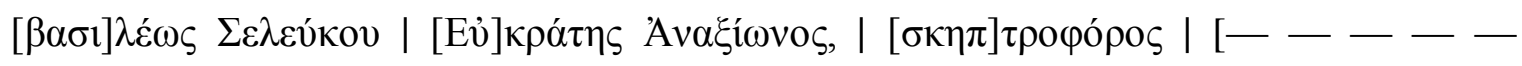

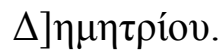

Priests in the hundred and $\left[-\ldots \_\right]^{\text {th }}$ year: Of Zeus Olympios and of Zeus the Chief: Nikēratos son of Nikēratos; of Apollo at Daphnē: Kalliklēs son of Diogenēs; of Apollo...: Zēnobios son of Zēnōn; of Seleukos [I] the Victorious Zeus, Antiochos [I] the Saviour Apollo, Antiochos [II] the God, Seleukos [II] the Beautiful Victor, Seleukos [III] the Saviour, Antiochos, and Antiochos [III] the Greatest: Diogenēs son of Artemōn; of King Seleukos [IV: Eu]kratēs son of Anaxiōn; [sceptre?]bearer: [- $-\ldots-\ldots$ ] son of Dēmētrios.

\section{B}

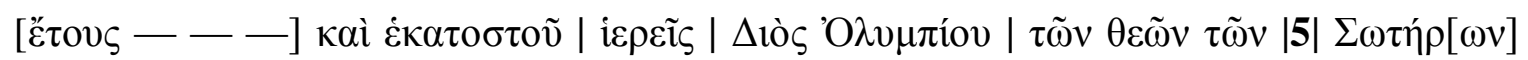

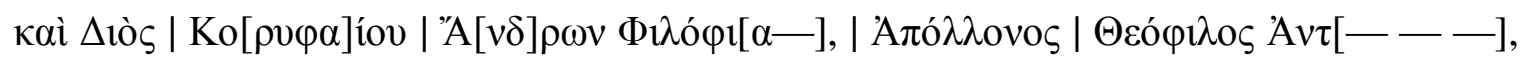

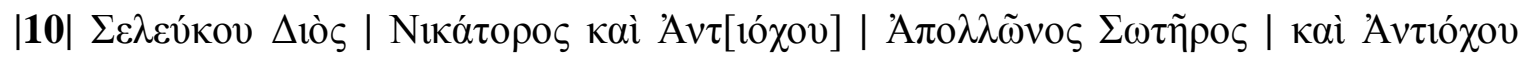

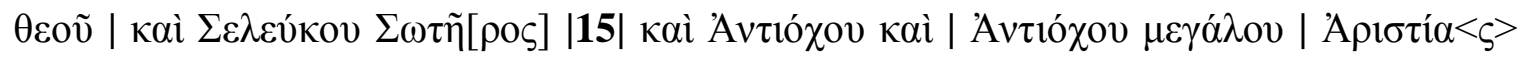

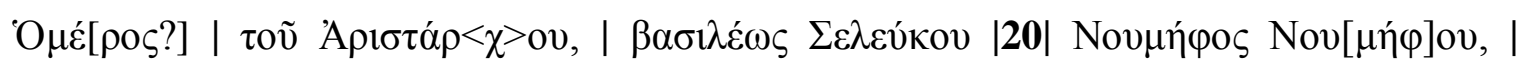

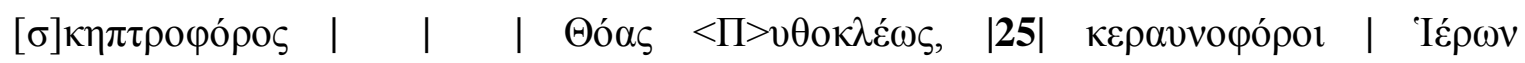

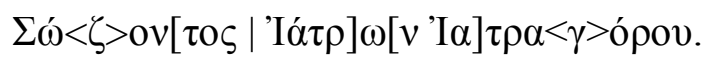

Priests in the hundred and $[-\ldots-]^{\text {th }}$ year: Of Zeus Olympios of the Saviour Gods and of Zeus the Chief: A[nd]rōn son of Philophi[a-]; of Apollo: Theophilos son of Ant[- - ], of Seleukos [I] the Victorious Zeus, Ant [iochos I] the Saviour Apollo, Antiochos [I] the God, Seleukos [III] the Saviour, Antiochos and Antiochos [III] the Greatest: Aristias son of Home[ros?] grandson of Aristarchos; Of King Seleukos [IV]: Noumēphos son of Nou[mēph]os. Sceptrebearer: Thoas son of Pythoklēs; Thunderbearers: Hierōn son of Sōzōn, [Iatr]ō[n] son of [Ia]tra[g]oros 


\section{IGLS 4.1261: Laodikeia by the Sea : $174 \mathrm{BC}$}

ह̌ं

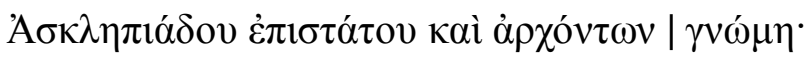

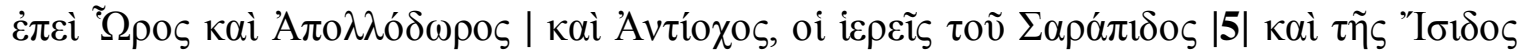

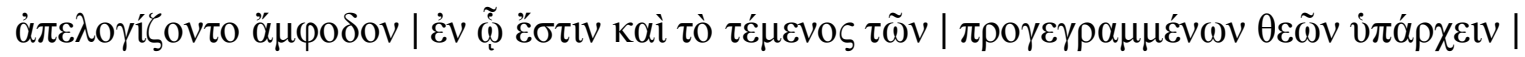

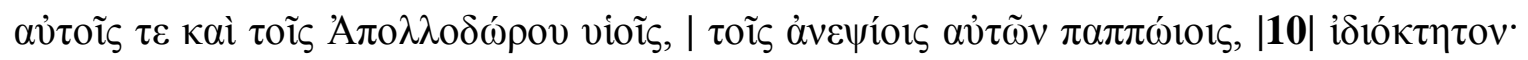

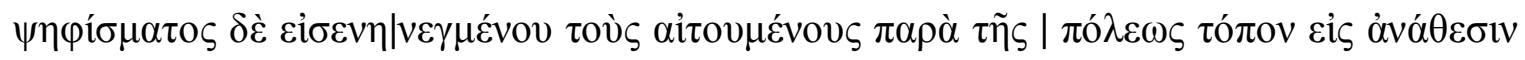

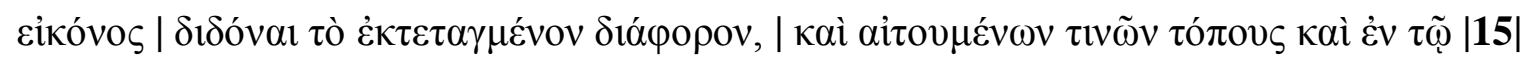

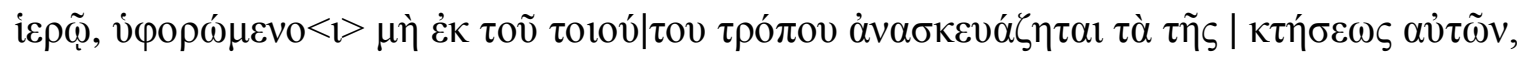

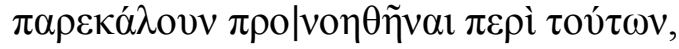

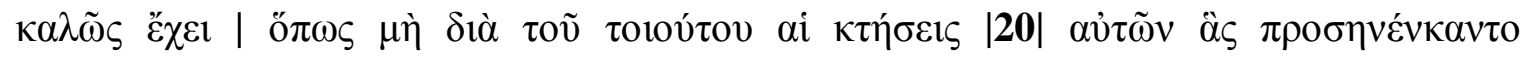
$\dot{\alpha} v \alpha \mid \sigma \kappa \varepsilon v \alpha \dot{\zeta} \omega v \tau \alpha l \cdot$

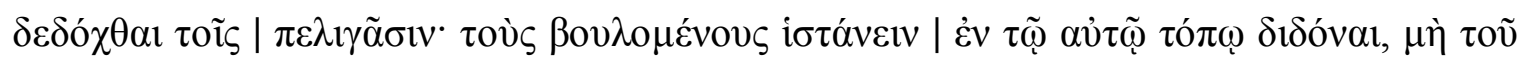

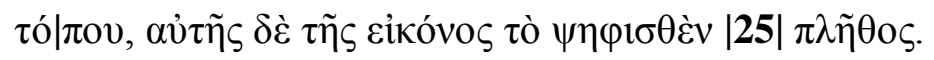

Year $138[174 \mathrm{BC}] 30^{\text {th }}$ of Audanios.

Proposal of Epistatēs Asklēpiadēs and the archons:

Since Hōros, Apollodōros and Antiochos, the priests of Sarapis and Isis rendered an account of their city-block in which there is the sanctuary of the aforementioned gods controlled by them and their first cousins, the sons of Apollodōros, which is their private property and as a motion has been passed that those asking for civic land for dedication of statues are to give a fixed sum of money and some have asked for places in their temple, they suspect that their possessions will be wrecked by such practices and they called for provision to be made in these matters.

It is appropriate that their possessions, which they have offered up, not be wrecked through such practices;

[so] it has been resolved by the peliganes: that those wishing to set up [statues] in their sanctuary are to give the amount decreed, not for the site, but for the statue itself. 
IGLS 7.4028 : Baitokaikē : ???= OGIS 262 = RC 70

A letter in Latin from the Emperors Valerian and Gallienus (r.AD 253-259) precedes

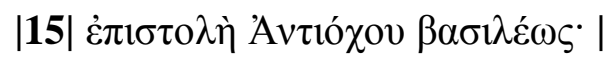

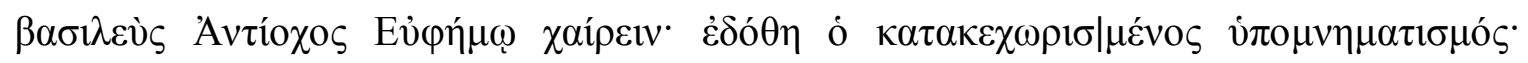

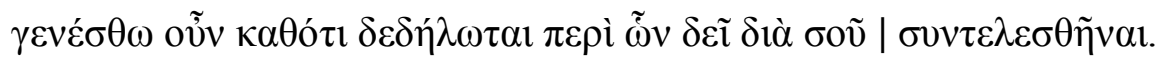

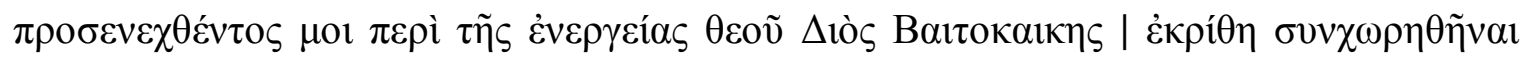

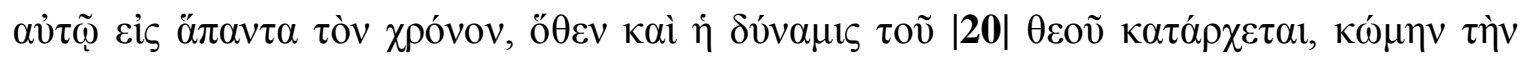

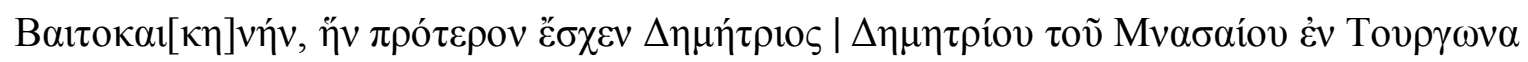

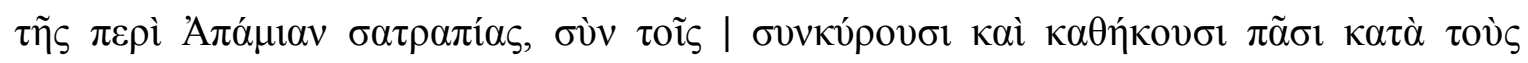

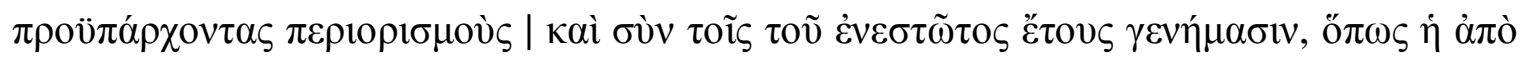

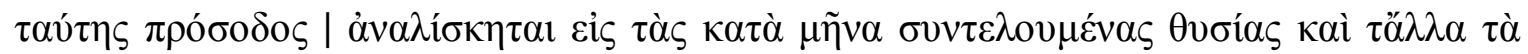

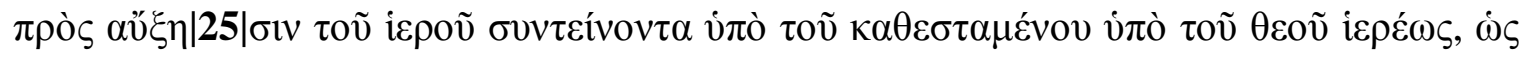

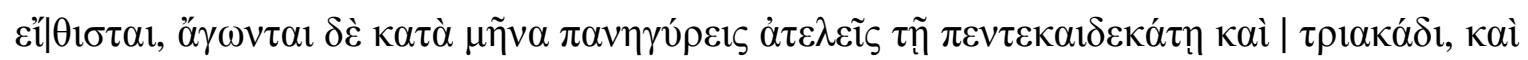

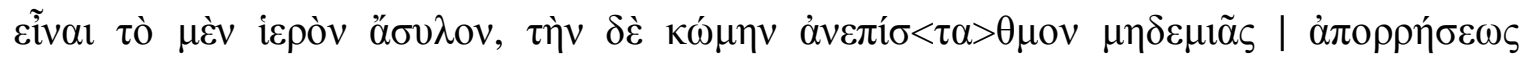

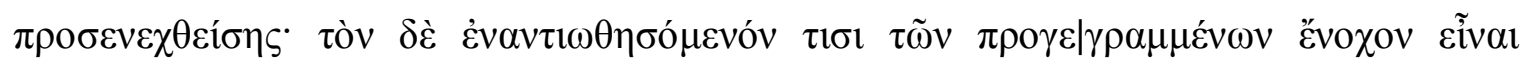

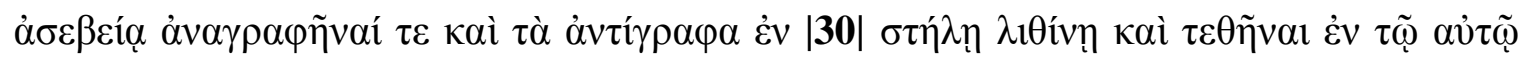

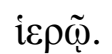

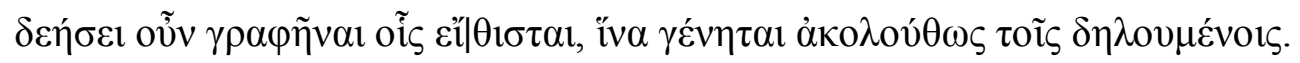


Letter of King Antiochos:

King Antiochos to Euphēmos, greetings. The hypomnèmatismos recorded below was granted. So let it be just as it has been instructed in regards to these things, which must be accomplished by you.

As I was informed about the efficacy of divine Zeus of Baitokaikē, it was decided:

- for him to be granted for all time the village of Baitokai[kē]nē, which Dēmētrios son of Dēmētrios of Mnasaios in Tourgōn of the satrapy around Apameia formerly held, from which the power of the god may receive sacrifices, with the contiguous [land] and everything which belongs to it according to the archived surveys and with the harvest of the current year, in order that the income from the land might be used for performing sacrifices each month and in order that the other contributions be used for the expansion of the temple by the priest appointed for the god, as is customary, and in order that untaxed fairs may be held each month on the fifteenth and the thirtieth,

- And that the temple is to be a sanctuary, and for the village to be exempt from billeting (no objection having been offered),

- And that anyone who opposes any part of this proclamation shall be guilty of impiety,

- And that copies are to be inscribed on a stone stele and placed in the temple itself.

So it will be necessary to write to those who are normally written to, so that it is done in accordance with these instructions. 


\section{Inscription d'Iran : Laodikeia-in-Mēdia : 193 BC}

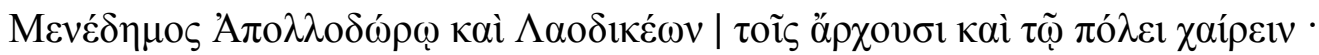

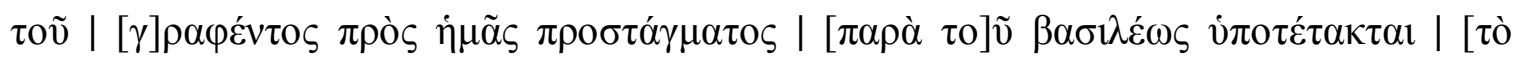

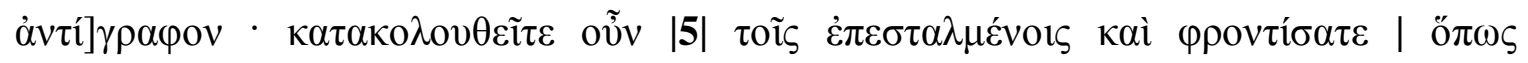

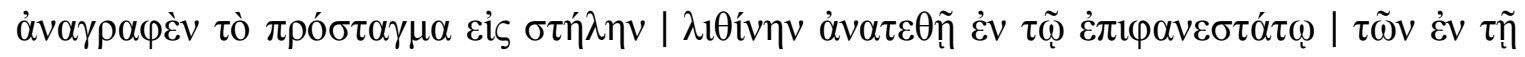
$\pi$ $\lambda \varepsilon 1$ i $\varepsilon \rho \tilde{\omega} v . \mid$

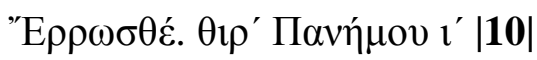

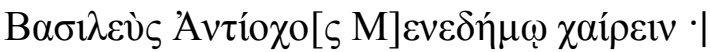

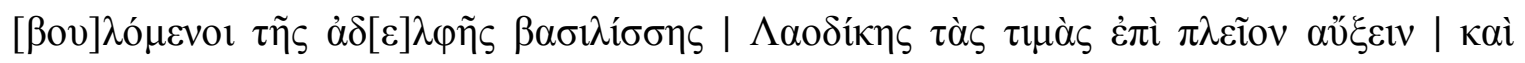

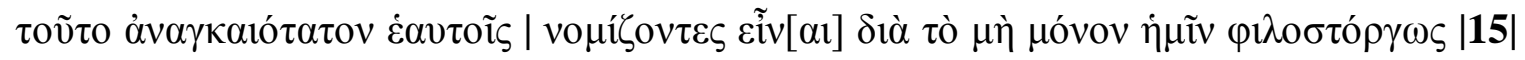

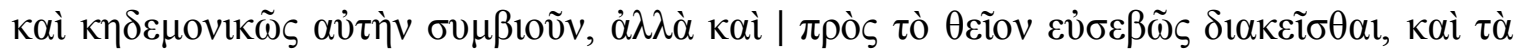

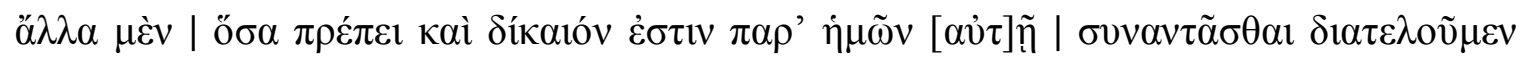
$\mu \varepsilon \tau \grave{\alpha}$

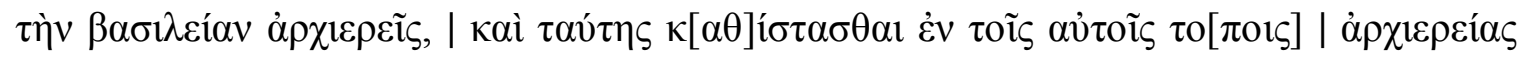

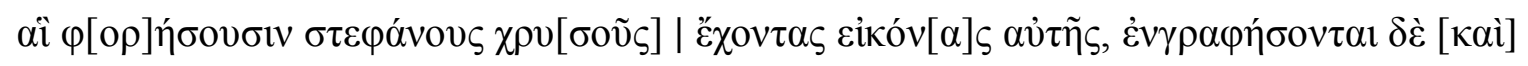

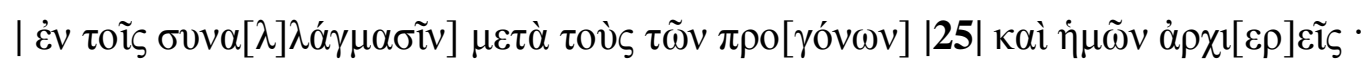

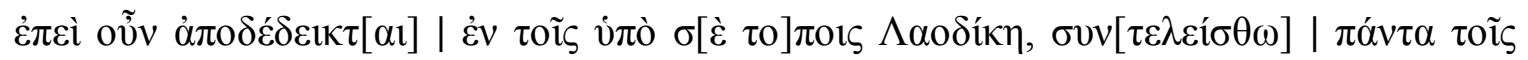

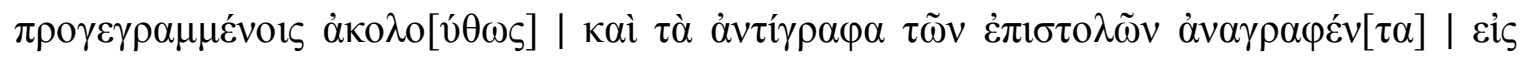

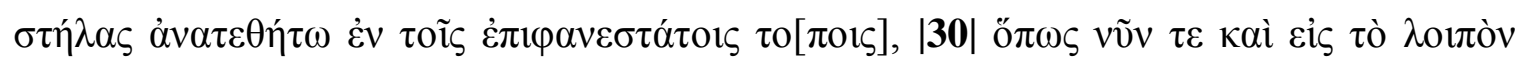

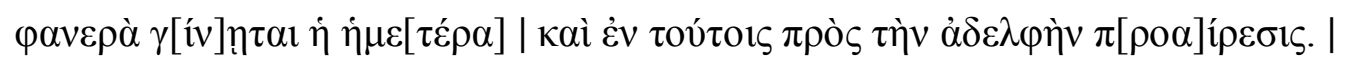

$\theta i \rho^{\prime} \Xi \alpha v[\delta 1 \kappa o \tilde{]}]$. 
Menedēmos, to Apollodōros \& the archons \& city of Laodikea, Greetings.

Attached is a copy of the prostagma written to us by the king, so follow these instructions and ensure that the command is written up on a stone stele and set up in the most prominent of the temples in the city.

Farewell. $10^{\text {th }}$ Panēmos, 119 SE [June/July 193 BC]

King Antiochos [III], to Menedēmos, Greetings.

Wishing to further increase the honours of our Sister-Queen Laodikē and considering this most important to us, not only because she lives affectionately and attentively in marriage with us, but also [because] she is piously disposed towards the divine. So we continue with affection the other things which seem fitting and just for her to receive from us and we judge that just as archpriests are appointed throughout the kingdom for us [i.e. the King], archpriestesses will be established in those places for her. [These archpriestesses] shall wear golden crowns and hold statues of her [Laodikē], and also they will be named in contracts after the archpriests of our ancestors and ourself.

So as Laodikē has been appointed to those places under you, let everything be as written above and let a copy of this letter be set up inscribed on a stele in the most prominent places so that now and hereafter our affection for our sister in these matters may be clear.

Xandikos, 119 SE [March/April 193 BC] 


\section{OGIS 222 : Klazomenai : 268-262 BC}

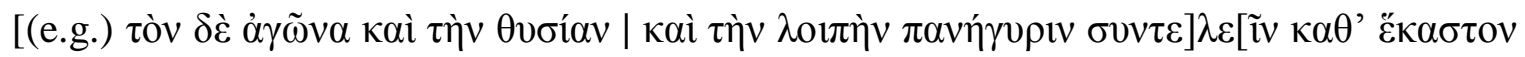

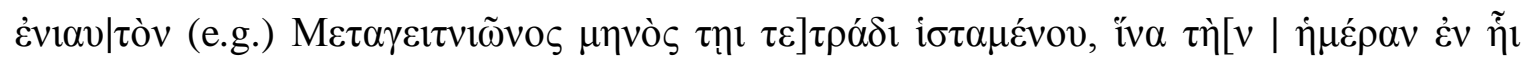

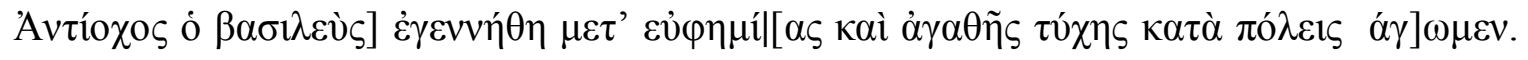

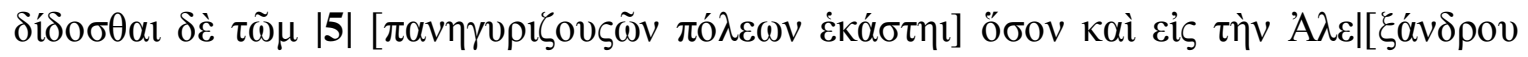

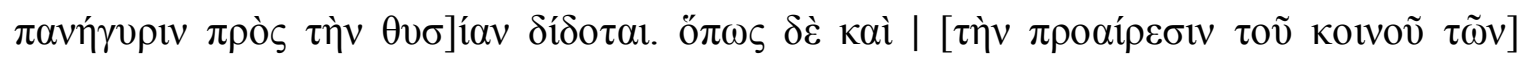

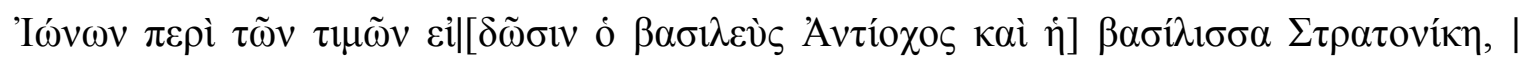

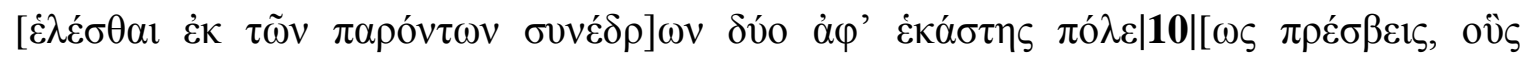

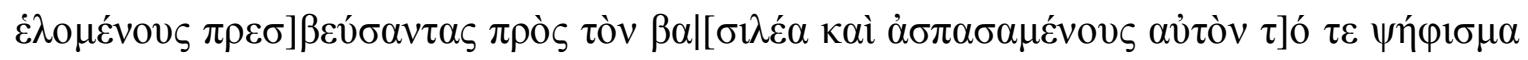

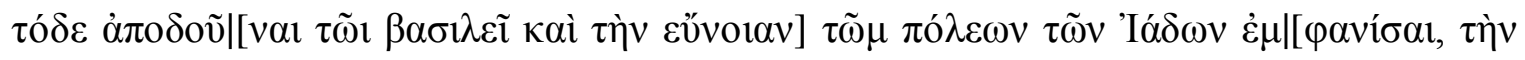

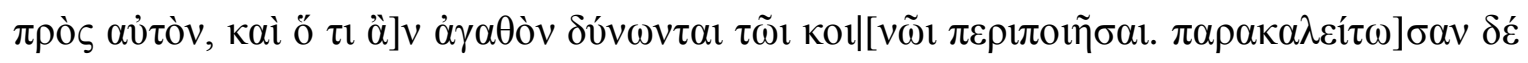

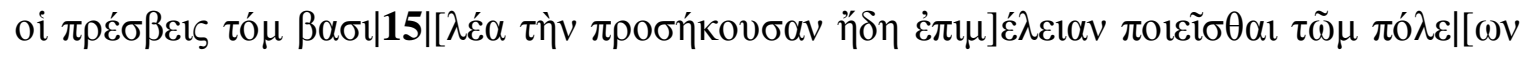

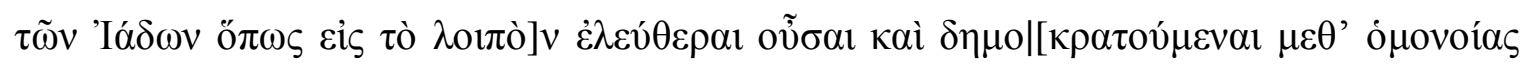

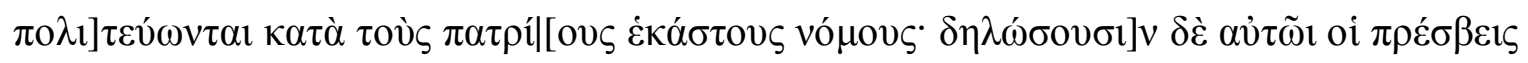

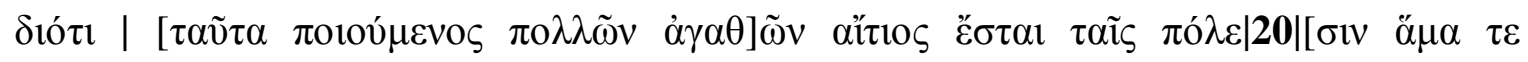

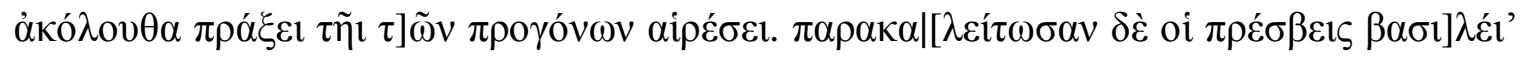

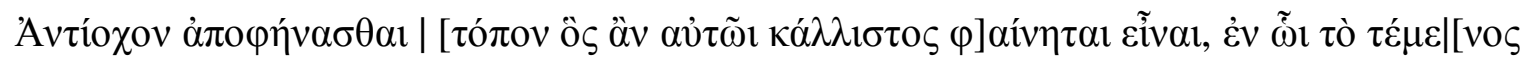

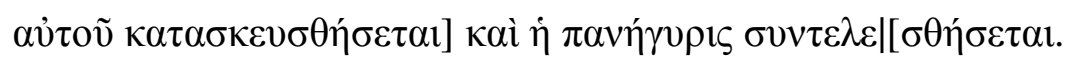

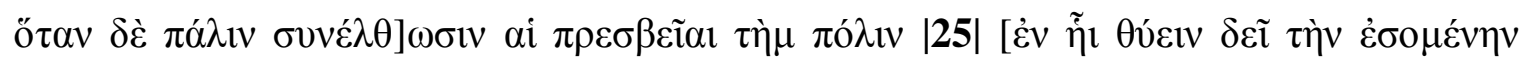

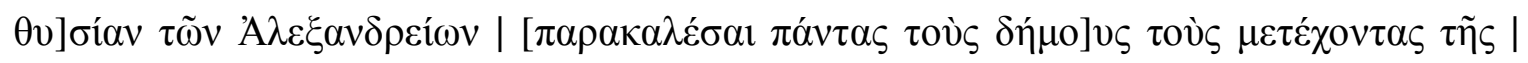

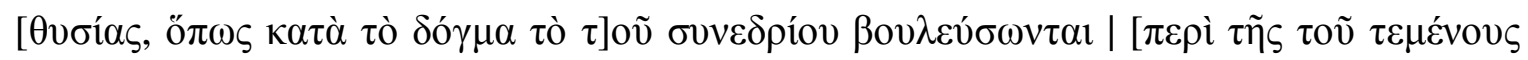

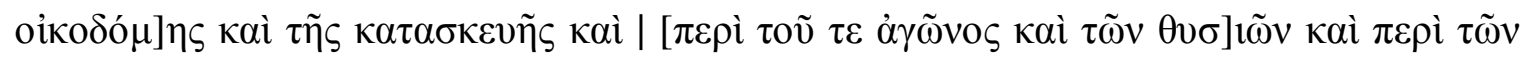

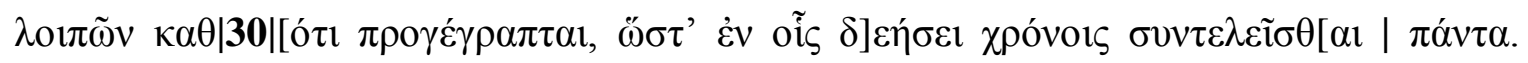

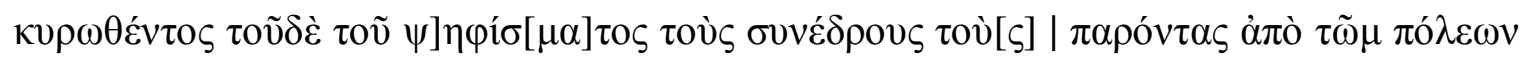

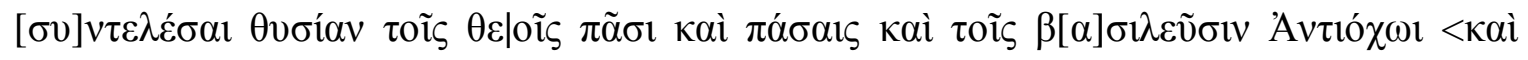

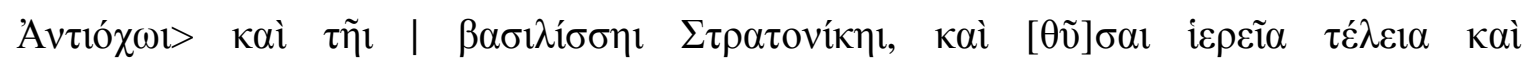

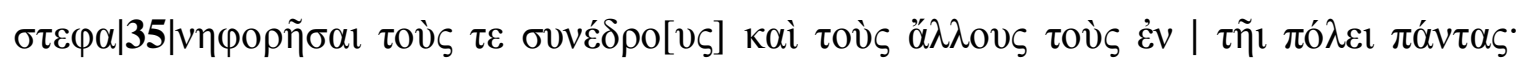

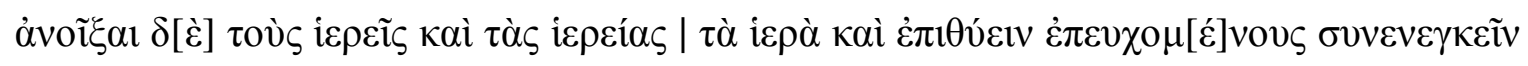

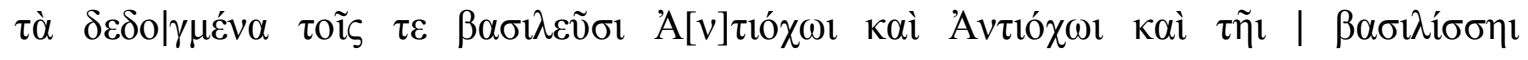

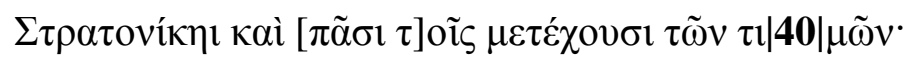

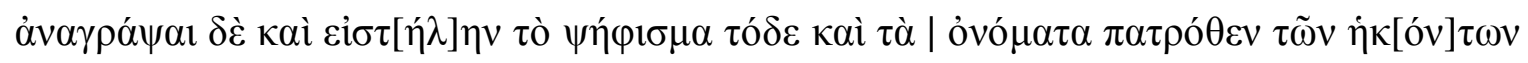

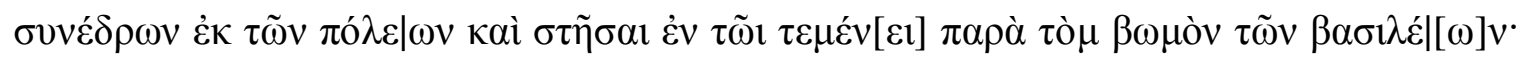

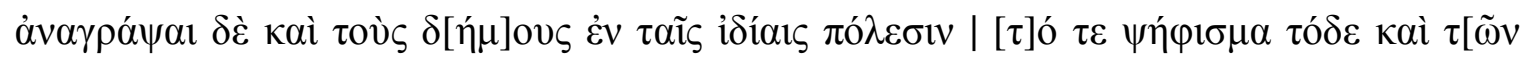

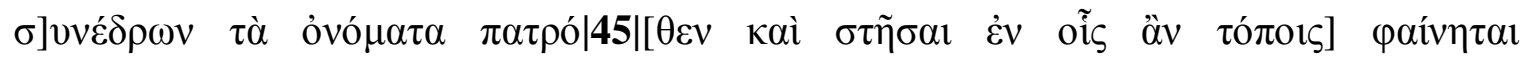

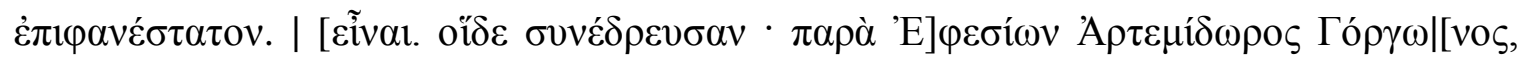
—— $16-\pi \alpha \rho \grave{\alpha} \Lambda \varepsilon] \beta \varepsilon \delta i ́ \omega v \cdot \mathrm{K} \alpha \dot{\pi}\left[\omega \varepsilon \dot{\alpha}{ }_{\varsigma} ?-\ldots\right.$ 
[e.g....it was resolved to h]ol[d games, sacrifices and other festivities each year as (e.g.) Metegeitniōn] comes to an end, on the [th]irtieth, in order that we might [celebrate] the [day on which King Antiochos I] was born with honou[r and good fortune throughout the poleis, and the same amount] is to be given [for the sacrifice to each of the poleis holding these festivities] as is given for the [festiv]al of Ale[xander]. And in order that [King Antiochos and] Queen Stratonikē shall know [the decree of the league of the] Ionians about the honours, two [envoys are to be selected out of those councillors who are present], from each polis [and the ones chosen are to go as envoys] to ki[ng Antiochos, to greet him and to] give this decree [to the king and to demonstrate the goodwill] of the poleis of the Violets [towards him] so that the envoys might be able [to gain] profit for the leagu[e of poleis]. And [let] the envoys [encourage] Kin[g Antiochos] to increase [the care already belonging] to the poleis [of the Violets in order that in all other matters] they, being free and demo[cratic], may be governed [in harmony] according to their ancestr[al laws. And] the envoys [will demonstrate] to him that, on account of [doing these things] he will be the cause [of many good things] for the poleis [and also that he would be acting consistently with the] policy of his ancestors. [Let the envoys] encourage King Antiochos to declare [the place, which] seems best to him, in which [his] sanctuary [may be built] and the fairground [may be] set up.

[And when] the embassies for the polis [meet again in the place where the next sacrifice] of the Alexandreia [is to be celebrated, they are to summon all of the demoi who participate in the [sacrifice, so that, in accordance with the decree] of the council, they may decide [about the construction of the sanctuary] and its provisioning and [about the games and sacrifice]s, etc. just [as written above, so that] it may be decided in which time everything will be carried out. When this decree [is ratified], the councillors who are present from the poleis are to celebrate the sacrifice for all the gods and goddesses and for King Antiochos < and King Antiochos II> and Queen Stratonikē, and to sacrifice perfect victims, and both the councillors and everyone else in the polis will wear crowns. And the priests and the priestesses are to open the temples and to sacrifice also, praying that the things decided benefit King Antiochos, King Antiochos and Queen Stratonikē and [all] those participating in these honours.

And also [they] will copy this decree and the names (with patronymics) of the councillors who came from the poleis onto a stele and set it in the sanctuary near the altar of the kings. And also the demoi in their own poleis will copy both this decree and the councillors' names (with patronymics) [and set them in whichever places] appear to be the most prominent. [These were the councillors: from the E]phesians: Artemidōros son of Gorg[ōn] _ _ _ _ f from the Lebedians: Kap[ōeus?] 


\section{OGIS 223 : Erythrai : 261-246 BC}

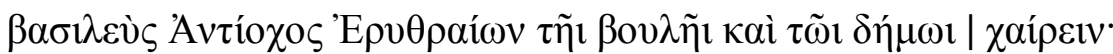

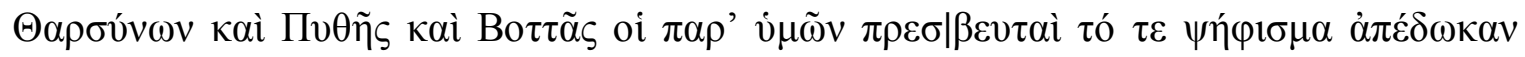

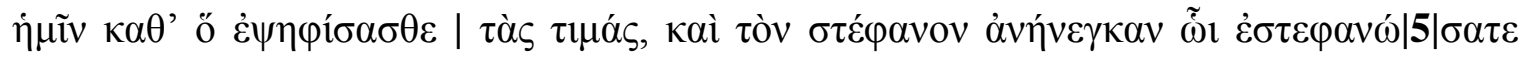

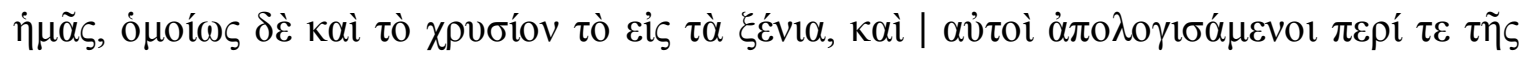

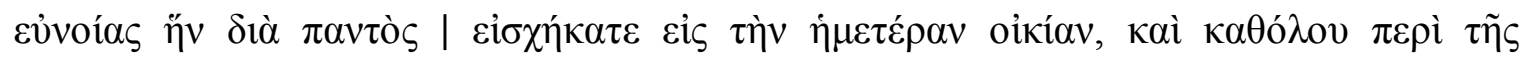

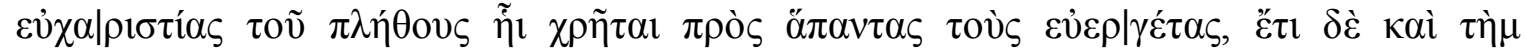

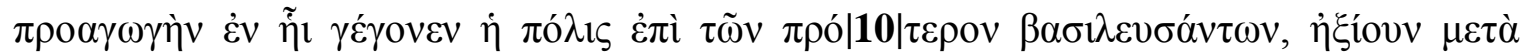

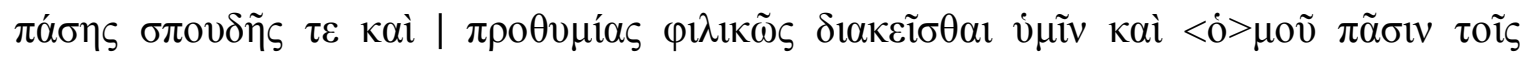

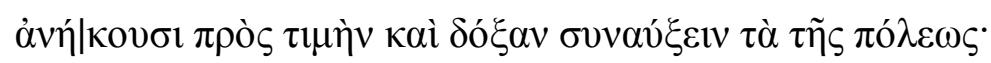

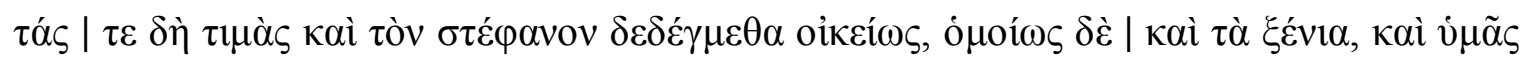

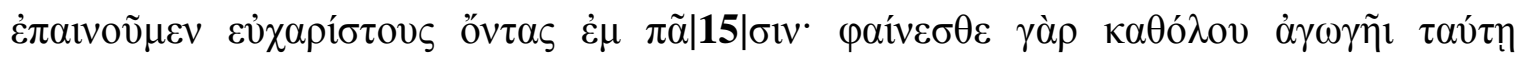

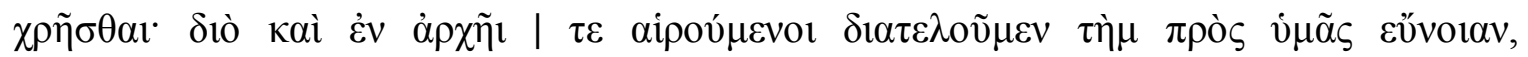

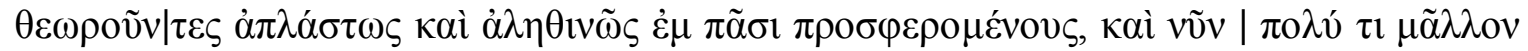

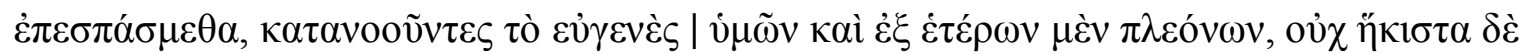

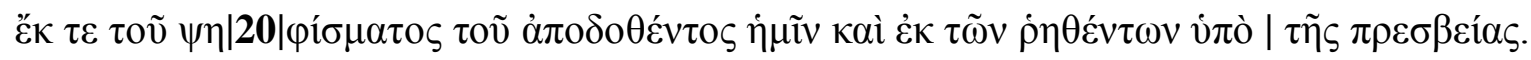

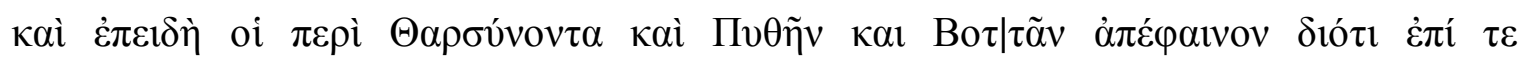

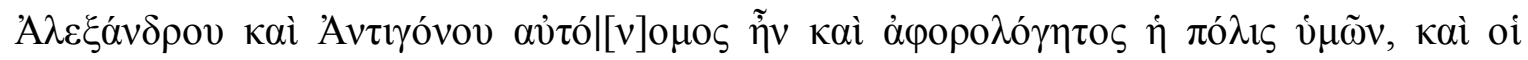

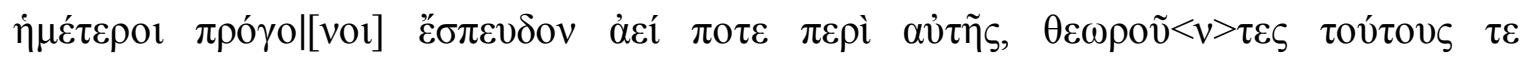

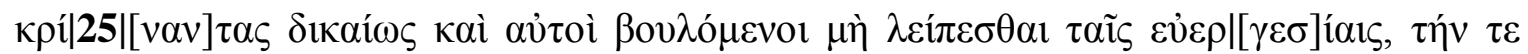

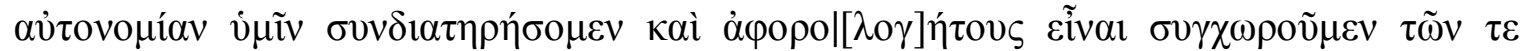

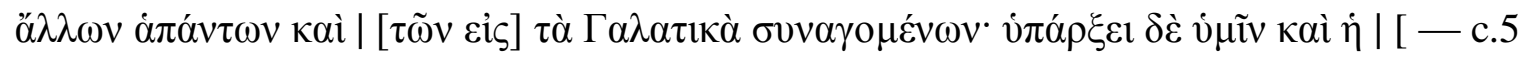
—

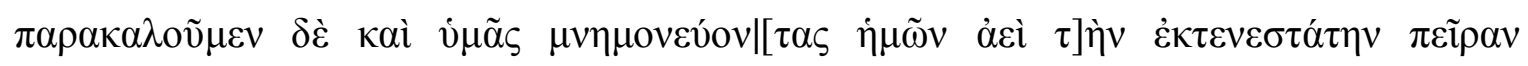

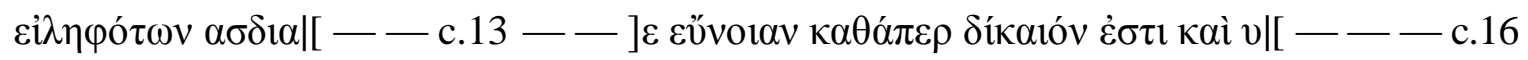

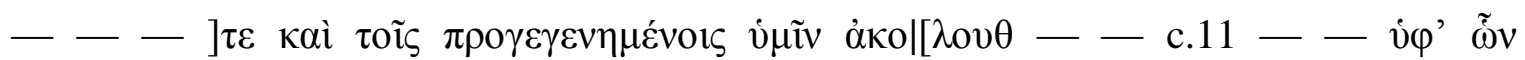

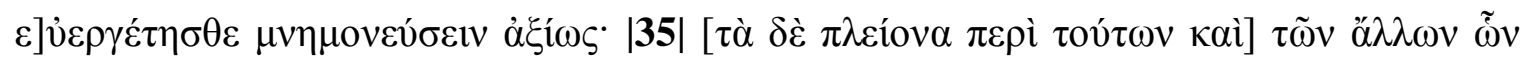

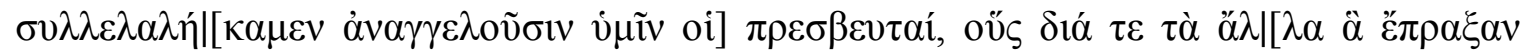

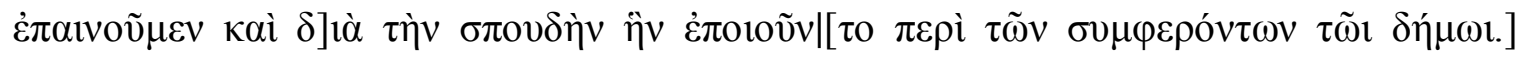
$\check{\varepsilon} \rho<\rho>\omega \sigma \theta \varepsilon$.

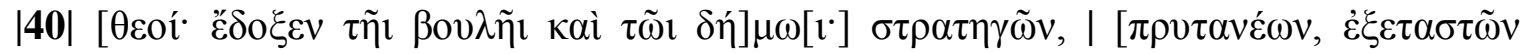

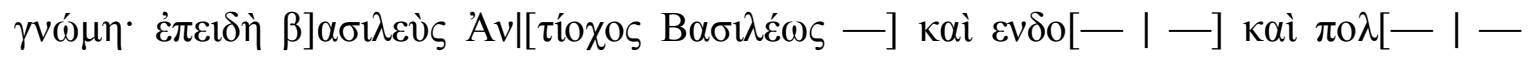
]$\pi \circ \lambda \varepsilon[-]$ 
King Antiochos [II] to the boulē \& dèmos of the Erythraians, greetings.

Tharsynōn, Pythēs, and Bottas, your envoys, delivered your decree to us according to which you voted honours [for us] and they brought the crown with which you crowned us, and likewise also, the friendly gift and they gave an account of the honours which you have extended to our house through everything and about the gratitude of the masses in general, which is proclaimed for all our good deeds, and further also the prosperity which the polis came into under the previous rulers, they asked with all fervour and enthusiasm that [we] be friendlily disposed to you and also to all those to whom belong honour and glory for increasing the affairs of the polis.

We have indeed accepted the honour and the crown, as is proper, and likewise also the friendly gift and we applaud your gratitude in regards to everything - for you clearly act this way always. And therefore, we continue holding goodwill towards you, [as we have since] the beginning, observing that you contribute unaffectedly and genuinely in everything, and we are encouraged now more than ever, recognising your nobility also from many different things, but not least from the decree delivered to us and the things said by your embassy. Since those with Tharsynōn, Pythēs, and Bottas demonstrated that your polis was autonomos and free from tribute under Alexander and Antigonos, and that our ancestors always pursued this, we, recognising that these things were justly decided and also wishing not to cease from our good deeds, will carefully guard your autonomia and we agree for you to be exempt from all the other tributes and from the anti-Gallic levies. There will be for you also, the [ _ — - and ] any other benefaction we think of or you ask for. We encourage your persistent mindfulness of us, which we have always

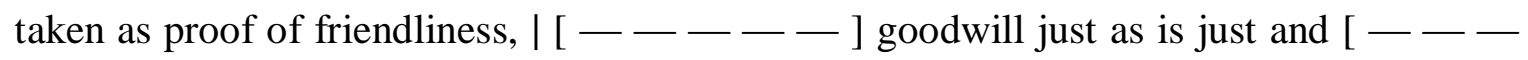
_ _ _ _ ] also for our ancestors [and we encourage you to continue?] to remember suitably those by whom you have benefitted. And the envoys, whom we praise for the other things which they did and for the devotion which they have for the profit of their dèmos, will inform to you about these matters and the other things which we have settled. Farewell.

[O gods! The proposal of] the stratēgoi, [pytaneis and exetastai seemed good to the boule and the dèmos]: Since K]ing Antiochos, son of King _ _ _ _ _ 


\section{OGIS 225 : Didyma, Milētos : 253 BC}

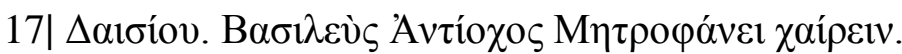

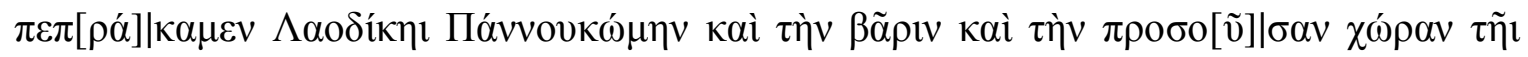
$\kappa \omega ́ \mu \eta$

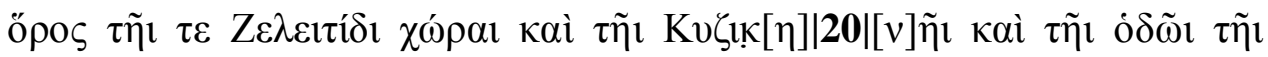

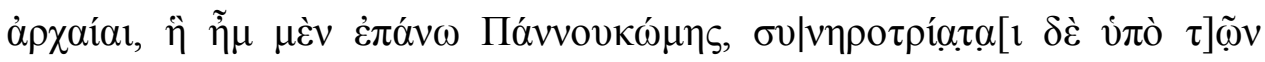

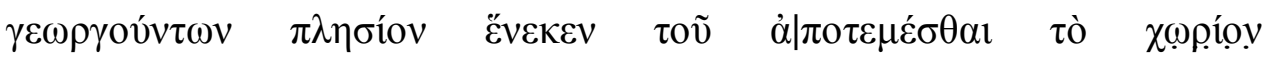

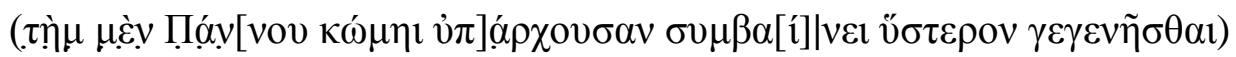

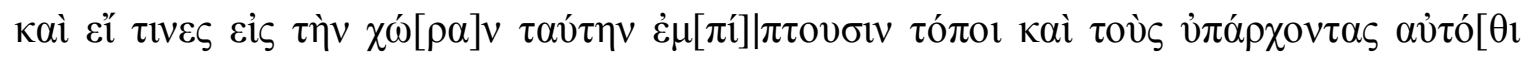

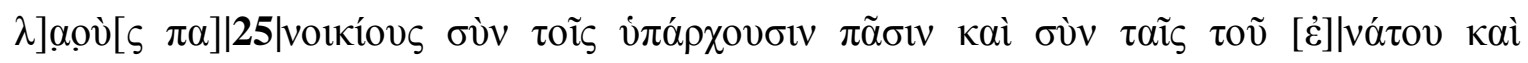

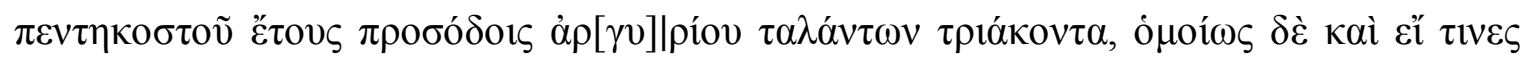

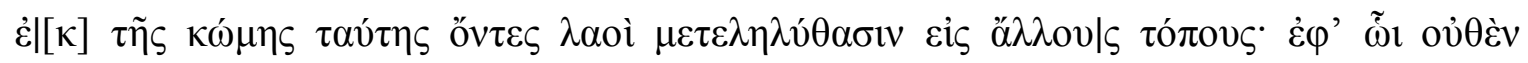

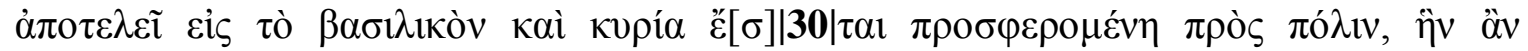

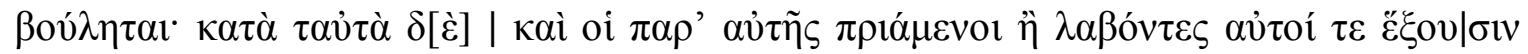

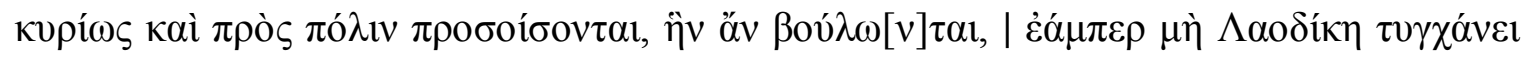

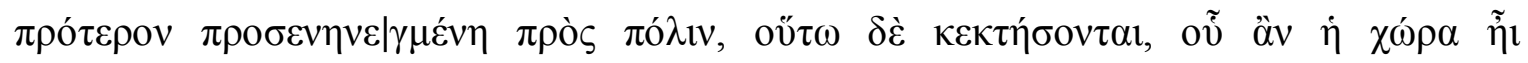

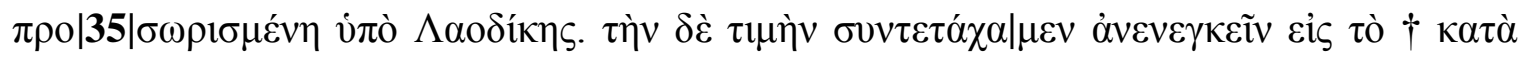

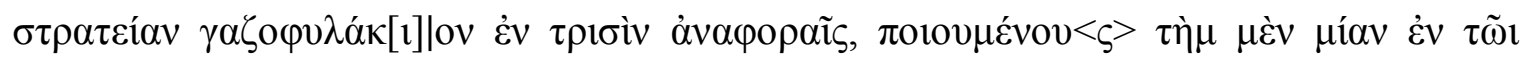

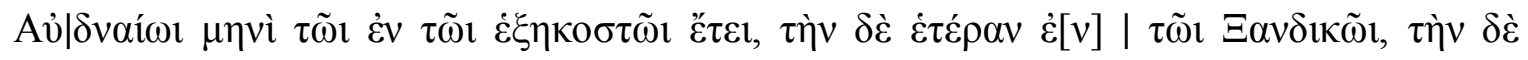

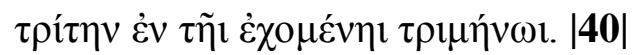

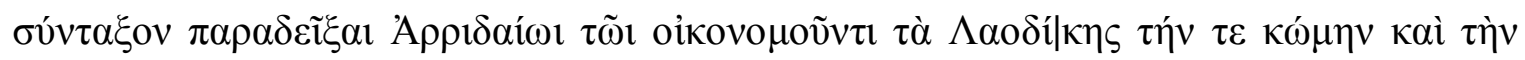

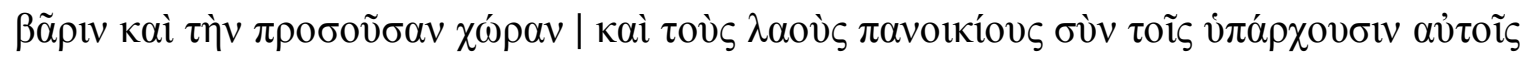

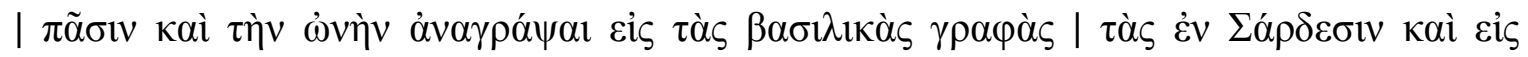

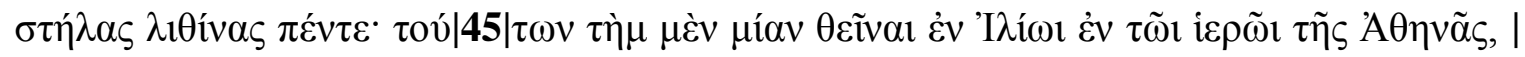

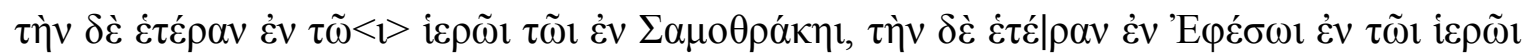

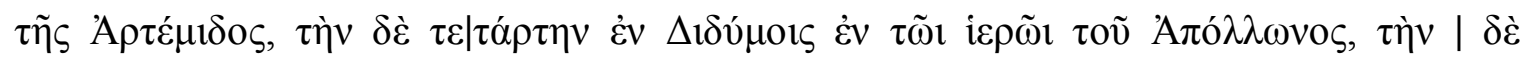

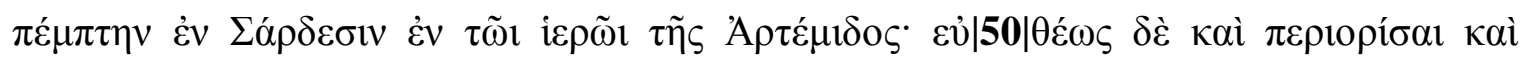

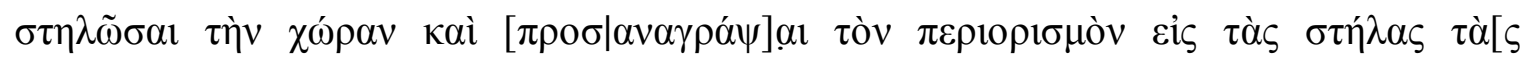

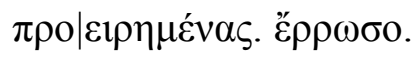

$\left[v \theta^{\prime}\right] \Delta$ íov $\varepsilon^{\prime}$ 
Daisios. King Antiochos [II] to Mētrophanēs, greetings.

We have sold to Laodikē: Pannoukōmē, the manor and the land around it:

Boundary: the Zeleitian land, the Kyzikēne land, the old road, which was above Pannoukōmē, but was plowed up by the neighbouring farmers together in order to appropriate the land (the current road to Pannoukōmē was made later)

And any places that fall within this land and any household serfs who possess [land] in that place, with all their possessions and with the incomes of the fiftieth-ninth year [254 $\mathrm{BC}$ ], for thirty talents of silver. Likewise, any commoners from this village who have migrated to other places. From it she will pay nothing to the royal treasury and she will be authorised to convey [the land] to a polis, whichever she wishes. And in the same way, those who buy or receive the land will have the same authority and will convey the land to a polis, whichever they wish, except if Laodikē happens to have already conveyed it to a polis, thus they will get the land which has been surveyed for Laodikē. And we have arranged to pay the price to the gazophylakion in the service in three payments, the first in Audanios in the sixtieth year [253 BC], the next in Xandikos, the third in the following three months.

Organise to hand over to Arrhidaios the oikonomos of Laodike's property: the village, the manor, the land around it, and the household serfs with all their possessions and to record the sale in the royal ledger in Sardis and on five stone steles. Of these, set up the first in Ilion in the temple of Athena, the next in Samothrakē, the next in Ephesos in the temple of Artemis, the fourth in Didyma in the temple of Apollo, the fifth in Sardis in the temple of Artemis. And quickly mark out the land and set up boundary stones and record the boundary on the [aforementioned] steles. [Farewell].

[Year $59[253 \mathrm{BC}]] 5^{\text {th }}$ Dios 


\section{OGIS 233 : Magnēsia-on-the-Maiandros : 193 BC (Part one)}

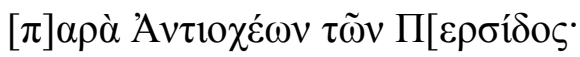

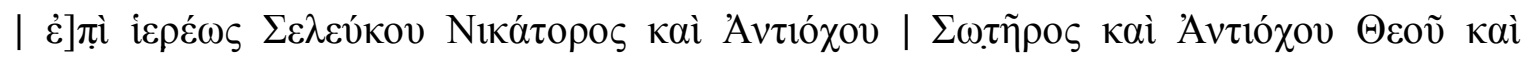

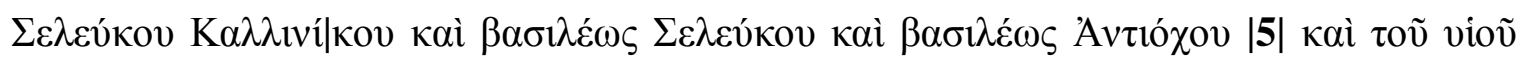

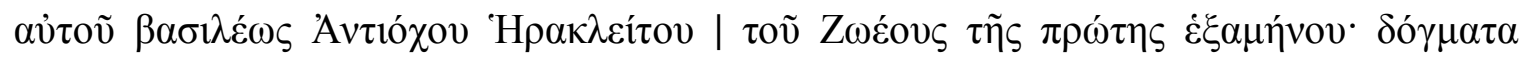

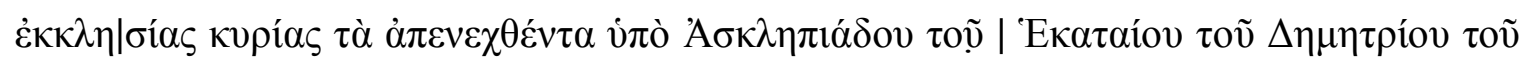

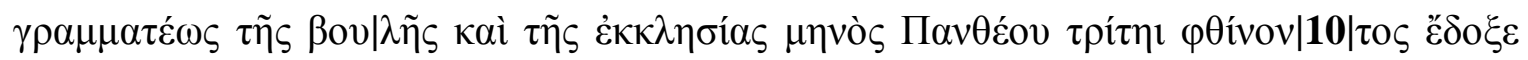

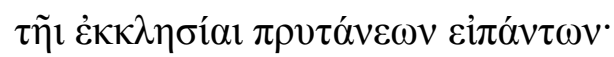

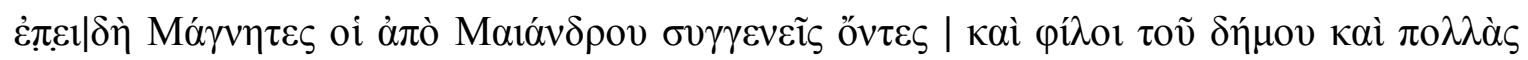

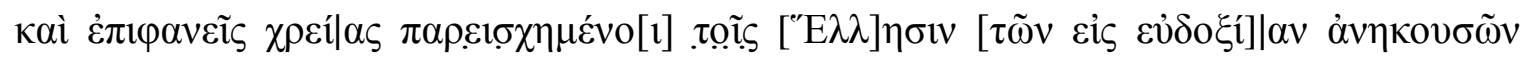

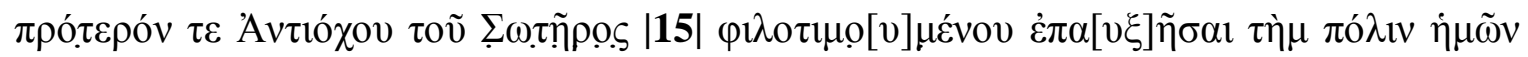

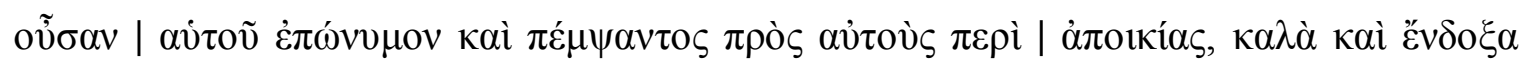

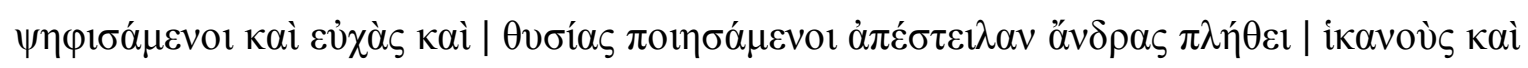

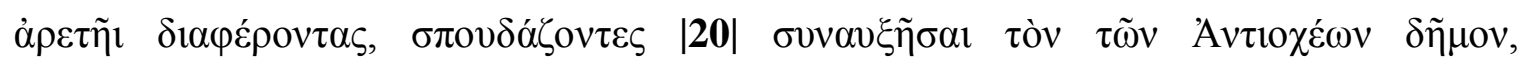

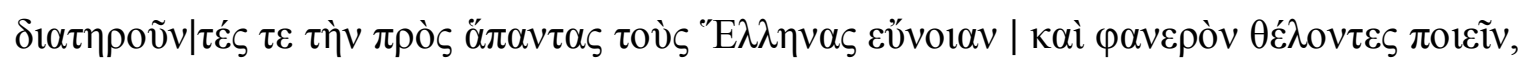

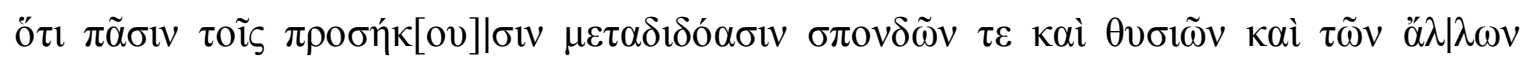

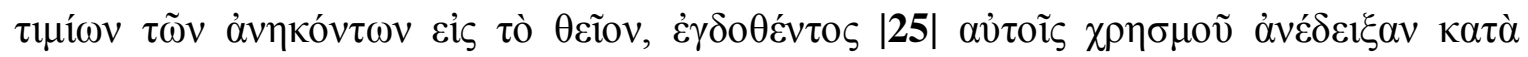

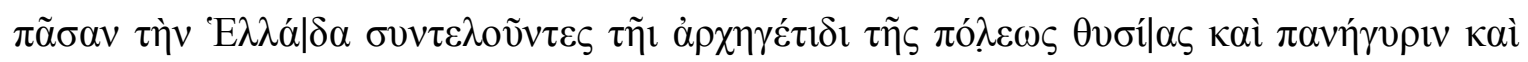

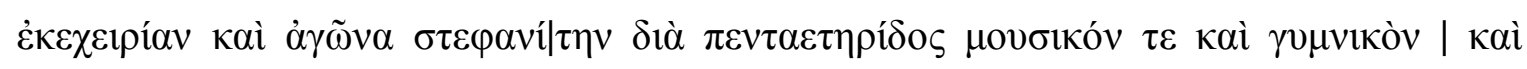

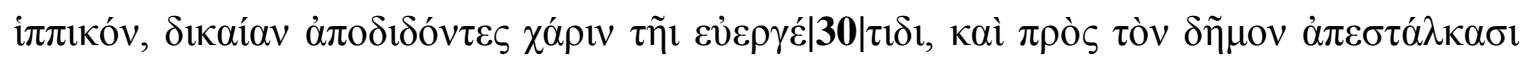

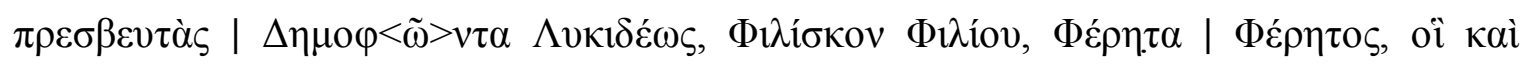

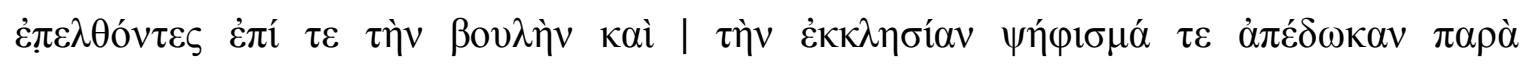

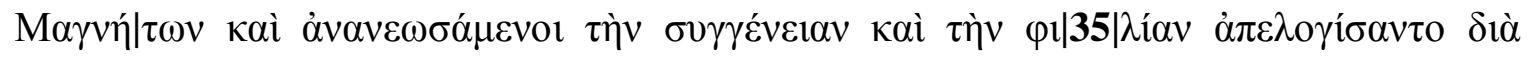

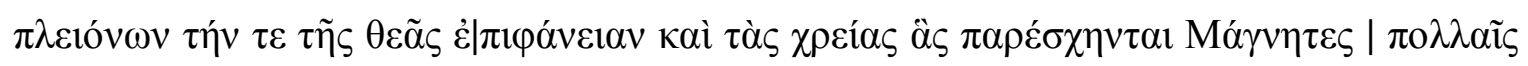

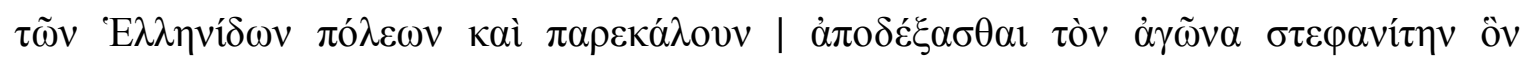

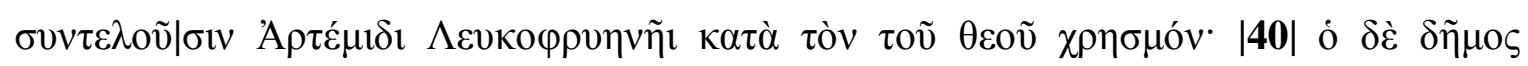

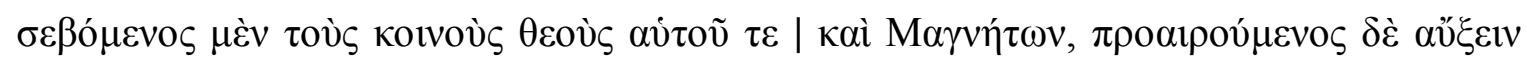

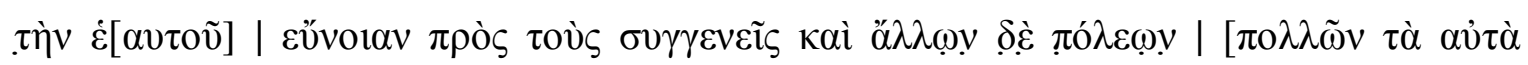

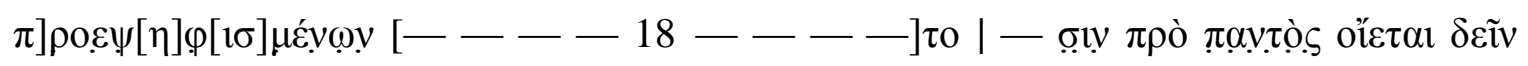

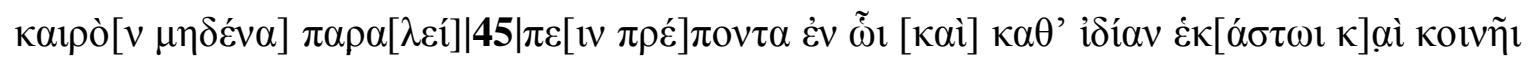

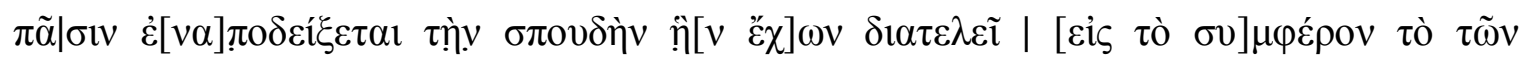

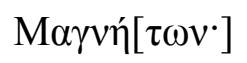


From the Antiochenes of Persia.

In the first six months of Hērakleitos son of Zōeos' [tenure as] priest of Seleukos [I] Nikatōr, Antiochos [I] Sōtēr, Antiochos [II] Theos, Seleukos [III] Kallinikos, King Antiochos [III] and his son King Antiochos, decrees of the sovereign assembly were affirmed under Asklēpiadēs son of Hekataios son of Dēmētrios, the secretary of the council and assembly in the latter third of the month of Pantheos, that seemed good to the assembly, when the prytaneis had said:

Since the Magnēsians on the Maiandros are kin and friends of the dēmos, and have also provided many conspicuous services to the Greeks, they are among those who have risen to glory, and, formerly [in the time of] honour-loving Antiochos [I] Sōtēr, our polis (which was named after him) was to be enlarged, and when he contacted them about colonisation, they voted good and glorious things, made prayers and sacrifices sent men who were ample in number and lived with excellence, as they were eager to join in increasing the dèmos of the Antiochenes. They maintain goodwill towards all the Greeks and wish to make it clear that they give all their relations a share of libations, sacrifices, and other honours which reach up to the divine, which they proved to all Greece when gold was donated to them, by celebrating sacrifices, festivities, a holiday, and quinquennial crown games in arts, athletics, and horsemanship for the foundress of their polis, giving just gratitude to their benefactrix, and dispatched these ambassadors to our dēmos: Dēmoph $<\overline{\mathrm{O}}>$ n son of Lykideus, Philiskos son of Philios, and Pherēs son of Pherēs, who addressed the council and Assembly and delivered the decree of the Magnēsians. After renewing our kinship and friendship, they gave an account for most of their time of the manifestation of the goddess and the services which the Magnēsians provided to many of the Greek poleis and encouraged us to acknowledge the crown games, which they celebrate for Artemis Leukophryēnē according the oracle of the god. And since the dèmos worships the gods shared by them and the Magnēsians, and wishes to increase their goodwill to their kin, and many other poleis having voted the same things _ _ _ — — _ - for all, it thinks it must be right [not] to waste an opportunity in which to show the gratitude which it has held all along for the gift of the Magnēsians, for each of them individually and all of them in common. 


\section{OGIS 233 : Magnēsia-on-the-Maiandros : 193 BC (Part two)}

$\dot{\alpha} \gamma \alpha \theta \tilde{\eta} \iota \tau \hat{\chi} \chi ̣[1$.

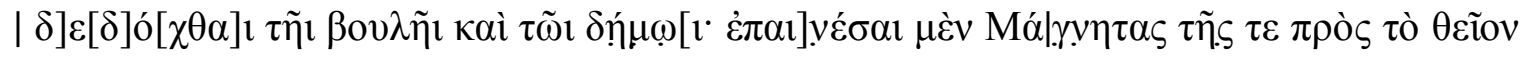

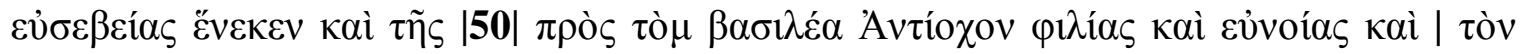

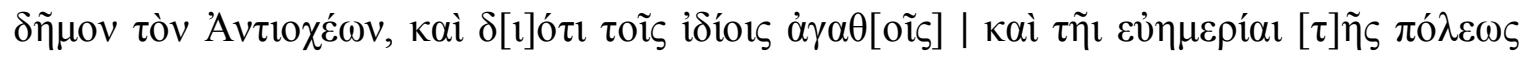

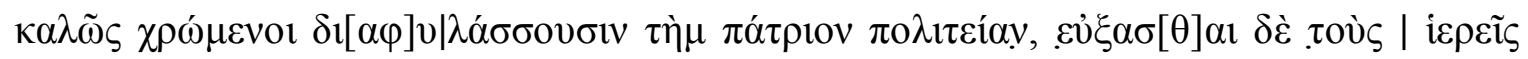

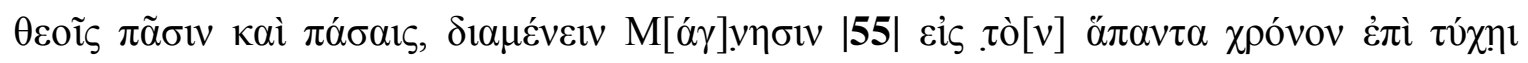

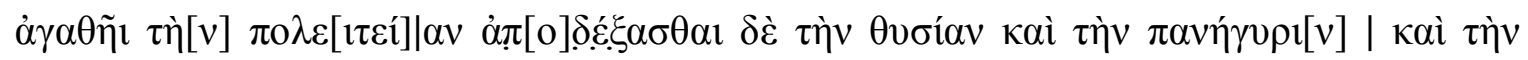

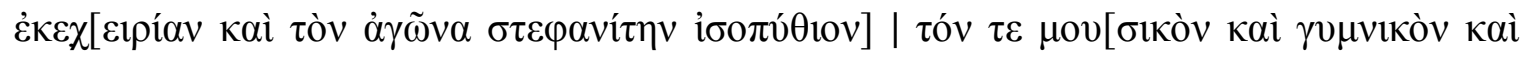

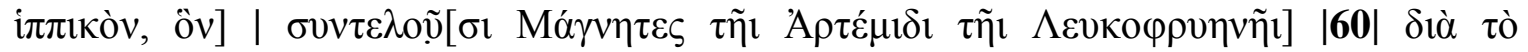

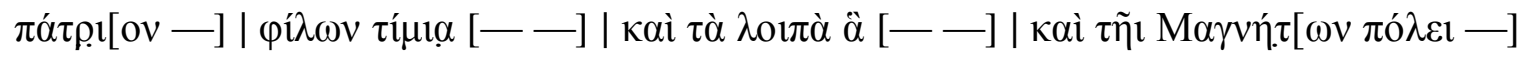

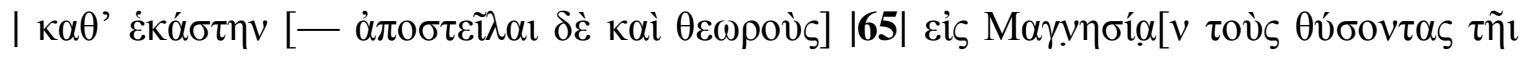

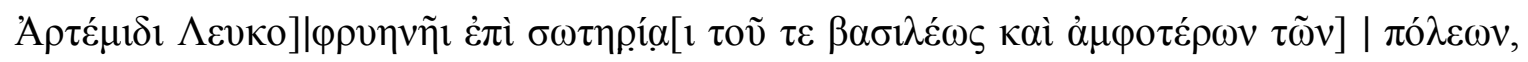

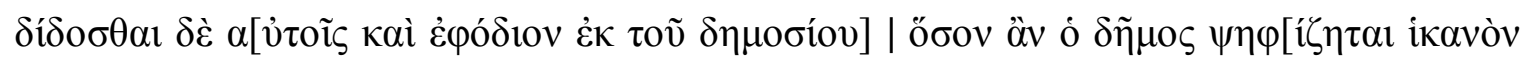

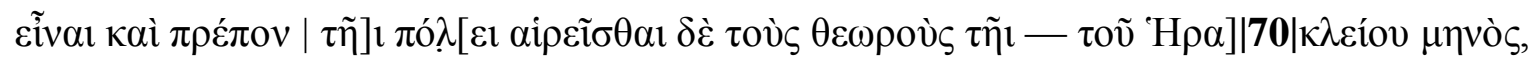

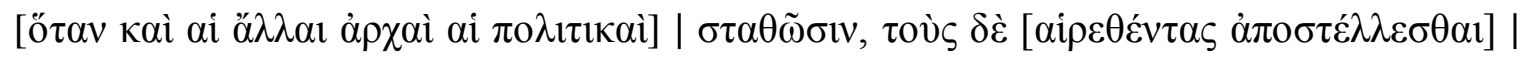

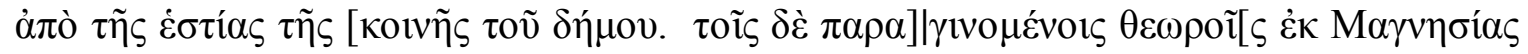

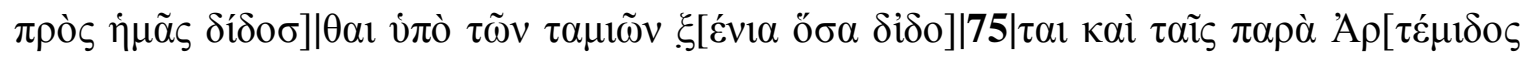

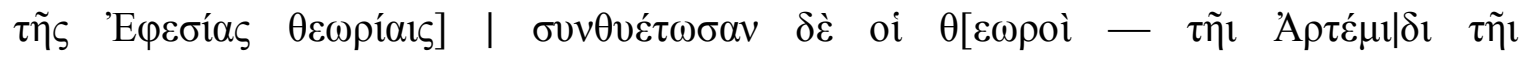

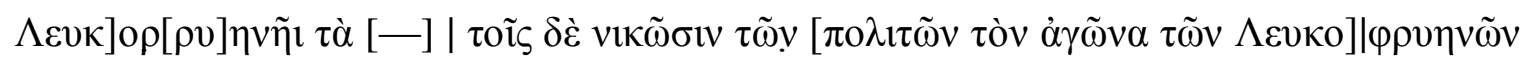

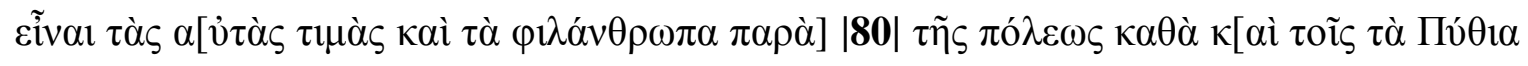

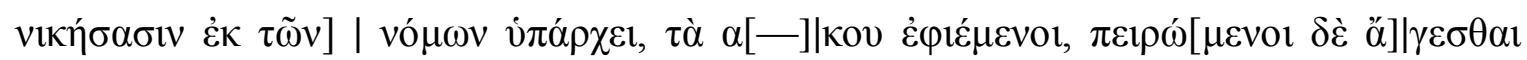

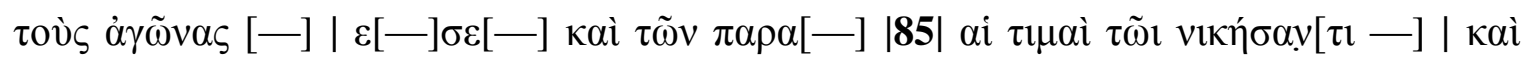

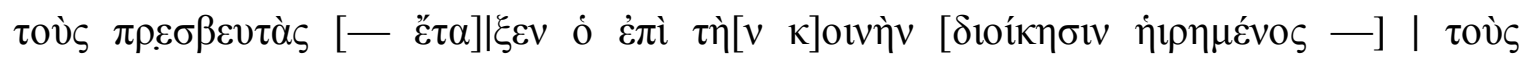

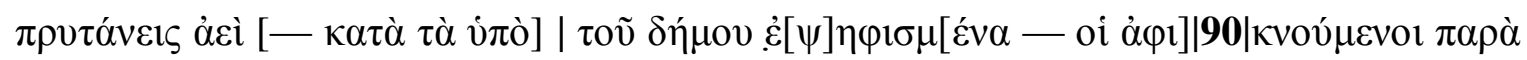

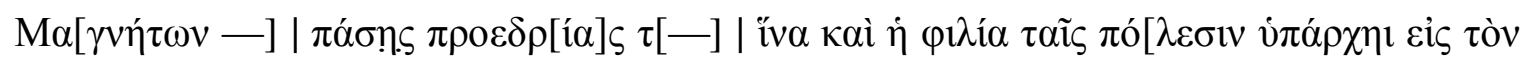

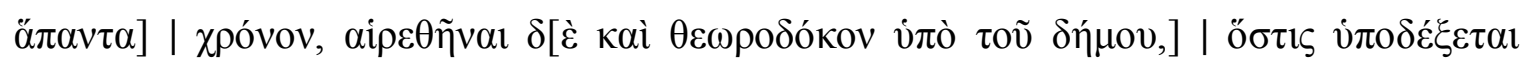

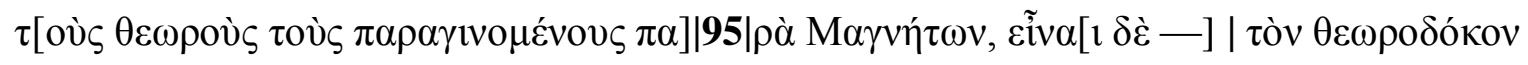

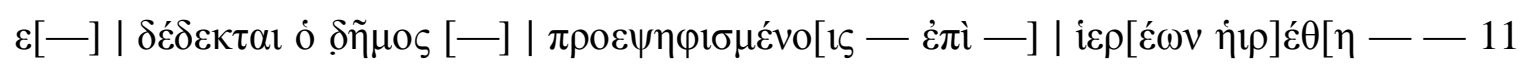
—— $\mathrm{H} \gamma] \eta \emptyset \underline{\alpha} \alpha \underline{v}[\delta \rho o y]$.

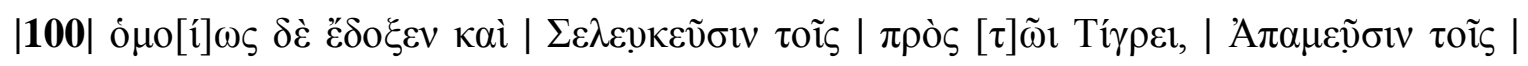

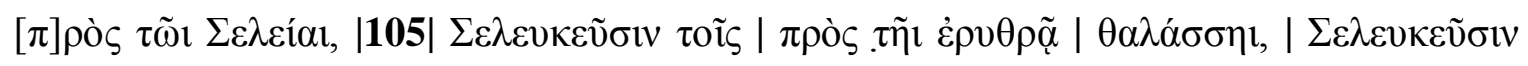

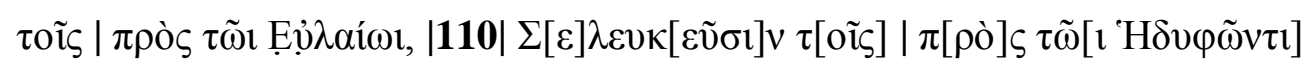




\section{Good Fortune!}

It has been resolved by the boule and the demos:

- to honour the Magnēsians on account of their piety to the divine, on account of their friendship and goodwill towards King Antiochos and the dèmos of Antiochenes, and because they have acted well for the private good and the prosperity of the polis, maintaining the ancestral constitution.

- That the priests are to pray to all the gods and goddesses, that the Magnēsian state persist in good fortune for all time

- To recognise the sacrifices, festivities, holiday, and the Pythian-grade crown games in $\operatorname{ar}[\mathrm{ts}$, athletics and horsemanship, which] the Magnēsians celebrat[e for Artemis Leukophryēnē], because of the ancestral —, honour of friends — etc., which — and to the Magnēsian polis - for each -

- [And to send theōroi] to Magnēsia, [to sacrifice to Artemis Leuko]phryēnē for the salvation [of the king and of both] poleis, and also to give them a travel allowance from the public funds, however much the demos dec[rees to be sufficient and appropriate fo]r the po[lis. And the theōroi are to be chosen on - of the month of Hērakleios [when the other public magistrates] are appointed, and those [chosen are to be sent] from the [common] hearth [of the dèmos].

- And a guest-gift is to be [given] to the theōroi who came [from Magnēsia to us], by the treasurers o[f the public funds, such as is giv]en to the [theōroi of Artemis of the Ephesians]. And let the th[eōroi sacrifice with us - to Artemis Leukophryēnē -

- And for those among [our citizens] who win [at the games of Leuko]phryēnē, there will be the s[ame honours and benefactions from] the polis as there are by custom [for the victors at the Pythian games],

- allowing, attempting to win the games — and of those near — the honours for the victor — and the one [appointed over] the common [treasury] arranged the ambassadors — the prytaneis always [ - according to the things] decreed by the demos — those arriving from the $\mathrm{Ma}$ [gnēsians - - ] front-seat-priviliges in everything — so that also the friendship of the poleis [might continue for all] time, and also [a theörodokos is] to be chosen [by the dēmos], who will billet the theōroi who came fr]om Magnēsia, and the theōrodokos is to be — — the demos has received — by decrees — having been chosen from the priests $[-\ldots 11-$ Hēg]ēsan[dros - ]

And it likewise seemed good also to: the Seleukeians by the Tigris, the Apameians by the Seleia, the Seleukeians by the Red Sea, the Seleukeians by the Eulaios [Susa], the Seleukeians by th[e Hēdyphōn.... 


\section{OGIS 253 : Mesopotamia : $166 \mathrm{BC}$}

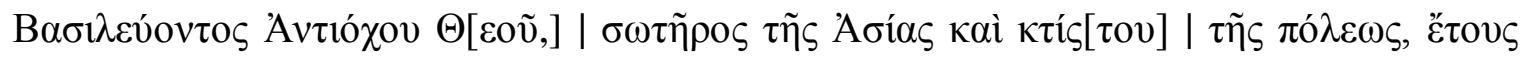

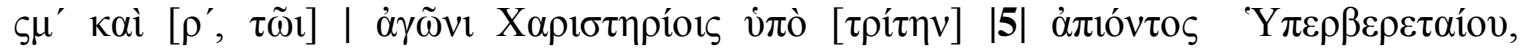

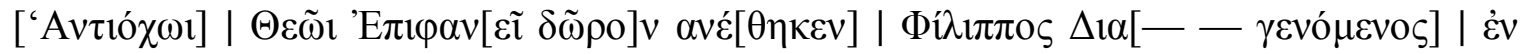

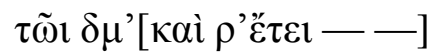

When Antiochos [IV] the G[od], saviour of Asia and foun[der] of this city was king, in the year [1]46 (i.e. 166/7 BC) at the Thanksgiving Games running from the 3rd of Hyperberetaios, Philippos son of Dia.... consecrated a gift to [Antiochos] the God Manifest [having been — — ] In [the year 1]44 — -

OGIS 254 : Mesopotamia : ????

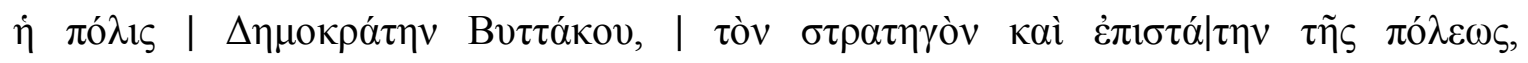

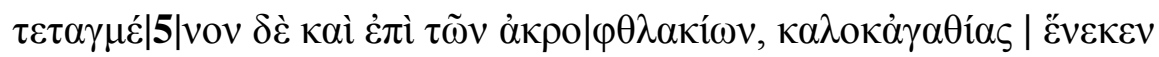

The polis [honours] Demokratēs (son) of Byttakos, the stratēgos and epistatēs of the polis, appointed also over the citadel guards, on account of his general excellence 


\section{OGIS 257 : Seleukeia-in-Pieria: 109 BC}

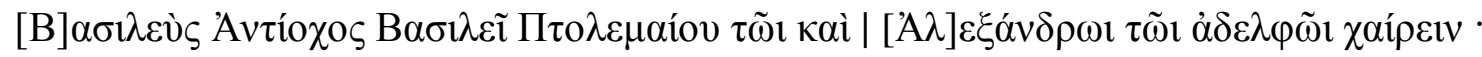

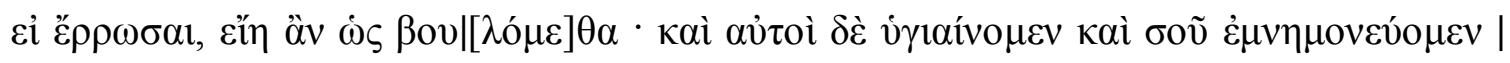
[

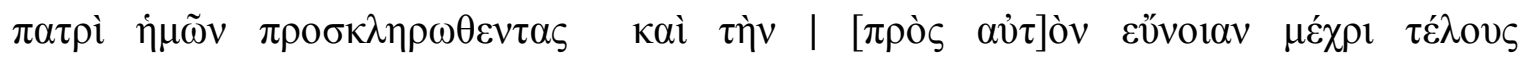

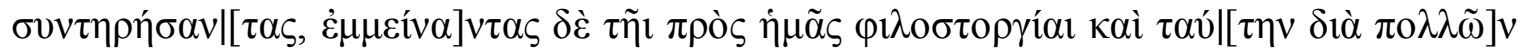

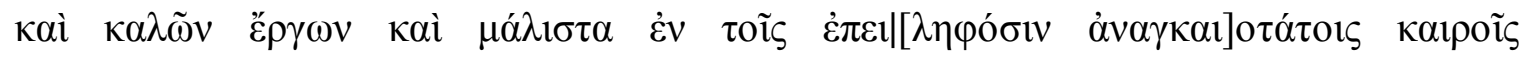

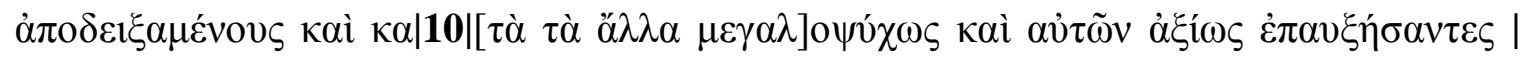

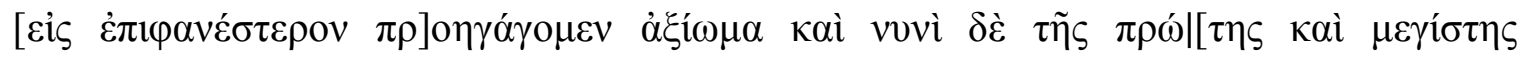

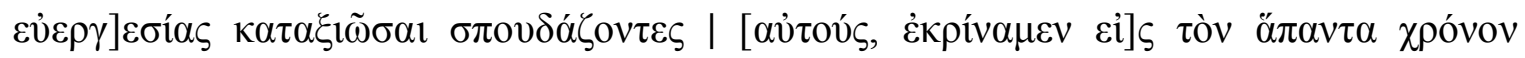

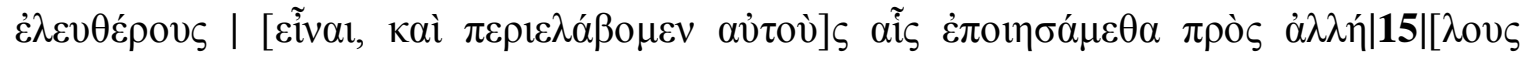

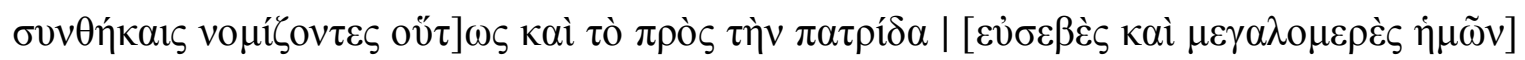

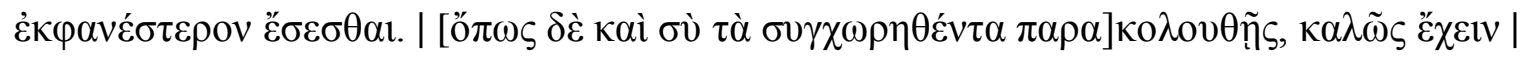

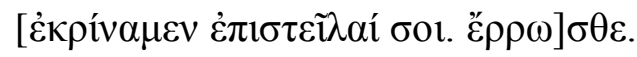

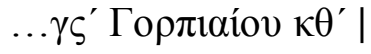

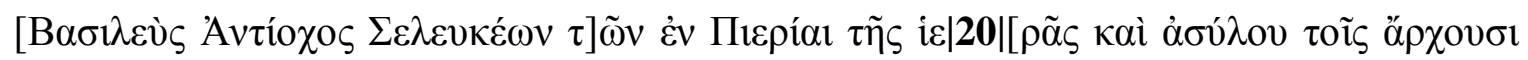

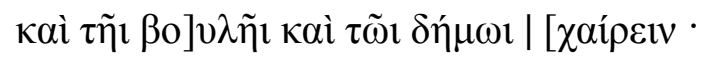

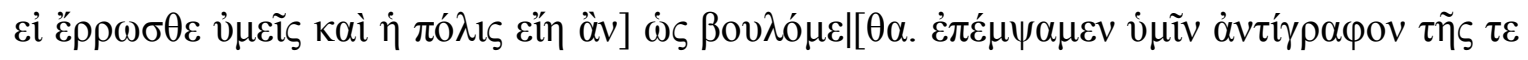

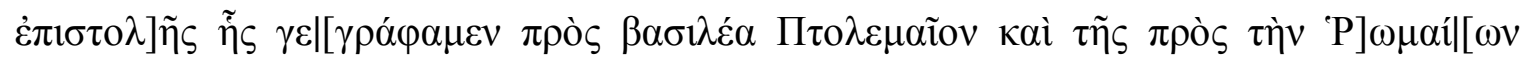

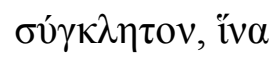
$\pi \alpha \rho \alpha] \kappa \circ \lambda \circ 0|25|[\theta \tilde{\eta} \tau \varepsilon$

[K]ing Antiochos to King Ptolemaios [IX], and to Alexandros [X], his brother, greetings.

If you are well then things are as we w[is]h. And likewise, we are in good health and have been thinking of you with [affect]tion. The Seleukeians-in-Pieria, holy and inviolate [since long ago], were attached to our father and retained their goodwill [towards hi] $\mathrm{m}$ to the end, [and they maintain]ed their affection towards us and showed th[is through many] good deeds and especially in those most [desperate] times [which have overtaken us], and in other matters we have supported them, as they deserve, and raised their reputation [to greater heights]. And now, eager to deem [them] worthy of the fore[most and greatest benef]icence, we have declared them to be free for all time, [and we have included them in the treaties] which we have made with each [other, thinking that our piety and magnificence] for our fatherland would be more clearly demonstrated [thereby. And in order that you, too], might kn[ow of these grants, we judged it appropriate to write to you. Farew]ell

Year 203 [109 BC], 29th Gorpiaios

[King Antiochos to the archons, bo]ule and demmos [of the Seleukeians] in Pieria, ho[ly and inviolate, Greetings!

If you and the city are well, it is] as we wish. [We send to you a copy of both the lette]r, which we have [written to King Ptolemaios and to the senate of the R]oma[ns, in order that you might know. 


\section{OGIS 339 : Sestos : 133-120 BC (Part One)}

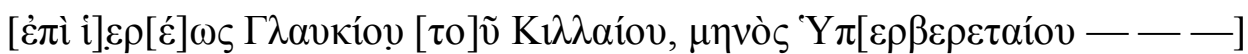

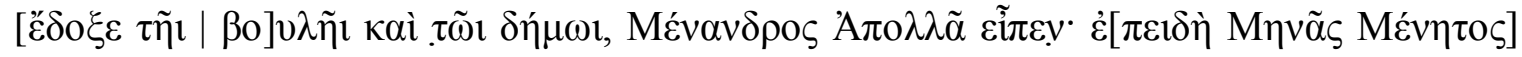

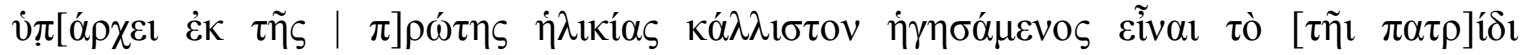

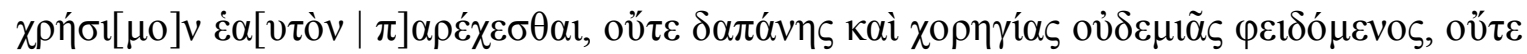

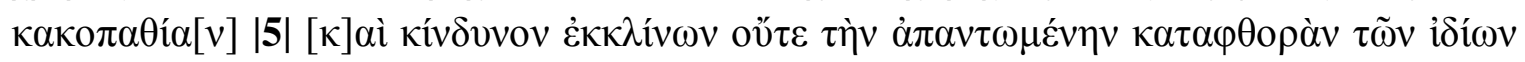

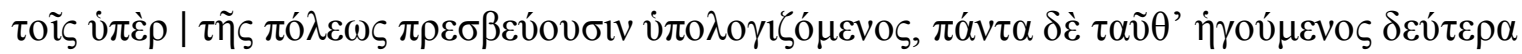

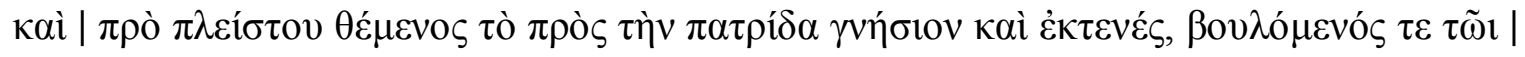

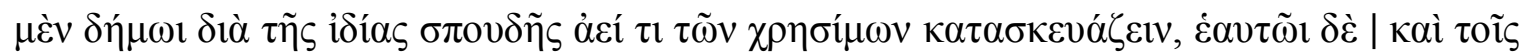

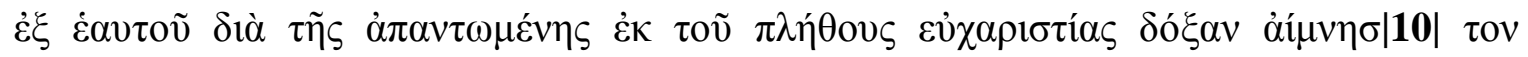
$\pi \varepsilon \rho 1 \pi \circ \varepsilon \tilde{i v}$,

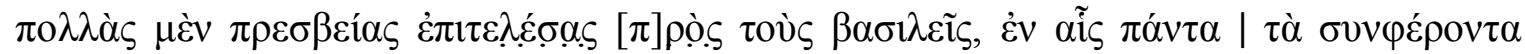

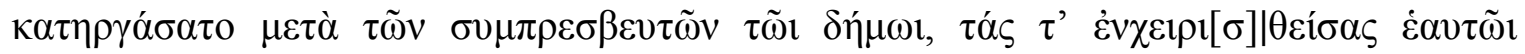

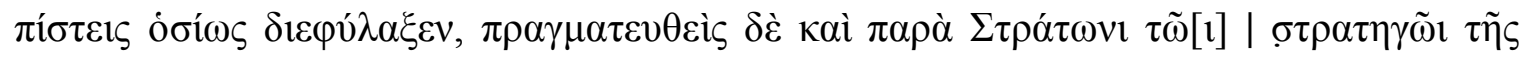

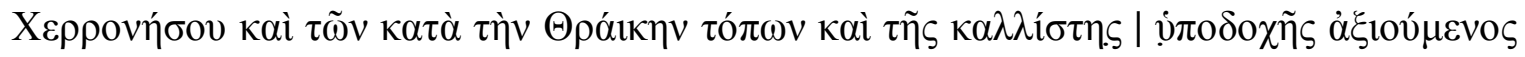

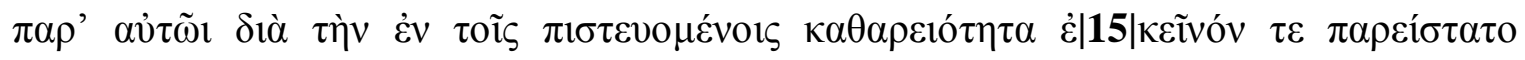

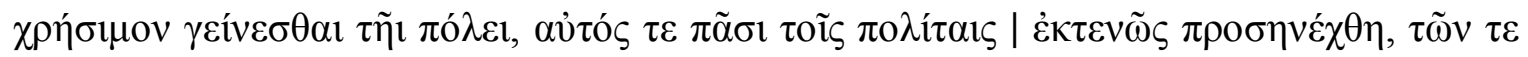

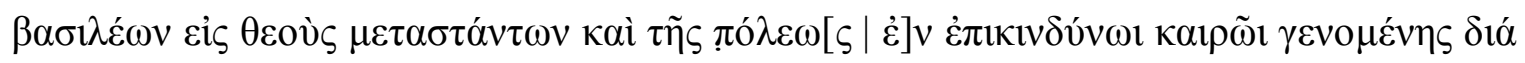

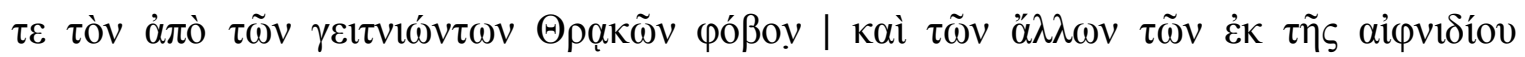

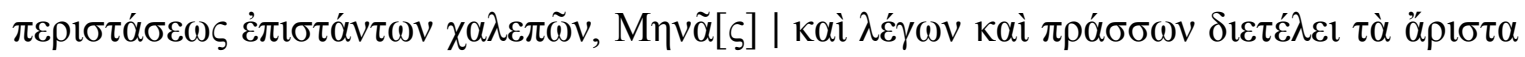

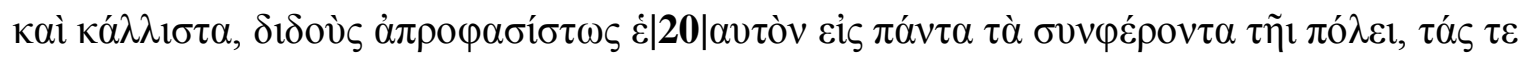

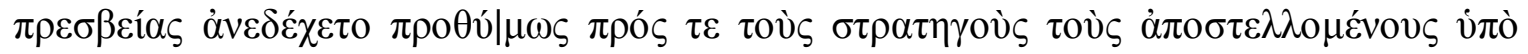

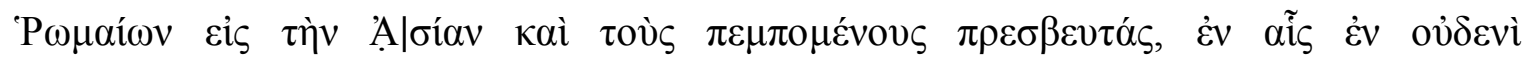

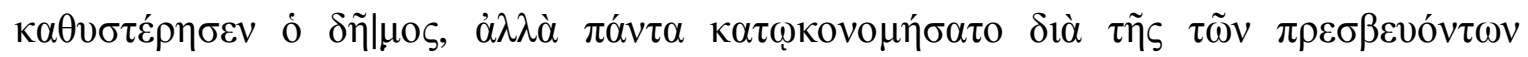

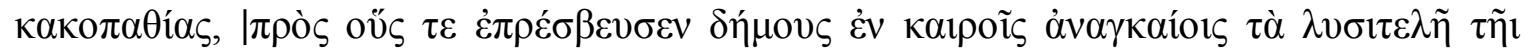
$\pi \alpha \tau \rho i ́ \delta 1 \mu \varepsilon|25| \tau \grave{\alpha} \tau \tilde{\omega} v \sigma 0 v \pi \rho \varepsilon \sigma \beta \varepsilon v \tau \tilde{\omega} v \kappa \alpha \tau \varepsilon \sigma \kappa \varepsilon v ́ \alpha \sigma \varepsilon v$.

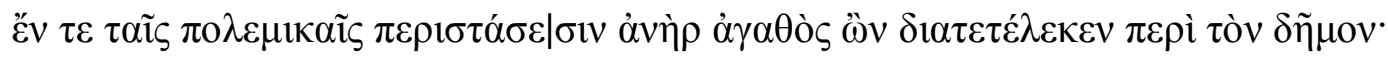

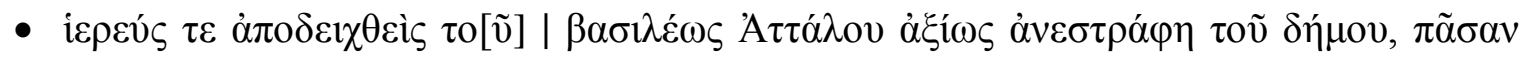

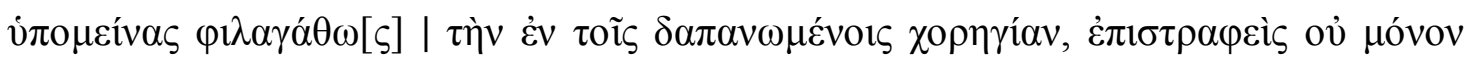

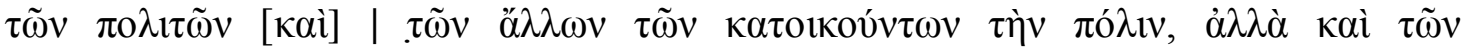

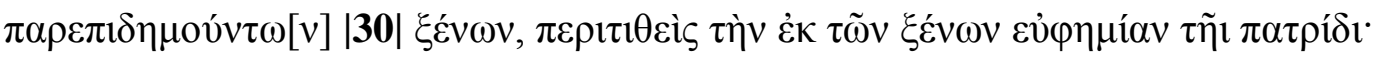

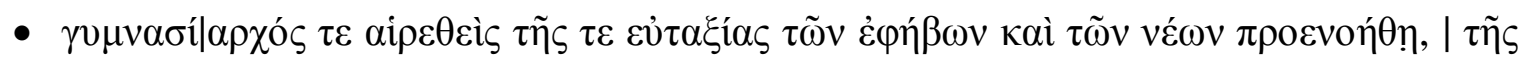

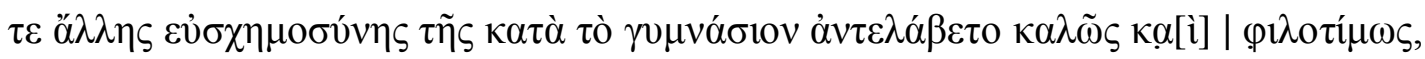

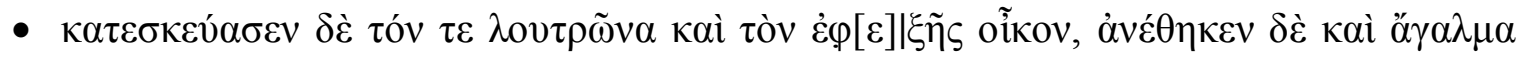

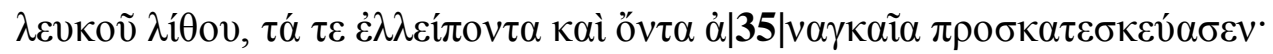

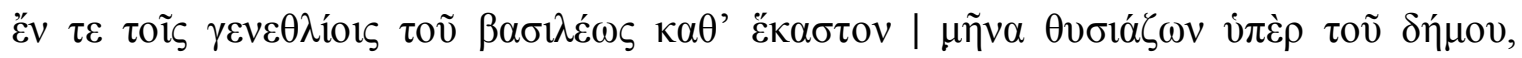

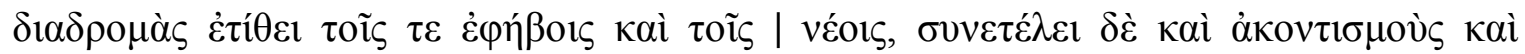

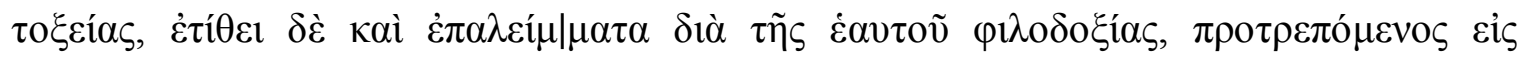

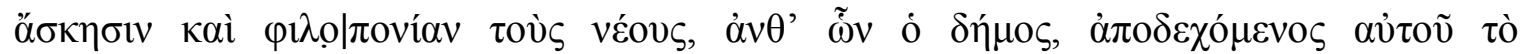

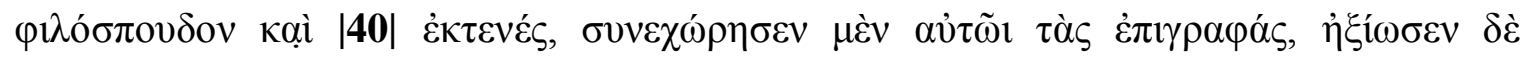

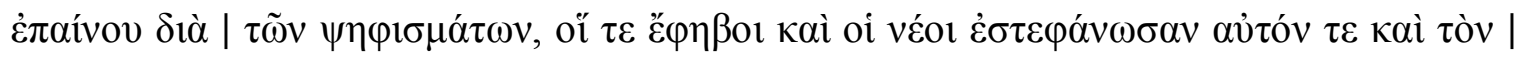

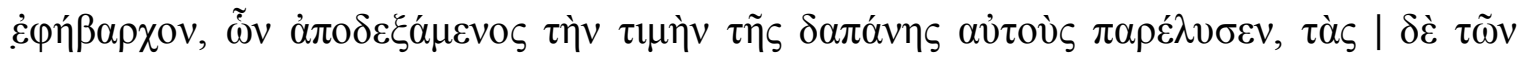

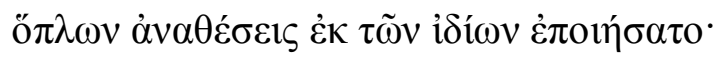


When Glaukios son of Killaios was priest, in the month of Hyp[erberetaios _ _ _ it seemed good to] the boulē and the dèmos, Menandros son of Apollas said that: $\mathrm{S}$ [ince Mēnas, son of Menēs] has been excellent [from the b] eginning of his life, working to make himself of service to the fatherland, neither sparing any expense or chorègia, in any way, nor avoiding labour and risk, nor taking into account the damage done to his private wealth by serving as an ambassador for the polis, but treats all these things as secondary and made being noble and friendly to his homeland his highest goal, and always wishes through his personal zeal to provide something of service to the démos, and to bring about everlasting glory for himself and his descendants through the gratitude received from the populace,

He performed many embassies to the kings, in which he achieved everything profitable for the demos with the help of his fellow-ambassadors, and guarded piously the trust handed to him, and he also dealt with Stratōn the Stratēgos of the Chersonese \& the places in Thrace and was deemed worthy by him of the most amazing hospitality, because of his scrupulousness in matters of trust, and induced Stratōn to be of service to the polis. He also dealt with all the citizens warmly, and after the kings went to the gods and the polis was in a hazardous position, because of fear of the neighbouring Thracians and because of other difficulties which came about from the unforeseen situation, Mēnas continued to say and do the best and greatest things, giving himself without hesitation for every benefit to the polis, and he eagerly undertook embassies to the generals sent out by the Romans to Asia and to the ambassadors they sent, in which the demos fared not at all badly, but was successful in everything, thanks to the labour of the ambassadors, and in desperate times he negotiated advantageous deals for his fatherland with the demoi to which he went, with the help of his fellow-ambassadors.

In these hostile circumstances, he continued to be a good man for the dèmos. When he was appointed priest of King Attalos, he conducted himself in a manner worthy of the dèmos, virtuously undertaking all the chorēgia in his expenses, considering not only the citizens and those dwelling around the polis, but also the resident foreigners, giving his fatherland a good reputation with foreigners. Chosen as gymnasiarchos, he took care of the training of the ephebes and the youths, and took part in the other maintainance of the gymnasion, well and generously. He constructed the bath-house and the attached dwelling, set up a statue of white stone, and provided the shortfall and necessary expenses as well. Each month, on the birthdays of the king, he would perform sacrifices for the demos, he held races for the ephebes and youths, and also organised javelin-throwing and archery, and also gave oil, for his own glory, encouraging the youths to exercise and industry, in return for which the demos, approving of his enthusiasm and generosity, granted him honorific inscriptions and in a decree deemed him worthy of a commendation, and the ephebes and youths crowned him and [made him] ephebarch. And when he accepted the honour of these things, he freed them from the expense, and made the dedication of arms from his private wealth. 


\section{OGIS 339 : Sestos : 133-120 BC (Part Two)}

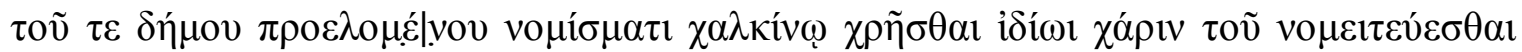

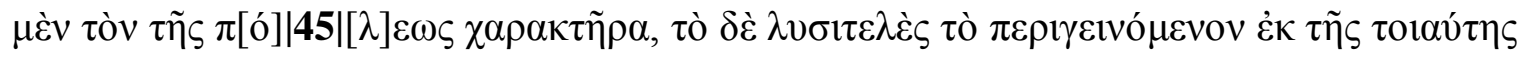

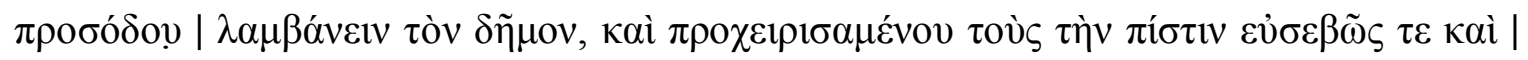

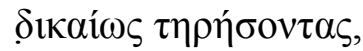

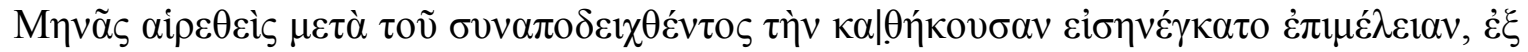

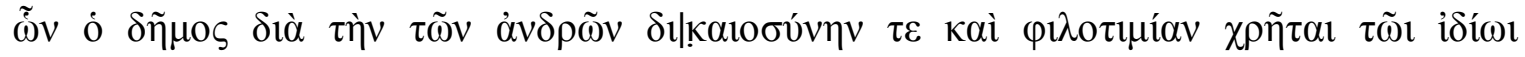

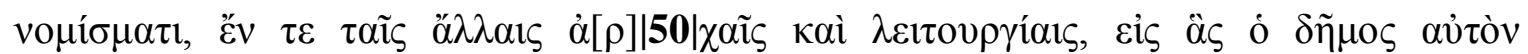

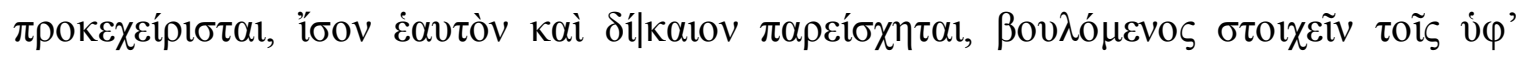

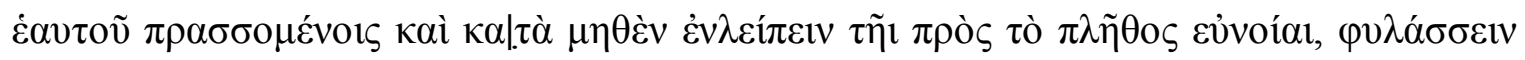

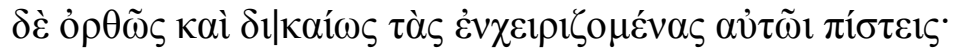

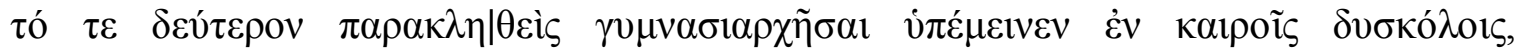

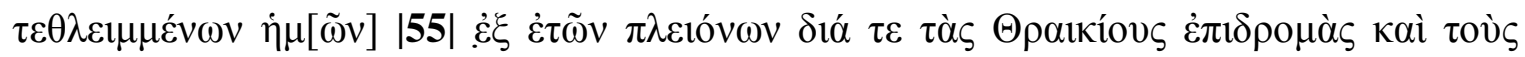

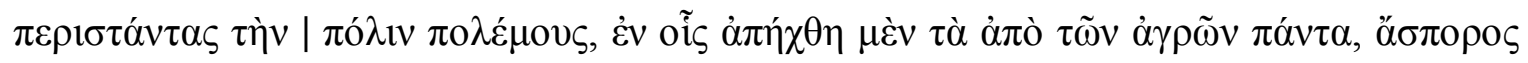

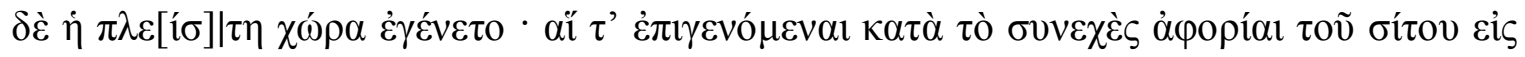

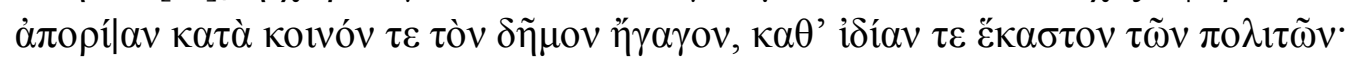

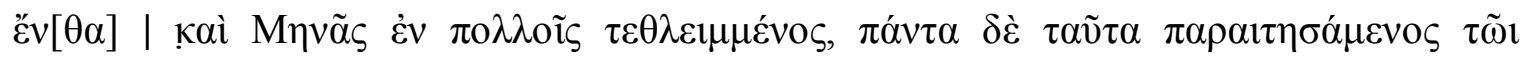

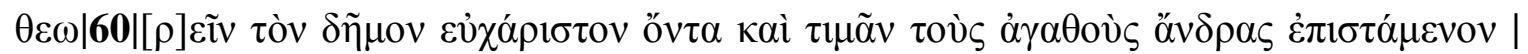

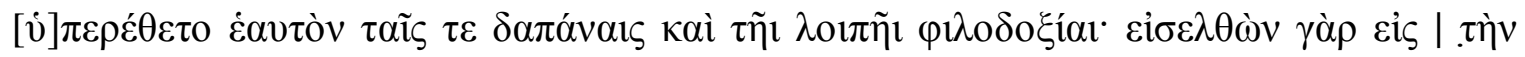

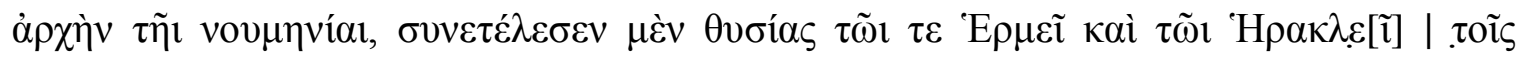

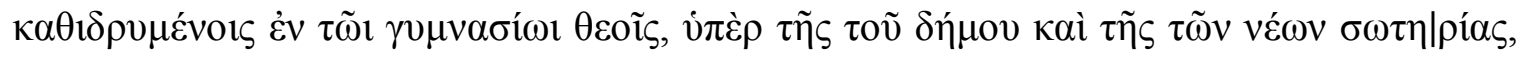

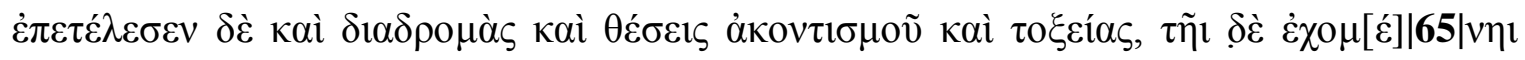

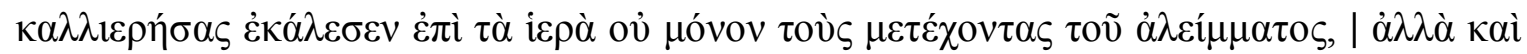

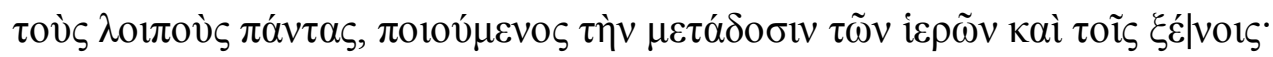

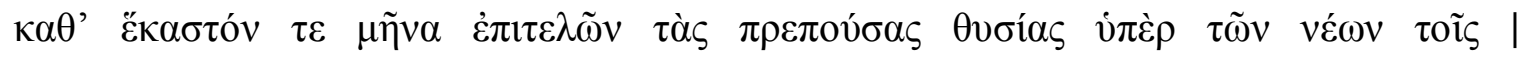

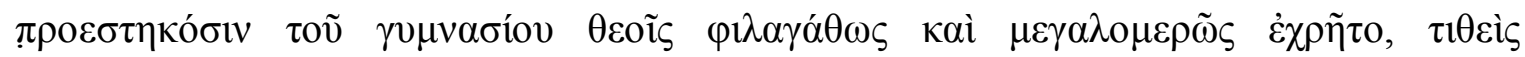

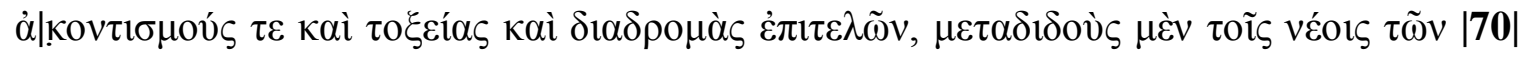

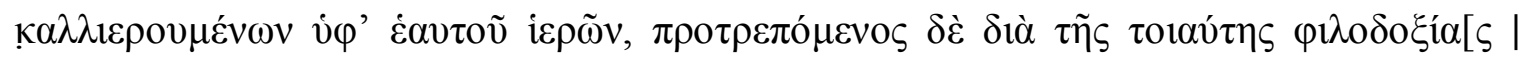

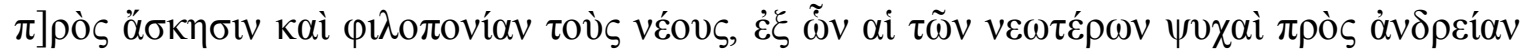

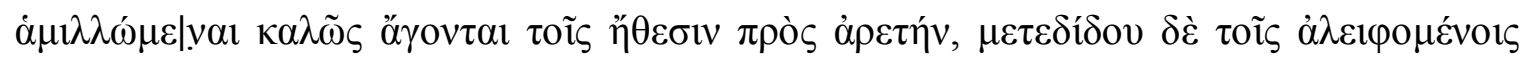

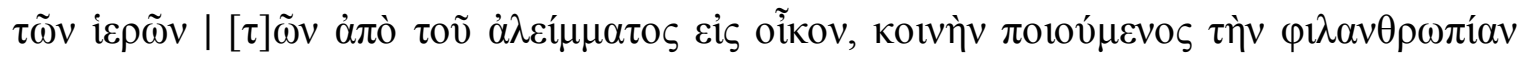

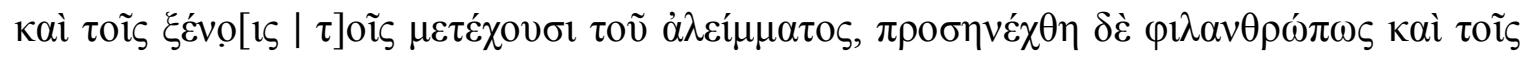

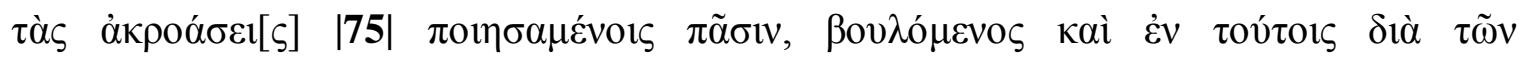

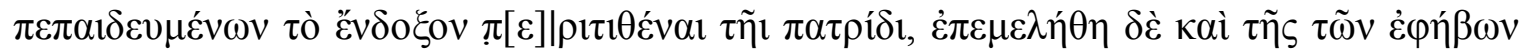

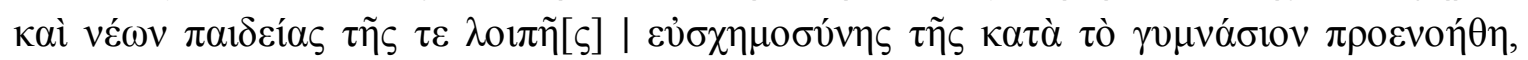

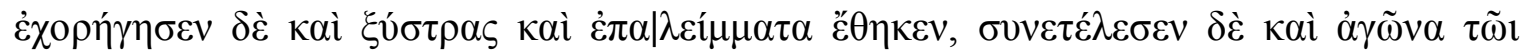

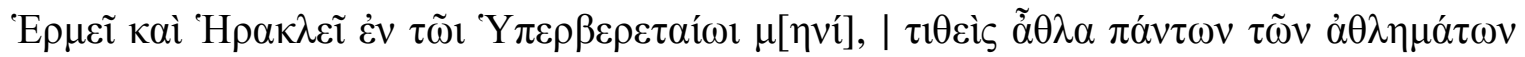

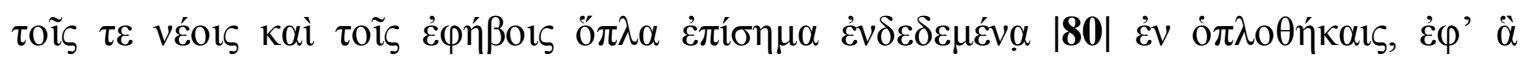

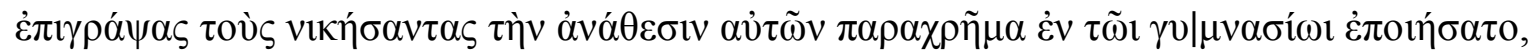

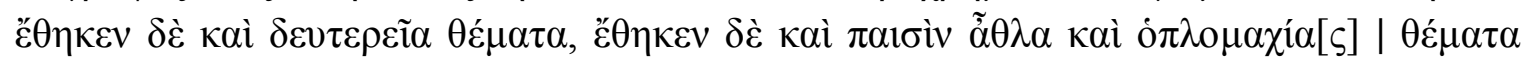

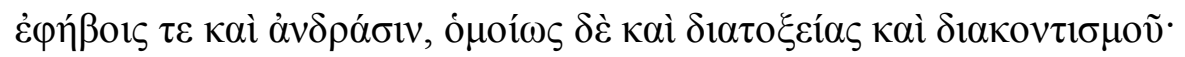


When the dēmos decided to use its own copper currency, in order to make common use of the distinctive coin-type of the polis, and so that the demos take the accompanying profit from this income, and appoint those who would maintain that trust piously and justly,

Mēnas was chosen, and with his co-apointee he contributed proper care and, as a result of the righteousness and ambition of these men, the demos uses its own coinage, and in other magistracies and public services, for which the demos chose him, he offered himself fairly and justly, wishing to match his earlier deeds and in no way to abandon his goodwill towards the multitude, and to correctly and justly guard the trust handed to him.

When he was summoned to be gymnasiarchos a second time he served in troubled times, as we were oppressed for many years by Thracian raids and hostile sieges of the polis, in which everything was carried off from the fields - the majority of countryside went uncultivated. The unceasing dearth of grain led the demos in general and each of the citizens individually into difficulty.

Then, too, Mēnas though oppressed in many ways, was responsible in everything for seeing the démos grateful and able to honour the good men and he exceeded himself by his expenditure and the other aspects of his love for glory. For he entered the magistracy on the new moon, carried out sacrifices for Hermēs and Heraklēs (the gods consecrated in the gymnasion) for the salvation of the demos and of the youth, and he also completed the races, and held [contests of] javelin-throwing and archery, and when he received favourable omens for it to be held, he summoned to the temple not just those sharing in the oil [i.e. the youth], but also everyone else and included a portion of the sacrifices even for the foreigners.

Each month he performed the proper sacrifices for the youth to the gods set over the gymnasion virtuously and sumptuously, held javelin-throwing and archery and held the running race, distributing his good-omened share to the youth and out of such love of glory he urged the youth to exercise and industry, as a result of which the spirits of the younger ones compete in bravery well and are lead to excellence in character, and he distributed the sacrifices of the oil that were for the anointed ones [i.e. the youth] to their households. He made this benefaction a shared one even with the foreigners sharing in the oil, and he behaved generously also to all those giving lectures, wishing in these things too to bestow glory on the fatherland as a result of the youth being educated, and he organised also the education of the ephebes and the youth and the other refinements which are provided in the gymnasion. And he also paid for the strigils and got the perfume and carried out the games for Hermēs and Heraklēs in the month of Hyperberetaios, providing to the youth and the ephebes, as the prizes of all the contests, inscribed shields contained in a shield-case, on which he inscribed the victors and dedicated them in the gymnasion on the spot. He provided the second place prizes also and he provided prizes for the kids and the prizes in the hoplomachia for the ephebes and men, and likewise also for the archery and the javelin-throw. 


\section{OGIS 339 : Sestos : 133-120 BC (Part Three)}

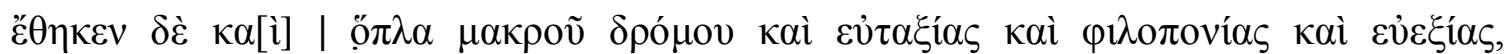

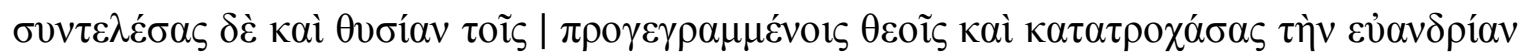

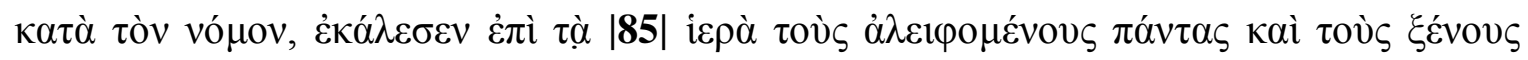

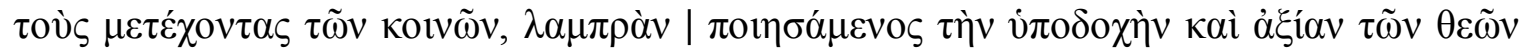

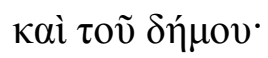

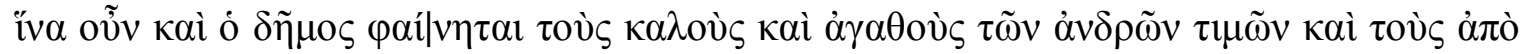

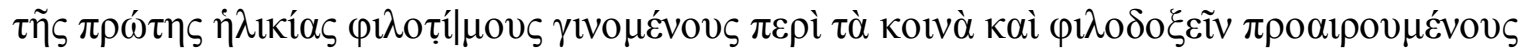

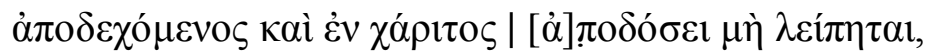

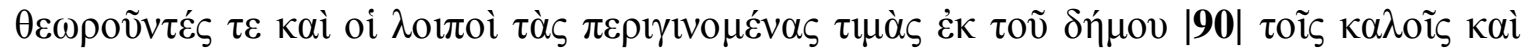

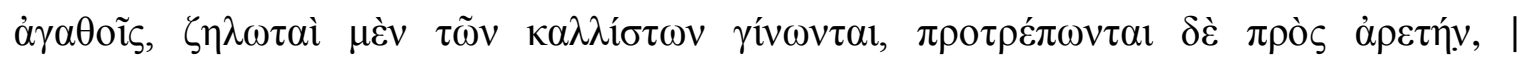

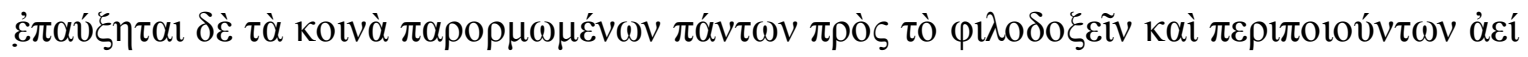
$\tau \imath \tau \tilde{\eta} \imath \mid \pi \alpha \tau \rho i ́ \delta \iota \tau \tilde{\omega} v \kappa \alpha \lambda \tilde{\omega} v$.

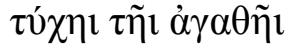

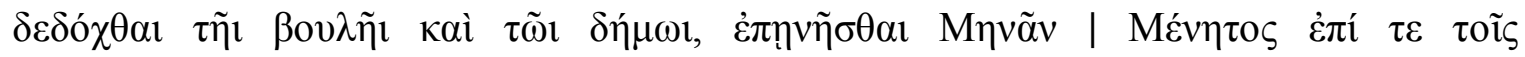

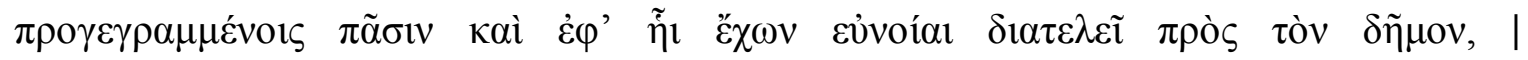

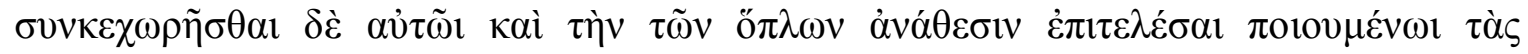

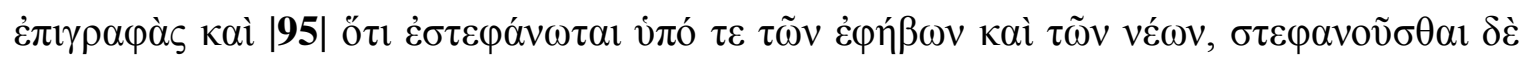

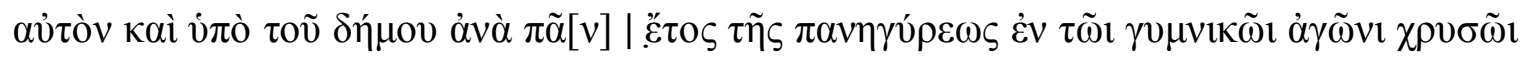

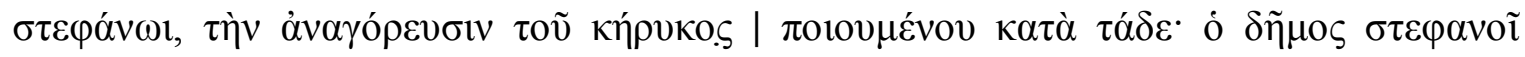

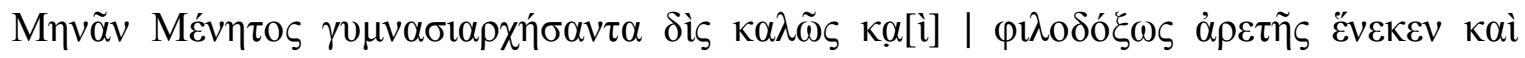

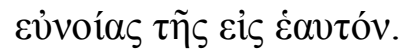

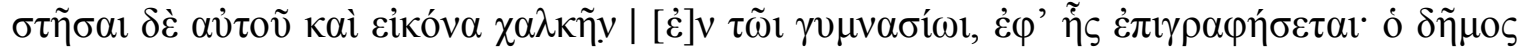

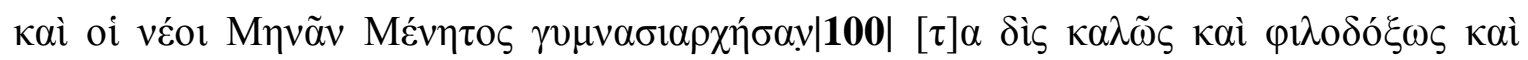

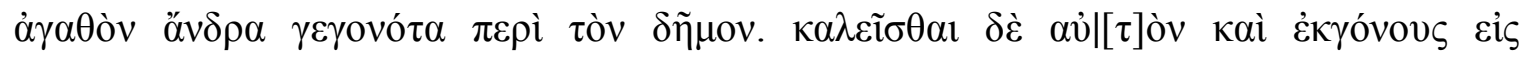

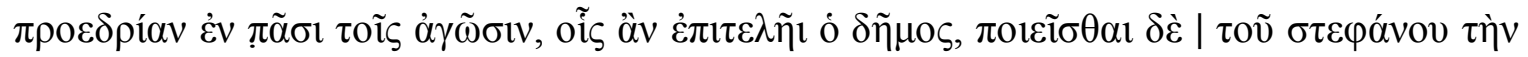

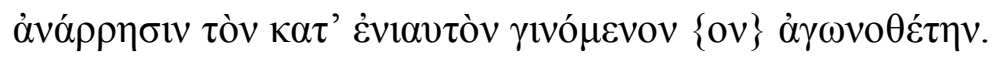

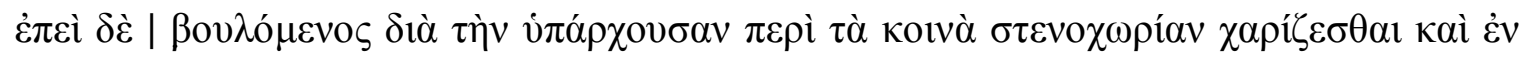

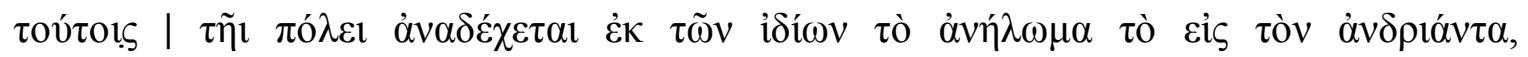

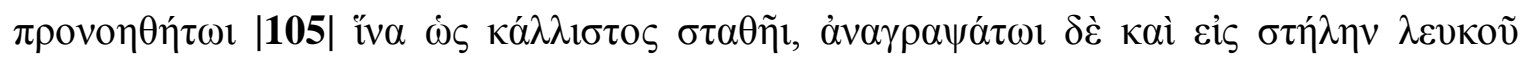

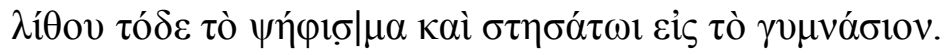


He also made the shields of the long race, and created discipline, industry, and good health, carried out the sacrifice for the aforementioned gods, promoted their physical fitness according to law, and summoned to the sacrifices all the annointed ones, and the foreigners, who shared them in common, and made a brilliant feast, worthy of the gods and the dèmos.

Therefore, so that the demos may be seen to honour the great and good men and those who have been honour-loving with respect to the common things from the beginning of their lives and may be seen to welcome those who choose to love glory and so that [the dèmos] does not fall short in repayment of favours,

And so that others, seeing the honours which come from the demos to the great and the good, might become emulators of his greatness and be urged on to excellence and so that the dèmos might be strengthened, with everyone eager to seek glory in communal service and to be great by always supplying something to the fatherland:

\section{Good Fortune!}

It has been resolved by the boule and the demos,

- That Mēnas son of Menēs has been praiseworthy in all the aforementioned things and in the goodwill which he continues to hold towards the demos,

- That it was allowed by him also to carry out the dedication of the shields and to make the inscriptions, as a result of which he was crowned by the ephebes and the youth,

- That he should be crowned by the demos too, with a gold crown in the gymnasion contests at the festivities throughout the whole year, with the herald making the announcement thus, "The dēmos crowns Mēnas son of Menēs, who twice served well as gymnasiarchos with love of glory, on account of his excellence and his goodwill towards it,"

- And also to set up a bronze statue of him in the gymnasion, on which will be written, "The dèmos and the youth [honour] Mēnas son of Menēs, who twice served well as gymnasiarchos with love of glory, who has been a good man for the dèmos."

- And to summon him and his descendents to the front-seats at all the contests the dèmos will hold, and the man in charge of the games that year is to arrange the announcement of his crown.

Since the demos wishes to show the gratitude it holds during the difficulties which surround the community and in these things he provided the cost of the statue for the polis from his private wealth, let care be taken that he be confirmed to be brilliant and let this decree be copied onto a stele of white stone and let it be set up in the gymnasion. 


\section{SEG 35.925: Chios : c.330 BC}

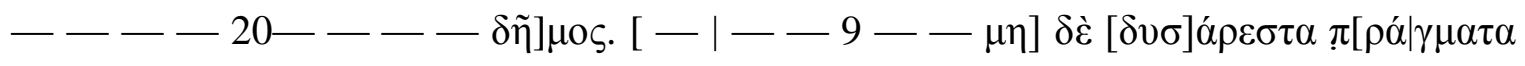

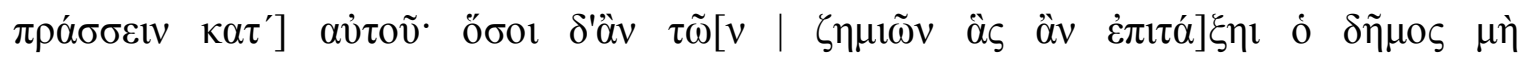

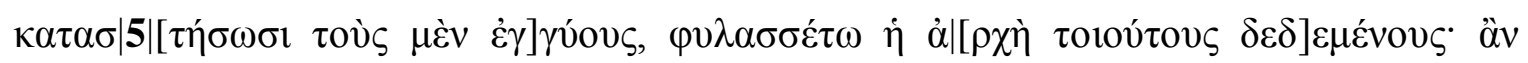

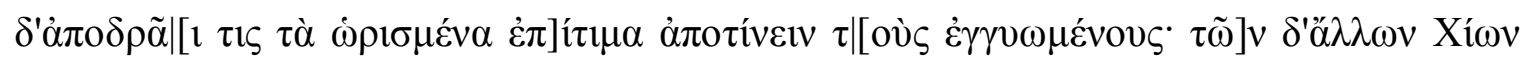

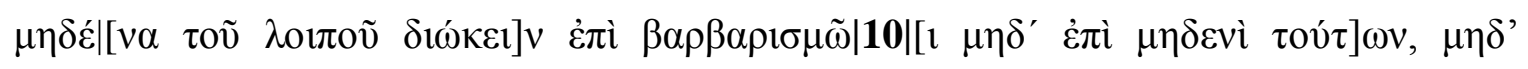

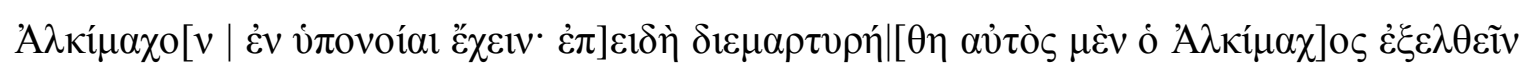

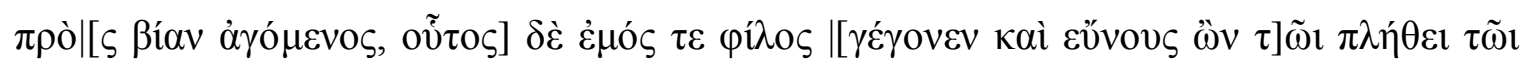

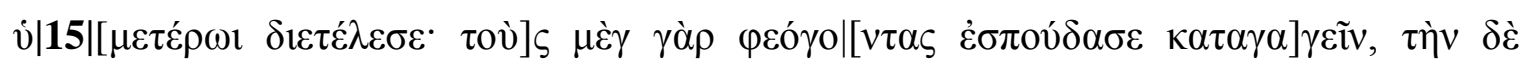

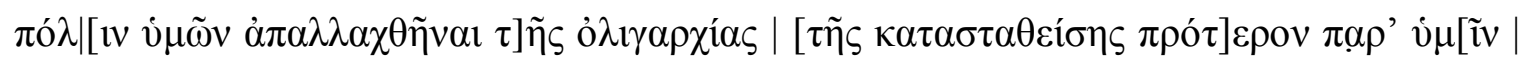

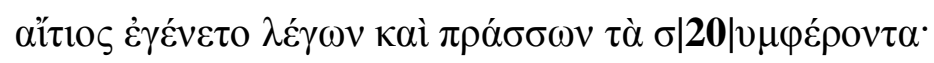

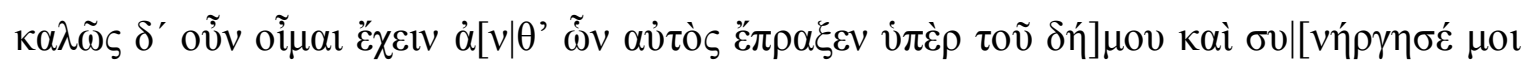

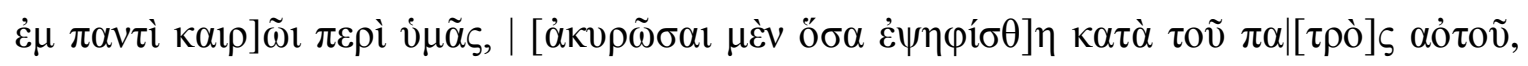

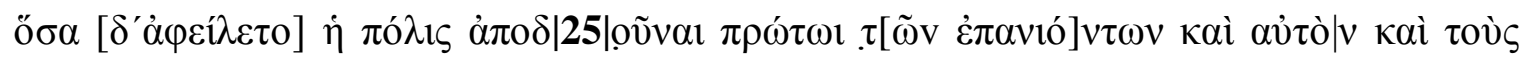

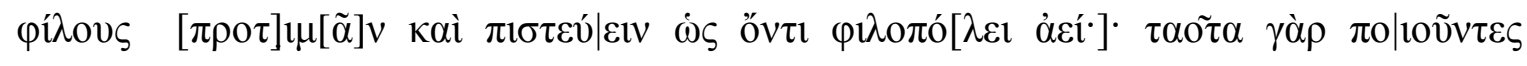

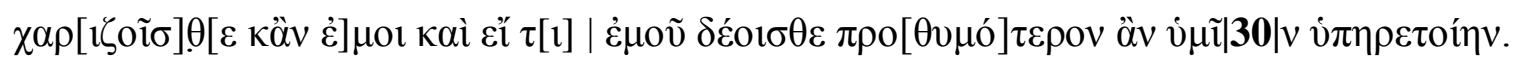

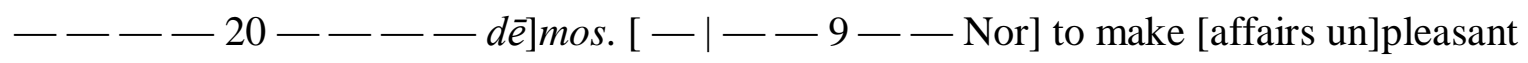
to him, and whoever does not [arrange gua]rentees of the [fine, which] the dēmos shall [comm]and, let the board imprison them, and should [one] of them escap[e, the guarantors] must pay [the decreed am]ount. No one of the other Chians are to [prosecute the remainder] for barbarising [or prosecute them for anything], or [hold] Alkimachos [in suspiscion], since [Alkimachos himself] was testified to been forced to act excessively in [response to force] and he is my friend and [remains friendly to your] populace. Furthermore, [he was eager for] the exiles to [return], and by saying and doing beneficial things he was responsible [for your] polis [being set free from] the oligarchy, [which was formerly established over you].

Therefore, I [i.e. Alexander the Great] think it is appropriate, in [exchange for the things he did for the $d \bar{e}$ ]mos and for ass[isting me in every matter] of yours, [to cancel the things decr]eed against his fa[the]r and to give back those things which the polis [took] at first from [those who are returning], [to h]on[our] him and his friends and to trust him as always being a friend of his polis. By doing these things, you [would] gratify me and if you should need something from me I would serve you more eagerly. 
SEG 36.1280 : Seleukeia-in-Pieria : 197 BC

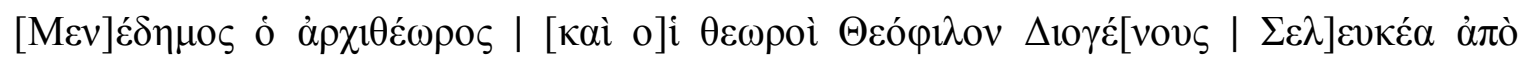

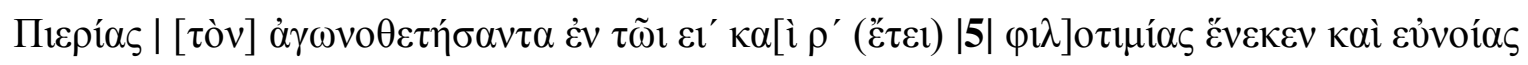

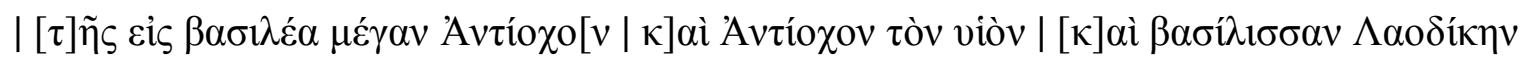

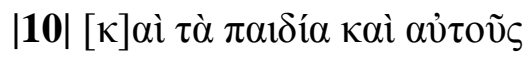

Architheōros Menedēmos and the theōroi [honour] Theophilos son of Diogenēs, the Seleukeian from Pieria president of the games in [1]15 [197 BC], on account of his love of honour and his goodwill towards Great King Antiochos [III], Antiochos the Son, Queen Laodikē, the children, and themselves. 


\section{Syll 344 : Teos : 303 BC (Part One)}

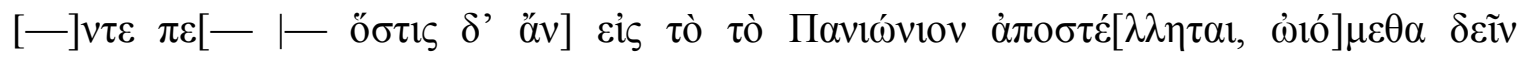

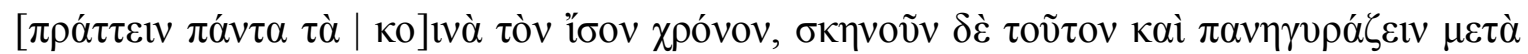

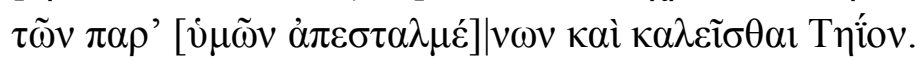

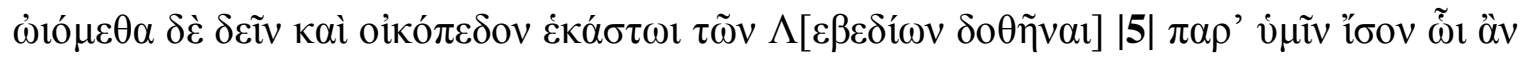

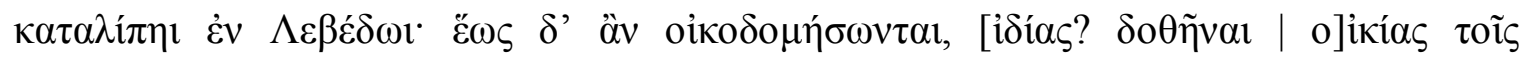

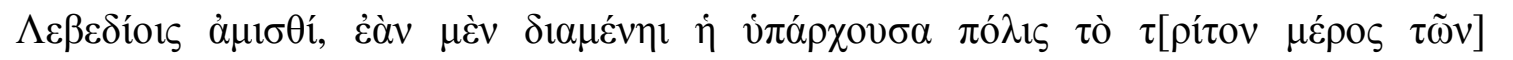

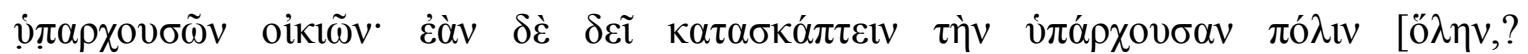

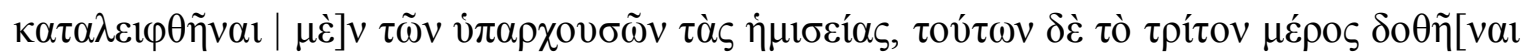

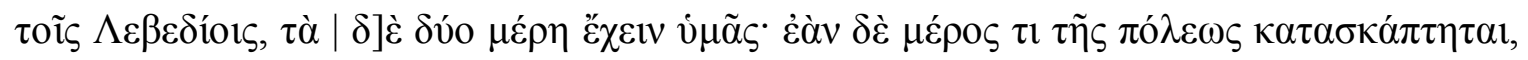

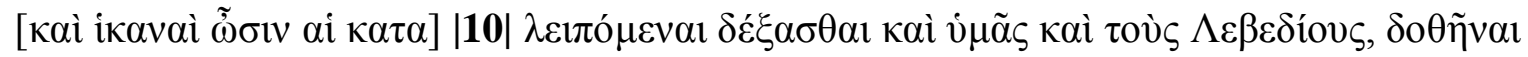

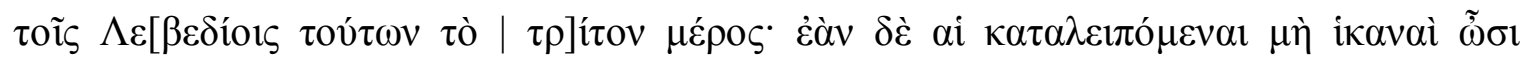

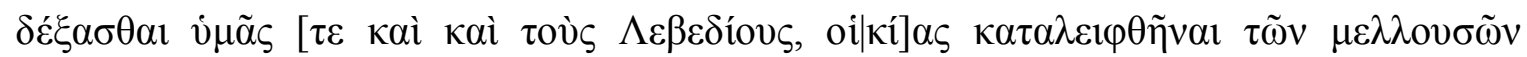

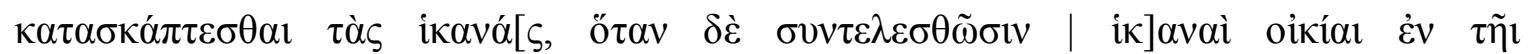

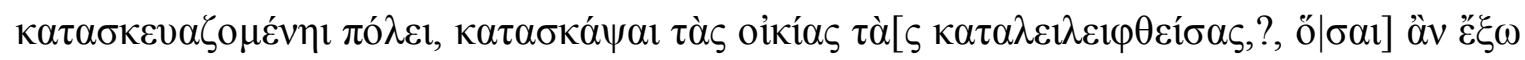

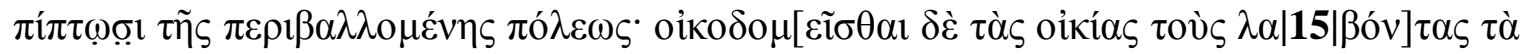

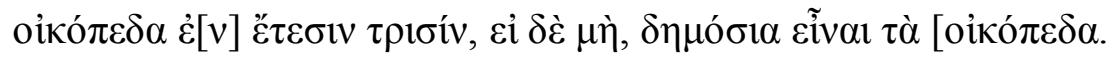

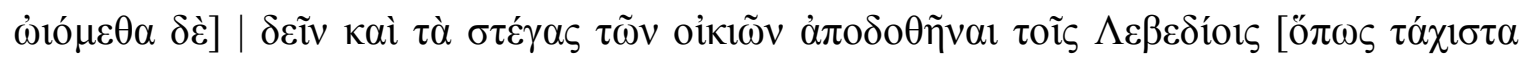

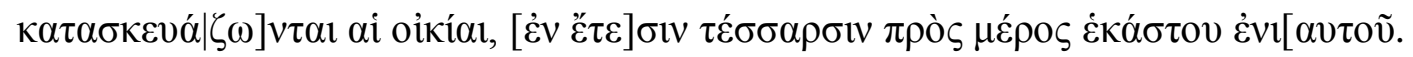

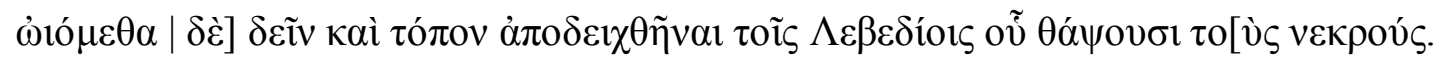

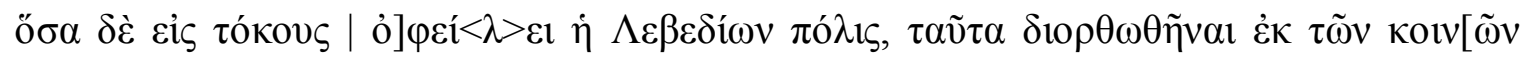

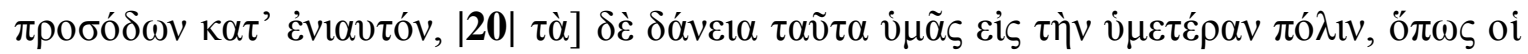

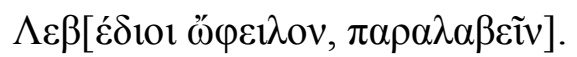

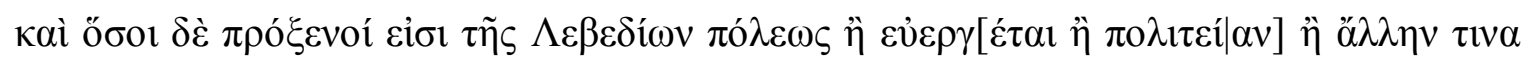

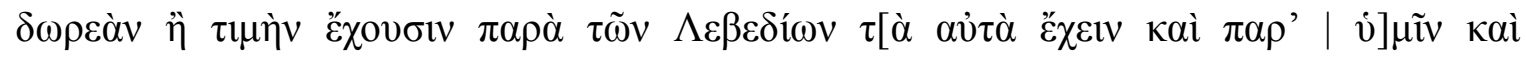

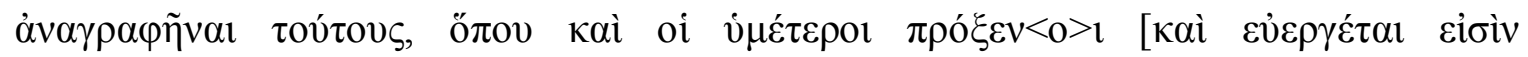

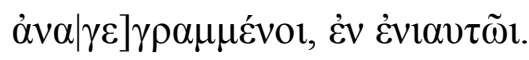

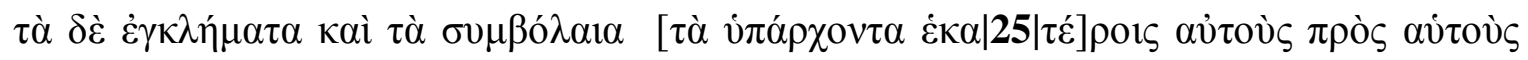

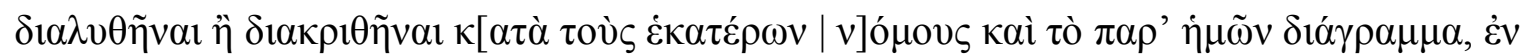

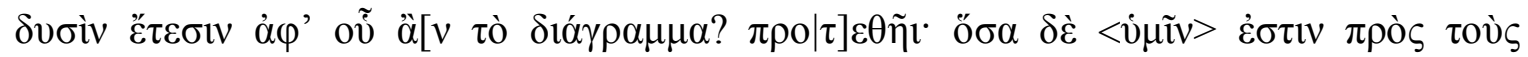

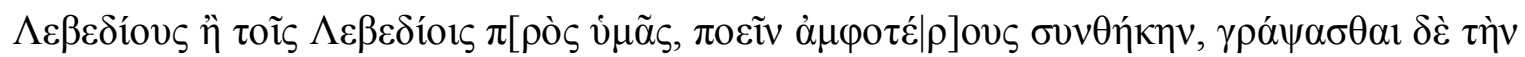

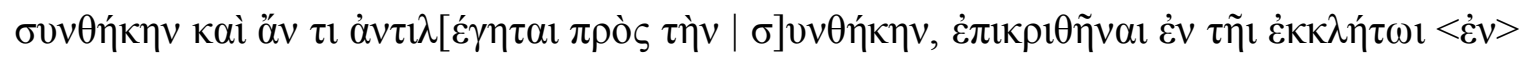

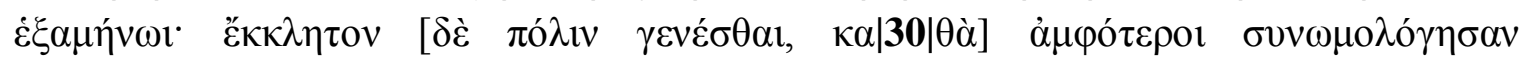

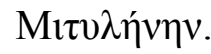


[ _ _ _ - whoever of the Lebedians? is] sent to the Paniōnion, we think it necessary that they [do all the common things] for equal time, encamp there and celebrate with those [sent by you] and be called Tēan.

And we thought it necessary that a household plot [be given] to each of the L[ebedians] by you, equal to what they left in Lebedos. And that [private? houses be given] to the Lebedians rent-free, until they have built themselves houses, if the existing polis retains the t[hird part of the] existing houses, but if it is necessary to raze the [whole?] existing polis, that half of the existing people [be left in place], the third part be given [to the Lebedians], and you hold the other two parts, but if some part of the polis is razed [and the remaining bits are sufficient] to be received by you and the Lebedians, the third part [of those] should be given [to the Lebedians], but if the remnants should not be sufficient for you [and also the Lebedians too] to receive, enough of the houses about to be razed are to be retained, [and when] enough houses [have been finished] in the new polis, destroy the [leftover?] houses, if they are outside the walls built around the polis, and those [taking] plots are to build [their houses] within three years, and if not, the [plots] are to belong to the demos.

[And we thought] it necessary that the roofs of the houses be given to the Lebedians, [so that] the houses [might be built quickly], within four years before the e[nd] of each.

[And we thought] it necessary that the place for the burial of the [deceased] be paid for by the Lebedians.

And however much the Lebedian polis owes in interest, will be rendered from the common [incomes each year,] and you [are to take] these loans into your polis, as the Leb[edians owe them].

And those who are guest-friends of the polis of the Lebedians or who, as benefactors, hold [citizenship] or some other gift or honour from the Lebedians [are to have the same from y]ou and you are to record them where your guest-friends [and benefactors are recorded, within a year.

And [the existing] charges and contracts [in each polis] are to be discharged for each and every one or to be judged [according to the laws of each polis] and our ordinance, within two years from when [this ordinance is rendered]. The cases <of yours> against the Lebedians or of the Lebedians aga[inst you, both poleis are to make an agreement, and the agreement is to be written out and should anything [be disputed in the a]greement, it is to be decided in the Assembly, within six months. And the arbitrating [polis is to be, as] both agreed, Mitylēnē. 


\section{Syll 344 : Teos : 303 BC (Part Two)}

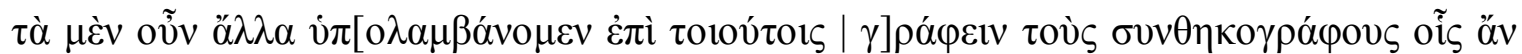

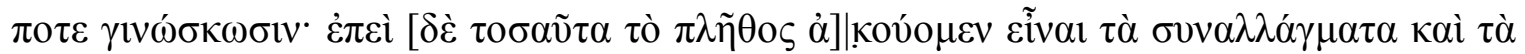

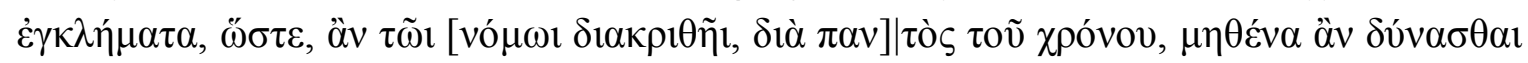

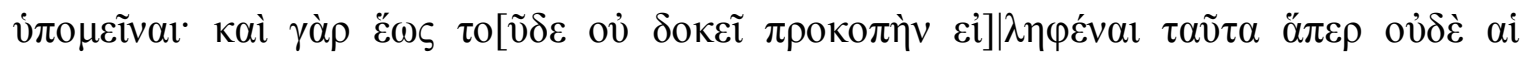

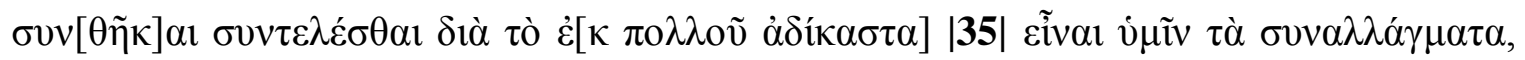

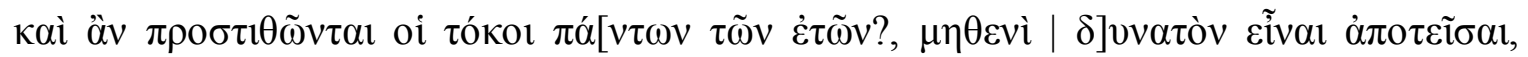

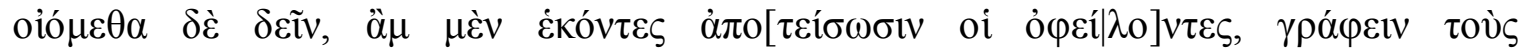

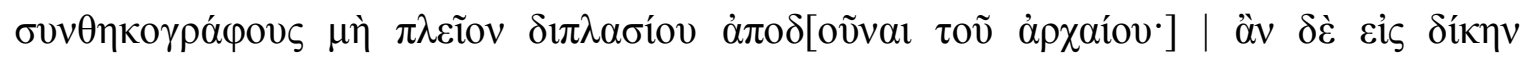

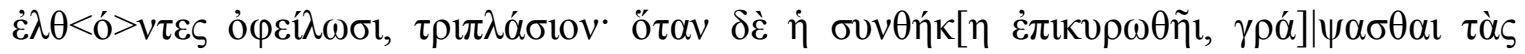

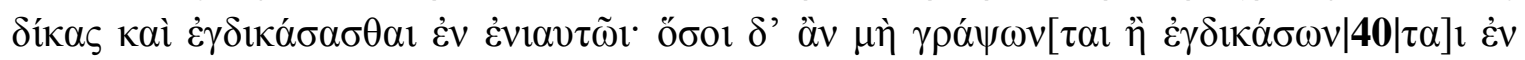

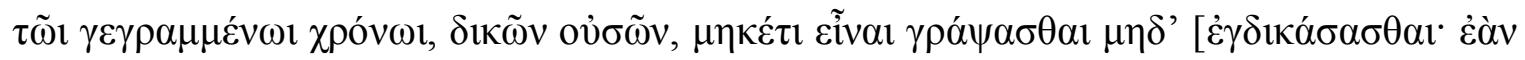

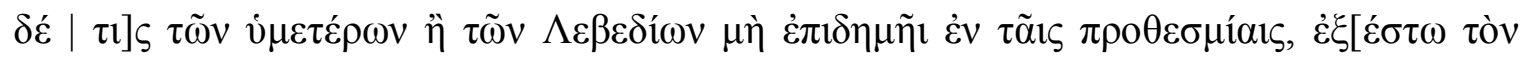

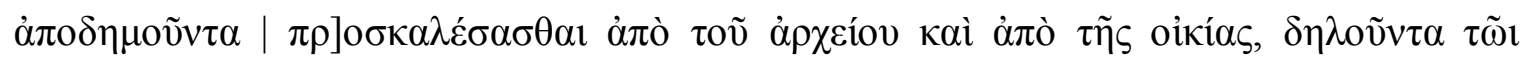

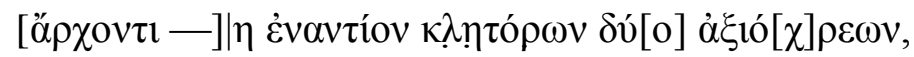

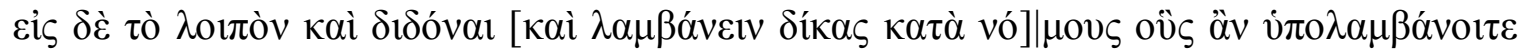

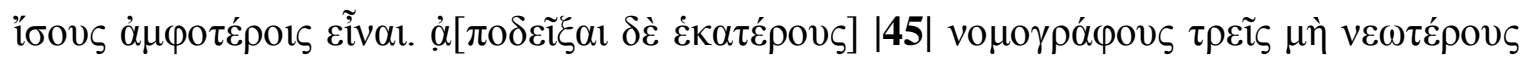

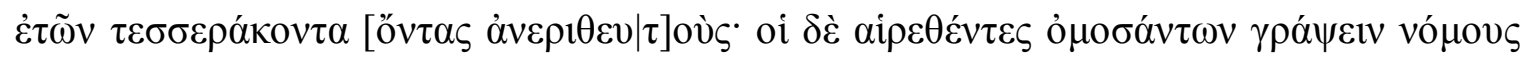

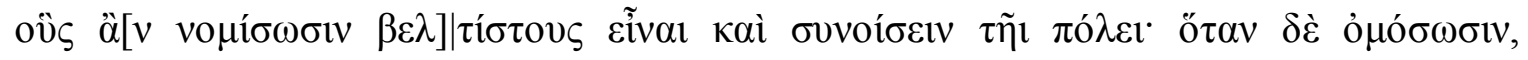

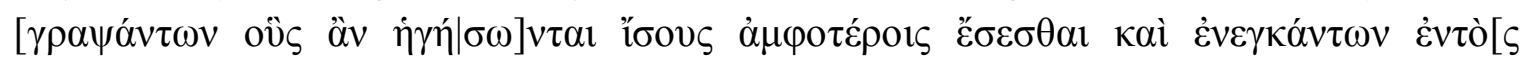

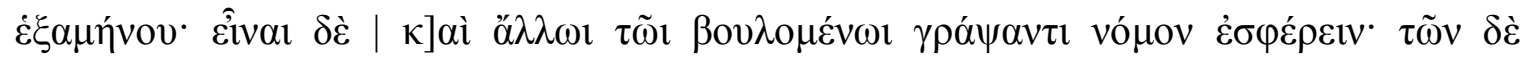

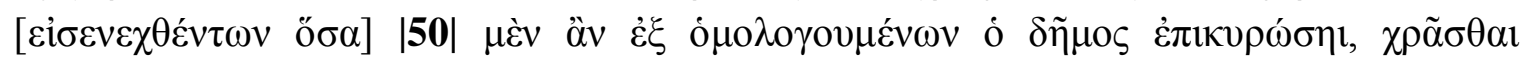

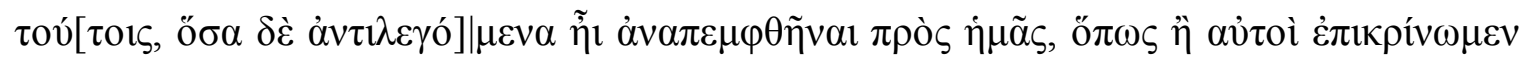

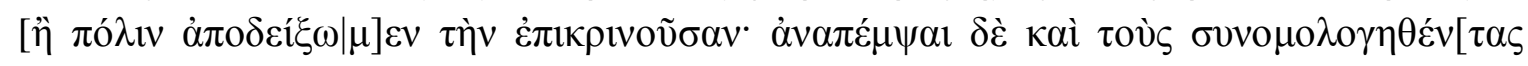

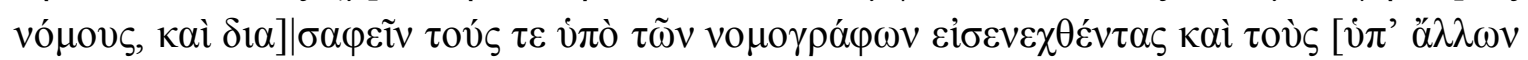

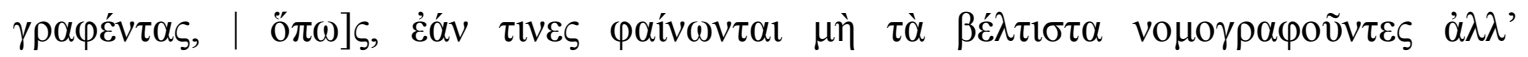

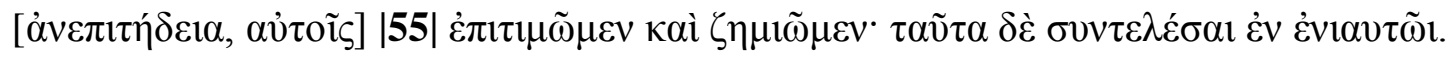

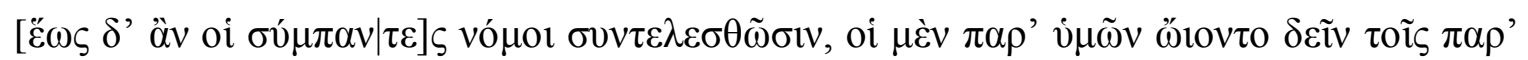

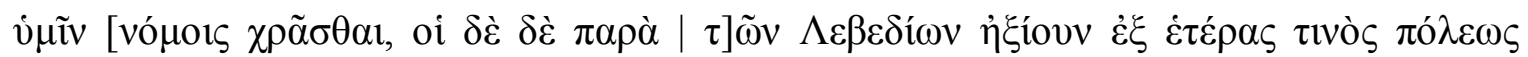

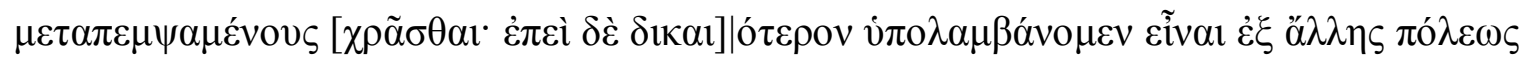

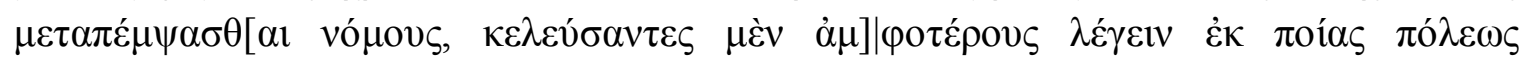

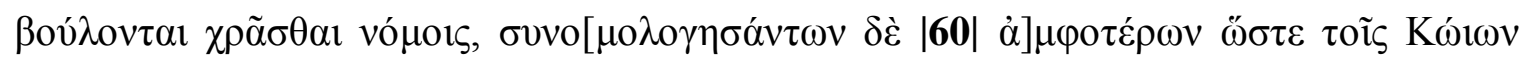

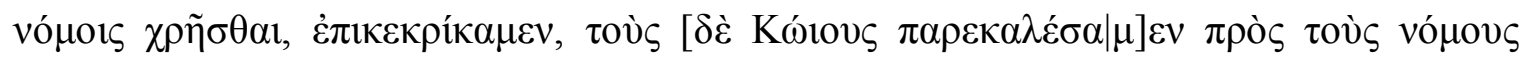

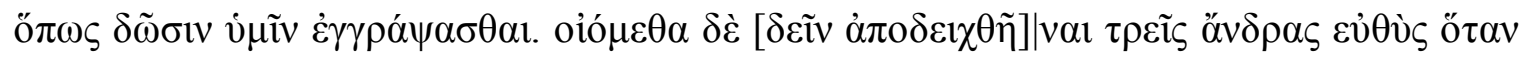

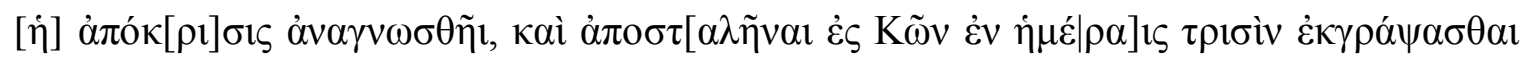

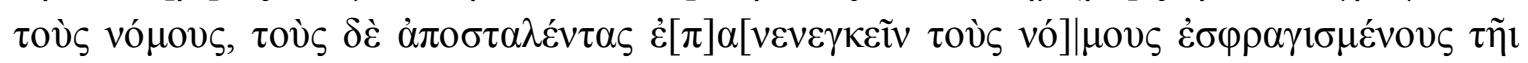

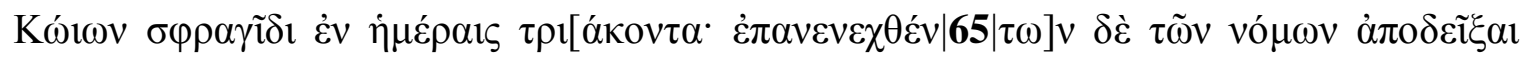

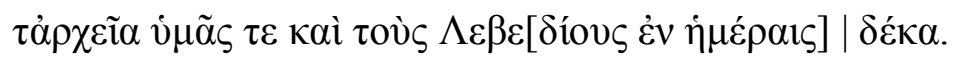


We t[hink] that the notaries should rule on other things additional to these however they should decide them. However, since we hear that the contracts and charges are [so great a multitude], that [should they be judged by law], it would not be possible to deal with them all, [in the wh]ole time [available], for up to n[ow] these agreements of yours, which have not been executed on account of not [being judged in so long] and which, if the interest [of all the years?] were added to them, no one would be able to pay, [do not seem] to have made [progress]. And we think it necessary that the notaries rule that those who willingly pay should pay no more than double [the principal], but should they go to court in debt, three times as much. When the agreement [is confirmed], they may indict and challenge their contracts within a year. Should they not indict or [challenge] the existing contracts within the aforementioned time, they will be binding and no longer to be indicted or [challenged. And if someon]e of you or the Lebedians should not be in town within the appointed time, [allow the absent one] to be charged at the town hall or their house, and notify the [archon], before two worthy arbitrators.

In future people are to give and [receive justice according to] whichever [1]aws you undertake to apply fairly for both [and each polis is to assign] three [uncorrup]ted lawwriters, no younger than forty years of age. Those chosen should swear to write laws which [they think to be be]st and beneficial to the polis. When they have sworn, they [should write laws which believe] will be fair to both and they should do this within [six months. I]t is permissable for any other willing writer to contribute a law. When the draft laws [are returned], the demos should use those of the laws which it confirms by common consent, but those which are contested should be sent away to us, so that we may arbitrate [or select a polis] to arbitrate. Send the agree[d laws] also, and make clear which were produced by the law-writers and which by other writers, so that if some of the law-writers seem have drafted things which are unfair instead of being the best, we can penalise and fine them. These things are to be done within a year.

[Until all the] laws are done, your envoys thought it necessary [to use] your [laws, but the] Lebedian [envoys] preferred to [use] laws transferred from some other polis. [Since] we think that it is more [just] that [laws] be transferred from another polis, [we called upon] both parties to discuss which polis they want to use the laws of. When both agreed to use the laws of the Kōans, we agreed and [we contacted] the Kōans about their laws, so that they might give a transcription to you. And we thought [it necessary] for three men to be [chosen] immediately, when the answer was known and to send them [to Kōs within] three [days] to transcribe the laws. Once dispatched, they were to [bring] back [the] laws sealed by the Kōan seal within th[irty days]. When the laws are returned, you and the Lebe[dians] are to fill the magistracies [within] ten [days]. 


\section{Syll 344 : Teos : 303 BC (Part Three)}

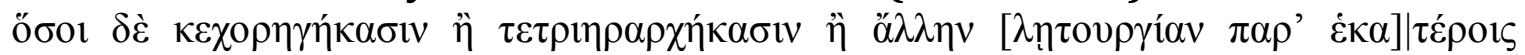

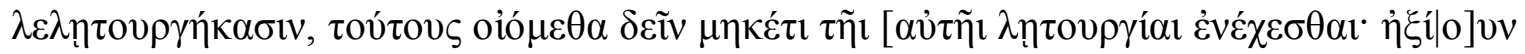

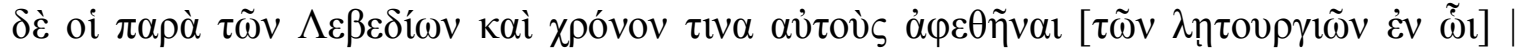

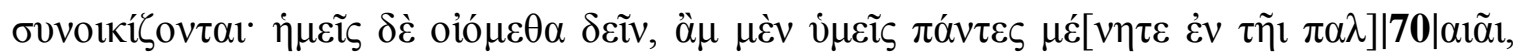

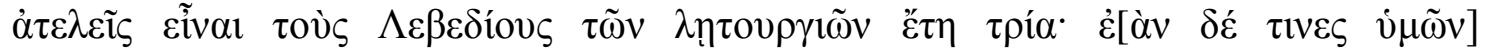

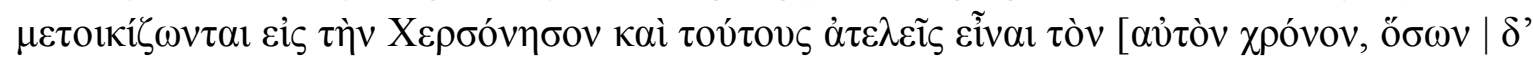

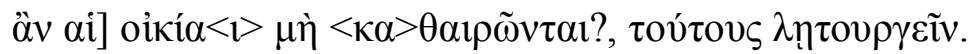

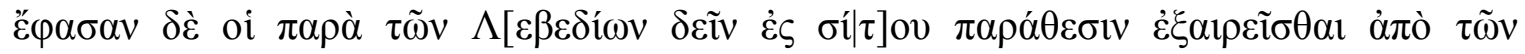

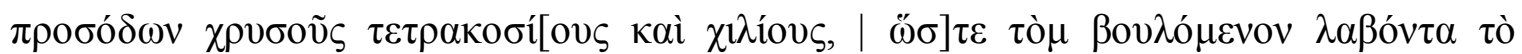

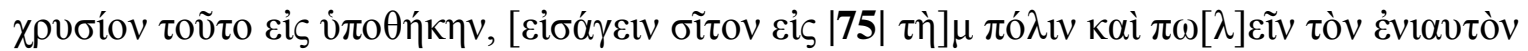
ó

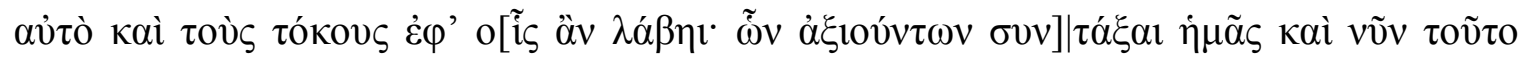

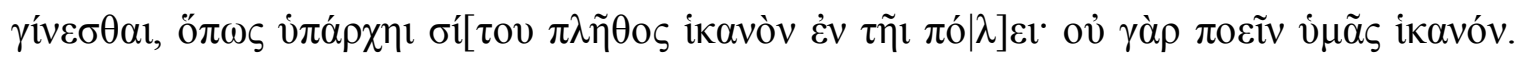

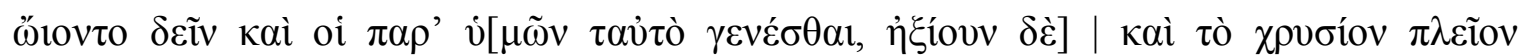

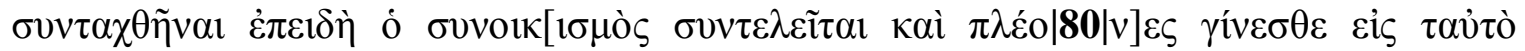

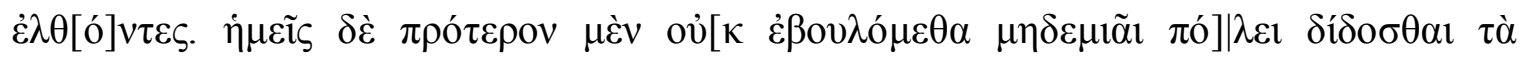

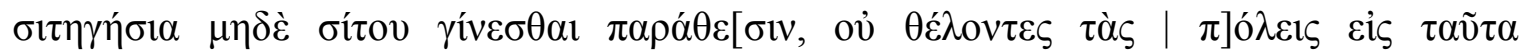

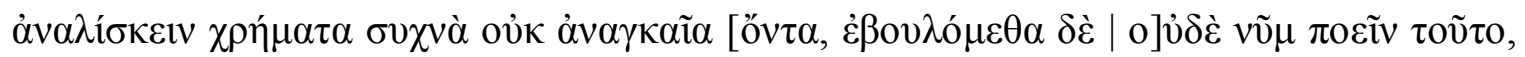

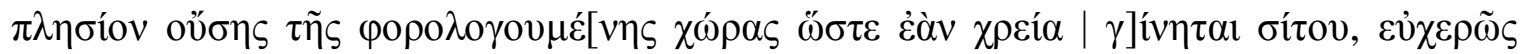

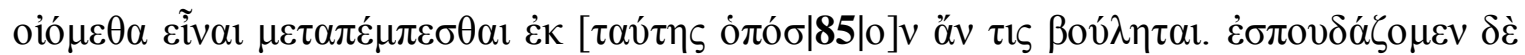

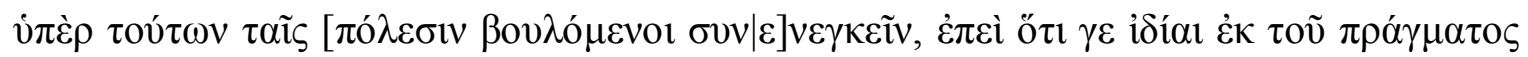

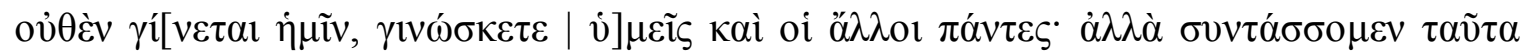

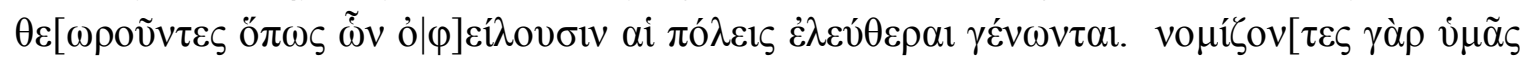

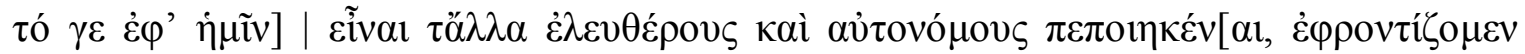

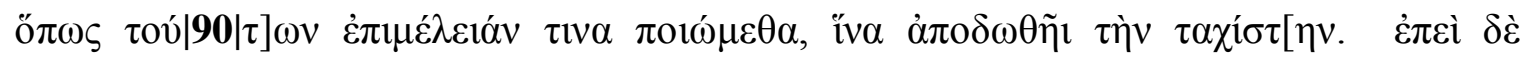

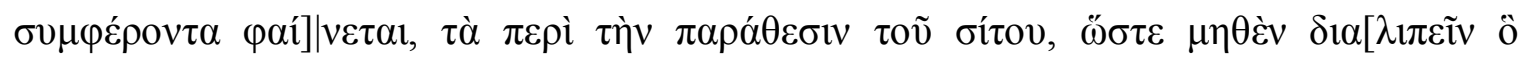

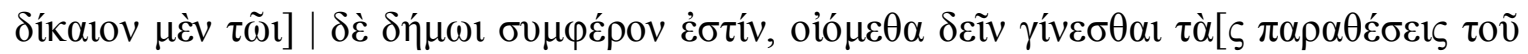

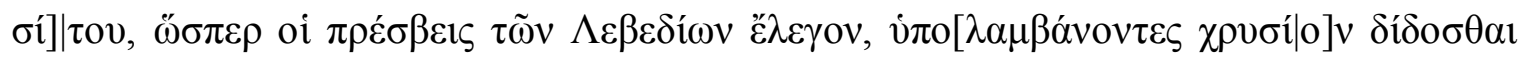

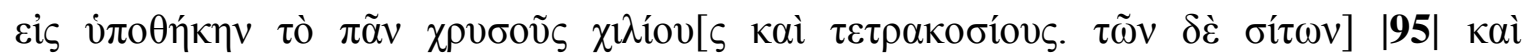

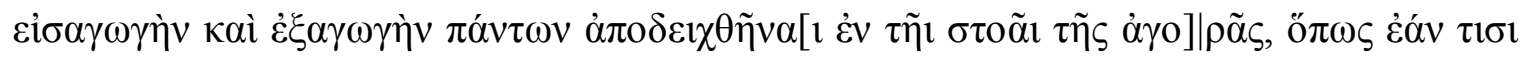

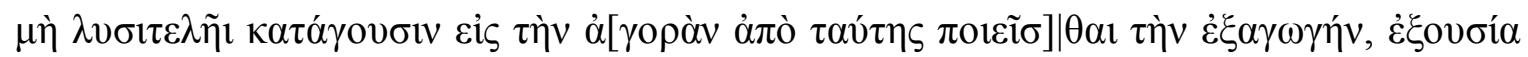

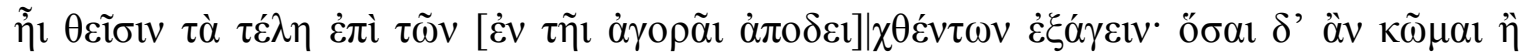

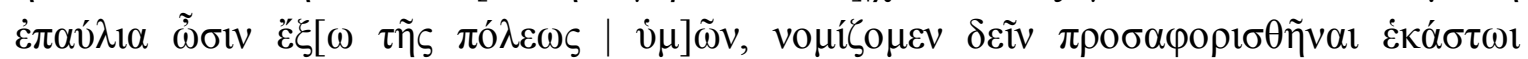

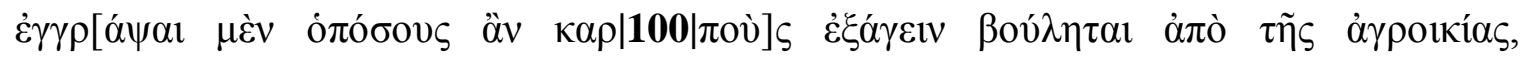

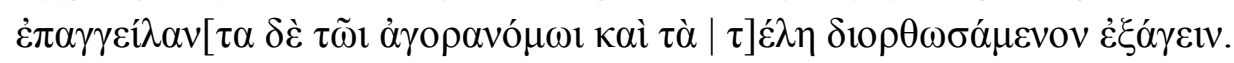

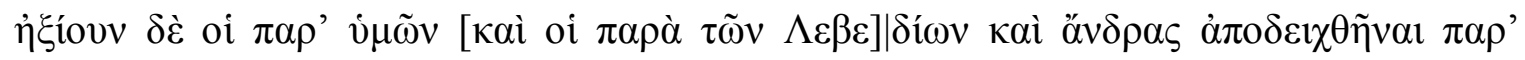

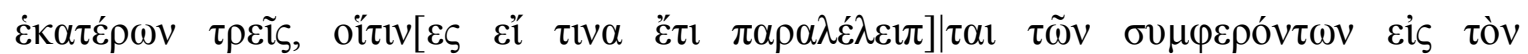

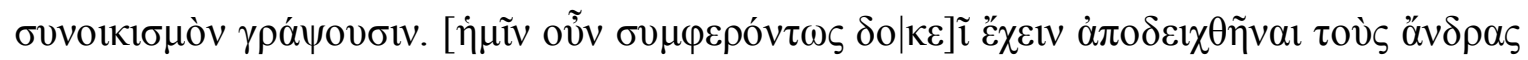

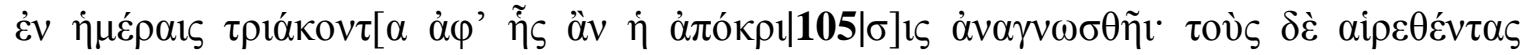

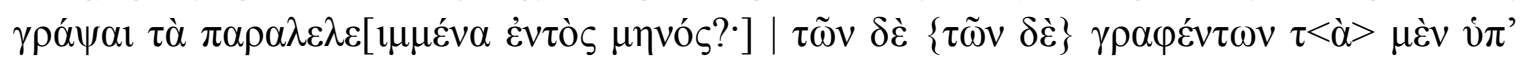

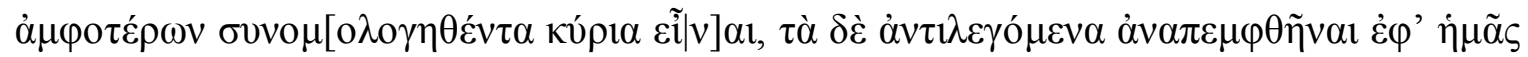

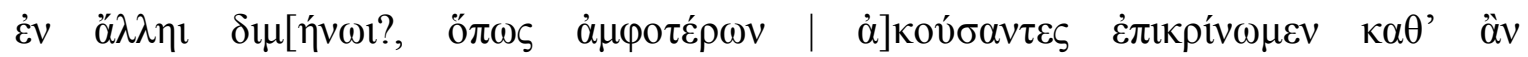

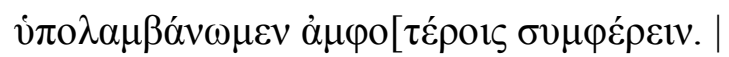


Those who have been chorēgos or triērarchos or have performed another [liturgy for either polis, we think it necessary that they not [be subject to that same liturgy]. But the Lebedian envoys thought also that for some time they ought to be released from [liturgies in the] synoikism. And we think that it is necessary, should you all rem[ain in the] old polis, that the Lebedians be exempt from liturgies for three years. But i[f some of you] transfer to the peninsula, these too are to be exempt for the same period, but [those whose] houses are not <tran>sfered are to perform liturgies.

The L[ebedian] envoys said that [it was necessary] to transfer [one thousand] four hund[red] gold [statērs] from the incomes [into the] grain reserve fund, [so that] someone willing could take this gold as a deposit and [bring grain into the] polis and sell it within the year, whenever he should wish, and when [the year ends, he would return the same amount of gold to the polis and interest w[hich he took] from it. [They thought it best] that we arrange this and do it now, so that [sufficient plenty of gr]ain be available [in the pol]is, because you do not produce enough. [Your] envoys thought it necessary [to do the same, but preferred] that more gold be arranged, since when the synoik[ism is completed, more] people will have come in and settled in the same place. Earlier, we [wished] that the wheat-importing-right not be given to any polis nor that there be a grain reserve fund, [because we did not want the po]leis to spend much money on this when it was not necessary. [We did not wish] to do this now, either, since the tribute-paying [land] is near, [such that should a need] for grain occur; we thought [however much] grain is desired could easily be brought in by [this method]. We were anxious about these things, [wishing to benefit the poleis], that you and everyone else [ensure] that nothing [be taken] from your public affairs for private interests. But, obs[erving] these things, we arranged that the poleis be free from being in debt. [For] we think that we have made [you] free and autonomos in everything and we [were anxious that] we take care of these things, so that it be paid off in the quickest way possible. [But since] the grain fund seemed [profitable], and so that nothing which is just or profitable to the demos cease, we think it best to make the [grain fund] as the Lebedian envoys said, under[taking] that the whole one thousand[d four hundred] gold statērs be given as a deposit. The import \& export of [grain] should all be declared [in the stoa of the ago] ra, so that if bringing it into the $a$ [gora and from there] to export does not profit individuals, the right to export would exist for those paying the dues on the things [decl]ared [in the agora]. We think it necessary in whatever villages and hamlets there should be ou[tside your polis] for each person be ordered to rec[ord how much produce] he wishes to export from the countryside and to record the amount announced to the agoranomos and make the export after paying the duty.

Your envoys [and the Lebedian envoys] also thought that three men from each polis ought to be appointed, to make a ruling [if something] of profit to the synoikism [remains neglected. Thus it seemed profitable to us] to have the men appointed within thirty days [from the] reading [of this decision] and those chosen are to rule on the remain[ing things within a month?] Of the things \{of the things \} written, the thing[s consented in common] by both are to be [binding] and the contested things are to be sent to us within two [months?, so that hearing from both] we may judge what we think [profitable] to both. 


\section{Syll 344 : Teos : 303 BC (Part Four)}

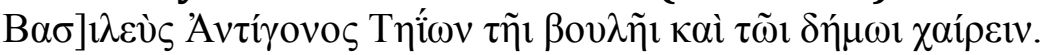

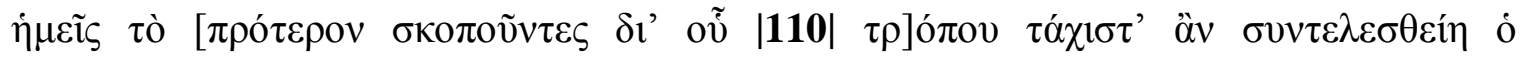

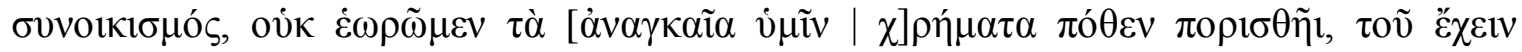

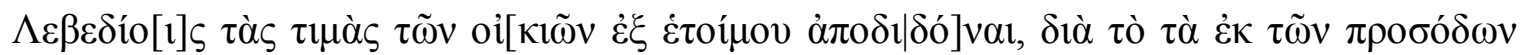

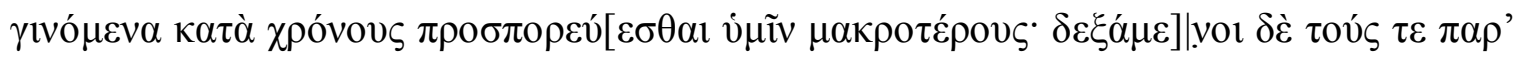

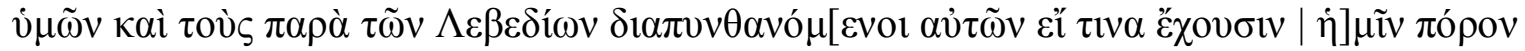

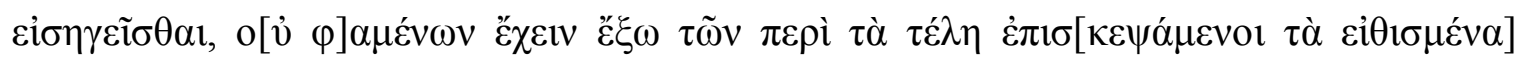

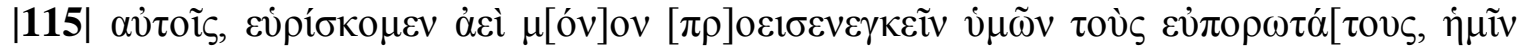

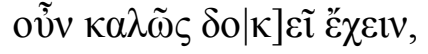

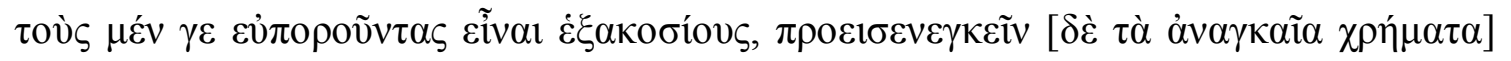

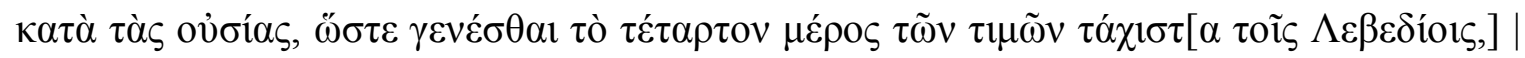

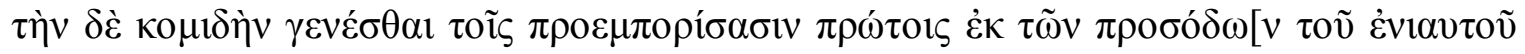

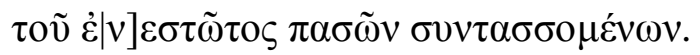

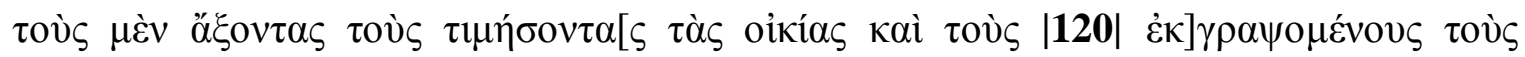

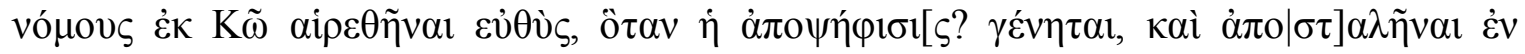

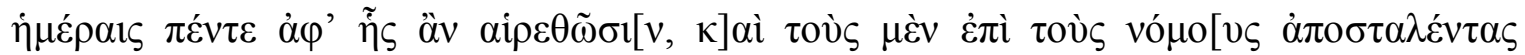

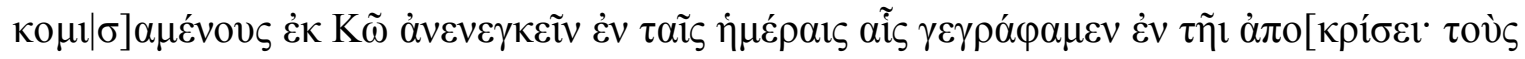

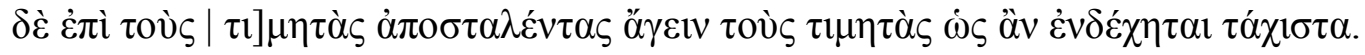

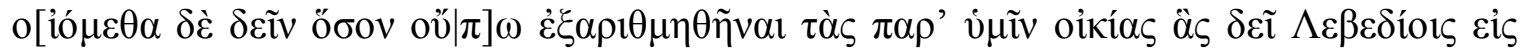

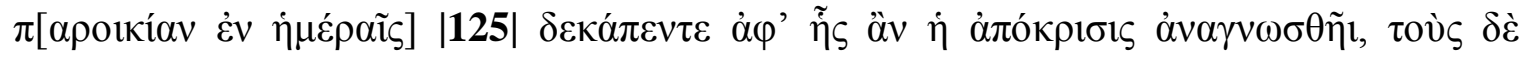

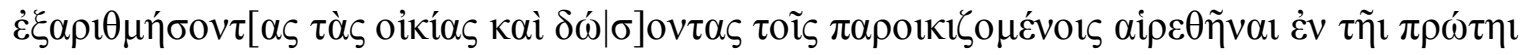

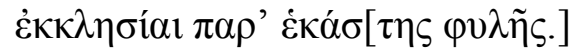


[Considering the earlier thing, by which] means the synoikism may be carried out, we did not see whence the [necessary money for you] would be provided, for the value of the houses held by the Lebedians [to be paid in cash-at-hand], because the money from income happens to come in over [too long] a time [for you]. We received envoys from you and from the Lebedians, inquiring [of them, if they had anything] to suggest to us. Since they did not mention anything other than dues, we investi[gated the arrangements] of them and we find that only your richest people ever pay these, [so it seems appropria]te that:

The rich are to be six hundred and are to pay [the necessary things], according to their property, so that the fourth part of the payment may be rendered [to the Lebedians] as soon as possible. The repayment is to be made to these payes first of all arrangements from the income [when the next year] has begun.

Those who will carry out the valuation of [the houses and] the transcription of the laws of Kōs are to be chosen immediately when the final vote [is done] and sent within five days from their selection. The men [sent] for the laws are to submit the laws brought from Kōs within the number of days which we have written in the ju[dgment. Those sent for the valuations] are to do the valuations as quickly as is possible.

We think it necessary that] it be determined [how many] of your houses are needed for [the Lebedians as temporary accommodation within] fifteen [days] from the reading of this judgment, and those determining [the number of houses needed and giv]ing them to the people who are to be temporarily accommodated are to be chosen at the first assembly of the nex[t phylē] 


\title{
Syll 560 : Magnēsia-on-the-Maiandros : c.200 BC (Part One)
}

\author{
$\pi \alpha \rho \alpha ̀$ 'E $\pi 1 \delta \alpha \mu v i ́ \omega v \cdot \mid$
}

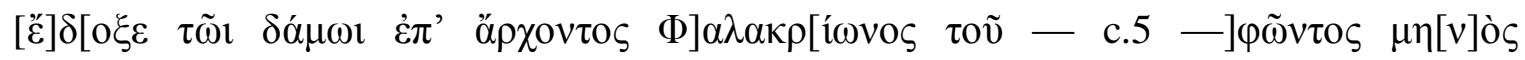
A $\lambda_{1}[0] \mid \tau \rho o \pi i ́ o v$.

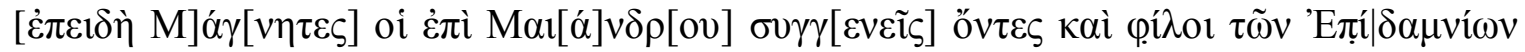

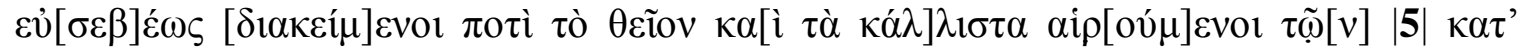

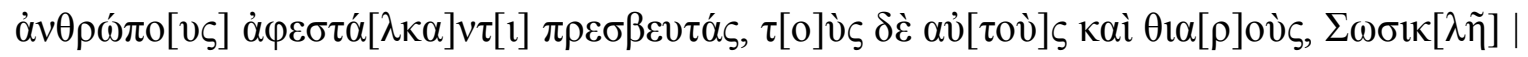

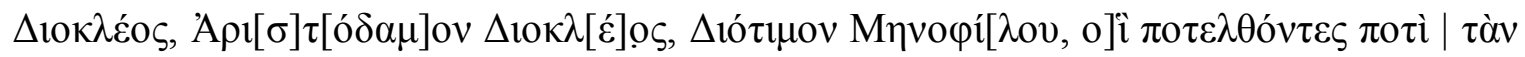

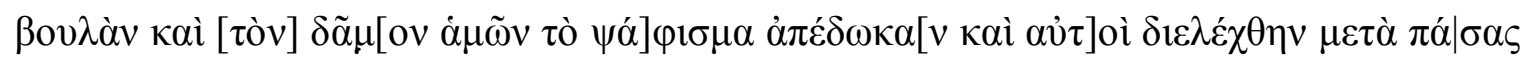

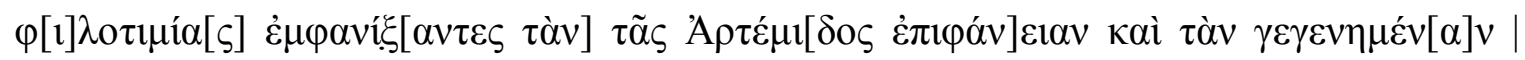

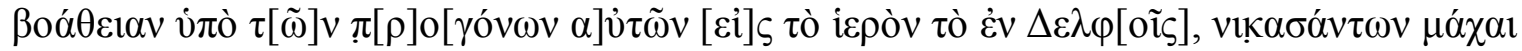

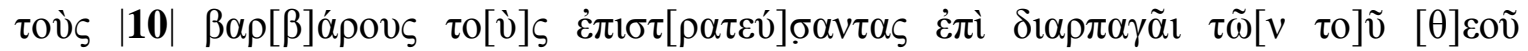

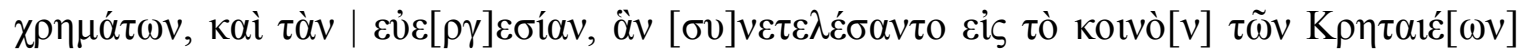

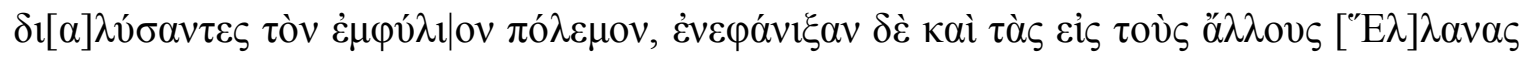

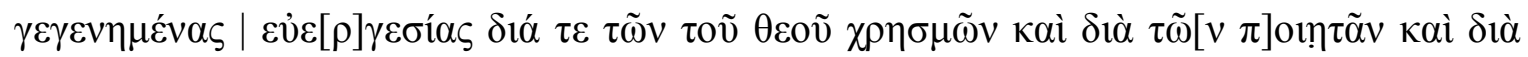

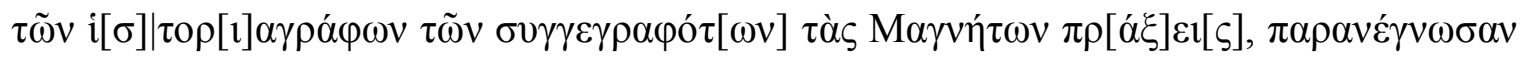

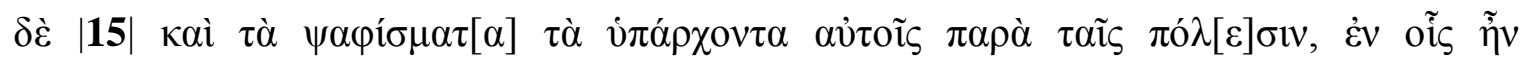

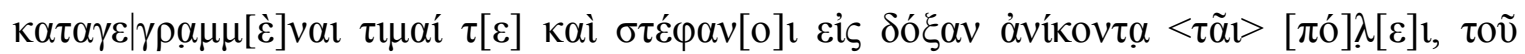

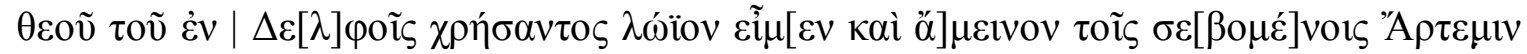

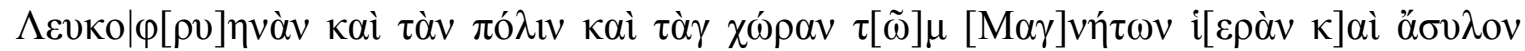

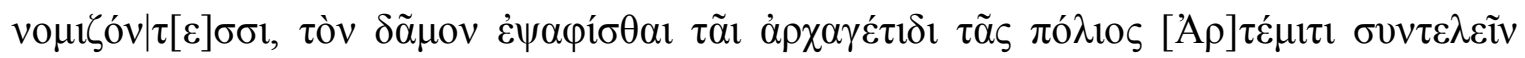

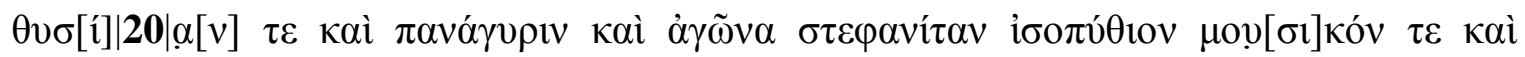

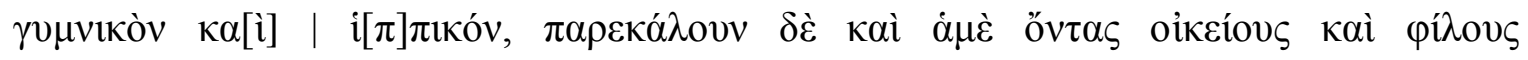

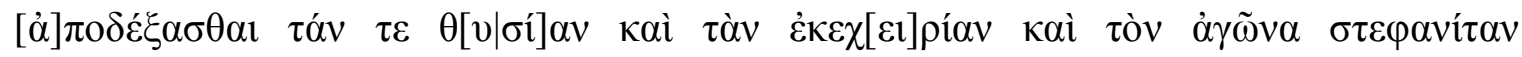

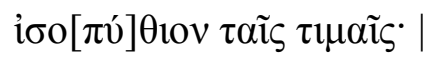




\section{From the Epidamnians}

It seemed [good to the damos ${ }^{610}$ in the archonship of $\mathrm{Ph}$ ]alakr[iōn son of — — ]phōn, in the month of Hali[o]tropios:

[Since the M]ag[nēsians] on the Mai[a]ndros are kin and friends of the Epidamnians, are pious to the divine and they chose the virtuous among them and sent them among men as ambassadors; these ambassadors and thiōroi ${ }^{611}$ were: Sōsik[lēs] son of Dioklēs, Arist[odam]os son of Dioklēs, Diotimos son of Mēnophi[los], who came to [our] boula ${ }^{612}$ and damos and delivered a decree [and th]ey spoke with distinction and explained their manifestation of Artemis and the help given by their ancestors to the temple at Delphi, when they defeated the barbarians, who were marching to plunder the goods of the god, in battle and the good deed which they carried out for the League of the Cretans [by] putting an end to the internecine war, and also announced the good deeds which have occurred for the other Greeks through the oracles of their god and through their poets and through the historians who have described the deeds of the Magnēsians, and they read out the decrees already sent to them from the poleis, in which were the honours written below and crowns for the glory belonging to their polis. When the god of Delphi proclaimed that it be more desirable and better for those who worship Artemis Leukoph[ry]ēna and recognise the polis and land of the Magnēsians as $\mathrm{h}[\mathrm{oly}]$ and inviolate, their damos voted to carry out sacrifices, festivities and Pythian-grade crown games in the arts, athletics and horseracing for Artemis the foundress of the polis and they summoned us as family and friends to recognise the sacrifices, the holiday and the Pythian-grade crown games with honours.

\footnotetext{
${ }^{610}$ Doric for demos

${ }^{611}$ Doric for theōroi.

${ }^{612}$ Doric for boule.
} 


\section{Syll 560 : Magnēsia-on-the-Maiandros : c.200 BC (Part Two)}

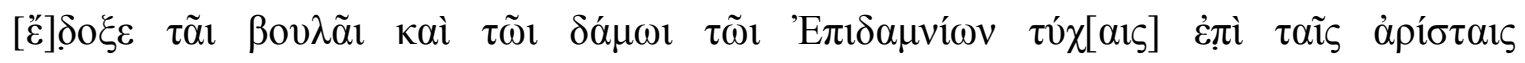

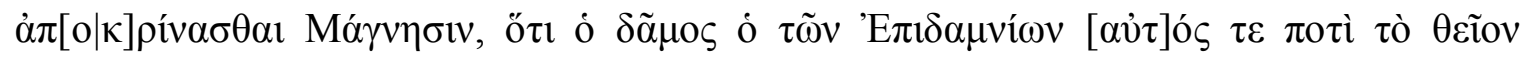

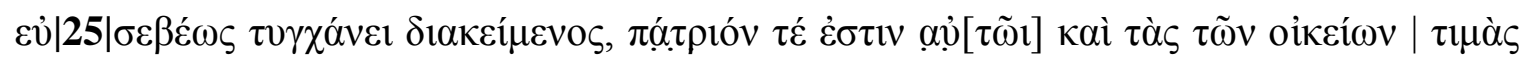

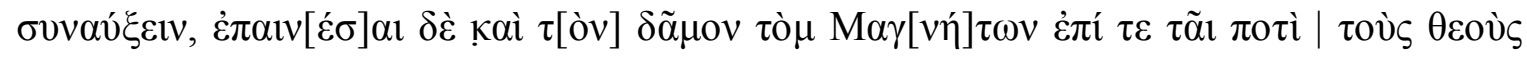

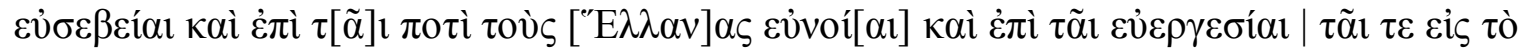

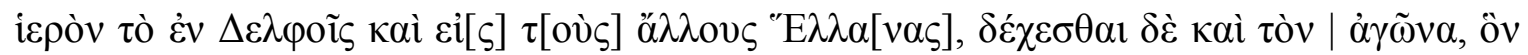

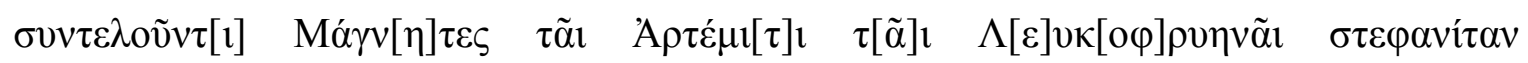

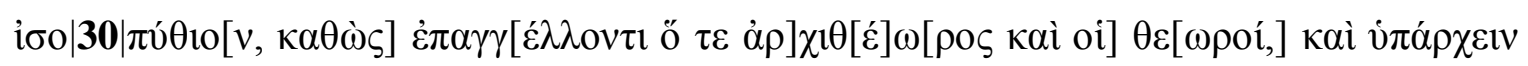

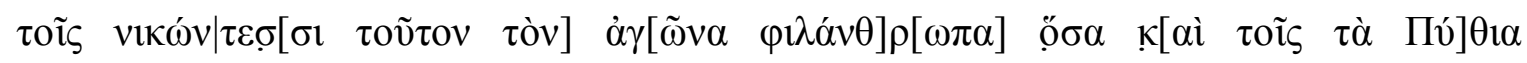

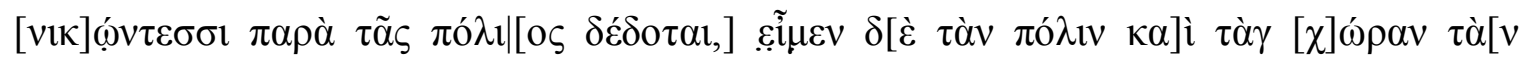

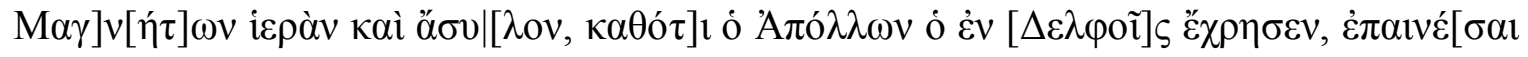

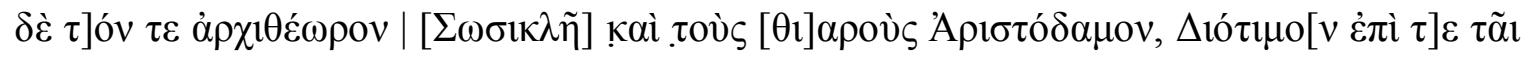

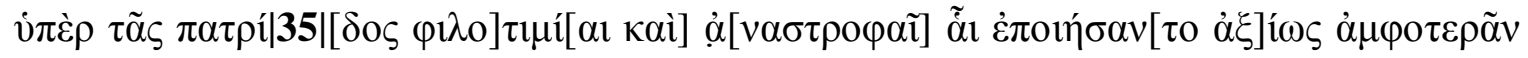

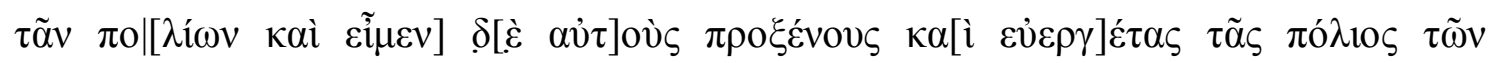

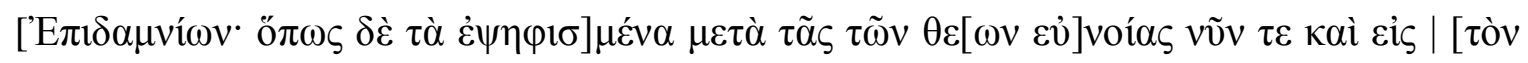

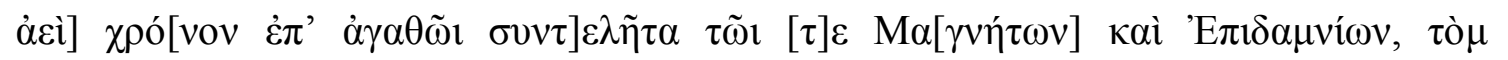

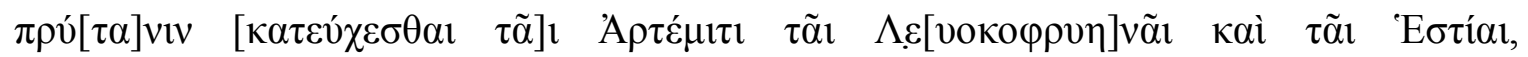

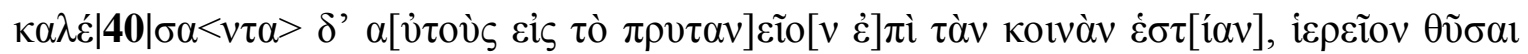

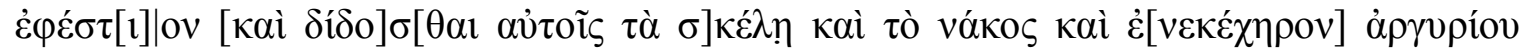

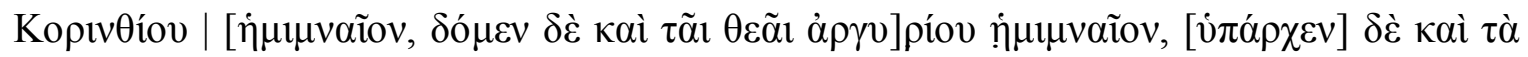

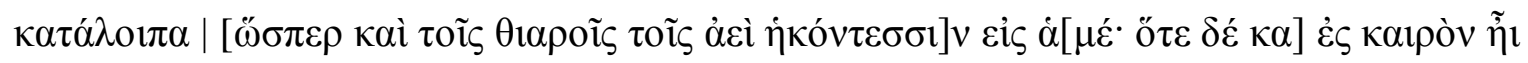

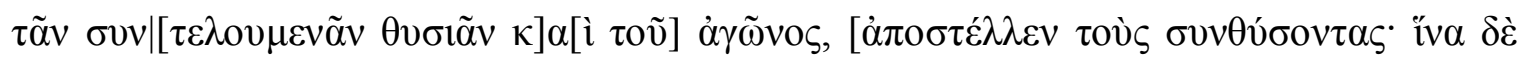

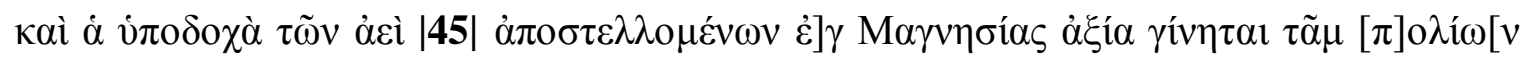

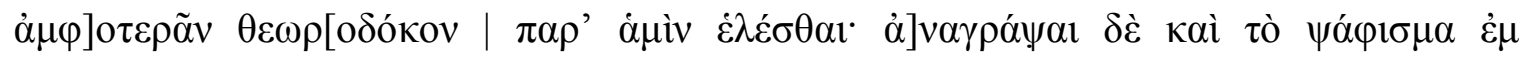

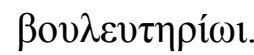


It seemed good to the boula and the damos of the Epidamnians:

- To answer the Magnēsians, in their excellent fortune, that the damos of the Epidamnians is pious to the divine and is able to augment the fatherland and the honours of the inhabitants,

- And to applaud the damos of the Magnēsians for their piety to the gods and for their goodwill to the [Greek]s and for their good deeds for the Temple at Delphi and the other Greeks,

- And to accept the Pythian-grade crown games which the Magnēsians hold for Artemis L[e]uk[oph]ryēna, just as was called for by the architheōros and the theōroi,

- And to take the initiative in granting victors of these games the same privileges as are [given by the] polis to [victors of the Py]thian games, and that the polis and land of the Magnēsians is holy and invio[late, just a]s Apollo at Delphi proclaimed

- And to applaud the architheōros Sōsiklēs and the [thi] Diotimos for their distinction on behalf of their fatherland and the behaviour, in which they showed themselves worthy of both po[leis] and they will be guestfriends and [bene]factors of the polis of the Epidamnians

- And so that the decrees about the games, with the goodwill of the gods, be maintained by the Ma[gnēsians] and the Epidamnians now and for all time, the prytany [vows to] Artemis Le[ukophryē]na and to Hestia, and calling [the thioroi into the prytan]eio[n], to the common hearth, sacrifices a holy victim by the hearth [and gi]v[es them the l]egs and the fleece and [a half-mina travel allowance] of Korinthian silver [and gave] a half-mina of sil[ver to the goddess], and everything else [was done, just as always happens when thiaroi come] to us.

- And whenever it is the time for the cele[bration of the sacrifices] and [the] games, [to send men to join in the sacrifices]

- [And so that the reception of those sent to] Magnēsia will always be worthy of both poleis, to choose a theōr[odokos from among us]

- And to inscribe the decree in the bouleuterrion. 


\section{APPENDIX TWO: COINS USED}

\section{Coin Catalogues}

Bellinger, A.R. 1949. The Excavations at Dura-Europus conducted by Yale University and the French Academy of Inscriptions and Letters: The Coins VI, edited by M. I. Rostovtzeff et al. New Haven, CT: Yale University Press.

BMC: Gardner, Percy. 1878. A Catalogue of Greek Coins: The Seleukid Kings of Syria in the British Museum. London: British Museum Press.

ESM: Newell, Edward Theodore. 1938. The Coinage of the Eastern Seleucid mints from Seleucus I to Antiochus III. New York, NY: American Numismatic Society.

GCS: Wroth, Warwick William. 1899. Catalogue of the Greek Coins of Galatia, Cappadocia and Syria. London: British Museum Press.

SC: Houghton, Arthur \& Catharine Lorber. 2002. Seleucid Coins: A Comprehensive Guide. New York, NY: American Numismatic Society.

SdT: Le Rider, Georges. 1998. Séleucie du Tigre: Les Monnaies Séleucides et Parthes. Florence : Casa Editrice Le Lettere.

WSM: Newell, Edward Theodore. 1941. The Coinage of the Western Seleucid Mints from Seleucus I to Antiochus III. New York, NY: American Numismatic Society, 1941.

There are two convenient online databases:

Kurth, Dane. WildWinds. http://www.wildwinds.com/

Department of Coins and Medals, The Fitzwilliam Museum. Sylloge Nummorum Graecorum. http://www.sylloge-nummorum-graecorum.org/ 
BMC: Gardner. 1878.

Catalogue of Greek Coins: The Seleukid Kings of Syria

Antiochus IV, page 34ff.

\begin{tabular}{|c|c|c|c|c|}
\hline BMC: & Mint & Issuer & Date (BC) & Denomination \\
\hline 38 & & Antiochos IV & $175-164$ & Bronze \\
\hline 39 & & Antiochos IV & $175-164$ & Bronze \\
\hline 40 & & Antiochos IV & $175-164$ & Bronze \\
\hline 41 & & Antiochos IV & $175-164$ & Bronze \\
\hline 42 & Egypt? & Antiochos IV & $175-164$ & Bronze \\
\hline 43 & & Antiochos IV & 175-164 & Bronze \\
\hline 44 & & Antiochos IV & $175-164$ & Bronze \\
\hline 45 & & Antiochos IV & $175-164$ & Bronze \\
\hline 46 & & Antiochos IV & $175-164$ & Bronze \\
\hline 47 & & Antiochos IV & $175-164$ & Bronze \\
\hline 48 & & Antiochos IV & $175-164$ & Bronze \\
\hline 49 & & Antiochos IV & 175-164 & Bronze \\
\hline 50 & Sidon & $\begin{array}{l}\text { Antiochos IV \& } \\
\text { Sidon }\end{array}$ & $175-164$ & Bronze \\
\hline 51 & Sidon & $\begin{array}{l}\text { Antiochos IV \& } \\
\text { Sidon }\end{array}$ & $175-164$ & Bronze \\
\hline 52 & Sidon & $\begin{array}{l}\text { Antiochos IV \& } \\
\text { Sidon }\end{array}$ & $175-164$ & Bronze \\
\hline 53 & Sidon & $\begin{array}{l}\text { Antiochos IV \& } \\
\text { Sidon }\end{array}$ & $175-164$ & Bronze \\
\hline 54 & Sidon & $\begin{array}{l}\text { Antiochos IV \& } \\
\text { Sidon }\end{array}$ & $175-164$ & Bronze \\
\hline 55 & Tyre & $\begin{array}{l}\text { Antiochos IV \& } \\
\text { Tyre }\end{array}$ & $175-164$ & Bronze \\
\hline 56 & Tyre & $\begin{array}{l}\text { Antiochos IV \& } \\
\text { Tyre }\end{array}$ & $175-164$ & Bronze \\
\hline 57 & $\begin{array}{l}\text { Laodikeia } \\
\text { in Koile } \\
\text { Syria }\end{array}$ & $\begin{array}{l}\text { Antiochos IV \& } \\
\text { Laodikeia }\end{array}$ & $175-164$ & Bronze \\
\hline 58 & Mopsos & Mopsos & 175-164 & Bronze \\
\hline 59 & $\begin{array}{l}\text { Hieropolis } \\
\text { Kyrrhestika }\end{array}$ & Hieropolis & $175-164$ & Bronze \\
\hline 60 & $\begin{array}{l}\text { Hieropolis } \\
\text { Kyrrhestika }\end{array}$ & Hieropolis & $175-164$ & Bronze \\
\hline 61 & Antioch & Antioch & 175-164 & Bronze \\
\hline 62 & Antioch & Antioch & $175-164$ & Bronze \\
\hline 63 & Antioch & Antioch & $175-164$ & Bronze \\
\hline 64 & Antioch & Antioch & $175-164$ & Bronze \\
\hline 65 & Antioch & Antioch & $175-164$ & Bronze \\
\hline
\end{tabular}


BMC: Gardner. 1878.

Catalogue of Greek Coins: The Seleukid Kings of Syria

Antiochus IV, page 34ff.

\begin{tabular}{|c|c|c|c|c|}
\hline BMC: & Mint & Issuer & Date (BC) & Denomination \\
\hline 66 & Antioch & Antioch & $175-164$ & Bronze \\
\hline 67 & Antioch & Antioch & 175-164 & Bronze \\
\hline 68 & Antioch & Antioch & $175-164$ & Bronze \\
\hline 69 & Antioch & Antioch & $175-164$ & Bronze \\
\hline 70 & Antioch & Antioch & $175-164$ & Bronze \\
\hline 71 & Antioch & Antioch & $175-164$ & Bronze \\
\hline 72 & $\begin{array}{l}\text { Ptolemais- } \\
\text { Ake }\end{array}$ & Ptolemais-Ake & $175-164$ & Bronze \\
\hline 73 & $\begin{array}{l}\text { Ptolemais- } \\
\text { Ake }\end{array}$ & Ptolemais-Ake & $175-164$ & Bronze \\
\hline 74 & $\begin{array}{l}\text { Antiocheia } \\
\text { in Kalliroe }\end{array}$ & $\begin{array}{l}\text { Antiocheia in } \\
\text { Kalliroe }\end{array}$ & $175-164$ & Bronze \\
\hline 75 & $\begin{array}{l}\text { Antiocheia } \\
\text { in Kalliroe }\end{array}$ & $\begin{array}{l}\text { Antiocheia in } \\
\text { Kalliroe }\end{array}$ & $175-164$ & Bronze \\
\hline 76 & $\begin{array}{l}\text { Antiocheia } \\
\text { in Kalliroe }\end{array}$ & $\begin{array}{l}\text { Antiocheia in } \\
\text { Kalliroe }\end{array}$ & $175-164$ & Bronze \\
\hline 77 & $\begin{array}{l}\text { Antiocheia } \\
\text { in Kalliroe }\end{array}$ & $\begin{array}{l}\text { Antiocheia in } \\
\text { Kalliroe }\end{array}$ & $175-164$ & Bronze \\
\hline 78 & $\begin{array}{l}\text { Antiocheia } \\
\text { in Kalliroe }\end{array}$ & $\begin{array}{l}\text { Antiocheia in } \\
\text { Kalliroe }\end{array}$ & $175-164$ & Bronze \\
\hline 79 & $\begin{array}{l}\text { Antiocheia } \\
\text { in Kalliroe }\end{array}$ & $\begin{array}{l}\text { Antiocheia in } \\
\text { Kalliroe }\end{array}$ & $175-164$ & Bronze \\
\hline 80 & $\begin{array}{l}\text { Antiocheia } \\
\text { in Kalliroe }\end{array}$ & $\begin{array}{l}\text { Antiocheia in } \\
\text { Kalliroe }\end{array}$ & $175-164$ & Bronze \\
\hline 81 & Apameia & Apameia & $175-164$ & Bronze \\
\hline 82 & $\begin{array}{l}\text { Laodikeia- } \\
\text { by-the-Sea }\end{array}$ & $\begin{array}{l}\text { Laodikeia-by- } \\
\text { the-Sea }\end{array}$ & $175-164$ & Bronze \\
\hline 83 & $\begin{array}{l}\text { Seleukeia } \\
\text { Pieria }\end{array}$ & $\begin{array}{l}\text { Seleukeia } \\
\text { Pieria }\end{array}$ & $175-164$ & Bronze \\
\hline 84 & $\begin{array}{l}\text { Seleukeia } \\
\text { Pieria }\end{array}$ & $\begin{array}{l}\text { Seleukeia } \\
\text { Pieria }\end{array}$ & $175-164$ & Bronze \\
\hline 85 & $\begin{array}{l}\text { Antiocheia } \\
\text { Mygdonia }\end{array}$ & $\begin{array}{l}\text { Antiocheia } \\
\text { Mygdonia }\end{array}$ & $175-164$ & Bronze \\
\hline
\end{tabular}


BMC: Gardner. 1878.

Catalogue of Greek Coins: The Seleukid Kings of Syria

BMC Alexander I, page 51ff.

\begin{tabular}{|c|c|c|c|c|}
\hline BMC: & Mint & Issuer & Date (BC) & Denomination \\
\hline 59 & Kyrrhos & Kyrrhos & 148 & Bronze \\
\hline 60 & Kyrrhos & Kyrrhos & 148 & Bronze \\
\hline 61 & Kyrrhos & Kyrrhos & 148 & Bronze \\
\hline 62 & Kyrrhos & Kyrrhos & 148 & Bronze \\
\hline 63 & Antioch & Antioch & $152-144$ & Bronze \\
\hline 64 & Apameia & Apameia & 147 & Bronze \\
\hline 65 & Apameia & Apameia & 147 & Bronze \\
\hline 66 & $\begin{array}{l}\text { Laodikeia - } \\
\text { by-the-Sea }\end{array}$ & $\begin{array}{l}\text { Laodikeia -by- } \\
\text { the-Sea }\end{array}$ & $152-144$ & Bronze \\
\hline 67 & $\begin{array}{l}\text { Laodikeia - } \\
\text { by-the-Sea }\end{array}$ & $\begin{array}{l}\text { Laodikeia -by- } \\
\text { the-Sea }\end{array}$ & $152-144$ & Bronze \\
\hline 68 & $\begin{array}{l}\text { Seleukeia } \\
\text { Pieria }\end{array}$ & $\begin{array}{l}\text { Seleukeia } \\
\text { Pieria }\end{array}$ & 146 & Bronze \\
\hline 69 & $\begin{array}{l}\text { Seleukeia } \\
\text { Pieria }\end{array}$ & $\begin{array}{l}\text { Seleukeia } \\
\text { Pieria }\end{array}$ & 146 & Bronze \\
\hline
\end{tabular}

GCS: Wroth. 1899.

Catalogue of the Greek Coins of Galatia, Cappadocia and Syria.

Antioch on the Orontes, page 151ff.

\begin{tabular}{|l|l|l|l|l|}
\hline GCS: & Mint & Issuer & Date (BC) & Denomination \\
\hline 1 & Antioch & Antioch & 149 & Bronze \\
\hline 2 & Antioch & Antioch & 149 & Bronze \\
\hline 3 & Antioch & Antioch & 149 & Bronze \\
\hline 4 & Antioch & Antioch & 148 & Bronze \\
\hline 5 & Antioch & Antioch & 148 & Bronze \\
\hline 6 & Antioch & Antioch & 148 & Bronze \\
\hline 7 & Antioch & Antioch & 148 & Bronze \\
\hline 8 & Antioch & Antioch & 148 & Bronze \\
\hline 9 & Antioch & Antioch & 148 & Bronze \\
\hline 10 & Antioch & Antioch & 147 & Bronze \\
\hline 11 & Antioch & Antioch & 147 & Bronze \\
\hline
\end{tabular}


SC: Houghton \& Lorber. 2002.

Seleucid Coins: A Comprehensive Guide.

\begin{tabular}{|c|c|c|c|c|c|}
\hline SC\# & Mint & Issuer & Date (BC) & Denomination & Concordance \\
\hline 6 & Sardis & Seleukos I & $282-281$ & Bronze & $\begin{array}{l}\text { WSM1357a-g } \\
\text { WSM1627-8 }\end{array}$ \\
\hline 14 & Antioch & Seleukos I & $300-281$ & Silver Hemiobol & \\
\hline 35 & Apameia & Seleukos I & $300-281$ & Bronze & WSM1128 \\
\hline 36 & Laodikeia-by-the-Sea & Seleukos I & $300-281$ & Silver Tetradrachm & WSM1202-4 \\
\hline 37 & Laodikeia-by-the-Sea & Seleukos I & $300-281$ & Silver Drachm & \\
\hline 38 & Bambyke & $\begin{array}{l}\text { Seleukos I? } \\
\text { Bambyke? }\end{array}$ & $298-294$ & Silver Obol & \\
\hline 200 & Ekbatana & Seleukos I & $311-281$ & Gold Stater & $\begin{array}{l}\text { ESM428 } \\
\text { ESM433 } \\
\text { ESM438 } \\
\text { ESM458 } \alpha-\beta \\
\text { ESM463 } \\
\text { ESM472 }\end{array}$ \\
\hline 201 & Ekbatana & Seleukos I & $311-281$ & Gold Stater & ESM499 \\
\hline 202 & Ekbatana & Seleukos I & $311-295$ & Silver Tetradrachm & $\begin{array}{l}\text { ESM429 } \\
\text { ESM443 } \\
\text { ESM446-7 } \\
\text { ESM453-4 } \\
\text { ESM457 } \\
\text { ESM464 } \\
\text { ESM473 } \\
\text { ESM475 } \\
\text { ESM485 } \\
\text { ESM491 }\end{array}$ \\
\hline 203 & Ekbatana & Seleukos I & 295 & Silver Tetradrachm & ESM475 \\
\hline
\end{tabular}


SC: Houghton \& Lorber. 2002.

Seleucid Coins: A Comprehensive Guide.

\begin{tabular}{|c|c|c|c|c|c|}
\hline SC\# & Mint & Issuer & Date (BC) & Denomination & Concordance \\
\hline 204 & Ekbatana & Seleukos I & $295-281$ & Silver Tetradrachm & $\begin{array}{l}\text { ESM480; } \\
\text { ESM484; } \\
\text { ESM492; } \\
\text { ESM493; } \\
\text { ESM496; } \\
\text { ESM497; } \\
\text { ESM498; } \\
\text { ESM500; } \\
\text { ESM503; } \\
\text { ESM506 }\end{array}$ \\
\hline 205 & Ekbatana & Seleukos I & $295-281$ & Silver Tetradrachm & $\begin{array}{l}\text { ESM508; } \\
\text { ESM510; } \\
\text { ESM512 }\end{array}$ \\
\hline 206 & Ekbatana & Seleukos I & $311-281$ & Silver Didrachm & $\begin{array}{l}\text { ESM435; } \\
\text { ESM448; } \\
\text { ESM465; } \\
\text { ESM476 }\end{array}$ \\
\hline 207 & Ekbatana & Seleukos I & $311-281$ & Silver Didrachm & WSM480A \\
\hline 208 & Ekbatana & Seleukos I & 311-295 & Silver Drachm & $\begin{array}{l}\text { ESM444 } \\
\text { ESM449 } \\
\text { ESM458 } \\
\text { ESM466 } \\
\text { ESM474 } \\
\text { ESM477 }\end{array}$ \\
\hline 209 & Ekbatana & Seleukos I & 295 & Silver Drachm & ESM481 \\
\hline 210 & Ekbatana & Seleukos I & $295-281$ & Silver Drachm & $\begin{array}{l}\text { ESM488 } \\
\text { WSM507A }\end{array}$ \\
\hline 211 & Ekbatana & Seleukos I & $295-281$ & Silver Drachm & $\begin{array}{l}\text { ESM507 } \\
\text { ESM511 } \\
\text { ESM514 } \\
\text { ESM515 }\end{array}$ \\
\hline
\end{tabular}


SC: Houghton \& Lorber. 2002.

Seleucid Coins: A Comprehensive Guide.

\begin{tabular}{|c|c|c|c|c|c|}
\hline SC\# & Mint & Issuer & Date (BC) & Denomination & Concordance \\
\hline 212 & Ekbatana & Seleukos I & 311-295 & Silver Hemidrachm & $\begin{array}{l}\text { ESM430 } \\
\text { ESM436 } \\
\text { ESM441 } \\
\text { ESM450 } \\
\text { ESM467 } \\
\text { ESM478 } \\
\text { ESM494 }\end{array}$ \\
\hline 213 & Ekbatana & Seleukos I & 295 & Silver Hemidrachm & ESM482 \\
\hline 214 & Ekbatana & Seleukos I & $295-281$ & Silver Hemidrachm & $\begin{array}{l}\text { ESM483 } \\
\text { ESM489 } \\
\text { ESM505 }\end{array}$ \\
\hline 215 & Ekbatana & Seleukos I & $295-281$ & Silver Hemidrachm & \\
\hline 216 & Ekbatana & Seleukos I & $311-281$ & Silver Obol & $\begin{array}{l}\text { ESM431 } \\
\text { ESM437 } \\
\text { ESM451 } \\
\text { ESM468 } \\
\text { ESM471 } \\
\text { ESM479 } \\
\text { ESM495 }\end{array}$ \\
\hline 290 & Ai Khanoum & Seleukos I & $285-281$ & Bronze & \\
\hline 330 & Tarsos & Antiochos I & $281-260$ & Silver Tetradrachm & WSM1294 \\
\hline 332.1 & Tarsos & Antiochos I & $281-260$ & Bronze & WSM1299 \\
\hline 335 & Antioch & Antiochos I & $281-260$ & Silver Tetradrachm & $\begin{array}{l}\text { WSM937 } \\
\text { WSM939 } \\
\text { WSM938 } \\
\text { WSM940 } \\
\text { WSM941 } \\
\text { WSM957 } \\
\text { WSM958 }\end{array}$ \\
\hline 339 & Antioch & Antiochos I & 270s? & Bronze & $\begin{array}{l}\text { WSM942-4 } \\
\text { WSM946 }\end{array}$ \\
\hline 363 & Doura-Eurōpos & Antiochos I & $281 ?$ & Bronze & WSM878 \\
\hline
\end{tabular}


SC: Houghton \& Lorber. 2002.

Seleucid Coins: A Comprehensive Guide.

\begin{tabular}{|c|c|c|c|c|c|}
\hline SC\# & Mint & Issuer & Date (BC) & Denomination & Concordance \\
\hline 364 & Doura-Eurōpos & Antiochos I & $281 ?$ & Bronze & WSM879 \\
\hline 365 & Doura-Eurōpos & Antiochos I & $281 ?$ & Bronze & WSM880 \\
\hline 366 & Doura-Eurōpos & Antiochos I & $281 ?$ & Bronze & WSM881 \\
\hline 367 & Doura-Eurōpos & Antiochos I & $281 ?$ & Bronze & WSM882 \\
\hline 368 & Doura-Eurōpos & Antiochos I & $281 ?$ & Bronze & WSM883 \\
\hline 481 & Lysimacheia & Antiochos II & $261-246$ & Silver Tetradrachm & \\
\hline 482 & Lysimacheia & Antiochos II & $261-246$ & Silver Tetradrachm & WSM1610-3 \\
\hline 483 & Lysimacheia & Antiochos II & $261-246$ & Silver Tetradrachm & WSM1616-20 \\
\hline 488 & Ilion & Antiochos II & $261-246$ & Silver Tetradrachm & WSM1560 \\
\hline 517 & Sardis & Antiochos II & $261-246$ & Gold Stater & \\
\hline 518 & Sardis & Antiochos II & $261-246$ & Silver Tetradrachm & WSM1385-8 \\
\hline 519 & Sardis & Antiochos II & $261-246$ & Silver Tetradrachm & WSM1406 \\
\hline 520 & Sardis & Antiochos II & $261-246$ & Bronze & WSM1379-81 \\
\hline 521 & Sardis & Antiochos II & $261-246$ & Bronze & WSM1382-3 \\
\hline 522 & Sardis(b) & Antiochos II & $261-246$ & Bronze & $\begin{array}{l}\text { WSM1389-91 } \\
\text { WSM1395-6 } \\
\text { WSM1398-9 } \\
\text { WSM1403 } \\
\text { WSM1405 }\end{array}$ \\
\hline 523 & Sardis(b) & Antiochos II & $261-246$ & Bronze & WSM1404 \\
\hline 524 & Sardis(b) & Antiochos II & $261-246$ & Bronze & \\
\hline 525 & Sardis(b) & Antiochos II & $261-246$ & Bronze & $\begin{array}{l}\text { WSM1407 } \\
\text { WSM1409-11 } \\
\text { WSM1413 }\end{array}$ \\
\hline 526 & Sardis(b) & Antiochos II & $261-246$ & Bronze & WSM1412 \\
\hline
\end{tabular}


SC: Houghton \& Lorber. 2002.

Seleucid Coins: A Comprehensive Guide.

\begin{tabular}{|c|c|c|c|c|c|}
\hline SC\# & Mint & Issuer & Date (BC) & Denomination & Concordance \\
\hline \multirow[t]{2}{*}{527} & Sardis(b) & Antiochos II & $261-246$ & Bronze & WSM1400 \\
\hline & & & & & WSM1402 \\
\hline \multirow[t]{4}{*}{528} & Sardis(b) & Antiochos II & $261-246$ & Bronze & WSM1392 \\
\hline & & & & & WSM1397 \\
\hline & & & & & WSM1401 \\
\hline & & & & & WSM1408 \\
\hline 529 & Sardis(b) & Antiochos II & $261-246$ & Bronze & \\
\hline 530 & Sardis(b) & Antiochos II & $261-246$ & Bronze & WSM1384 \\
\hline 531 & Sardis(b) & Antiochos II & $261-246$ & Bronze & \\
\hline \multirow[t]{3}{*}{571} & Antioch & Antiochos II & $261-246$ & Silver Tetradrachm & WSM970-2 \\
\hline & & & & & WSM975 \\
\hline & & & & & WSM980 \\
\hline 572 & Antioch & Antiochos II & $261-246$ & Bronze & WSM967 \\
\hline \multirow[t]{2}{*}{576} & Laodikeia-by-the-Sea & Antiochos II & $261-246$ & Silver Tetradrachm & WSM1219 \\
\hline & & & & & WSM1221-6 \\
\hline 873 & Alexandreia Troas & $\begin{array}{l}\text { Antiochus } \\
\text { Hierax }\end{array}$ & $242-227$ & Gold Stater & \\
\hline \multirow[t]{2}{*}{874} & Alexandreia Troas & Antiochus & $242-227$ & Silver Tetradrachm & WSM1561 \\
\hline & & Hierax & & & WSM1565 \\
\hline \multirow[t]{2}{*}{875} & Alexandreia Troas & Antiochus & $242-227$ & Silver Tetradrachm & WSM1567-72 \\
\hline & & Hierax & & & WSM1574 $\alpha$ \\
\hline \multirow[t]{2}{*}{876} & Alexandreia Troas & Antiochus & $242-227$ & Silver Tetradrachm & WSM1573 \\
\hline & & Hierax & & & WSM1574 $\beta$ \\
\hline 877 & Alexandreia Troas & $\begin{array}{l}\text { Antiochus } \\
\text { Hierax }\end{array}$ & $242-227$ & Silver Tetradrachm & WSM1580-4 \\
\hline 878 & Alexandreia Troas & $\begin{array}{l}\text { Antiochus } \\
\text { Hierax }\end{array}$ & $242-227$ & Silver Tetradrachm & WSM1575-9 \\
\hline 879 & AlexandreiaTroas & $\begin{array}{l}\text { Antiochus } \\
\text { Hierax }\end{array}$ & $242-227$ & Silver Tetradrachm & WSM1585-7 \\
\hline
\end{tabular}


SC: Houghton \& Lorber. 2002.

Seleucid Coins: A Comprehensive Guide.

\begin{tabular}{|c|c|c|c|c|c|}
\hline SC\# & Mint & Issuer & Date (BC) & Denomination & Concordance \\
\hline 880 & AlexandreiaTroas & $\begin{array}{l}\text { Antiochus } \\
\text { Hierax }\end{array}$ & $242-227$ & Silver Tetradrachm & WSM1588 \\
\hline 881 & AlexandreiaTroas & $\begin{array}{l}\text { Antiochus } \\
\text { Hierax }\end{array}$ & $242-227$ & Silver Tetradrachm & \\
\hline 882 & AlexandreiaTroas & $\begin{array}{l}\text { Antiochus } \\
\text { Hierax }\end{array}$ & $242-227$ & Silver Tetradrachm & WSM1589-91 \\
\hline 883 & AlexandreiaTroas & $\begin{array}{l}\text { Antiochus } \\
\text { Hierax }\end{array}$ & $242-227$ & Silver Tetradrachm & \\
\hline 884 & AlexandreiaTroas? & $\begin{array}{l}\text { Antiochus } \\
\text { Hierax }\end{array}$ & $242-227$ & Silver Tetradrachm & \\
\hline 885 & AlexandreiaTroas? & $\begin{array}{l}\text { Antiochus } \\
\text { Hierax }\end{array}$ & $242-227$ & Silver Tetradrachm & \\
\hline 886 & AlexandreiaTroas? & $\begin{array}{l}\text { Antiochus } \\
\text { Hierax }\end{array}$ & $242-227$ & Silver Tetradrachm & WSM1592 \\
\hline 927 & Arados & Arados & $226-223$ & Silver Tetradrachm & \\
\hline 949 & Seleukeia-Tigris & Molon & $222-220$ & Gold Stater & ESM225-8 \\
\hline 950 & Susa & Molon & $222-220$ & Silver Tetradrachm & \\
\hline 951 & Ekbatana & Molon & $222-220$ & Bronze & ESM574 \\
\hline 952 & Sardis & Achaios & $220-214$ & Gold Stater & WSM1439 \\
\hline
\end{tabular}




\section{BIBLIOGRAPHY}

Aalders, G.J.D. 1975. Political Thought in Hellenistic Times. Amsterdam: Adolf M. Hakkert.

Adams, Robert McC. 1965. Land Behind Baghdad: A History of Settlement on the Diyala Plains. Chicago, IL: University of Chicago Press.

Ager, Sheila. 1991. “A Royal Arbitration between Klazomenai and Teos?" Zeitschrift für Papyrologie und Epigraphik 85: 87-97. . 1996. Interstate Arbitrations in the Greek World 337 - 90 BC. Berkeley, CA:
University of California Press.

. 1998. "Civic Identity in the Hellenistic World: The Case of Lebedos." Greek, Roman \& Byzantine Studies 39(1): 5-21.

—. 2006. "The Power of Excess: Royal Incest \& the Ptolemaic Dynasty." Anthropologica 48(2): 165-186.

Anagnostou-Laoutides, Eva. 2012. "Zeus and Apollo in the Religious Program of Seleucus Nicator and Antiochus I" in ASCS 33 Selected Proceedings, edited by Eva Anagnostou-Laoutides. Sydney, NSW: Australasian Society for Classical Studies. www.ascs.org.au/ news/ascs33/index.html.

Aperghis, G.G. 2004. The Seleukid Royal Economy: The Finances and Financial Administration of the Seleukid Empire. Cambridge: Cambridge University Press.

—. 2005. "City Building \& the Seleukid Royal Economy" in Making, Moving \& Managing: The New World of Ancient Economics 323-31 BC, edited by Zofia H. Archibald, John K. Davies \& Vincent Gabrielsen. Oxford: Oxbow Books: 27-43.

Austin, M. M. \& P. Vidal-Naquet, 1977. Economic \& Social History of Ancient Greece: An Introduction, translated by M.M. Austin. Berkeley, CA: University of California Press.

Badian, Ernst. 1968. “A King's Notebooks.” Harvard Studies in Classical Philology 72: 183-204.

Bagnall, Roger S. 1976. The Administration of the Ptolemaic Possessions outside Egypt. Leiden: E J Brill.

Bagnall, Roger S. \& Peter Derow. 2004. Historical Sources in Translation: The Hellenistic Period. 2nd Ed. Malden, MA: Blackwell Publishing.

Bar-Kochva, Bezalel. 1976. The Seleucid Army: Organization \& Tactics in the Great Campaigns. Cambridge: Cambridge University Press.

Bell, Andrew. 2004. Spectacular Power in the Greek \& Roman City. Oxford: Oxford University Press. 
Bellinger, A.R. 1949. The Excavations at Dura-Europus conducted by Yale University and the French Academy of Inscriptions and Letters: The Coins VI, edited by M. I. Rostovtzeff et al.. New Haven, CT: Yale University Press.

Berthold, Richard M. 1984. Rhodes in the Hellenistic Age. Ithaca, NY: Cornell University Press.

Bevan, Edwyn Robert. 1901. "The Deification of Kings in the Greek Cities." The English Historical Review 16(64): 625-639.

1902. The House of Seleucus. London: Routledge \& Kegan Paul.

Bikerman, E. 1938. Institutions des Séleucides. Paris: Librairie Orientaliste Paul Geuthner.

Billows, Richard A. 1990. Antigonos the One-Eyed and the Creation of the Hellenistic State. Berkeley, CA: University of California Press.

Brill.

1995. Kings and Colonists: Aspects of Macedonian Imperialism. Leiden: E. J.

2003. "Cities" in A Companion to the Hellenistic World, edited by Andrew Erskine. Malden, MA: Blackwell Publishing: 196-214.

Bivar, A.D.H. 1978. "The Aramaic Summary" in Pasargadae: A Report on the Excavations Conducted by the British Institute of Persian Studies from 1961 to 1963, edited by David Stronach. Oxford: Clarendon Press: 161-162.

Boardman, John. 2002. "Greeks \& Syria: Pots \& People" in Greek Settlements in the Eastern Mediterranean \& the Black Sea, edited by G.R. Tsetskhladze \& A.M. Snodgrass. Oxford: Archaeopress: 1-16.

Bodel, John. 2001. "Epigraphy \& the Ancient Historian," in Epigraphic Evidence: Ancient History from Inscriptions, edited by John Bodel. London: Routledge.

Boiy, Tom. 2004. Late Achaemenid \& Hellenistic Babylon. Leuven: Peeters.

- 2011. "The Reigns of the Seleucid Kings According to the Babylonian King List." Journal of Near Eastern Studies 70(1): 1-12.

Bosworth, A.B. 1992. "Autonomia: The Use \& Abuse of Political Terminology." Studi Italiani di Filologia Classica $3^{\text {rd }}$ S. 10(1): 122-153.

- 2002. The Legacy of Alexander: Politics, Warfare, Propaganda under the Successors. Oxford: Oxford University Press.

Bothmer, Bernard V. 1952. "Ptolemaic Reliefs. II. Temple Decorations of Ptolemy Soter." Bulletin of the Museum of Fine Arts 50(281): 49-56.

Bremer, Jan N. 2012. "Athenian Civic Priests from Classical Times to Late Antiquity: Some Considerations" in Civic Priest Cult Personnel in Athens from the Hellenistic Period to Late Antiquity, edited by Marietta Horster \& Anja Klöcher. Berlin: Walter de Gruyter: 219-238. 
Briant, Pierre. 1990. "The Seleucid Kingdom, the Achaemenid Empire and the History of the Near East in the First Millennium BC" in Religion \& Religious Practice in the Seleucid Kingdom, edited by Per Bilde, Troels Engberg, Lise Hannestad, \& Jan Zahle. Aarhus: Aarhus University Press.

Bringmann, Klaus. 1993. "The King as Benefactor: Some Remarks on Ideal Kingship in the Age of Hellenism" in Images \& Ideologies: Self-Definition in the Hellenistic World, edited by Anthony Bulloch, Erich Gruen, A.A. Long \& Andrew Stuart. Berkeley, CA: University of California Press: 7-24.

2001. "Grain, Timber and Money: Hellenistic Kings, Finance, Buildings and Foundations in Greek Cities" in Hellenistic Economies, edited by Zofia H. Archibald, John Davies, Vincent Gabrielsen \& G.J. Oliver. London: Routledge: 205-214.

Burkert, Walter. 1995. "Greek Poleis and Civic Cults: Some Further Thoughts." Historia Einzelschriften 95: 201-210.

Buraselis, Kostas. 1993. "Ambivalent Roles of Centre and Periphery: Remarks on the Relation of the Cities of Greece with the Ptolemies until the End of Philometor's Age" in Centre and Periphery in the Hellenistic World, edited by Per Bilde et al.. Aarhus: Aarhus University Press: 251-270.

Burstein, Stanley Mayer. 1976. Outpost of Hellenism: The Emergence of Heraclea on the Black Sea. Berkeley, CA: University of California Press.

Capdetrey, Laurent. 2007. Le pouvoir séleucide : Territoire, administration, finances d'un royaume hellénistique (312-129 avant J.C.). Rennes: Presses Universitaires de Rennes.

Carlsson, Susanne. 2010. Hellenistic Democracies: Freedom, Independence and Political Procedure in Some East Greek City-States. Stuttgart: Franz Steiner Verlag.

Carney, Elizabeth. 2002. "Hunting \& the Macedonian Elite: Sharing the Rivalry of the Chase (Arrian 4.13.1)," in The Hellenistic World: New Perspectives, edited by Ogden, Daniel. Swansea: The Classical Press of Wales: 59-80.

Cartledge, Paul \& Antony Spawforth. 2002. Hellenistic \& Roman Sparta: A Tale of Two Cities. $2^{\text {nd }}$ Ed. London: Routledge.

Chaniotis, Angelos. 2003. "The Divinity of Hellenistic Rulers" in A Companion to the Hellenistic World, edited by Andrew Erskine. Malden, MA: Blackwell Publishing: 431-445.

. 2005. War in the Hellenistic World. Malden, MA: Blackwell Publishing.

. 2011. "The Ithyphallic Hymn for Demetrios Poliorketes \& Hellenistic Reigious Mentality," in More than Men, Less than Gods: Studies on Royal Cult \& Imperial Worship, edited by Panagiotis Iossif, Andrzej Chanowski \& Catharine Lorber. Leuven: Peeters: 157-195.

Clark, Graeme. W. 2002a. "The Governors' Palace, Acropolis." in Jebel Khalid on the Euphrates: Report on Excavations 1986-1996, edited by Graeme W. Clark et al. Sydney, NSW: Meditarch: 25-48 
2002b. "Four Hellenistic Seal Impressions" in Jebel Khalid on the Euphrates: Report on Excavations 1986-1996, edited by Graeme W. Clark et al.. Sydney, NSW: Meditarch: 202-204.

Cohen, Getzel M. 1978. The Seleucid Colonies: Studies in Founding, Administration, and Organization. Wiesbaden: Franz Steiner Verlag.

$$
\text { 41-50. }
$$

1991. "Katoikia, Katoikoi and Macedonians in Asia Minor." Ancient Society 22:

2006. The Hellenistic Settlements in Syria, the Red Sea Basin and North Africa. Berkeley, CA: University of California Press.

Cook, B.F. 1987. Greek Inscriptions. London: British Museum Press.

Cotton, Hannah M. \& Michael Wörrle. 2007. "Seleukos IV to Heliodoros: A New Dossier of Royal Correspondence from Israel." Zeitschrift für Papyrologie und Epigraphik 159: 191-205.

Davies, John K. 1994. "On the Non-Usability of 'Sovereignty' in an Ancient Greek Context," in Federazioni e federalism nell'Europa antica, Luciana Aigner Foresti et al.. Milan: Vita e Pensiero: 51-66.

. 2002. "The Interpenetration of Hellenistic Sovereignties," in The Hellenistic World: New Perspectives, edited by Ogden, Daniel. Swansea: The Classical Press of Wales: $1-22$

Delia, Diana. 1993. "Response" in Hellenistic History and Culture, edited by Peter Green. Berkeley, CA: University of California Press.

Derow P.S. 1993. “Antigonos the One-Eyed.” The Classical Review 43(2): 326-332.

Develin, R. 1990. "Numeral Corruption in Greek Historical Texts." Phoenix 44(1): 31-45.

Dmitriev, Sviatoslav. 2005. City Government in Hellenistic and Roman Asia Minor. Oxford: Oxford University Press.

- 2011. The Greek Slogan of Freedom and Early Roman Politics in Greece. Oxford: Oxford University Press.

Doty, Timothy Lawrence. 1977. Cuneiform Documents from Hellenistic Uruk. PhD diss., Yale University.

Downey, Glanville A. 1941. "The Seleucids: The Theory of Monarchy" in The Greek Political Experience: Studies in Honor of William Kelly Prentice. New York, NY: Russell \& Russell: 162-172.

- 1951. "The Occupation of Syria by the Romans." Transactions \& Proceedings of the American Philological Association 82: 149-163.

. 1958. "The Size of the Population of Antioch." Transactions \& Proceedings of the American Philological Association 89: 84-91.

1961. A History of Antioch in Syria from Seleucus to the Arab Conquest. Princeton, NJ: Princeton University Press. 
Duff, Tim. 1999. Plutarch's Lives: Exploring Virtue \& Vice. Oxford: Oxford University Press.

Dundas, Gregory S. 2002. "Augustus \& the Kingship of Egypt." Historia: Zeitschrift für Alte Geschichte 51(4): 433-448.

Dunn, Charlotte. 2012. Alexander's Image in the Propaganda of the Diadochoi. MA diss., Otago University.

Eddy, Samuel K. 1961. The King is Dead: Studies in Near Eastern Resistance to Hellenism 334 - 31 B.C. Lincoln, NE: University of Nebraska Press.

Edson, Charles. 1958. "Imperium Macedonicum: The Seleucid Empire and the Literary Evidence.” Classical Philology 53(3): 153-170.

Ehrenberg, Victor. The Greek State. $2^{\text {nd }}$ Ed. London: Methuen \& Co, 1969.

Elderkin, George W., Richard Stillwell \& D.B. Waage. 1934-1972. Antioch-on-theOrontes [Excavation Reports]. Princeton, NJ: Princeton University Press.

Ephesus Foundation. "Excavation History.” www.ephesus-foundation.org/about-ephesusexcavation-history.aspx (Accessed $7^{\text {th }}$ November 2012).

Erickson, Kyle \& Nicholas L. Wright. 2011. "The 'Royal Archer' and Apollo in the East: Greco-Persian Iconography in the Seleukid Empire" in Proceedings of the XIV ${ }^{\text {th }}$ International Numismatic Conference, edited by N. Holmes. Glasgow: International Numismatic Council: 1.163-168.

Erskine, Andrew. "The Romans as Common Benefactors," Historia: Zeitschrift für Alte Geschichte 43(1): 70-87.

Ferguson, William Scott. 1911. Hellenistic Athens: An Historical Essay. London: Macmillan.

Finkel I. \& R.J. van der Spek. Babylonian Chronicles of the Hellenistic Period. Forthcoming. www.livius.org/cg-cm/chronicles/chron00.html (BCHP).

Finley, M. I. 1976. "The Freedom of the Citizen in the Greek World" Talanta 7: 1-23.

Gera, Dov \& Wayne Horowitz. 1997. "Antiochos IV in Life \& Death: Evidence from the Babylonian Astronomical Diaries." Journal of the American Oriental Society 117(2): 240-252.

Giovannini, Adalberto. 1993. "Greek Cities and Greek Commonwealth" in Images \& Ideologies: Self-Definition in the Hellenistic World, edited by Anthony W. Bulloch, Erich S. Gruen, A.A. Long \& Andrew Stuart. Berkeley, CA: University of California Press: 265-286.

Glowacki, Kevin. 2003. "A Personification of Demos on a New Attic Document Relief." Hesperia 72(4): 447-466.

Grainger, John D. 1990a. The Cities of Seleukid Syria. Oxford: Clarendon Press.

1990b. Seleukos Nikator: Constructing a Hellenistic Kingdom. London: Routledge. 
1997. A Seleukid Prosopography and Gazetter. Leiden: Brill.

- 2002. The Roman War of Antiochos the Great. Leiden: Brill.

. 2010. The Syrian Wars. Leiden: Brill.

Grant, Michael. 1982. From Alexander to Cleopatra: The Hellenistic World. New York, NY: Charles Scribner's Sons.

Grayson, A.K. (1975) Assyrian and Babylonian Chronicles. Locust Valley, NY: J.J. Augustin.

Green, Peter. 2007. The Hellenistic Age: A Short History. New York, NY: Modern Library.

Griffith, G.T. 1935. The Mercenaries of the Hellenistic World. Cambridge: Cambridge University Press.

Gruen, Erich S. 1993. "Hellenism and Persecution: Antiochos IV and the Jews" in Hellenistic History \& Culture, edited by Peter Green. Berkeley, CA: University of California Press: 228-264.

Habicht, Christian. 1976. "Royal Documents in Maccabees II" Harvard Studies in Classical Philology 80: 1-18.

Hadley, Robert A. 1978. "The Foundation Date of Seleucia-on-the-Tigris." Historia: Zeitschrift für Alte Geschichte, 27(1): 228-230.

Hammond, Mason. 1951. City-State \& World-State in Greek \& Roman Political Theory until Augustus. Cambridge, MA: Harvard University Press.

Hammond, N.G.L. 1972, 1979, 1988. A History of Macedonia. Oxford: Oxford University Press.

. 1993. The Macedonian State: Origins, Institutions, and History. Oxford: Oxford University Press.

. 1993. "The Macedonian Imprint on the Hellenistic World," in Hellenistic History \& Culture, Peter Green. Berkeley, CA: University of California Press.

- 1999. "The Roles of the Epistates in Macedonian Contexts." The Annual of the British School at Athens 94: 369-375.

Hansen, Mogens Herman. 1995. “The 'Autonomous City-State': Ancient Fact or Modern Fiction?” Historia Einzelschriften 95: 21-44.

1996. "City Ethnics as Evidence for Polis Identity" in More Studies in the Ancient Greek Polis, edited by Mogens Herman Hansen \& Kurt Raaflaub (eds.). Stuttgart: Franz Steiner Verlag: 169-196.

2000. "A Summary of the Use of the Word Polis in Archaic and Classical Sources" in Further Studies in the Ancient Greek Polis, edited by P. Flensted-Jensen. Stuttgart: Franz Steiner Verlag: 173-215. 
2006. Polis: An Introduction to the Ancient Greek City-State. Oxford: Oxford University Press.

Hatzopoulos, M. B. 1996. Macedonian Institutions under the kings: A Historical and

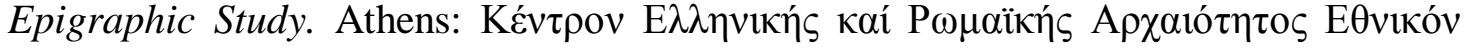

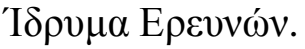

Heckel, Waldemar. 2002. "The Politics of Distrust: Alexander and his Successors" in The Hellenistic World: New Perspectives, edited by Ogden, Daniel. Swansea: The Classical Press of Wales: 81-96.

Herman, G. 1982. "The "Friends" of the Early Hellenistic Rulers." Talanta 12/13: 103149.

Heuchert, Volker. 2005. "The Chronological Development of Roman Provincial Coin Iconography," in Coinage \& Identity in the Roman Provinces, edited by Christopher Howgego, Volker Heuchert, \& Andrew Burnett. Oxford: Oxford University Press: 2956.

Heuss, Alfred. 1937. Stadt und Herrscher des Hellenismus in ihren Staats: und völkerrechtlichen Beziehungen. Leipzig: Dieterich.

Hitti, Philip K. 1951. History of Syria: Including Lebanon and Palestine. London: MacMillan \& Co.

Holleaux, Maurice. 1933. "Une inscription de Séleucie-de-Pierie." Bulletin de Correspondance Hellénique 57: 6-67.

Holt, Frank Lee. 1999. Thundering Zeus: The Making of Hellenistic Bactria. Berkeley, CA: University of California Press.

Hoover, Oliver D. 2001. "Quasi-Municipal Coinage in Seleucid Apamea: Countermarks and Counterrevolution." Schweizerische Numismatische Rundschau, 80: 1-14.

- "A Revised Chronology for the Late Seleucids at Antioch (121/0-64 BC)." Historia: Zeitschrift für Alte Geschichte 56(3): 280-301.

Hopkins, Clark. 1972. Topography \& Architecture of Seleucia on the Tigris. Ann Arbor, MI: University of Michigan Press.

Horster, Marietta. 2012. "Priests, Priesthoods, Cult Personnel: Traditional \& New Approaches" in Civic Priest Cult Personnel in Athens from the Hellenistic Period to Late Antiquity, edited by Marietta Horster \& Anja Klöcher. Berlin: Walter de Gruyter: $5-26$.

Houghton, Arthur. 1999. "The Early Seleucid Mint of Laodikeia ad Mare (c.300-246 BC)" in Travaux de Numismatique Grecque offerts a Georges le Rider, edited by Michel Amandry, Silvia Hurter \& Denyse Bérend. London: Spink: 169-184.

Houghton, Arthur \& Catharine Lorber. 2002. Seleucid Coins: A Comprehensive Guide. New York, NY: American Numismatic Society. (SC)

Howgego, Christopher. 1995. Ancient History from Coins. London: Routledge. 
Ikida, Yutaka. 1979. "Royal Cities \& Fortified Cities.” Iraq 41(1): 75-87.

Invernizzi, Antonio. 1993. "Seleucia on the Tigris: Centre and Periphery in Seleucid Asia" in Centre \& Periphery in the Hellenistic World, edited by Per Bilde et al. Aarhus: Aarhus University Press: 230-250.

Iossif, Panagiotis P. 2011. "Apollo Toxotes \& the Seleukids: Comme un air de famille," in More than Men, Less than Gods: Studies on Royal Cult \& Imperial Worship, edited by Panagiotis Iossif, Andrzej Chanowski \& Catharine Lorber. Leuven: Peeters: 229292.

Isaac, Benjamin. 1991. "A Seleucid Incription from Jamnia-on-the-Sea: Antiochos V Eupator and the Sidonians." Israel Exploration Journal 41(1/3): 132-144.

Jeffreys, Elizabeth, Michael Jeffreys, Roger Scott et al. 1986. The Chronicle of John Malalas. Melbourne, VIC: Australian Association for Byzantine Studies.

Johnson, Jotham. 1932. Dura Studies: A Thesis in Greek. Unpublished PhD diss., University of Pennsylvania.

Jones, A.H.M. 1940. The Greek City: From Alexander to Justinian. Oxford: Clarendon Press.

Jones, Christopher P. 1999. Kinship Diplomacy in the Ancient World. Cambridge, MA: Harvard University Press

Jones, Christopher P. \& Christian Habicht, 1989. "A Hellenistic Inscription from Arsinoe in Cilicia." Phoenix 43(4): 317-346.

Jouget, Pierre. 1928. Macedonian Imperialism and the Hellenization of the East. London: Kegan Paul.

Kallet-Marx, Lisa. 1994. "Money Talks: Rhetor, Demos, and the Resources of the Athenian Empire" in Ritual, finance, politics: Athenian democratic accounts presented to David Lewis, edited by Robin Osborne \& Simon Hornblower.Oxford: Clarendon Press:227-252.

Kindler, Arie. 1978. "Akko, A City of Many Names." Bulletin of the American Schools of Oriental Research 231: 51-55.

Koenen, Ludwig. 1993. "The Ptolemaic King as a Religious Figure" Images \& Ideologies: Self-Definition in the Hellenistic World, edited by Anthony W. Bulloch, Erich S. Gruen, A.A. Long \& Andrew Stuart. Berkeley, CA: University of California Press: 25115.

Kitt, Brian. 2002a. "Seleucid Bronze Coinage: Denominations \& Metrology," in Seleucid Coins: A Comprehensive Guide, edited by Arthur Houghton \& Catharine Lorber. New York, NY: American Numismatic Society: 1.2.1-36.

. 2002b. "Countermarks on Seleucid Bronze Coins" in Seleucid Coins: A Comprehensive Guide, edited by Arthur Houghton \& Catharine Lorber. New York, NY: American Numismatic Society: 1.2.37-72 
Kuhrt, Amélie. 1996. "The Seleucid Kings and Babylonia: New Perspectives on the Seleucid Realm in the East" in Aspects of Hellenistic Kingship, edited by Per Bilde et al.. Aarhus: Aarhus University Press: 41-54.

Kuhrt, Amélie \& Susan Sherwin-White. 1991. "Aspects of Seleucid Royal Ideology: The Cylinder of Antiochus I from Borsippa.” Journal of Hellenic Studies 111: 71-86.

Kutbay, Bonnie Lea. 1998. Palaces \& Large Residences of the Hellenistic Age.Lampeter: Edwin Mellen Press.

Lambert, Stephen.D. 2000. "The Greek Inscriptions on Stone in the Collection of the British School at Athens." The Annual of the British School at Athens 95: 485-516.

. 2012. "The Social Construction of Priests and Priestesses in Athenian Honorific Decrees from the Fourth Century BC to the Augustan Period" in Civic Priests: Cult Personnel in Athens from the Hellenistic Period to Late Antiquity, edited by Horster, Marietta \& Anja Klöckner. Berlin: Walter de Gruyter: 67 - 134.

Lang, David Marshall. 1970. Armenia: Cradle of Civilization. London: George Allen \& Unwin.

1983. "Iran, Armenia \& Georgia" in The Cambridge History of Iran, Vol.3: The Seleucid, Parthian and Sasanid Periods, edited by Ehsan Yarshater. Cambridge: Cambridge University Press: 505-536.

Larsen, J.A.O. 1968. Greek Federal States: Their Institutions and History. Oxford: Clarendon Press.

Lendering, Jona, R.J. Van der Spek, M. Stolper, Mordechai Cogan. 2010. "Cyrus Cylinder (2)." Revised. www.livius.org/ct-cz/cyrus_I/cyrus_cylinder2.html (Accessed $26^{\text {th }}$ February 2012).

Liddell, Henry George \& Robert Scott. 1968. A Greek-English Lexicon. $9^{\text {th }}$ Ed, revised by Henry Stuart Jones. Oxford: Clarendon Press.

Linssen, Marc J.H. 2004. The Cults of Uruk \& Babylon: The Temple Ritual Texts as Evidence for Hellenistic Cult Practice. Leiden: Brill.

Llewellyn-Jones, Lloyd \& Stephanie Winder. 2011. “A Key to Berenike's Lock? The Hathoric Model of Queenship in Early Ptolemaic Egypt" in Creating a Hellenistic World, edited by Andrew Erskine \& Lloyd Llewellyn-Jones. Swansea, Wales: The Classical Press of Wales: 247-269.

Lloyd, Alan B. 1982. "Nationalist Propaganda in Ptolemaic Egypt." Historia : Zeitschrift für Alte Geschichte 31(1): 33-55.

. 2002. "The Egyptian Elite in the Early Ptolemaic Period: Some Hieroglyphic Evidence" in The Hellenistic World: New Perspectives, edited by Daniel Ogden. Swansea: The Classical Press of Wales: 117-136.

Low, Polly. 2005. "Looking for the Language of Athenian Imperialism." The Journal of Hellenic Studies 125: 93-111.

Lund, Helen S. 1992. Lysimachus: A Study in Early Hellenistic Kingship. London: Routledge 
Ma, John. 1999. Antiochos III and the Cities of Western Asia Minor. Oxford: Oxford University Press.

2000a. "Fighting Poleis of the Hellenistic World" in War and Violence in Ancient Greece, edited by Hans Van Wees. London: Duckworth \& the Classical Press of Wales: 337-376.

2000b. "Seleukids \& Speech Acts: Performative Utterances, Legitimacy, and Negotiation in the World of the Maccabees." Scripta Classica Israelica 19: 71-112.

2003. "Kings" in A Companion to the Hellenistic World, edited by Andrew Erskine. Malden, MA: Blackwell Publishing: 177-195.

MacLaren, Malcolm. 1941. "Tyranny" in The Greek Political Experience: Studies in Honor of William Kelly Prentice [no editor]. New York, NY: Russell \& Russell: 78-92.

Mairs, Rachel. Forthcoming. "The 'Temple with Indented Niches' at Ai Khanoum: Ethnic and Civic Identity in Hellenistic Bactria" in Cults, Creeds and Contests in the PostClassical City, edited by Richard Alston \& Onno van Nijf. Leuven: Peeters. www.academia.edu/209809 (Accessed 15 ${ }^{\text {th }}$ December 2012).

Manicas, Peter T. 1982. "War, Stasis, \& Greek Political Thought." Comparative Studies in Society \& History 24(4): 673-688.

Martin, Thomas R. 1985. Sovereignty \& Coinage in Classical Greece. Princeton, NJ: Princeton University Press.

Mastrocinque, Attilio. 1980-1981. "Storia e monetazione di Mileto all'epoca dei Diadochi” Annali dell'Istituto Italiano di Numismatica 27-28: 61-78.

McDowell, Robert G. 1972. "The History of Seleucia from Classical Sources," in Topography \& Architecture of Seleucia on the Tigris, edited by Clark Hopkins. Ann Arbor, MI: University of Michigan Press: 149-163.

McEvedy, Colin. 2011. Cities of the Classical World: An Atlas and Gazetteer of 120 Centuries of Ancient Civilization. Bristol: Allen Lane.

McEwan, Gilbert. 1988. "Babylonia in the Hellenistic Period." Klio 70(2): 412-421.

McLean, B.H. 2002. An Introduction to Greek Epigraphy of the Hellenistic and Roman Periods from Alexander the Great Down to the Reign of Constantine (323 B.C.-A.D. 337). Ann Arbor, MI: University of Michigan Press.

McNicoll, A.W. 1997. Hellenistic Fortifications: from the Aegean to the Euphrates, edited by N.P. Milner. Oxford: Clarendon Press.

Meister, K. 1984. "Agathokles" in The Cambridge Ancient History $2^{\text {nd }}$ Ed. Vol VII Part I: The Hellenistic World, edited by Walbank, F.W., A.E. Astin, M.W. Frederiksen \& R.M. Ogilvie. Cambridge: Cambridge University Press: 384-411.

Melville-Jones, J.R. 1972. "Epigraphical Notes on Hellenistic Bronze Coinage." The Numismatic Chronicle $7^{\text {th }}$ S. 12: 39-43. 
Merker, Irwin. 1970. "The Ptolemaic Officials and the League of the Islanders" Historia: Zeitschrift für Alte Geschichte 19(2): 141-160.

Millar, Fergus. 1998. "Looking East from the Classical World: Colonialism, Culture and Trade from Alexander the Great to Shapur I" The International History Review 20(3): 507-531.

Mitchell, Lynette G. 1997. Greeks Bearing Gifts: The Public Use of Private Relationships in the Greek World, 435-323 BC. Cambridge: Cambridge University Press.

Momigliano, Arnaldo. 1975. "The Second Book of Maccabees" Classical Philology 70(2): 81-88.

Morel, Jean-Paul. 2006. "Phocaean Colonisation" in Greek Colonisation: An Account of Greek Colonies \& Other Settlements Overseas, edited by Gocha R. Tsetskhladze. Leiden: Brill: 1.358-428.

Morgan, M. Gwyn. 1990. "The Perils of Schematism: Polybius, Antiochus Epiphanes and the 'Day of Eleusis'." Historia: Zeitschrift für Alte Geschichte 39(1): 37-76.

1993. in Hellenistic History \& Culture, edited by Peter Green. Berkeley, CA: University of California Press: 264-269.

Mørkholm, Otto. 1961. "The Municipal Coinages with Portrait of Antiochus IV of Syria" in Congresso Internazionale di Numismatica Roma 11-16 Settembre 1961, edited by Commission Internationale de Numismatique. Rome: Istituto Italiano di Numismatica: 63-68.

1966. Antiochus IV of Syria. Copenhagen: Gyldendal.

. 1984. "The Monetary System in the Seleucid Empire after 187 BC" in Ancient Coins of the Graeco-Roman World: The Nickle Numismatic Papers, edited by Waldemar Heckel \& Richard Sullivan. Waterloo, ON: Wilfred Lavrier University Press: 93-114.

1991. Early Hellenistic Coinage: From the Accession of Alexander to the Peace of Apamea (336-186 BC). Cambridge: Cambridge University Press.

Mossman, Judith. 2010. “A Life Unparalleled: Artaxerxes," in Plutarch's Lives: Parallelism \& Purpose, Noreen Humble. Swansea: The Classical Press of Wales: 145168.

Murray, Oswyn. 2000. "What is Greek about the Polis?" in Polis and Politics: Studies in Ancient Greek History, edited by Flensted-Jensen, P, T.H. Nielsen \& L Rubinstein (eds). Copenhagen: Museum Tusculum Press: 231-248.

Musti, Domenico. 1966. "Lo Stato dei Seleucidi: Dinastia Popoli città de Seleuco I ad Antioco III” Studi Classici e Orientali 15: 61-197.

1984. "Syria and the East" in The Cambridge Ancient History $2^{\text {nd }}$ Ed. Vol VII Part I: The Hellenistic World, edited by F.W. Walbank, A.E. Astin, M.W. Frederiksen \& R.M. Ogilvie. Cambridge: Cambridge University Press: 175-220. 
Nawotka, Krzysztof. 1999. Boule and Demos in Miletus and Its Pontic Colonies from Classical Age Until Third Century A.D. Wrocław: Zakład Narodowy im. Ossolińskich.

Nevett, Lisa C. 1999. House and Society in the Ancient Greek World. Cambridge: Cambridge University Press.

Nielsen, Inge. 1996. "Oriental Models for Hellenistic Palaces?” in Basileia: Die Paläste der hellenistischen Könige, edited by W. Hoepfner and G. Brands. Mainz: Verlag Philipp von Zabern: 209-212.

Nixon, C.E.V. 2002. "The Coins" in Jebel Khalid on the Euphrates: Report on Excavations 1986-1996. Volume I, edited by G.W. Clark et al. Sydney, NSW: Meditarch: 293-335.

Ogden, Daniel. 1999. Polygamy, Prostitutes and Death: The Hellenistic Dynasties. Swansea: The Classical Press of Wales.

Oliver, G. 2001. "The Politics of Coinage: Athens and Antigonus Gonatas" in Money and Its Uses in the Ancient Greek World, edited by Meadows, Andrew \& Kirsty Shipton. Oxford: Oxford University Press: 35-72.

O'Neil, J.L. 2000. "Royal Authority and City Law under Alexander and his Hellenistic Successors.” Classical Quarterly 50(2): 424-431

Ostwald, Martin. 1982. Autonomia: Its Genesis \& Early History. Scholars’ Press.

. 2000. "Oligarchy and Oligarchs in Ancient Greece" in Polis and Politics: Studies in Ancient Greek History, edited by Flensted-Jensen, P, T.H. Nielsen \& L Rubinstein. Copenhagen: Museum Tusculum Press: 385-396.

Owens, E.J. 1991. The City in the Greek \& Roman World. London: Routledge.

Paltiel, Eliezer. 1979. "The Treaty of Apamea \& the Later Seleucids." Antichthon 13: 3041.

Parke, H.W. 1985. The Oracles of Apollo in Asia Minor. London: Croom Helm.

Pelling, Christopher. 2011. Plutarch \& History. Swansea: The Classical Press of Wales.

Perkins, Ann. 1959. The Excavations at Dura-Europos: Final Report V Part I: Parchments and Papyri. New Haven, CT: Yale University Press. (P.Dura)

Perlman, S. 1985. "Greek Diplomatic Tradition \& the Corinthian League of Philip of Macedon." Historia: Zeitschrift für Alte Geschichte 34(2): 153-174.

Pollitt, J.J. 1986. Art in the Hellenistic Age. Cambridge: Cambridge University Press.

Potter, D. 2003. "Hellenistic Religion" in A Companion to the Hellenistic World, Andrew Erskine. Malden, MA: Blackwell Publishing: 407-430.

Price, S.R.F. 1984. Rituals \& Power: The Roman Imperial Cult in Asia Minor. Cambridge: Cambridge University Press.

Raaflaub, Kurt. 2004. The Discovery of Freedom in Ancient Greece, translated by Renate Franciscono. Chicago, IL: University of Chicago Press. 
Ragette, Friedrich. 1980. Baalbek. Park Ridge, NJ: Noyes Press.

Redgate, Anne Elizabeth. 1998. The Armenians. Oxford: Blackwell Publishers.

Rhodes, P.J. \& David M. Lewis. 1997. The Decrees of the Greek States. Oxford: Clarendon Press.

Rigsby, Kent J. 1980. "Seleucid Notes." Transactions of the American Philological Association (1974-) 110: 233-254.

-1996. Asylia: Territorial Inviolability in the Hellenistic World. Berkeley, CA: University of California Press.

Roebuck, Carl. 1959. Ionian Trade and Colonization. New York, NY: Archaeological Institute of America.

Roueché, Charlotte \& S.M. Sherwin-White. 1985. "Some Aspects of the Seleucid Empire: The Greek Inscriptions from Failaka, in the Arabian Gulf." Chiron 15: 1-39.

Roussel, Pierre. 1942-1943. "Décret des Péliganes de Laodicée-sur-Mer." Syria 23(1/2): 21-32.

Rostovtzeff, M.I. 1932. Seleucid Babylonia: Bullae and Seals of Clay with Greek Inscriptions. New Haven, CT: Yale University Press.

. 1935. “ПРОГОNOI.” Journal of Hellenic Studies 55(1): 56-66.

. 1941. The Social \& Economic History of the Hellenistic World. Oxford: Clarendon Press.

Rostovtzeff, M. and Welles, Charles Bradford. 1931. "A Parchment Contract of Loan from Dura-Europus on the Euphrates." Yale Classical Studies 2: 3-78.

Runciman, W.G. 1990. "Doomed to Extinction: The Polis as an Evolutionary Dead-End" in The Greek City: From Homer to Alexander, edited by Murray, Oswin \& Simon Price. Oxford: Clarendon Press: 347-367

Sachs, Abraham J. \& Hermann Hunger. 1988. Astronomical Diaries and Related Texts from Babylonia. Vienna: Verlag der Österreichischen.

Sarkisian, G. Kh. 1969. "City Land in Seleukid Babylonia," translated by G.M. Sergheyev in Ancient Mesopotamia: Socio-Economic History: A Collection of Studies by Soviet Scholars, edited by I.M. Diankonoff. Moscow: "Nauka" Publishing House: 312-331.

Schaper, Joachim. 1995. "The Jerusalem Temple as an Instrument of the Achaemenid Fiscal Administration" Vetes Testamentum 45(4): 528-539.

Seyrig, Henri. 1940. "Scène Historique sur en Chapiteau de Musée de Beyrouth Historique sur en Chapiteau du Musée de Beyrouth" Revue des Etudes Anciennes 42: 340-344.

311. 
Sherk, Robert K. 1991. "The Eponymous Officials of Greek Cities IV: The Register: Part III: Thrace, Black Sea Area, Asia Minor." Zeitschrift für Papyrologie und Epigraphik 88: $225-260$.

. 1992. "The Eponymous Officials of Greek Cities IV: The Register: Part III: Thrace, Black Sea Area, Asia Minor (Continued)." Zeitschrift für Papyrologie und Epigraphik 93: 223-272.

Sherwin-White, Adrian N. 1994. "Lucullus, Pompey \& the East" in Cambridge Ancient History, Vol.9 Prt.1: The Last Age of the Roman Republic, 146-43 BC. $2^{\text {nd }}$ Ed, edited by J.A. Crook, Andrew Lintott \& Elizabeth Rawson. Cambridge: Cambridge University Press: 229-273.

Sherwin-White, Susan M. 1982. "A Greek Ostrakon from Babylon of the Early Third Century B.C." Zeitschrift für Papyrologie und Epigraphik 47: 51-70.

. 1983. "Babylonian Chronicle Fragments as a Source for Seleucid History." Journal of Near Eastern Studies 42(4): 265-270.

1984. "Shami, the Seleukids and Dynastic Cult: A Note." Iran 22: 160-161.

1987. "Seleucid Babylonia: A Case Study for the Installation and Development of Greek Rule" in Hellenism in the East, edited by Amélie Kuhrt \& Susan SherwinWhite. Berkeley, CA: University of California Press: 1-31.

Sherwin-White, Susan \& Amélie Kuhrt. 1993. From Samarkand to Sardis: A New Approach to the Seleukid Empire. Berkeley, CA: University of California Press.

Shipley, Graham. 2000. The Greek World After Alexander 323 - 30. London: Routledge.

Siani-Davies, Mary. 1997. "Ptolemy XII Auletes \& the Romans." Historia: Zeitschrift für Alte Geschichte 46(3): 306-340.

Smith, R.R.R. 1988. Hellenistic Royal Portraits. Oxford: Oxford University Press.

Sosin, Joshua D. 2005. "Unwelcome Dedications: Public Law and Private Religion in Hellenistic Laodicea by the Sea," The Classical Quarterly, N.S. 55(1): 130-139.

Stansbury-O'Donnell, Mark D. 1994. "Reflections of the Tyche of Antioch in Literary Sources and on Coins," Yale University Art Gallery Bulletin 54(2): 50-63.

Starr, Chester G. 1975. "Greeks \& Persians in the Fourth Century B.C.: A Study in Cultural Contacts before Alexander." Iranica Antiqua 11: 39-99.

Steele, James. 1992. Hellenistic Architecture in Asia Minor. London: Academy Editions.

Stinespring, William F. (Trans.). 1932. The Description of Antioch in Codex Vaticanus Arabicus 286. PhD diss., Yale University.

Stronach, David. 2012. "Builders for the Ages: Elamites, Medes, Achaimenids \& Parthians (1500 BC-224 AD)" in Ancient Iran from the Air, edited by David Stronach \& Ali Mousavi. Darmstadt: Verlag Philipp von Zabern: 39-75.

Swain, S.C.R. 1992. "Plutarch's Characterization of Lucullus." Rheinisches Museum für Philologie, Neue Folge 135(3/4): 307-316. 
Tatum, W. Jeffrey. 2010. "Why Parallel Lives?" in Plutarch's Lives: Parallelism \& Purpose, edited by Noreen Humble. Swansea: The Classical Press of Wales: 1-22.

Thurn, Ioannes. 2000. Ioannis Malalae Chronographia. Berlin: Walter de Gruyter.

Treadgold, Warren. 2007. "The Byzantine World Histories of John Malalas and Eustathius of Epiphania." The International History Review 29(4): 709-741.

van Bremen, Riet. 1996. The Limits of Participation: Women \& Civic Life in the Greek East in the Hellenistic \& Roman Periods. Amsterdam: JC Gieben.

Van Dam, Raymond. 2010. Rome and Constantinople: Rewriting Roman History During Late Antiquity. Waco, TX: Baylor University Press.

Van De Mieroop, Marc. 1997. The Ancient Mesopotamian City. Oxford: Oxford University Press.

van der Spek, R.J. 1987. "The Babylonian City" in Hellenism in the East, edited by Amélie Kuhrt \& Susan Sherwin-White. Berkeley, CA: University of California Press: 57-74.

1993. "The Astronomical Diaries as a Source for Achaemenid and Seleukid History." Bibliotheca Orientalis 50: 91-101.

Walbank, F.W. 1957, 1967 \& 1979. A Historical Commentary on Polybius. Oxford: Clarendon Press.

. 1984a. "Sources for the Period," in Cambridge Ancient History, Vol.7 Prt.1: The Hellenistic World. $2^{\text {nd }}$ Ed., edited by F.W. Walbank, A.E. Astin, M.W. Frederiksen \& R.M. Ogilvie. Cambridge: Cambridge University Press: 1-22.

1984b. "Monarchies and Monarchic Ideas," in Cambridge Ancient History, Vol.7 Prt.1: The Hellenistic World. $2^{\text {nd }}$ Ed., edited by F.W. Walbank, A.E. Astin, M.W. Frederiksen \& R.M. Ogilvie. Cambridge: Cambridge University Press: 62-100.

University Press.

. 1993. "Response to Part One" in Images \& Ideologies: Self-Definition in the Hellenistic World, edited by Anthony Bulloch, Erich Gruen, A.A. Long \& Andrew Stuart. Berkeley, CA: University of California Press: 116-126.

. 2000. "Hellenes and Achaians: "Greek Nationality Revisited"” in Further Studies in the Ancient Greek Polis, edited by P. Flensted-Jensen. Stuttgard: Franz Steiner Verlag: 19-33.

Welles, C. Bradford. 1966. Royal Correspondence in the Hellenistic Period. Rome: "L'Erma" di Bretschneider.

Wiesehöfer, Josef. 2011. "Fratarakā Rule in Early Seleucid Persis: A New Appraisal" in Creating a Hellenistic World, edited by Andrew Erskine \& Lloyd Llewellyn-Jones. Swansea, Wales: The Classical Press of Wales: 107-122. 
Will, Edouard. 1982. Histoire politique du monde hellénistique (323-30 av JC). $2^{\text {nd }}$ Ed. Nancy: Presses universitaires de Nancy.

. 1984a. "The Succession to Alexander" in Cambridge Ancient History, Vol.7 Prt.1: The Hellenistic World. $2^{\text {nd }}$ Ed., edited by F.W. Walbank, A.E. Astin, M.W. Frederiksen \& R.M. Ogilvie. Cambridge: Cambridge University Press: 26-61.

. 1984b. "The Formation of the Hellenistic Kingdoms" in Cambridge Ancient History,' 7 Part 1: The Hellenistic World. $2^{\text {nd }}$ Ed., edited by F.W. Walbank, A.E. Astin, M.W. Frederiksen \& R.M. Ogilvie. Cambridge: Cambridge University Press: 101-117.

Woodhead, A. G. 1967. The Study of Greek Inscriptions. Cambridge: Cambridge University Press.

Wörrle, Michael. 1975. "Epigraphische Forschungen zur Geschichte Lykiens I.” Chiron 5: 59-87.

Worthington, Ian. 2011-. Brill's New Jacoby. Leiden: Brill. www.brill.com/publications/ online-resources/jacoby-online.

Wright, Nicholas L. 2009/2010. "Non-Greek Religious Iconography on the Coinage of Seleucid Syria." Mediterranean Archaeology 22/23: 193-206.

- 2011. "Iconography of Succession under the Late Seleukids" in Selections from the Colin E. Pitchfork Collection, edited by Nicholas L. Wright. Sydney, NSW: The Australian Centre for Ancient Numismatic Studies: 41-46.

Wycherley, R.E. 1951. "Hellenistic Cities.” The Town Planning Review 22(3): 177-205. 1962. How the Greeks Built Cities. London: Macmillan.

Zahle, Jan. 1990. "Religious Motifs on Seleucid Coins," in Religion \& Religious Practice in the Seleucid Kingdom, edited by Per Bilde, Troels Engberg, Lise Hannestad, \& Jan Zahle. Aarhus: Aarhus University Press. 